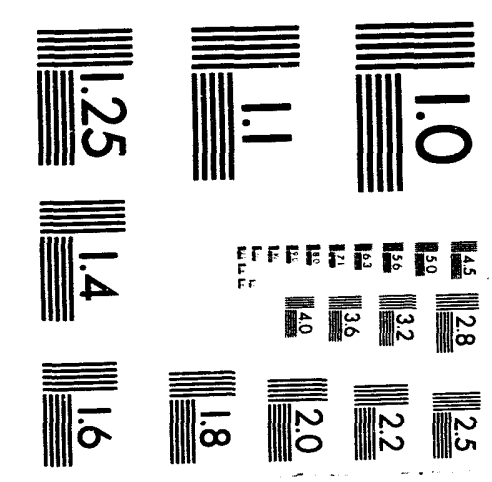




$$
\stackrel{\vec{o}}{\omega}
$$




\section{Site Environmental Report for 1992}

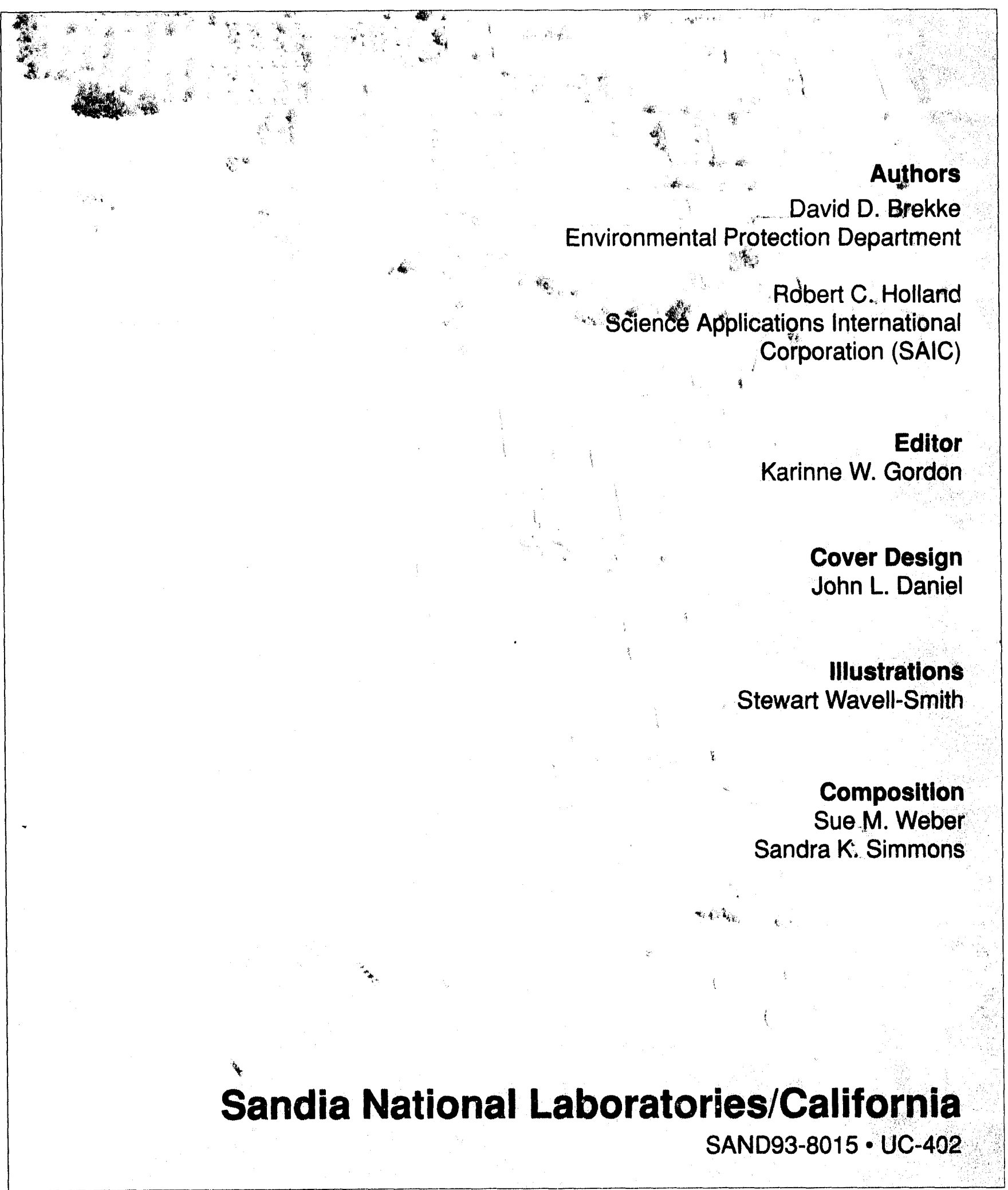




\section{Acknowledgments}

Listed below are the Sandia employees responsible for specific programs in the Environmental Protection Department. These people contributed to the respective sections of this report.

Environmental Monitoring Program

Environmental Restoration Program

Hazardous Waste Management Program

National Environmental Policy Act

Environmental Technology

Air Quality

Waste Minimization and

Pollution Prevention
David D. Brekke

Alexandra T. Leo

Kim K. Shepodd

Sheryl L. Buck

Mark E. Brynildson

Laura Santos

Alice Johnson-Duarte

In addition, Ken Nunez served as lead field technician and was responsible for collecting many of the SNL/California environmental samples.

The manager of the Environmental Protection Department, Don Nissen, provided support and encouragement throughout the reporting process. Kirk Hilbelink, with Science Applications International Corporation (SAIC), made significant technical contributions to this report. The authors would also like to acknowledge the following individuals for their significant contributions: Charles Clay, Toff Garcia, and Albert Sandoval.

For further information about this report, contact:

Sandia National Laboratories

Public Information Office

P. O. Box 969

Livermore, CA 94551-0969

Attention: Barry Schrader

Phone: (510) 294-2447 
The U.S. Department of Energy (DOE) Order 5400.1, General Environmental Protection Programs, establishes requirements for environmental protection programs at DOE sites, including Sandia National Laboratories (SNL). These programs ensure that DOE operations comply with Federal, State, and local environmental laws and regulations, as well as DOE Orders and policies. To comply with DOE Order 5400.1, SNL/California has prepared the Environmental Protection Implementation Plan. This document provides the framework for SNL/California to implement DOE's environmental protection goals and comply with environmental regulations.

To verify effective protection of the environment, SNL/California maintains an extensive effluent monitoring and environmental surveillance program. This program collects the information necessary to assess how effective pollution control measures are and to characterize the site's impact on the environment. The monitoring program routinely measures the levels of pollutants and radioactive material around the Sandia site and surrounding area. Much of the offsite environmental monitoring data in this report were collected by Lawrence Livermore National Laboratory (LLNL), which monitors outlying areas (far-field) for both facilities. The SNL/California Environmental Monitoring Plan identifies the operations and emissions at the site and describes the effluent monitoring and environmental surveillance program and activities. These programs and activities are in place to protect the public and the environment. The Plan describes exposure pathways (potential routes of human exposure to pollutants), sampling and analysis proce- dures, radiation dose assessment methods, and quality assurance activities.

The SNL/California Environmenial Protection Department is responsible for all environmental programs and activities, including reporting requirements. Environmental Protection staff maintain various documents describing specific program areas. These documents are referenced in this report, as appropriate.

The SNL/California Environmental Protection Department prepares the Site Environmental Report annually to meet the reporting requirements of DOE and other regulatory agencies. It describes the results of SNL/California's environmental protection activities during the calendar year. It also summarizes environmental monitoring data and highlights major environmental programs. It evaluates SNL/California's environmental management performance and documents the site's regulatory compliance status.

Most importantly, the Site Environmental Report serves the needs of the public. It is a key element in our communication with the local community. For this reason, the report contains two summary chapters: the Executive Summary and the Compliance Summary, which highlight and interpret environmental findings and regulatory compliance for the year. These summaries are written for the layperson and use a minimum of technical terminology. However, we have also included an extensive glossary in the back of the report. It defines acronyms, abbreviations, and technical terms. It also describes radiological nomenclat ture and conversion information for units used in the report. 
The body of the report is a comprehensive description of environmental activities. It provides substantial background information and covers all major environmental programs at SNL/California.

Since 1990, SNL/California has cooperated with the State of California to provide additional independent environmental surveillance around the DOE sites in Livermore. This effort (referred to as the "Agreement in Principle") allows the State Department of Health Services to monitor environmental activities at SNL/California and LLNL. The purpose of this agreement is to provide local citizens added assurance that their health and their environment are being adequately protected.

In October 1992, DOE adopted a public participation policy, which commits to pro- viding the public an opportunity to become involved in the decision-making process for environmental restoration and waste management activities. To implement this program, SNL/California is developing a formal public participation program. This program will help keep the local community informed of matters that affect them. It will help DOE address public values and concerns. As a good corporate citizen, SNL/California has a long-standing policy of openness with the local community, which has included public meetings, site tours, and informational bulletins. Our formal public participation program will further foster cooperative interaction with our neighbors.

This report is the result of a team effort among the various programs that make up the Environmental Protection Department at SNL/California. We in the Environmental Protection Department are committed to preserving the quality of our environment and to protecting public health. Furthermore, we consider the citizens of Livermore and the surrounding area to be our principal "customers" in this endeavor. Therefore, we strive to work in partnership with the local community. 
1 - Executive Summary ..................................................................................................1-1

Air Monitoring...............................................................................................................1

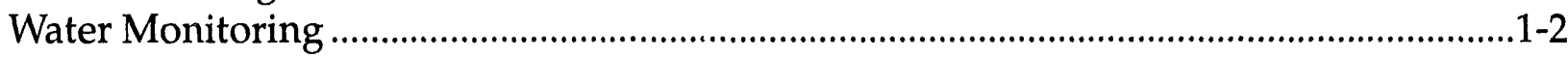

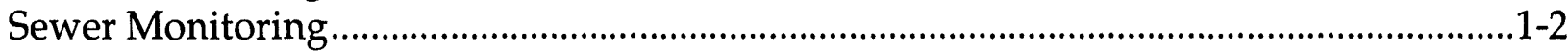

Soil Monitoring ..............................................................................................................1-3

Vegetation and Foodstuff Monitoring ................................................................................1-3

External Radiation Monitoring ………..............................................................................1-3

Radiation Impact to the Public ....................................................................................

Nonroutine Releases .........................................................................................................1-5

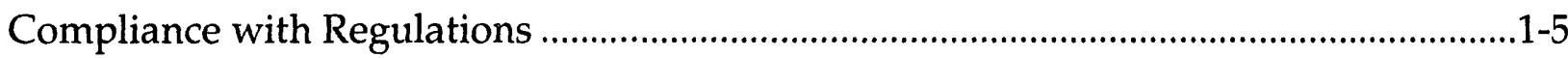

Environmental Monitoring Plan ......................................................................................1-6

2 - Introduction..................................................................................................................................2-1

Environment, Safety, and Health (ES\&H) Organization ........................................................ $2-1$

Self-Assessment Program.......................................................................................................2-2

Center for ES\&H and Facilities ..........................................................................................2-3

Environmental Protection Department ..................................................................................2-3

Environmental Monitoring Program................................................................................. $2-5$

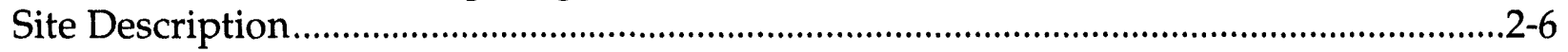

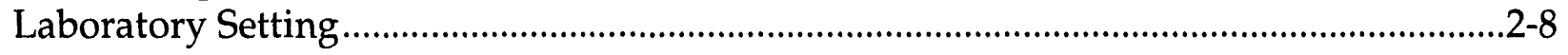

Annual Site Environmental Report...........................................................................2-11

3 - Compliance Summary ........................................................................................................................

Environmental Monitoring .................................................................................................

Environmental Programs Status ………..............................................................................

Current Issues and Actions...............................................................................................

Environmental Permits.........................................................................................

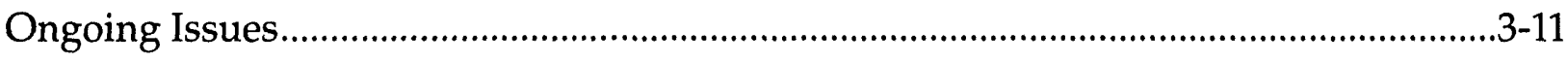

4 - Environmental Monitoring Program Information........................................................................4-1

Effluent Monitoring Results...............................................................................................4-1

Meteorological Monitoring Results ...................................................................................4-6

Environmental Surveillance Results...........................................................................4-7

5 - Environmental Impacts .............................................................................................................5-1

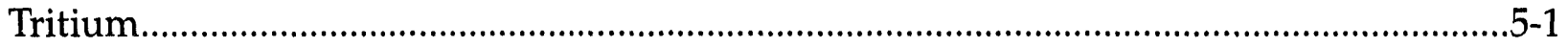

Modeling the Dispersion of Atmospheric Releases ..............................................................5-2

Perspectives on Radiation Exposures....................................................................................5-5 


\section{Contents}

6 - Environmental Program Information .....................................................................................6-1

Environmental Restoration Program..........................................................................6-1

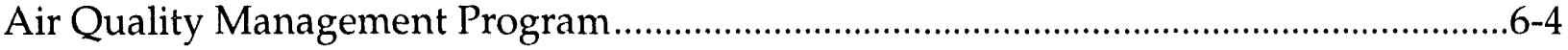

Wastewater Control Program ………..................................................................................6-5

Waste Management Programs ..........................................................................................6-7

Waste Minimization and Pollution Prevention Awareness.................................................6-8

Chemical Information System ........................................................................................6-13

Toxic Substance Control Act (TSCA) Compliance................................................................6-13

National Environmental Policy Act (NEPA) Compliance ..................................................6-14

Pollution Abatement Projects .......................................................................................6-15

7 - Groundwater Protection Program ................................................................................... 7-1

Subsurface Investigations ...............................................................................................

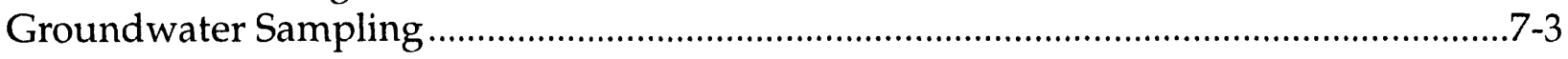

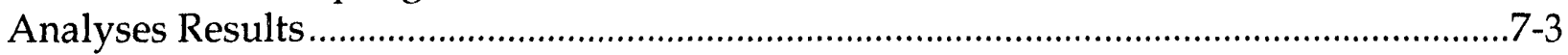

8 - Quality Assurance ...........................................................................................................

References ........................................................................................................................REF-1

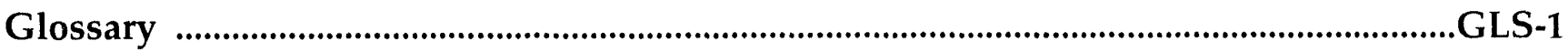

Appendices

A - Laboratory Procedures

B - Summary of Wastewater Discharge Regulations

C - Radiological Dose Assessment

D - Radiation Protection Standards

E - Environmental Monitoring Program

Quality Assurance Project Plan 
1-1 Annual airborne tritium discharges from SNL/California, 1987-92.....................1-2

1-2 Typical radiation doses received by the general public and the maximum contribution from SNL/California ....................................................1-5

2-1 Environment, safety, and health organizational chart as of December 1992 ...........2-2

2-2 Organizational structure of the Environmental Protection Department .................2-4

2-3 SNL/California in a regional setting .................................................................2-8

2-4 Groundwater contours at SNL/California ...........................................................2-10

2-5 Wind rose showing the average annual wind direction and speed during 1992...2-11

3-1 Status of SNL/California's Action Plan in response to the DOE

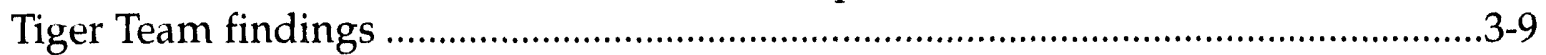

4-1 Tritium releases for both SNL/California and LLNL since 1982 „.......................4-1

4-2 SNL/California Liquid Effluent Control Systems (LECS) ......................................4-3

4-3 SNL/California sanitary sewer system ..........................................................4-5

4-4 Location of the SNL/California meteorological monitoring station .......................4-7

4-5 Wind rose showing the average annual wind direction and speed during 1992

4-6 SNL/California site perimeter ambient air monitoring locations ..........................4-9

4-7 Air sampling locations, Livermore Valley............................................................4-10

4-8 Highest annual average uranium concentration in air at the Livermore site perimeter (1987-92) .....................................................................4-11

4-9 Highest annual average tritium concentration in air (1987-92) ...........................4-12

4-10 Surface water sampling locations, Livermore Valley ...........................................4-13

4-11 Rainwater sampling locations, Livermore site and Valley ...................................4-14

4-12 Groundwater sampling locations, Livermore Valley .........................................4-15

4-13 Highest annual average tritium concentration in rainfall (1987-92) ....................4-16

4-14 Storm-water sampling locations ..............................................................

4-15 Soil sampling locations ..................................................................................

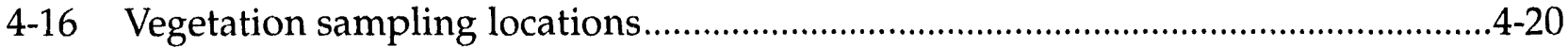

4-17 Highest annual average tritium concentration in vegetation (1987-92) ................4-22

4-18 Highest annual average tritium concentration in honey (1987-92) ......................4-22

4-19 Highest annual average tritium concentration in goat milk (1987-92) .................4-22

4-20 SNL/California perimeter dosimeter locations ................................................4-24

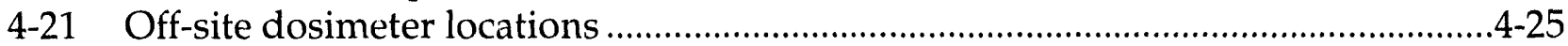

5-1 Major radiation exposure pathways .....................................................................

5-2 Sources of radiation received by a U.S. resident ..................................................5-6

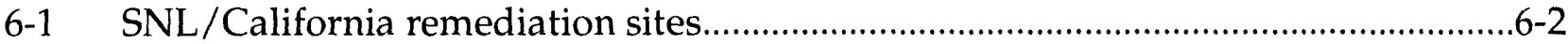

7-1 Groundwater monitoring well locations on the SNL/California site .....................7-2

C-1 Major radiation exposure pathways ....................................................................

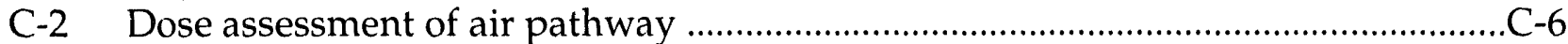

C-3 Dose assessment of terrestrial food chain pathway ............................................ 10 


\section{Tables}

3-1 Major Federal Environmental Regulations Applicable to SNL/California..............3-14

3-2 Projects Submitted to DOE in 1992 for NEPA Review.............................................3-15

3-3 SNL/California Bay Area Air Quality Management District Permitted Sources..3-15

3-4 BAAQMD Exemptions Granted SNL/California in 1992 .........................................3-17

3-5 Environmental Audits of SNL/California in 1992 ...................................................-18

3-6 Corrective Actions Taken by SNL/California in 1992 .................................................3-18

3-7 Environment-related Occurrence Reports ......................................................................3-19

3-8 SNL/California Environmental Permits in 1992 .......................................................

4-1 Environmental Sampling Program Overview ...........................................................4-26

4-2 LECS Wastewater Analyses ....................................................................................4-26

4-3 Semiannual Monitoring Data for the Sandia Categorical Processes.........................4-27

4-4 Weekly Metals Monitoring Data for the Sandia Sanitary Sewer Outfall .................4-28

4-5 Weekly Physical Monitoring Data for the Sandia Sanitary Sewer Outfall...............4-30

4-6 Monthly Priority Pollutant Monitoring Data for the Sandia Sanitary

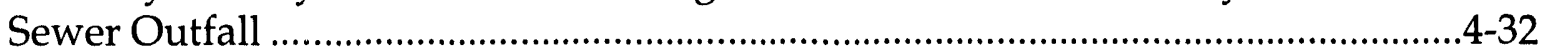

4-7 Wind Direction vs. Wind Speed ......................................................................... 4-32

4-8 Uranium Concentrations in Air, Measured at the Site Perimeter ............................4-33

4-9 Tritium Concentrations in Air, Measured in the Livermore Valley ...........................4-34

4-10 Tritium Concentrations in Air, Measured at the Site Perimeter .................................4-35

4-11 Tritium Concentrations Measured in Livermore Valley Surface

Water Samples...............................................................................................................4-36

4-12 Tritium in Rain, Measured at the Livermore Site and in the Livermore

- Valley.

4-13 Gross Alpha and Beta Activity Measured in Livermore Valley Surface

Water Samples.................................................................................................................4-38

4-14 Tritium Concentrations Measured in Livermore Valley Groundwater

Samples .....................................................................................................................

4-15 Various Radionuclides Measured in Storm-water Runoff at the

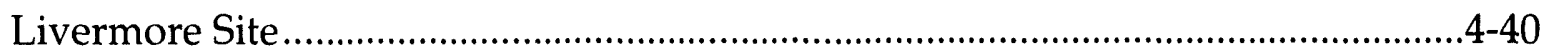

4-16 Storm-water Runoff, Nonradioactive Parameters .....................................................4-40

4-17 Radionuclides Measured in Soil and Arroyo Sediments...........................................4-41

4-18 Positively Detected Metals in Arroyo Sediments Near the

Livermore Site (mg/L)..........................................................................................4-41

4-19 Positively Detected Organic Compounds in Arroyo Sediments

Near the Livermore Site $(\mathrm{mg} / \mathrm{kg})$..........................................................................4-42

4-20 Tritium Concentrations Measured in Livermore Valley Vegetation .........................4-42

4-21 Tritium Concentrations Measured in Retail Wines ......................................................4-43 
Tables

Page

4-22 Tritium Concentrations Measured in Livermore Valley Honey …...........................4-43

4-23 Tritium Concentrations Measured in Livermore Valley Goat Milk .........................4-44

4-24 Quarterly and Annual Environmental Radiation Measurements at

Livermore Site Perimeter Locations

4-25 Quarterly Environmental Radiation Measurements at Livermore

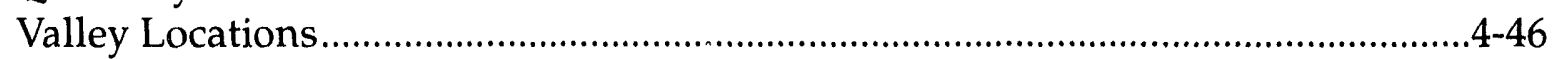

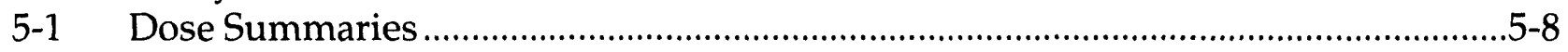

5-2 Effect Dose Equivalent and Individual Lifetime Risk for Critical Receptors ............5-8

5-3 Examples of Consumer Products Containing Radionuclides......................................5-9

5-4 Comparison of Various Radiation Doses ......................................................................5-9

6-1 Average Daily Waste Generation Rate at SNL/California .........................................6-17

6-2 SNL/California Waste Transporters and Disposal Companies Used in 1992 ........6-17

6-3 SNL/California Site Waste Reduction Summary ……………...................................6-18

6-4 SNL/California Site Recycling Activities (Nonhazardous) .......................................6-18

7-1 Water Quality Parameters and Detection Limits for SNL/California Monitoring Wells ................................................................................................... 7-5

7-2 Highest Positively Detected Parameters in SNL Area Monitoring Wells ...................7-6

8-1 Quality Assurance-Duplicate Sampling, Selected Parameters .................................8-3

8-2 Quality Assurance Analyses for the Environmental Protection Agency's Environmental Radioactivity Laboratory Intercomparison Studies Program ..........8-4

8-3 Quality Assurance for the Department of Energy Environmental Measurements Laboratory (EML) Quality Assessment Program ................................8-4

G-1 Prefixes Used with SI (Metric) Units .GLS-11

G-2 Abbreviations for Commonly Used Units of Measure..............................................

G-3 Conversion Factors for Selected SI (Metric) Units ..................................................

G-4 Sampling Location Designators.............................................................................

B-1 The 46 EPA-designated Metal-finishing Unit Operations …………………............... B-5

B-2 Pretreatment Standards for Metal Finishing Category ……........................................ B-5

B-3 Regulated Toxic Organics .................................................................................... B-6

B-4 Specific Pollutant Limitations for Wastewater Discharged to the Livermore Water Reclamation Plant

C-1 General Description of Radiological Dose Assessment Modeling

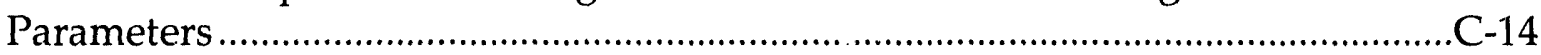

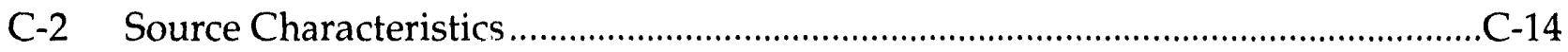

C-3 Radionuclide Characteristics ................................................................................ 


\section{Tables}

Page

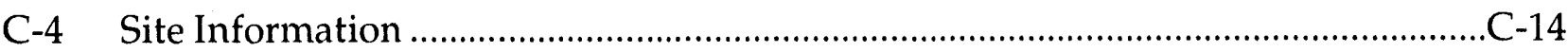

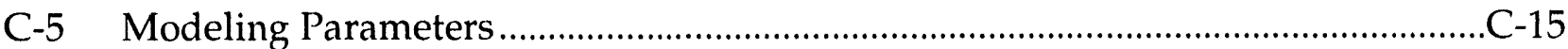

C-6 Values For Radionuclide-Independent Parameters..................................................... -16

C-7A Harmonic Average Wind Speeds (Wind Towards) ................................................... -17

C-7B Arithmetic Average Wind Speeds (Wind Towards) .................................................. 18

C-7C Frequencies of Stability Classes (Wind Towards) .........................................................

D-1 DOE Derived Concentration Guide for Protection of the Public ...............................D-2

D-2 Public Radiation Protection Standards for DOE Facilities ........................................D-2

D-3 California Maximum Contaminant Levels (MCLs) for Public

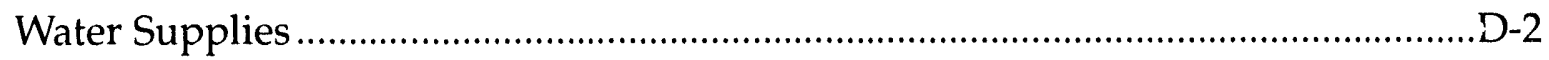




\section{1 - Executive Summary}

Air Monitoring

Water Monitoring

Sewer Monitoring

Soil Monitoring

Vegetation and Foodstuff Monitoring

External Radiation Monitoring

Radiation Impact to the Public

Nonroutine Releases

Compliance with Regulations

Environmental Monitoring Plan 


\section{Executive Summary}

Sandia National Laboratories (SNL) is committed to conducting its operations in an environmentally safe and sound manner. It is mandatory that activities at

SNL/California comply with all applicable environmental statutes, regulations, and standards. Moreover, SNL/California continuously strives to reduce risks to employees, the public, and the envircnment to the lowest levels reasonably possible.

To help verify effective protection of public safety and preservation of the environment, SNL/California maintains an extensive, ongoing environmental monitoring program. This program, conducted in conjunction with Lawrence Livermore National Laboratory (LLNL), monitors all significant airborne and liquid effluents and the general environment in the area. This monitoring effort ensures that emission controls are effective in preventing contamination of the environment. As part of the Environmental Monitoring Program, an ambient environmental surveillance system measures the possible presence of radioactive and hazardous materials in ambient air, surface water, ground water, sewage, soil, vegetation, and locally-produced foodstuffs. The program also includes an extensive environmental dosimetry program, which measures external radiation levels around the Livermore site and nearby vicinity.

Each year, the results of this program are published in this report, the annual Site Environmental Report. The report for 1992 has been expanded to provide a more comprehensive treatment of the Environmental Protection Program at SNL/California. In addition to environmental monitoring, other environmental compliance-related activities are discussed.
This executive summary focuses on impacts to the environment and estimated radiation doses to the public from site emissions. Chapter 3, "Compliance Summary," reviews the various environmental protection activities and the site's compliance status with applicable environmental regulations.

\section{Air Monitoring}

During 1992, airborne contaminant concentrations measured at the Livermore site perimeter and nearby vicinity were well below all applicable air quality standards. The highest annual average tritium air concentration measured at the Livermore site perimeter (in this report, the Livermcre site perimeter refers to both LLNL and SNL/California) was approximately $2.17 \times 10^{-7} \mathrm{~Bq} / \mathrm{mL}$. This level represents $5.9 \times 10^{-3 \%}$ of the Department of Energy (DOE) derived concentration guide (DCG) - the allowable radionuclide air concentration established by DOE for protection of the public (see Appendix D, Table $D-1)$. The highest annual average tritiumin-air concentration measured off-site in the Livermore Valley, was approximately $0.96 \times 10^{-7} \mathrm{~Bq} / \mathrm{mL}$. These data suggest that a substantial portion of the airborne tritium measured at the Livermore site perimeter cumes from natural background sources. The highest annual average uranium $(238 \mathrm{U})$-in-air concentration was approximately $7.39 \times 10^{-5} \mathrm{\mu g} / \mathrm{m}^{3}$. This represents $0.61 \%$ of the DOE DCG. These concentrations are normal, expected levels from background sources.

Both SNL/California and LLNL discharge small quantities of tritium to the atmosphere as a result of routine operations. Consequently, the tritium measured 


\section{Executive Summary}

in ambient air can be attributed to operations at both sites and to natural background sources.

An analysis of the data over the past six years indicates a downward trend in the concentrations of tritium in air (see Fig. 1-1). This can be attributed, in part, to continual efforts by both laboratories to reduce tritium emissions to the atmosphere. In an effort to further reduce tritium levels, SNL/California is planning to phase out all operations involving tritium within the next five years, following DOE approval. Sandia is developing a comprehensive plan for cleaning up the Tritium Research Laboratory (TRL) and transitioning it to other uses. This process is expected to take three to five years, during which time tritium emissions are likely to continue at approximately current rates. According to long-range plans, tritium emissions from SNL/California will be reduced to zero.

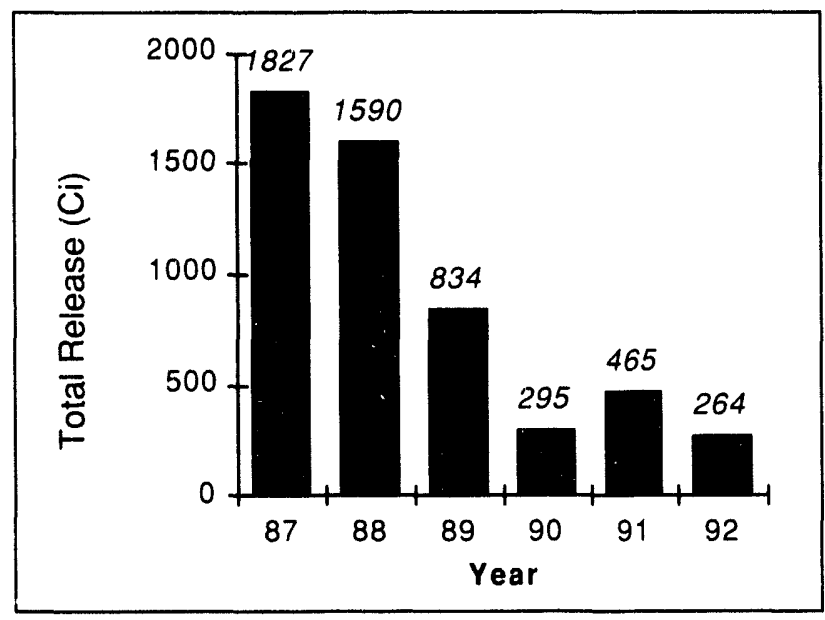

Figure 1-1. Annual airborne tritium discharges from SNL/California, 1987-92.

\section{Water Monitoring}

All major surface-water bodies near the site are monitored routinely for tritium activity. The highest tritium-in-water concentration observed off-site in $1992,2.39 \times 10^{-7} \mathrm{~Bq} / \mathrm{L}$, was $0.3 \%$ of the California Environmental Protection Agency's (Cal-EPA) Department of Toxic Substances Control (DTSC) drinking water standard (DWS) for tritium in public drinking water. ${ }^{1}$ Furthermore, all surface water samples collected in 1992 had tritium levels much lower than the DWS.

Groundwater samples are collected from monitoring wells at the Livermore Water Reclamation Plant (LWRP). Tritium concentrations in wells downgradient of the LWRP were slightly higher than other groundwater samples. Even though these wells monitor an aquifer not used as a drinking water source, the tritium levels were still well below the State DWS. The elevated values near the LWRP are due to the LWRP's past practice of discharging the plant effluent to the Arroyo Las Positas. This practice was discontinued several years ago, and the tritium concentrations have decreased since that time. Now, the tritium levels measured in 1992 in the environment are attributable to emissions from both SNL/California and LLNL, as well as to natural background.

\section{Sewer Monitoring}

The sanitary sewer effluent from the Sandia site is continuously monitored and sampled to ensure compliance with Federal, State and local wastewater discharge limits. Moreover, SNL/California strives to reduce liquid effluent to the lowest levels possible. 
The sewer effluent monitoring data show that regulated metals, physical parameters, radionuclides, and EPA priority organic pollutants were within specific limitations of the discharge permit issued by the City of Livermore. This represents 100\% compliance with permit limits for wastewater discharged at the site sewer outfall.

SNL/California also has a special monitoring program for "categorical processes" subject to EPA wastewater pretreatment standards (Title 40 CFR, Part 433). ${ }^{2}$ During 1992, liquid effluent from these industrial processes achieved $100 \%$ compliance with applicable Federal pretreatment standards.

DOE and the State of California have established allowable limits for discharging radionuclides into a public sewer system (see Appendix B). ${ }^{3}$ These limits have been derived to protect the public and the environment. In 1992, the only radionuclide discharged to the sanitary sewer system in detectable amounts was tritium. A total of $0.061 \mathrm{Ci}$ tritium was discharged as a result of routine operations. This level represents only $6 \%$ of the State allowable limit.

Moreover, the yearly average tritium concentration in the SNL/California sewer effluent was about 50 times below what is allowable in public drinking water.

\section{SOIL MONITORING}

Surface soil and arroyo sediment samples are collected throughout the Livermore Valley. The concentration of ${ }^{238} \mathrm{U}$ in surface soils was within historical background levels and was consistent with levels observed in previous years. Tritium concentrations in arroyo samples collected near the Livermore site were lower than the concentrations noted for surface waters in the
Livermore Valley, indicating that tritium is not building up in the arroyo sediments.

\section{Vegetation and Foodstuff MONITORING}

Samples of vegetation and locally-produced agricultural products were collected in and around the Livermore Valley in 1992. Tritium is the only radionuclide of concern in the terrestrial food pathway from operations at the Livermore site. Tritium is measured in local vegetation, wine, honey, and goat milk. These are the principal agricultural products of the Livermore area.

Wine and honey samples produced in the Livermore Valley showed tritium levels slightly above levels detected in samples from more distant areas. The levels of tritium in goat milk were statistically the same as those observed in previous years.

The levels of tritium observed in foodstuffs produced in the Livermore Valley do not represent a health concern. Although there are no safety standards for tritium in vegetation, wine, honey, and milk, the levels of tritium observed in each of these media were below the concentration limits permissible for tritium in public drinking water.

\section{External Radiation Monitoring} SNL/California and LLNL conduct an extensive program to measure external radiation doses at the Livermore site boundary and throughout the Livermore Valley. The average annual dose equivalent from external radiation measured at the Livermore site perimeter in 1992 was $0.62 \mathrm{mSv}$ (62 mrem). This level was statisti- 
cally less than the background radiation dose measured off-site: $0.66 \mathrm{mSv}$

(66 mrem). These measurements demonstrate that no measurable external dose was due to direct radiation from Livermore site operations during 1992. That is, if a person had resided at the site fence line 24 hours a day, every day in 1992, he or she would not have received any measurable dose of external radiation above the natural background level.

\section{Radiation Impact to the Public}

Small amounts of tritium, a radioactive form of hydrogen, released from SNL/California operations can be transported through the environment to off-site locations, resulting in radiation exposures to the public.

Each year, the radiation impact from site operations is evaluated and made available to the public in this report. Potential radiation doses are calculated for a hypothetical individual who resides off-site and receives the maximum exposure from all exposure routes. This comprehensive dose assessment includes all radiological emission sources and all significant environmental exposure pathways. The methods and models used to do this assessment are approved by DOE and the EPA.

The only measurable radionuclide discharge to the atmosphere from SNL/California in 1992 was tritium. Routine operations discharged $264 \mathrm{Ci}$ tritium to the atmosphere. Figure 1-1 shows the total annual tritium discharges from SNL/California during 1987-92. The chart shows a general downward trend in tritium emissions over the past six years. In part, this can be attributed to SNL/California's continual efforts to minimize emissions to the environment. This performance clearly demonstrates SNL/California's conformance with DOE's policy to keep emissions as low as reasonably achievable (ALARA). It should be noted that tritium emissions in 1990 were unusually low due to a decrease in operations at the TRL.

The maximum potential radiation dose to a resident in an unrestricted (i.e., publicly accessible) area resulting from SNL/California operation in 1992 was $2 \times 10^{-4} \mathrm{mSv}$ (0.02 mrem) effective dose equivalent. This dose was calculated for the point of maximum off-site exposure and represents the cumulative exposure from all significant exposure pathways (inhalation, air submersion, ingestion, and ground-surface irradiation). This level is $0.02 \%$ of the DOE allowable limit for protection of the public (100 mrem effective dose equivalent from all sources and all pathways). ${ }^{3}$

Furthermore, the methods and parameters used to calculate this dose were very conservative-the dose was calculated for the closest off-site resident, located approximately $1 \mathrm{~km}$ northeast of the TRL. A major portion of the food consumed by the hypothetical individual was assumed to have been grown locally. The individual was assumed to reside at this location continuously throughout the year. In addition, all the tritium released was assumed to be the most hazardous form, tritium oxide (HTO). Consequently, this dose is not a dose actually received by anyone, but an upperbound estimate. To put this dose of $0.02 \mathrm{mrem}$ in perspective, it is approximately 20,000 times less than the background radiation dose received in one year by a typical resident of the United States (see Fig. 1-2). 


\section{Executive Summary}

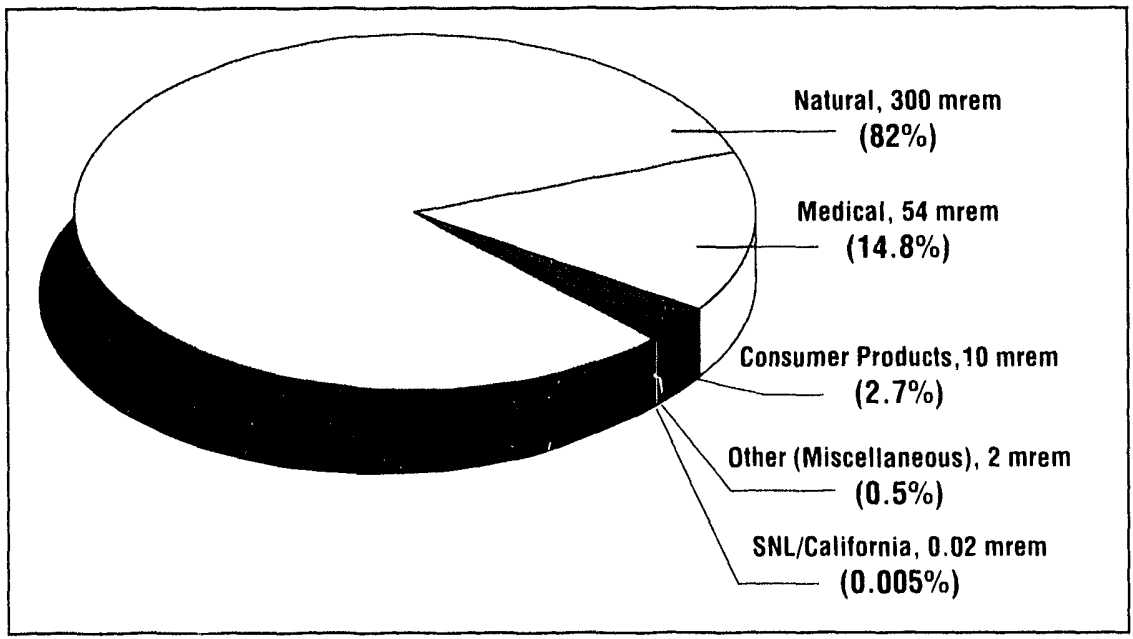

Figure 1-2. Typical radiation dose's received by the general public and the maximum contribution from SNL/Califormin.
Chapter 5, "Environmental Impacts," contains a much more detailed discussion of potential off-site radiation impacts. For more information about the methods and assumptions used to assess these impacts, see Appendix C. Appendix D summarizes the radiation protection regulations for the public.

\section{NONROUTINE RELEASES}

Two nonroutine occurrences caused unplanned releases of radioactive material to the environment from SNL/California operations in 1992 .

- On May 28, 1992, 4 Ci tritium was released to the atmosphere from a leak in a high-temperature vacuum furnace, which is located in a highvelocity fume hood at the TRL. Subsequently, the experimental apparatus was reconfigured and procedures modified to prevent recurrence.

- On June 1, 1992, 36 Ci tritium was released to the atmosphere from the
SNL/California Thermal Outgassing eXperiment (STOX) through the TRL stack. The experimental apparatus was reconfigured so that any system gas is routed through the Vacuum Effluent Recovery System to remove tritium from the gas stream before it is discharged to the atmophere.

\section{Compliance with Regulations}

SNL/California expends considerable effort in order to comply with all applicable Federal, State, and local regulations. The environmental monitoring data demonstrate that all emissions to the environment from SNL/California in 1992 were well within legal standards. For details of significant compliance activities, see Chapter 3 . It summarizes SNL/California's compliance with applicable environmental statutes and regulations for 1992. It also discusses current and ongoing issues related to environmental management. It provides an update of SNL/California's response to the environment, safety, and health findings of the DOE Tiger Team assessment conducted between April 30 and May 18, 1990. 


\section{Executive Summary}

\section{Environmental Monitoring Plan}

$\mathrm{SNL} /$ California has prepared an

Environmental Monitoring Plan 4 in accordance with the requirements of DOE Order 5400.1,5 and DOE Environmental Regulatory Guide EH/0173T. ${ }^{6}$ The Plan serves as a guidance document for the Environmental Monitoring Program at SNL/California. When read in conjunction with the Site Environmental Report (which provides the data from the program for the current year), it provides a comprehensive assessment of the status of Sandia's Environmental Monitoring Program.

The Environmental Monitoring Plan contains a comprehensive review of environmental monitoring at SNL/California, including administrative structure, pathway analysis, effluent monitoring, sampling of environmental media, laboratory procedures, dose calculations, meteorological monitoring, and quality assurance. It details the operations of each of these areas and documents the rationale behind the diverse monitoring methods. In addition to documenting the current state of the monitoring system, the plan provides an indepth review of the adequac; and scientific defensibility of the monitoring program. 
Environment, Safety, and Health

(ES\&H) Organization

Self-Assessment Program

Center for ES\&H and Facilities

Environmental Protection Department

Environmental Monitoring Program

Site Description

Laboratory Setting

Annual Site Environmental Report 


\section{Introduction}

\section{Sandia National Laboratories' ES\&H Vision}

Sandia National Laboratories is committed to protecting the environment and to preserving the health and safety of the individual and the community. We shall provide leadership by setting an example for a safe and healthful workplace and by pioneering industrial practices that protect the environment. We will continuously improve our performance to become a nationally recognized and trusted ESEH resource. Sandia considers the protection of the environment, as well as human life and health, to be its top priority.

SNL/California is a prime contractor to the Department of Energy (DOE), operated by Sandia Corporation under a no-profit, nofee contract. SNL/California's primary mission is conducting research and development in the interest of national security, with principal emphasis on nuclear weapon development and engineering, excluding the nuclear components. More specitically, SNL/California's research includes:

- weapons engineering for all phases of the nuclear-weapons life cycle,

- nuclear materials safeguards and security,

- energy-related re search,

- tritium research (which is being phased out), and

- fundamental research in combustion, geosciences, fusion, and materials sciences.

SNL/California employs approximately 130) people.

SNI./California incorporates the highest regard for enviromment, safety, and health (ES\&H) into every experiment and all site operations. SNL/California operates under the scope of Federal, State, and local regulatory authorities and has obtained all appropriate operating permits. SNI/California is committed to operating in full compliance with the letter and spirit of applicable environmental laws, regulations, and standards. Furthermore, SNL/California strives to go beyond compliance with legal requirements by making every effort practical to reduce impacts to the environment to as low as reasonably achievable.

\section{Environment, Safety, and Health Organization}

The organizational structure to implement SNL'S ES\&H vision at SNL/California is shown in Fig. 2-1. The SNL President has overall responsibility for ES\&H. He is advised by the SNL/California ES\&H Council (SEC) regarding ES\&H issues at the site. Together, they are ultimately responsible for establishing and communicating a corporate culture that recognizes ES\&H as a top priority.

SNI has established a corporate-level ES\&H organization. ES\&H requirements are implemented using written programs and procedures. SNL/California augments the corporate program by maintaining its own site ES\&H organization (Fig. 2-1). This organization implements ES\&H programs and ensures compliance with regulations specific to the California site.

To help assure that ES\&H commitments are fulfilled, SNL/California has estab- 


\section{Introduction}

Figure 2-1. Environment, safety, and health organizational chart as of December 1992.

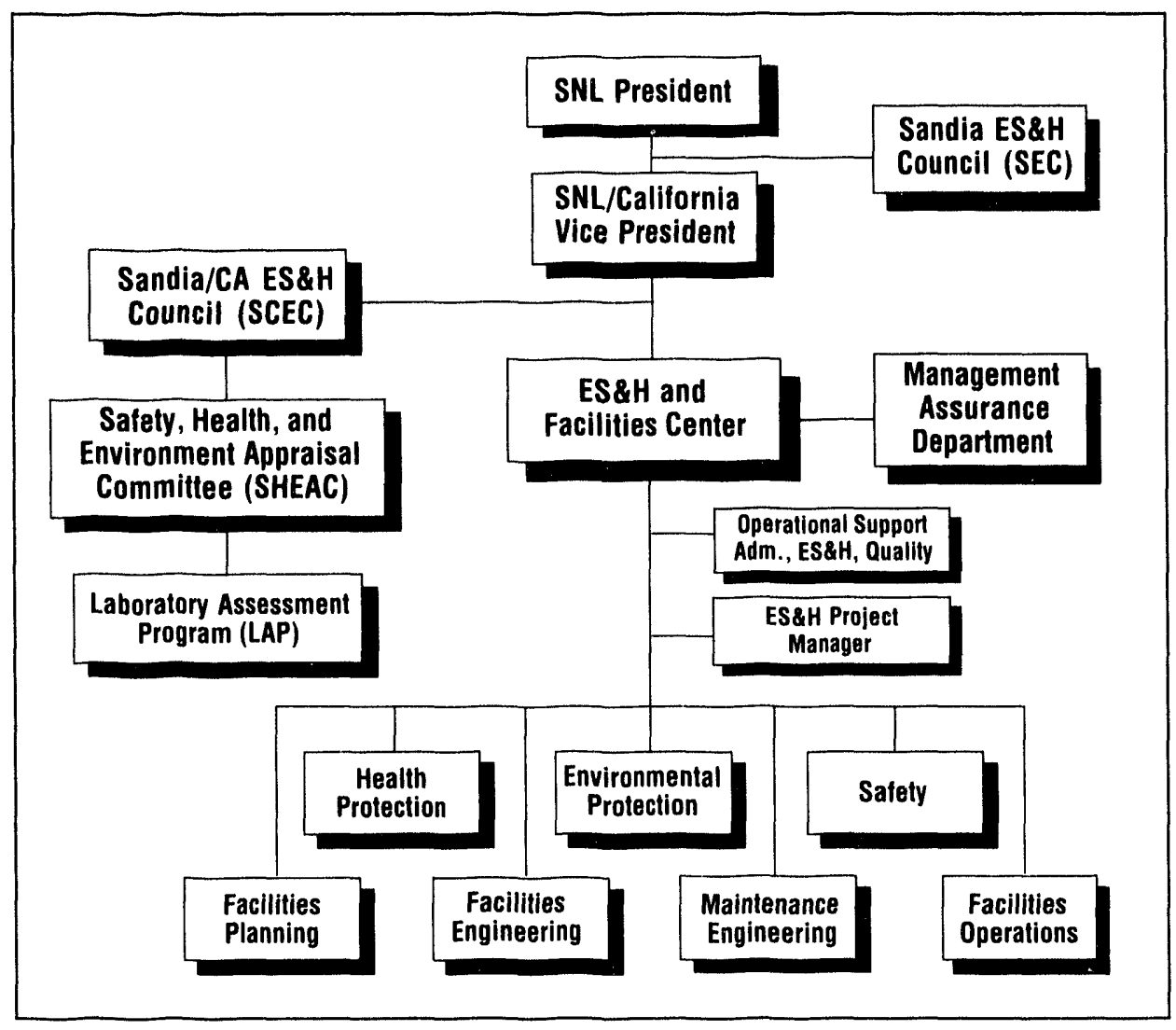

lished an ES\&H Assurance Department and a Vice President ES\&H Council (SCEC). The ES\&H Assurance Department does internal audits and assists line organizations with self-assessment activities to assure that the site is fulfilling its ES\&H responsibilities. The SCEC assists in tracking ES\&H compliance activities and the implementation of ES\&H programs at SNL/California.

\section{Self-Assessment Program}

SNL is developing and implementing a comprehensive system to assess and track ES\&H commitments. The SNL ES\&H Self-
Assessment Program consists of three key sub-programs: Appraisal, Performance Indicators, and Operating Experience Evaluation.

The ES\&H Appraisal Program establishes an internal appraisal hierarchy consisting of independent appraisals, management surveillance, and line inspection activity. The independent appraisals are done under the auspices of the SNL/New Mexico ES\&H Regulatory Assessments organization, which also provides the SNL tracking and lessons learned functions.

The ES\&H Performance Indicator Program establishes a set of quantitative 
Introduction

measures for DOE to evaluate and track the Laboratories' ES\&H performance.

Line organization self assessment is provided principally by the Management Surveillance Program, which is supplemented by inspection activity initiated by line organization management. At the California site, the vice president has established the Laboratory Assessment Frogram (LAP) to fulfill this supplementary inspection requirement.

\section{Center for Environment, Safety, AND HEALTH (ES\&H) AND FACILITIES}

An important part of the mission of the Center for ES\&H and Facilities is to ensure the health and safety of SNL/California employees and the general public, and to protect the environment. This mission is fulfilled by helping SNL/California employees understand and comply with DOE Orders and their legal responsibilities under Federal, State, and local laws and regulations. The Center for ES\&H and Facilities has three departments involved in ensuring workplace safety and protection of the environment: Health Protection, Environmental Protection, and Safety. An ES\&H quality assurance group reports directly to the Center Director and is functionally independent of the departments within the center. The Environmental Protection Department is directly responsible for this report and the activities described herein.

\section{Environmental Protection DEPARTMENT}

The mission of the Environmental Protection Department is to ensure that operations at SNL/California are conduct- ed in an environmentally responsible manner and in compliance with applicable laws and regulations. The department has a variety of environmental programs to properly manage hazardous waste, to enhance environmental quality, and to monitor the impacts of site emissions to the environment. To implement these programs, the department has groups responsible for waste management, waste minimization, environmental technology, environmental monitoring, environmental remediation, air quality, and regulatory affairs (Fig. 2-2).

The following sections briefly describe the activities of these groups.

\section{Waste Management}

The Hazardous Waste Group is responsible for managing radioactive, mixed, and hazardous wastes. Waste management activities include the pickup, transport, packaging, storage, and treatment of wastes in accordance with DOE-, EPA- and Statespecified regulations.

\section{Waste Minimization}

The Waste Minimization Group is responsible for reducing waste generated by site operations as much as possible. This group coordinates source reduction, recycling, and waste treatment (sanitary waste). SNL/California has appointed a waste minimization coordinator to manage the effort.

\section{Environmental Technology}

The Environmental Technology Group is responsible for a wide range of environmental support activities. These include environmental chemical analysis, laboratory quality assurance, and development of a 


\section{Introduction}

Figure 2-2.

Organizational structure of the Environmental Department. Protection

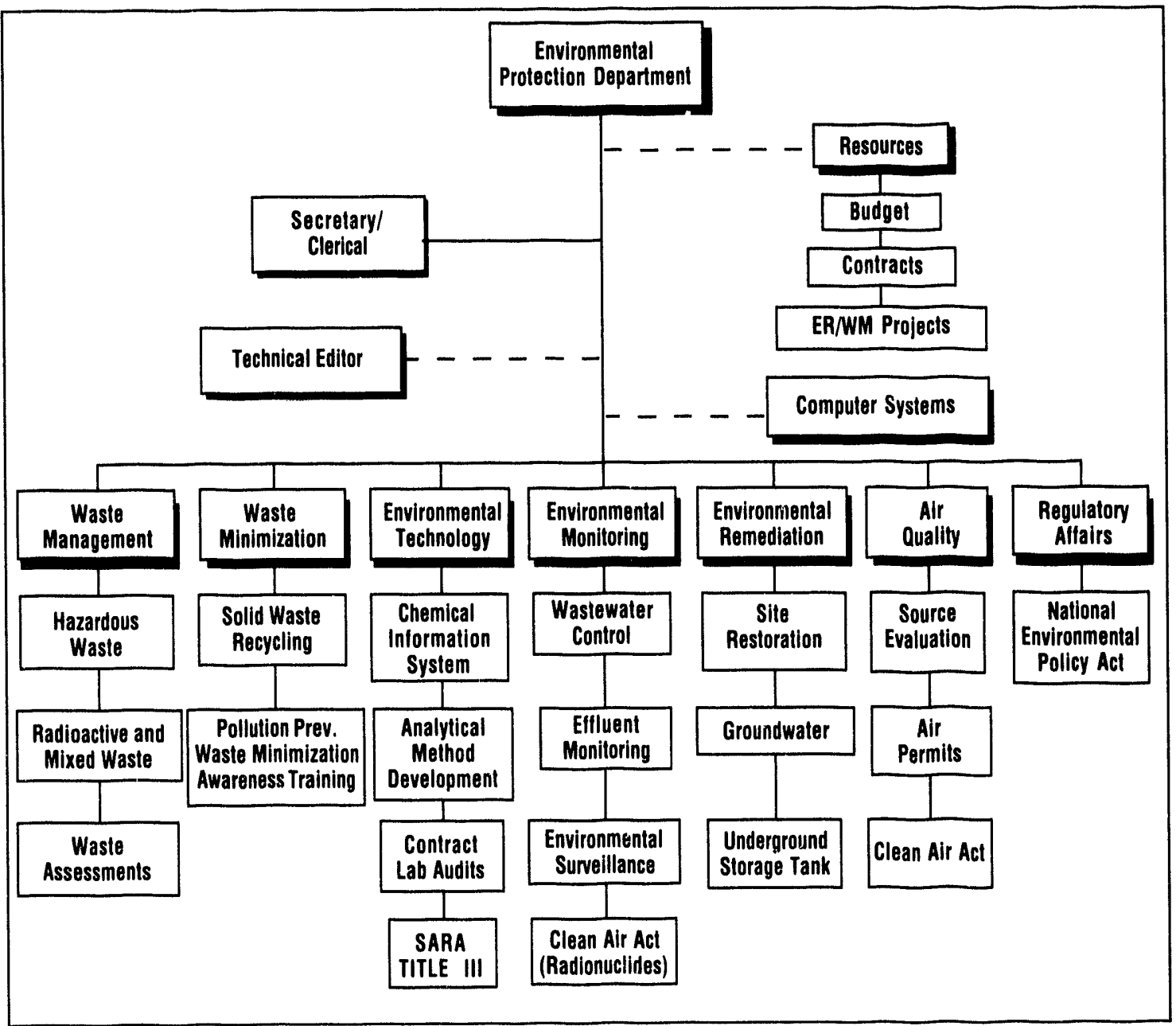

site-wide chemical information management system.

\section{Environmental Monitoring}

The Environmental Monitoring Group is responsible for ensuring that

SNL/California complies with all Federal, State, and local regulations and DOE Orders regarding emissions to the environment. The group monitors airborne emissions sources and wastewater discharges and is responsible for monitoring the general environment of SNL/California and nearby vicinity. The group verifies compli- ance with established standards and ensures there is no environmental degradation due to site operations. The group prepares numerous reports, permit applications, and other documents to demonstrate compliance with various environmental regulations and DOE orders.

\section{Environmental Assessment and Remediation}

The Environmental Remediation Group is responsible for assessing the extent of historical contamination of SNL/California sites and managing any necessary remedia- 
Introduction

tion efforts. This group is also responsible for characterizing groundwater flow and groundwater monitoring.

\section{Air Quality}

The Air Quality Group is responsible for ensuring that SNL/California complies with regulations regarding air emissions to the environment. The air quality compliance program requires the identification and evaluation of potential sources of air pollutants, determination and documentation of compliance requirements, and adherence to operational requirements.

\section{Regulatory Affairs}

The Regulatory Affairs Group evaluates proposed new projects or activities for compliance with the National Environmental Policy Act (NEPA). NEPA requires that SNL/California review each proposed project or modification on-site for environmental concerns. If SNL starts a new project or modifies an existing project (e.g., test or experiment, building or equipment refurbishment, or new project or building), an assessment of the potential environmental impacts must be made. Key environmental issues that must be addressed are air emissions, worker exposures, waste generation and disposal, and waste minimization.

\section{Environmental Monitoring Program}

The Environmental Monitoring Program at SNL/California assesses potential impacts to the public and the environment from site operations. This program consists of effluent monitoring and environmental surveillance.

\section{Effluent Monitoring}

Effluent monitoring is the collection and analysis of samples or direct measurements of liquid and gaseous effluents for the purpose of characterizing and quantifying contaminants released.

Airborne and liquid effluents are monitored to ensure compliance with established limits for release of pollutants into the atmosphere or bodies of water. At SNL/California, tritium is the pollutant of primary concern. Small amounts of tritium are released to the atmosphere as a result of TRL operations. Accordingly, the TRL stack is monitored continuously and the data are used to calculate potential doses to people off-site.

The only water pathways occur as discharges to the sanitary sewer system and surface runoff to the storm sewer system. These pathways are monitored for pollutants that could enter the environment. These data are used to demonstrate compliance with permit limits. These pollutant discharge limits are established to protect receiving waters, such as the San Francisco Bay, and operations at the LWRP.

SNL/California discharges no liquid effluents directly to the ground, arroyo, or any other surface water body.

\section{Environmental Surveillance}

Environmental surveillance involves the collection and analysis of samples of environmental media (e.g., air, water, soil, foodstuffs).

Environmental surveillance is conducted both to verify that emission controls are effective in preserving the local environs 


\section{Introduction}

and to check for possible buildup of pollutants. The potential radiological air emissions from SNL/California are tritium and depleted uranium. Potential pollutant emissions to the sanitary sewer or storm water runoff collection system include tritium, metals, various organic compounds, solids, and minerals.

Because of the close proximity of the two DOE sites in Livermore, SNL/California and LLNL have established a cooperative arrangement for environmental monitoring. LLNL is operated by the University of California and reports to a different DOE Operations Office than SNL/California. (LLNL reports to DOE San Francisco Operations Office, and SNL reports to DOE Albuquerque Operations Office.) Each site monitors its own effluents and performs on-site surveillance. However, most of the off-site environmental samples are collected and processed by LLNL.

LLNL also has facilities available for analyzing extremely low-level radiological samples. The data from LLNL's environmental surveillance sampling are transmitted to SNL/California. Because the facilities are adjacent to each other, distinguishing between their environmental impacts is frequently impossible. SNL/California supplements the LLNL surveillance system by conducting site-specific surveillance (sewer monitoring, stack monitoring, ground water monitoring, and perimeter external radiation surveillance).

The surveillance samples are collected either from near the site boundary (nearfield sampling) or at more distant locations. Logically, near-field samples are more likely to indicate effects from site operations. In general, distant samples are collected to monitor the extent and effect of SNL/California and LLNL's combined operations and particularly the impact on the nearest populations centers. Samples are also collected from areas beyond the influence of the Laboratories' operations in order to assess background (or naturally occurring) concentrations of pollutants.

Air, sewage, and storm water samples are collected to assess the direct impact of operations because effluents may be released directly to these media. To monitor potential public exposure, samples of vegetation, wine, milk, honey, soil, surface water, ground water, and rainwater are collected. External radiation dose rates are also monitored to assess the effects of radioactive materials released to the environment, large isotopic sources of radiation, or radiation-producing machines on-site.

The only environmental media for which regulatory limits have been established are air, drinking water, and sanitary sewer effluent. Limits for soil, vegetation, and foodstuffs have not been established. However, limits have been established for the total dose received from all pathways, to include ingestion. The data from soil, vegetation, and foodstuffs are evaluated in terms of their potential contribution to total doses received by the public.

\section{Site Description}

This section provides an overview of the SNL/California site, physical environment, and ecological characteristics of the area.

\section{Laboratory Facility}

The SNL/California site covers $1.7 \mathrm{~km}^{2}$ (413 acres), which includes 213 acres of 
Introduction

developed areas. In 1986 and 1987, DOE acquired 228 acres to provide a security buffer zone between developed areas and the Laboratory.

The site facilities comprise approximately 801,000 square feet of building floor space. Of this, about $31 \%$ is office and drafting areas, $48 \%$ is light laboratories and shops, and 3\% is heavy laboratories (e.g., high-pressure test facilities and explosives chambers). The remaining $18 \%$ is classified as miscellaneous usage, such as computer rooms and library space.

$\mathrm{SNL} /$ California is a multiprogram laboratory involved in a broad range of research and development. Facilities are designed for small-scale scientific and applied engineering research. There are no production operations at the site.

\section{Integrated Manufacturing Technologies Laboratory (IMTL)}

The new Integrated Manufacturing Technologies Laboratory (IMTL) was dedicated at SNL/California on October 16, 1992. It is a four-building complex located in the southwestern section of the SNL/ California site. It covers nearly 83,000 sq. ft.

$\begin{array}{ll} & \text { Present SNL Facillty } \\ \text { Size: } & 413 \text { acres } \\ \text { Number of buildings: } & 56 \\ \text { Floor space: } & 801,000 \text { sq. ft. } \\ \text { Employee populations: } & \begin{array}{l}1,050 \text { full-time } \\ \text { employees }\end{array} \\ & 250 \text { contractor } \\ & \text { employees }\end{array}$

The IMTL's purpose is to serve as one of the cornerstones of SNL's national Center for Advanced Manufacturing Technologies. This Center has programs at both SNL/New Mexico and SNL/California.

SNL will use the IMTL to develop and integrate industrial efforts in order to improve U.S. economic competitiveness. The IMTL also will be used to continue SNL's support for DOE Defense Programs. The facility will accommodate activities in materials and process research and development, process simulation, engineering design, and manufacturing technology. In addition, space has been dedicated to facilitate prototype fabrication research and to demonstrate agile manufacturing, both for $\mathrm{DOE}$ and private industry.

\section{Emissions and Water Supply}

In general, potential radiological emissions from normal operations at SNL/California comprise small amounts of tritium and depleted uranium. Tritium-related research is being phased out at SNL/California. (The TRL is transitioning to nonradioactive activities.) SNL/California has been involved in very little work involving depleted uranium over the past several years. Nonradiological emissions include nitrogen oxides $\left(\mathrm{NO}_{\mathrm{x}}\right)$, particulates, and precursor organic compounds.

The site's water supply normally comes from the Hetch Hetchy Aqueduct, which is supplemented occasionally by water from the Zone 7 Flood Control and Water Conservation District. Sandia's sanitary sewer effluent merges with the LLNL sewer system, and the combined waste stream discharges to the City of Livermore sanitary 


\section{Introduction}

sewer system at the northwest corner of the LLNL site. The sanitary sewer effluent from the SNL/California site (and from the rest of the Livermore area) is processed at the LWRP. After treatment, the wastewater is transported via pipeline to the San

Francisco Bay. A portion of the treated LWRP effluent is reclaimed and used for local irrigation.

\section{LABORATORY SETtING}

SNL/California is located next to the City of Livermore (population approximately 58,000 ), in eastern Alameda County, $65 \mathrm{~km}$ ( 40 miles) east of San Francisco (Fig. 2-3). The operating area is surrounded on all sides by DOE-owned land, which serves as a buffer zone. The site lies at the western base of the Altamont Hills. To the north is LLNL, and further north is an expanding business park and commercial development. The property to the south and east of the site comprises agricultural and lowdensity residential areas. Although principally residential, the area to the west encompasses a wide range of uses, to include a business park, grazing lands, vineyards, and other small agricultural and industrial developments.

\section{Topography}

The Livermore Valley is an irregularly shaped lowland in the Diablo Range of the

Figure 2-3. SNL/California in a regional setting.

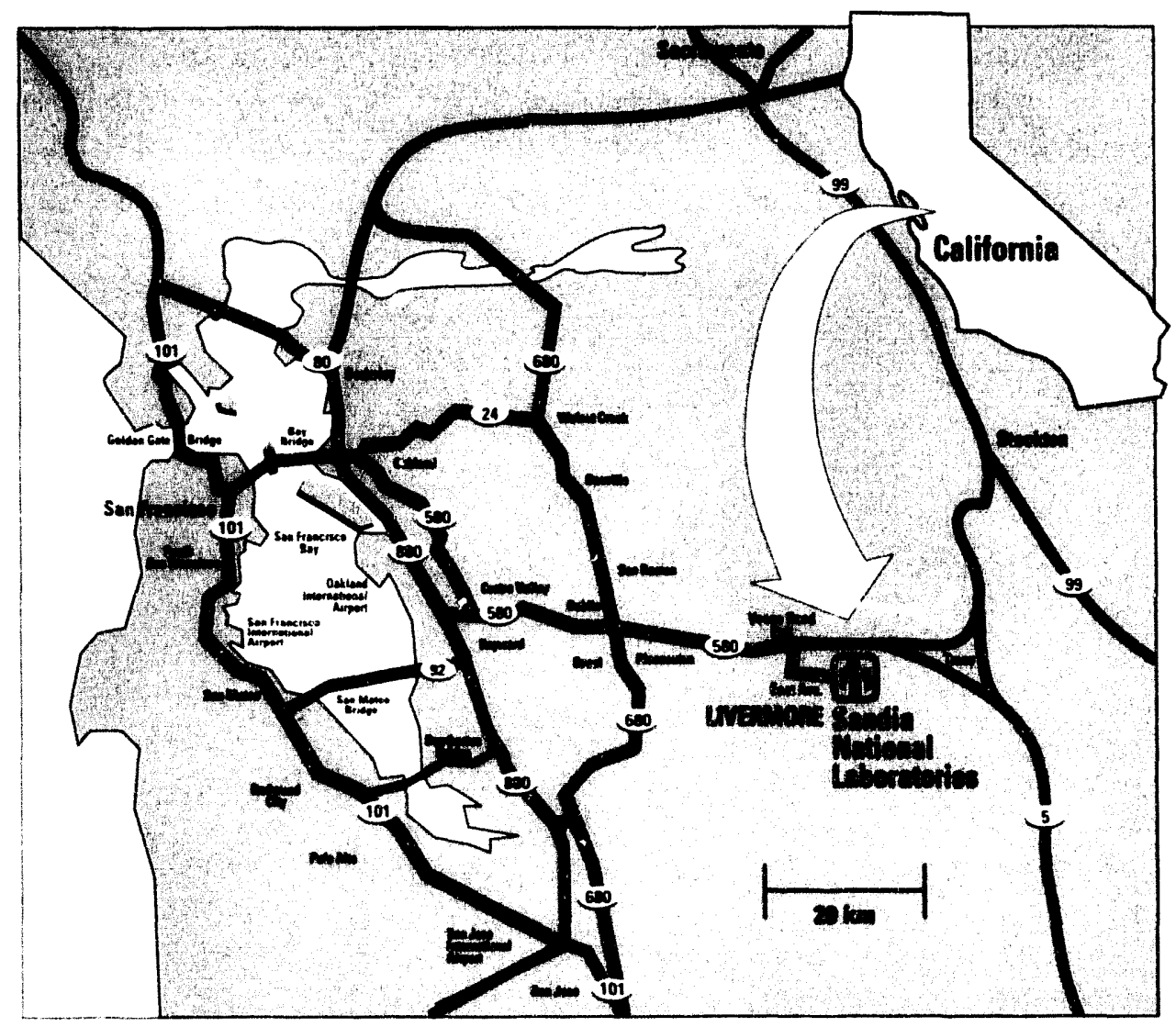


Introduction

California Coastal Mountain Range. The valley is approximately $26 \mathrm{~km}$ ( 16 miles) long (east to west) and averages about $11 \mathrm{~km}$ (7 miles) wide. The valley floor slopes downward, generally to the west at about $10 \mathrm{~m} / \mathrm{km}$ ( $50 \mathrm{ft}$. $/ \mathrm{mile})$. The elevation is approximately $200 \mathrm{~m}(660 \mathrm{ft}$.) at the eastern boundary of the valley and $90 \mathrm{~m}$ $(295 \mathrm{ft}$.) at the southwest corner.

The topography of the California site is generally characterized by relatively flat areas at the northern portion of the site, hills to the south, and steep banks along the Arroyo Seco.

\section{Geology and Hydrology}

The Livermore Valley overlies a complex geologic region where ancient arroyos have deposited a heterogeneous mixture of sand, silt, clay, and gravel. These alluvial deposits create layers of higher and lower permeability overlying the older Livermore formation. The ground water of the Livermore Valley can be found in the more permeable layers, which lie between 5 and $33 \mathrm{~m} \mathrm{(17}$ and $110 \mathrm{ft}$.) below the surface (Fig. 2-4). Groundwater in the Livermore Valley generally flows in a northwesterly direction. The ground water movement underlying the SNL/California site is strongly influenced by the Las Positas Fault Zone. North of the fault, movement is generally westerly. South of the fault, the movement is less distinct, but appears to be radial from a ground water mound. Investigations of groundwater movement in this area are in progress.

Located in west-central California, the site is in a seismically active region. The major faults are San Andreas, Hayward, Calaveras, and Greenville. The closest major faults are Calaveras-about 11 miles west of the site, and Greenville-about 2 miles east of the site. A small, locally active fault, the Las Positas Fault, runs through the site.

Intermittent streams (arroyos) flowing southwest carry surface drainage into the Alameda Creek near Sunol, which continues west to the San Francisco Bay. The Arroyo Seco crosses the site from the southeast to the northwest. Storm-water runoff from the hills to the southeast flows into the arroyo during the rainy season. The arroyo is dry the rest of the year. An $\mathrm{SNL} /$ California site storm sewer system also channels storm water into the Arroyo Seco. This system is the main pathway for the site's surface drainage.

\section{Climate and Meteorology}

The climate of the Livermore Valley consists of mild, rainy winters and warm, dry summers. The mean annual temperature is $12.5^{\circ} \mathrm{C}\left(55^{\circ} \mathrm{F}\right)$, with extremes ranging from $0^{\circ}$ to $38^{\circ} \mathrm{C}\left(32^{\circ}\right.$ to $\left.100^{\circ} \mathrm{F}\right)$. Rain falls primarily between October and April. Precipitation at the SNL/California site in 1992 was $31 \mathrm{~cm}$ (12 in.). The prevailing winds blow from the west and southwest from April to September (Fig. 2-5). The winds are variable during the rest of the year. Specific meteorological measurements for 1992 are summarized in Chapter 4, "Environmental Monitoring Program Information."

\section{Vegetation}

Vegetation on the developed areas of the site consists of plants suitable for general landscaping. The undeveloped land, which mainly comprises the DOE security buffer zone, is dominated by non-native grasses,

SNL/CA Site Environmental Report for 1992 


\section{Introduction}

Figure 2-4. Groundwater contours at SNL/California.

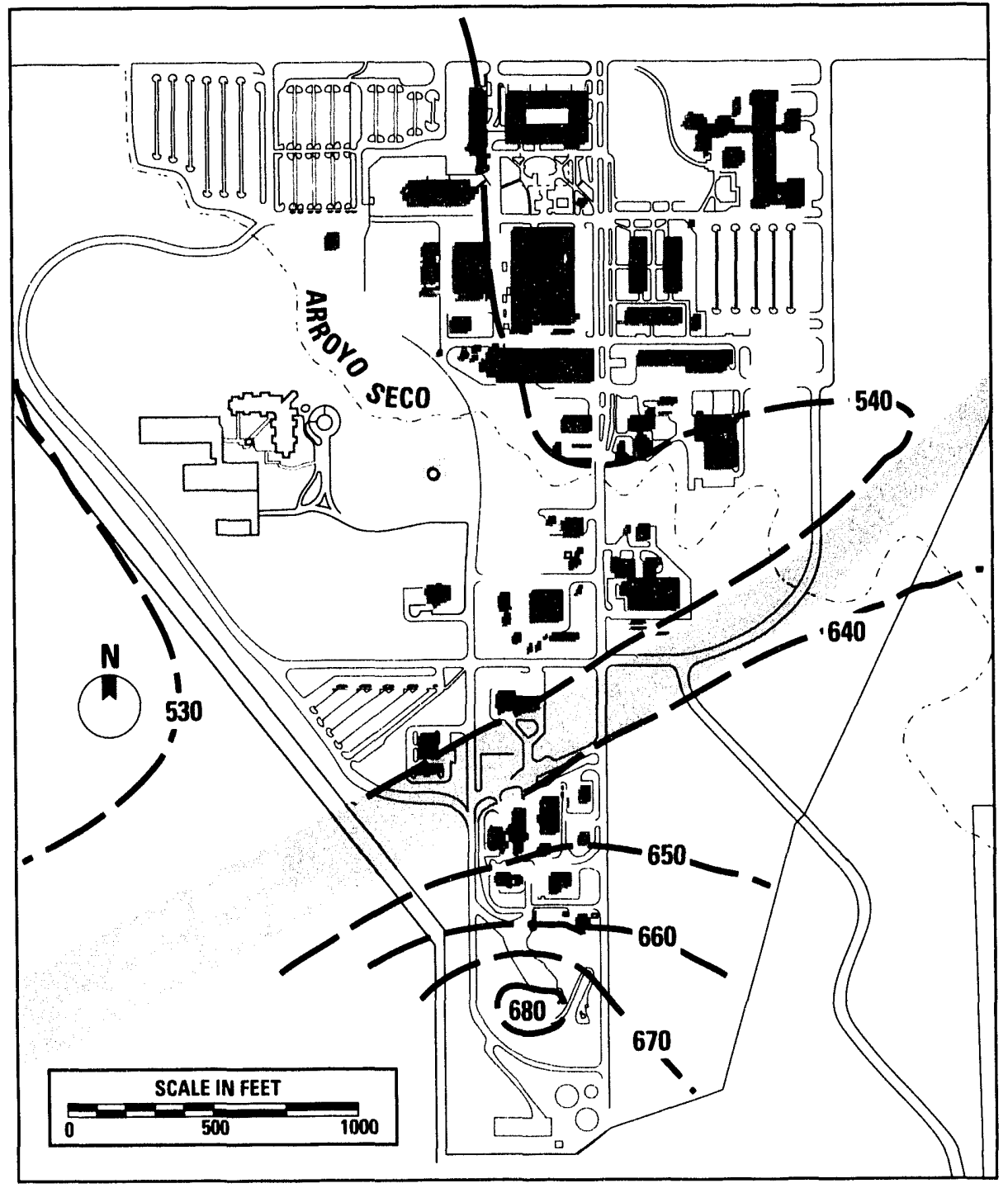

such as slender oat and ripgut brome. Much of this zune is under cultivation to provide erosion control and fire protection.

The Arroyo Seco supports diverse vegetation. There are several large sycamore, valley oak, and red willow trees, as well as patches of cattail and rush at the eastern segment of the arroyo. The central portion of the arroyo hosts a few canyon live oak and almond trees, and annual grasses.

\section{Wildlife}

Wildlife is sparse on the SNL/California site. In 1991, a biological survey identified three species of amphibians and reptiles, 31 species of birds, and ten species of mammals. There are no perennial streams or permanent bodies of water at SNL/California to support fish. Wildlife live in the undeveloped grassland and along the arroyo. Representative species 


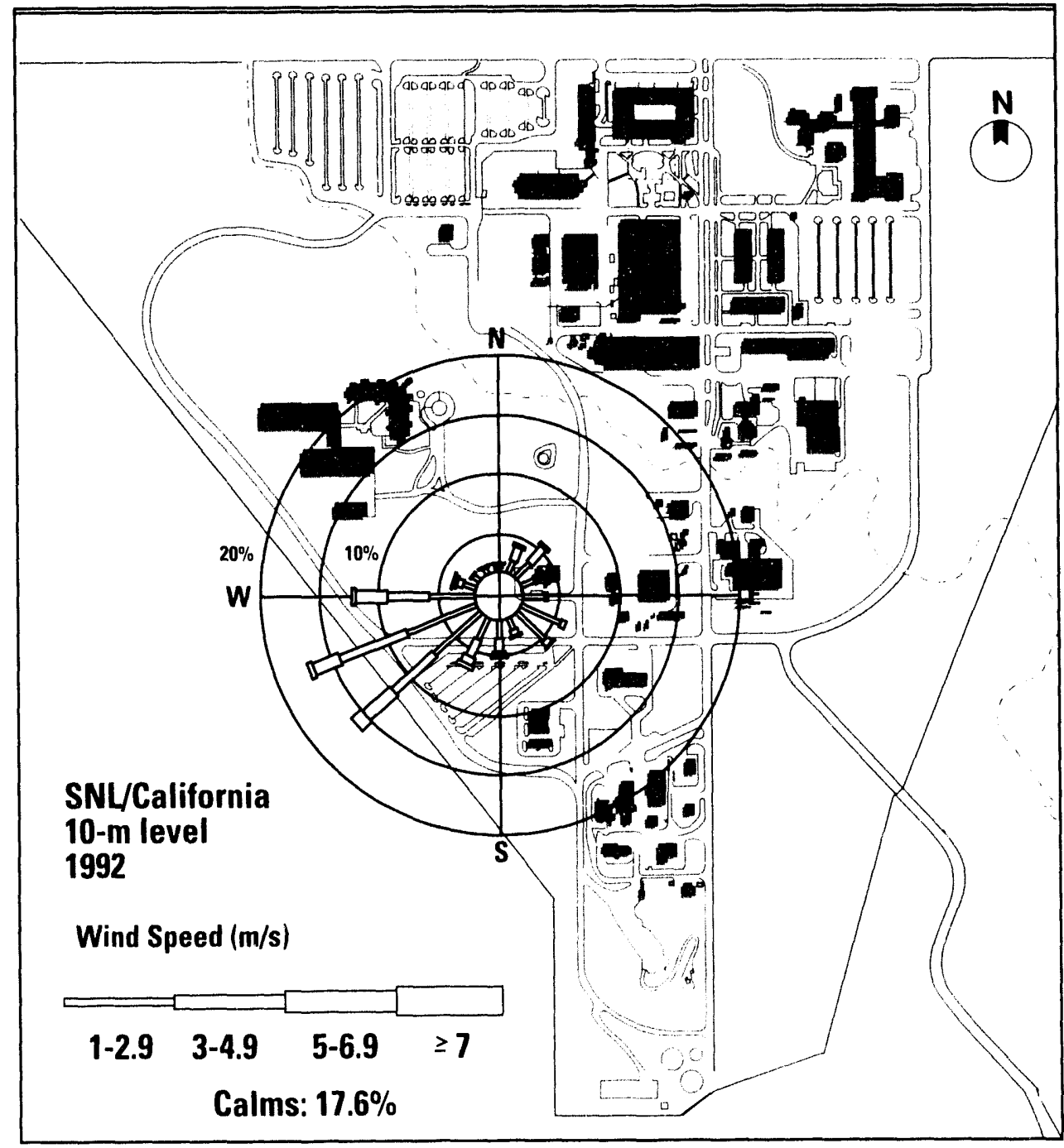

Figure 2-5. Wind rose showing the average anmual avind direction and speed during 1992.

include the fence lizard, black-tailed hare, California ground squirrel, red fox, and western meadowlark.

\section{Annual Site Environmental Report}

This site environmental report documents all SNL/California's significant environmental activities throughout the year. These include effluent and environmental moni- toring, environmental restoration, and protection activities. This report also evaluates SNL/California's compliance with applicable environmental requirements. It is prepared pursuant to the requirements of $\mathrm{DOE}$ Orders 5484.1 and 5400.1.7.5

An extensive glossary defining commonly used acronyms and abbreviations is provided at the end of this report to assist the general reader. An attempt has been 


\section{Introduction}

made in this report to incorporate the International System of Units (SI) or metric system of measurements where feasible. A section on "Units of Measure" has been added to the glossary to assist the reader in understanding the new system of units and quantities.

Appendix A contains laboratory procedures. Appendix B summarizes applicable regulations governing wastewater discharges to the publicly-owned treatment works (POTW). Radiological doses are calculated at the point of maximum credible public exposure, according to EPAapproved methods and incorporating conservative model input and exposure parameters. Appendix $C$ presents the methods, assumptions, and calculations used to assess the routine radiological impacts from SNL/California operations. These measurements are compared to DOE and Federal standards in Appendix D. 


\section{3 -Compliance Summary}

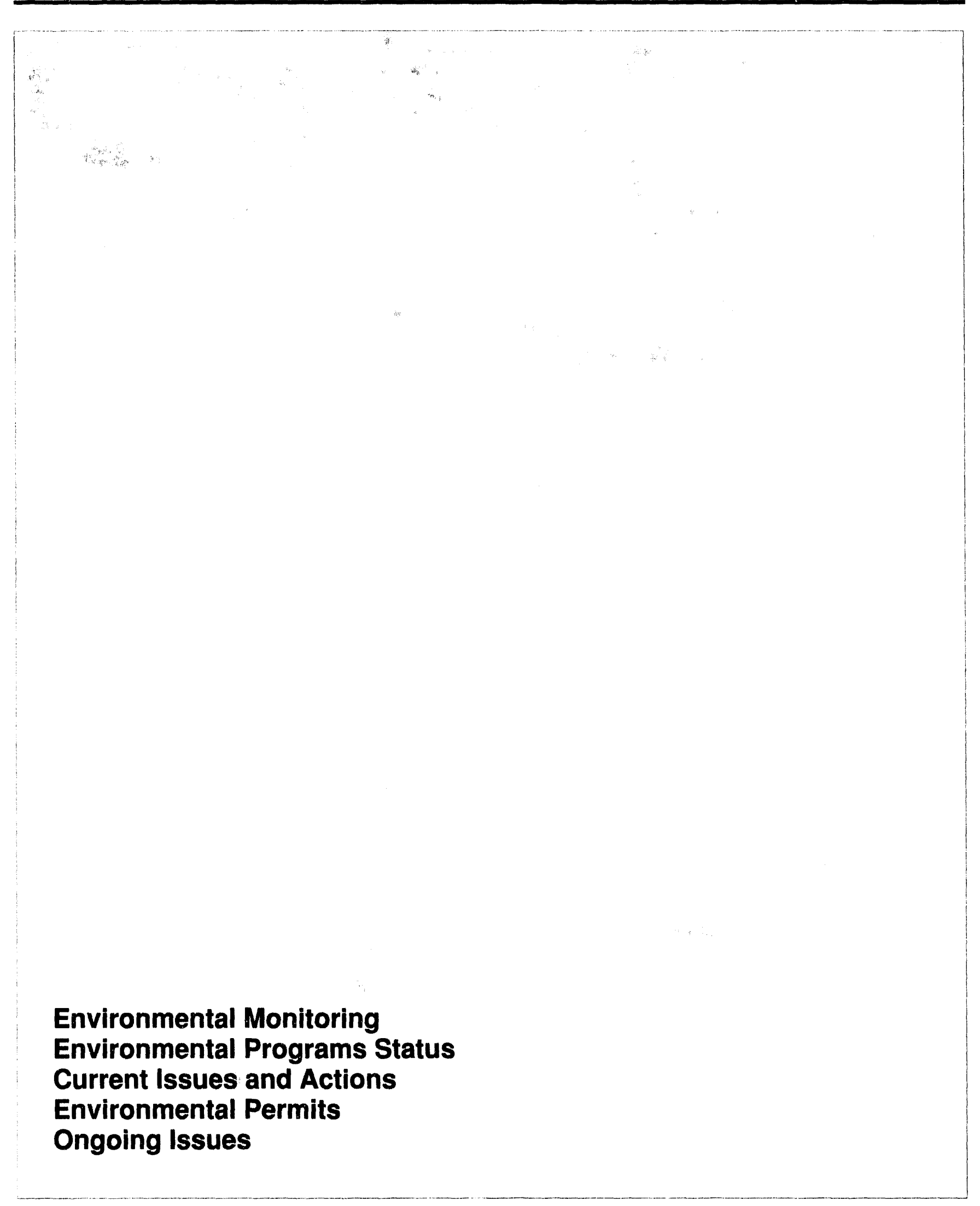




\section{Compliance Summary}

In accordance with DOE policy, SNL must comply with all applicable Federal, State, and local environmental laws and requirements. In addition to meeting specific limits, Sandia is required to keep emissions to the environment as low as reasonably achievable (ALARA). Several Federal, State, and local government agencies are responsible for enforcing and overseeing environmental regulations at SNL/California. The principal agencies include the U.S. Environmental Protection Agency (EPA), the California Department of Health Services (DHS), the California EPA (Cal/EPA), the Department of Toxic Substances Control (DTSC), the Regional Water Quality Control Board (RWQCB), the Bay Area Air Quality Management District (BAAQMD), and the City of Livermore Water Reclamation Plant (LWRP). Table 3-1 summarizes the major Federal environmental statutes that apply to SNL/California operations. State and local authorities also impose a variety of environmental regulations.

This section summarizes SNL/California's environmental management performance and documents the site's compliance with applicable environmental statutes and regulations in 1992. It also discusses current and ongoing environmental management programs. The compliance activities at SNL/California were administered by the Environmental Protection Department. The monitoring data demonstrate that emissions from Sandia during 1992 had no harmful effects on the environment or the public.

\section{EnVIRONMENTAL MONITORING}

SNL/California's emissions to the environment during calendar year 1992 complied with all applicable Federal, State, and local environmental laws and standards. The only detectable radionuclide discharged to the atmosphere from operations at $\mathrm{SNL} /$ California was tritium from the TRL. In 1992, a total of $264 \mathrm{Ci}$ tritium was discharged. Of this amount, $134 \mathrm{Ci}$ was in the form of tritium oxide ( $\mathrm{HTO}$ or $\mathrm{T}_{2} \mathrm{O}$ ) and the remaining $130 \mathrm{Ci}$ was in the form of elemental tritium gas ( $\mathrm{HT}$ or $\mathrm{T}_{2}$ ). Based on these emissions, the potential off-site radiological impact from SNL/California operations was assessed, incorporating all emission sources and all exposure pathways. The assessment was performed using EPAapproved methods and computer codes. In 1992 , the maximum potential dose at a publicly accessible location was $2 \times 10^{-4} \mathrm{mSv}$ (0.02 mrem) effective dose equivalent. This small dose is $0.02 \%$ of the DOE radiation protection standard, and about 20,000 times less than the background radiation dose received in one year by a typical resident of the United States. A more detailed description of the radiological impact assessment is provided in Chapter 5 and Appendix C. Appendix D summarizes the laws governing radiation protection of the public.

The DOE and State of California have established allowable limits for discharging radionuclides to public sewer systems. Tritium is the only radionuclide discharged to the sewer in measurable amounts. During 1992, a total of $0.061 \mathrm{Ci}$ tritium was discharged as a part of routine operations. This is only $6 \%$ of the State allowable limit. 


\section{Compliance Summary}

Appendix B summarizes the regulations for wastewater discharge.

The Environmental Protection Department at SNL/California maintains an environmental surveillance program to verify the effectiveness of emission control measures and to provide a direct measure of any effects on the environment. This surveillance program routinely examines environmental media at the site boundary and in the vicinity. Sampling includes ambient air, surface water, groundwater, sewage, soil, vegetation, and locally-produced foodstuffs. An extensive network of environmental dosimeters is also used to measure external radiation levels. During 1992, the environmental surveillance data demonstrate compliance with EPA and DOE standards.

\section{Environmental Programs Status}

Table 3-1 briefly desc ibes the major environmental regulations applicable to SNL/California.

\section{Comprehensive Environmental Response, Compensation, and Liability Act (CERCLA)}

CERCLA is Federal legislation that establishes a response program for cleaning up contaminated areas in the environment. ${ }^{8}$ SNL/California is cleaning up two sites under the authority of the RWQCB. This activity is funded by the DOE Environmental Restoration and Waste Management Program. Although the assessment and remediation activities are being done under State direction, they follow CERCLA methods.

Pursuant to RWQCB Orders 88-142 and 89-184, 9,10 SNL/California was involved in assessing three sites during 1992: The Fuel
Oil Spill, the Navy Landfill, and Miscellaneous Sites.

- Fuel Oil Spill-As a result of an accidental puncture of an underground transfer line in 1975, approximately 59,500 gallons of \#2 diesel fuel was released into the soil from a reserve fuel tank. Bench-scale tests of various remediation technologies were conducted during 1992. Analysis of the test results indicated in-situ bioremediation to be the most effective and feasible cleanup method. Using a computer code developed at Los Alamos National Laboratory (LANL) and monitoring well data, experts at LANL prepared a threedimensional model characterizing the spill area. Additional bench-scale studies are being done to establish nutrient and oxygen levels and to identify degradation products. Three groundwater wells downgradient of the spill site have been completed.

- Navy Landfill-An inactive landfill, used by the U.S. Navy and LLNL in the 1940s and 1950s, is located on the $\mathrm{SNL} /$ California site. Records indicate that no hazardous materials were disposed of at this site. The site is being investigated to verify this information. According to State requirements for inactive landfills, SNL/California submitted a Solid Waste Water Quality Assessment Test Report to the RWQCB. ${ }^{11}$ Monitoring wells were installed and a sampling program was implemented for both water and soil. Three more wells will be installed under the direction of the RWQCB. 


\section{Compliance Summary}

They will provide additional information about the groundwater.

- Miscellaneous Sites--Under the direction of the California RWQCB, $\mathrm{SNL} /$ California is assessing areas that may have been contaminated due to past operation. In 1992, SNL/California analyzed soil from sites identified during DOE's 1988 Environmental Survey. The results showed no contamination above Resource Conservation and Recovery Act (RCRA) action levels as directed by the State. A report on the sampling and analyses has been sent to the RWQCB. ${ }^{12}$ One of the miscellaneous sites-the "burn pit" - will be included in the Navy Landfill closure. No further action is required at any other site.

\section{Resource Conservation and Recovery Act (RCRA) and the Hazardous Waste Control Law (HWCL)}

Hazardous waste management activities at SNL/California include handling, packaging, and storing energetic, radioactive, mixed, and nonradioactive hazardous waste. SNL/California incinerated small quantities of explosives on-site until October 1989. No other form of hazardous waste disposal has been employed at the $\mathrm{SNL} /$ California site. The only treatment performed on-site is compaction of waste to reduce volume, crushing of fluorescent light tubes to reduce volume, encapsulation of some low-level radioactive waste streams, and consolidation/commingling of various small waste streams at the hazardous waste storage facility.
SNL/California does not generate transuranic or high-level radioactive wastes. Except for liquids generated from scintillation counting (which are sent offsite for incineration), mixed waste is stored on-site. SNL/California has an active waste minimization program and has an approved site-wide Waste Minimization and Pollution Prevention Awareness Program.

During 1992, Hazardous Waste Program compliance-related activities included the following:

- The EPA reviewed the Part B permit application for the incinerator, which was submitted to both the U.S. EPA and Cal/EPA in 1991. SNL/California resubmitted the permit application after addressing all of the EPA's comments. Cal/EPA is still reviewing the revised permit application.

- SNL/California revised the Hazardous Waste Operation Plan and submitted it to the EPA and Cal/EPA.

- The final RCRA Part B permit for the Hazardous Waste Storage Facility was issued to SNL/California. The permit allows SNL/California to store hazardous and mixed waste for one year in Buildings 961 and 962-2 and to conduct limited treatment operations. The effective date is from January 4, 1993, to January 4, 2003.

- The training program for waste management personnel was expanded.

- The DOE Nevada Operations Office audited the SNL/California low- 


\section{Compliance Summary}

level radioactive waste management program. SNL/California has suspended shipment of low-level radioactive waste to the Nevada Test Site until the review is completed in 1993. SNL/California will then resume shipments of low-level radioactive waste to the Nevada Test Site.

\section{National Environmental Policy Act (NEPA) Compliance}

NEPA (1969), as amended, requires SNL/California to consider environmental issues in the review of every proposed project on-site. Because Sandia is a Federal government contractor and uses Federal funds, projects must be examined from an environmental perspective under NEPA.

A major site NEPA document, the Environmental Impact Statement (EIS), was published in August 1992.13 The Secretary of Energy approved the Record of Decision on January 20, 1993. The EIS discusses SNL/California's existing and proposed (for the next five to ten years) mission and projects from an environmental perspective. Each proposed project was determined to have a less-than-significant environmental impact to the site and the surrounding area. Therefore, no additional mitigation is required beyond what Sandia does as part of normal operations.

The EIS provides a base of environmental information according to which Sandia evaluates each proposed project. It discusses SNL/California's continuing operations to provide routine services to the whole site. Such routine operations include maintenance activities, administrative duties, and temporary office space and support activities.
Each proposed new or modified project (beyond those covered in the EIS) must be evaluated according to NEPA guidelines. The DOE Albuquerque Operations Office has designed an Environmental Checklist highlighting key areas of environmental concern to be reviewed for each proposed project. These areas include air emissions, water emissions, waste generation and minimization, soil excavation, transportation of material on- and off-site, threatened and endangered species (flora and fauna), cultural resources (including archaeological and historic resources), restoration projects, and chemicals--use, storage, and disposal. A Checklist completed for a proposed project is submitted to DOE for review and comment. (SNL/California does not approve its own proposed projects.) Only after DOE has approved the Environmental Checklist may SNL/California proceed with the project.

The projects listed and described in Table 3-2 were submitted to DOE in 1992 for NEPA review.

Chapter 6, "Environmental Program Information," provides more information about NEPA activities in 1992.

\section{Clean Air Act/Air Quality Regulations} In 1992, SNL/California complied with applicable laws, regulations, and guidelines governing radiological and nonradiological emissions to the atmosphere, except for two Notices of Violation SNL/California received, which were issued by the BAAQMD in February 1992. These violations applied to operations at SNL/California's paint spray booth. They are discussed in the "Occurrence Reporting" section in this chapter. 


\section{Compliance Summary}

A number of operations at SNL/California are subject to the rules and regulations administered by the BAAQMD because they emit, or have the potential to emit, air contaminants. ${ }^{14}$ The BAAQMD and the California Air Resources Board (ARB) are responsible for setting regulations and providing guidance to attain and maintain EPA and State of California air quality standards.

Tables 3-3 and 3-4 list the permitted sources and exemptions granted to SNL/California. During 1992, SNL/California complied with all the conditions specified in its air discharge permits, except for the two violations discussed above.

\section{NESHAPs Compliance for Radionuclides}

The EPA regulates emissions of radionuclides through the National Emission Standards for Hazardous Air Pollutants (NESHAPS). ${ }^{15}$ On December 15, 1989, the EPA revised its NESHAP's Rule for Radionuclides (Subpart H). It establishes radiation protection standards for protection of the public, monitoring requirements, and annual reporting of radionuclide air emissions. The EPA has established $10 \mathrm{mrem} / \mathrm{yr}$. as the limit on radiation dose received by the public from air emissions. In 1992, the maximum dose from SNL/California's air pathway was $2 \times 10^{-4} \mathrm{mSv}(0.02 \mathrm{mrem})$, or $0.2 \%$ of the Clean Air Act limit.

In 1992, SNL/California completed a site-wide evaluation for compliance with the NESHAPS Rule for Radionuclides. ${ }^{17} \mathrm{~A}$ survey was conducted to identify all uses of radionuclides on-site and to assess the potential for airborne release. The survey identified two facilities (the TRL and the Radioactive Waste Management Facility) that might emit airborne radioactive contaminants. Only one of these, the TRL, had a potential emission that exceeded the EPA criteria $(0.1 \mathrm{mrem} / \mathrm{yr}$. maximum off-site dose) requiring continuous emission monitoring.

The gaseous emissions from the TRL have always been carefully monitored. In 1991, the stack monitoring system was upgraded to ensure full compliance with the emission monitoring and testing procedures of Section 61.93(b) of the NESHAPs rule. ${ }^{15}$ In addition, the cumulative radionuclide emissions from the site are modeled annually using EPA-approved methods. The calculated off-site doses are well below the NESHAP's radiation dose limits. Based on this assessment, SNL/California has determined its operations involving radionuclides comply with the monitoring and radiological dose requirements of NESHAP's.

\section{Clean Water Act/Safe Drinking Water Act}

SNL/California maintains one Wastewater Discharge Permit issued by the City of Livermore. This permit regulates SNL/California's sanitary and industrial effluent that is discharged to the City's sewer system, and enforces the requirements of the Federal Clean Water Act. In 1992, wastewater monitoring analyses showed $100 \%$ compliance with all discharge requirements at the site sewer outfall.

SNL/California operates two metal finishing categorical processes subject to the

SNL/CA Site Environmental Report for 1992 


\section{Compliance Summary}

EPA's pretreatment standards for point sources (Title 40 CFR, parts 403 and 433). ${ }^{16,2}$ Liquid discharges from these processes complied with all applicable regulations for the year.

The drinking water for both SNL/California and LLNL is supplied by the Hetch Hetchy Aqueduct. LLNL monitors the water quality for both sites.

\section{Industrial Storm-Water Discharge}

In 1987, the Clean Water Act was amended [Section 402(p)] to establish a framework for regulating discharges of pollutants in storm water under the National Pollutant Discharge Elimination System (NPDES) program. This stemmed from an EPA study that concluded that storm-water discharges were largely uncontrolled and a leading cause of water quality impairment. Consequently, on November 16, 1990, the EPA published final regulations establishing a permit program for industrial facilities that discharge stormwater to the waters of the United States (Title 40 CFR, Parts 122-124). ${ }^{17}$ The State of California Water Resources Control Board (SWRCB) has been delegated authority by the EPA to issue permits and administer this program.

To comply with the new NPDES permitting requirements of the Clean Water Act, in March 1992, SNL/California filed a Notice of Intent with the SWRCB to be covered under the State's General Storm Water Permit. SNL/California is now covered by the State's General Permit to Discharge Storm Water Associated with Industrial Activities. SNL/California maintains a storm sewer system designed solely to manage storm-water runoff from the site. This drainage system diverts surface water into the Arroyo Seco, which is considered a receiving water of the United States.
SNL/California prohibits discharges other than storm water to the storm sewer. Sandia has developed a Storm Water Pollution Prevention Plan, ${ }^{18}$ as required by the State general permit. ${ }^{19}$

\section{Emergency Planning and Community Right-to-Know Act (EPCRA)-SARA Title III}

The Emergency Planning and Community Right-to-Know Act (also known as the Superfund Amendments and Reauthorization Act (SARA) of 1986, Title III) requires reporting of toxic chemical usage and releases. The purpose of this provision is to make information about potential environmental releases of toxic chemicals available to the public. In accordance with the requirements of EPCRA, Sandia submits reports annually to the EPA and the State of California. In 1992, SNL/California had three substances that were reportable under EPCRA Sections 311 and 312. The three substances and their physical hazards were: No. 2 fuel oil (fire hazard), unleaded gasoline (fire hazard), and liquid nitrogen (asphyxiator, compressed gas, and cryogenic).

\section{Other Environmental Statutes}

In 1992, SNL/California had no activities governed by the following regulations:

- the Federal Insecticide, Fungicide, and Rodenticide Act (FIFRA),

- the Endangered Species Act (ESA),

- the National Historic Preservation Act (NHPA),

- Floodplain Management.(Executive Order 11988), or

- Protection of Wetlands (Executive Order 11990). 


\section{Current Issues and Actions}

\section{Audits and Inspections}

Operations at SNL/California are routinely subjected to internal inspections as part of a rigorous ES\&H Self-Assessment Program.

In addition to this internal scrutiny, SNL/California underwent numerous inspections and audits by external regulatory agencies in 1992. Table 3-5 lists the external inspections by date. It includes the regulatory agency performing the inspection and a general description of each inspection's purpose.

\section{Corrective Actions}

During 1992, SNL/California received five environment-related correc ive action orders from regulatory agencies outside DOE. Table 3-6 describes the violation and gives the response by Sandia and DOE.

\section{Occurrence Reports}

DOE Order 5000.3B, Occurrence Reporting and Processing of Operations Information, 20 requires that occurrences be consistently reported to assure that both DOE and SNL management are kept informed of all events that could: (1) affect the health and safety of the public, (2) seriously impact the intended purpose of DOE facilities; (3) have a noticeable adverse effect on the environment, or (4) endanger the health and safety of workers.

The SNL/California Occurrence Reporting System (ORS) is a process for investigating and notifying DOE about unusual events that occurred at the site. The goals of SNL/California's ORS are to ensure: (1) timely identification, categorization, notification, and reporting to SNL and DOE management; (2) timely evaluation and implementation of corrective actions, including a root cause analysis to identify appropriate corrective actions; and (3) dissemination of lessons learned in analyzing occurrences to prevent recurrence of similar events.

Table 3-7 lists all the environment-related events reported through Sandia's ORS in 1992. Background information, including date, type of occurrence, and brief description of occurrence, is provided for each event reported.

\section{DOE Tiger Team Assessment}

In an initiative to strengthen safety, environmental protection, and waste management throughout the DOE complex, DOE Headquarters established inspection teams of ES\&H experts-commonly referred to as "Tiger Teams." The Tiger Teams provide an independent oversight compliance and management assessment of the ES\&H programs at DOE facilities. The mission of a Tiger Team is to evaluate a DOE site's compliance with environmental and safety requirements, permit agreements, DOE Orders, and best management practices. This initiative is an integral part of DOE's overall plan to ensure full accountability in the area of ES\&H and compliance with regulatory commitments.

A DOE Tiger Team assessment of the ES\&H operations at SNL/California was conducted between April 30 and May 18, 1990. The assessment resulted in 286 key findings, root causes, findings, and concerns. The Environmental Subteam identified a total of 41 findings, three of which were considered key findings. None of them warranted a shutdown at SNL/California. The Environmental Subteam found that environmental and waste management programs at 


\section{Compliance Summary}

SNL/California are generally in compliance with regulatory requirements, but had some fundamental weaknesses. The key environmental findings are:

- There were no formalized environmental policies, quality assurance (QA) programs to implement environmental protection programs, or procedures to ensure that the environmental compliance program at SNL/California was being carried out effectively and in compliance with all requirements.

- The NEPA Compliance Program was inadequate.

- SNL/California was not in conformance with DOE Order 5400.4 (CERCLA) requirements ${ }^{8}$ and the RWQCB Site Cleanup Order No. 89$184^{10}$ for certain remedial response activities associated with inactive waste sites and releases at SNL/California.

In response to the Tiger Team findings, DOE and SNL/California prepared an Action Plan. This Plan has two main purposes. First, it provides a formal written response to each of the findings and concerns cited in the Tiger Team report. Second, it establishes plans, schedules, and costs for activities to be conducted to correct the identified deficiencies. The SNL/California and SNL/New Mexico Tiger Team Action Plans were consolidated in October 1991. Although the consolidated plan is being tracked as a single corporate plan, including planned action for DOE and SNL/New Mexico, 221 of these actions are owned by SNL/California.
SNL/California has made substantial progress towards improving the areas of weakness identified by the Tiger Team. Much effort has focused on strengthening the management oversight and formality of operations relating to ES\&H programs. Some of the major improvements made at SNL/California since the Tiger Team assessment are listed below:

- SNL has restructured and expanded its ES\&H organization to increase ES\&H services.

- A company-wide quality initiative that includes ES\&H is underway.

- A Conduct of Operations/Quality Assurance Program has been created to implement DOE Order 5480.1B, Conduct of Operations, ${ }^{21}$ and DOE Order 5700.6C, Quality Assurance. 22 These DOE Orders have been issued to establish and maintain plans and actions to assure quality achievement in DOE programs.

- A formal Quality Assurance Program has been established in Sandia's Center for ES\&H and Facilities.

- A site-wide self-assessment program has been implemented.

- SNL/California has completed its Environmental Monitoring Plan, which documents all aspects of the monitoring program. ${ }^{4}$

Figure 3-1 summarizes the status of planned actions scheduled for completion during calendar year 1992. As shown in the chart, 221 planned actions (owned by SNL/California) were due for completion 


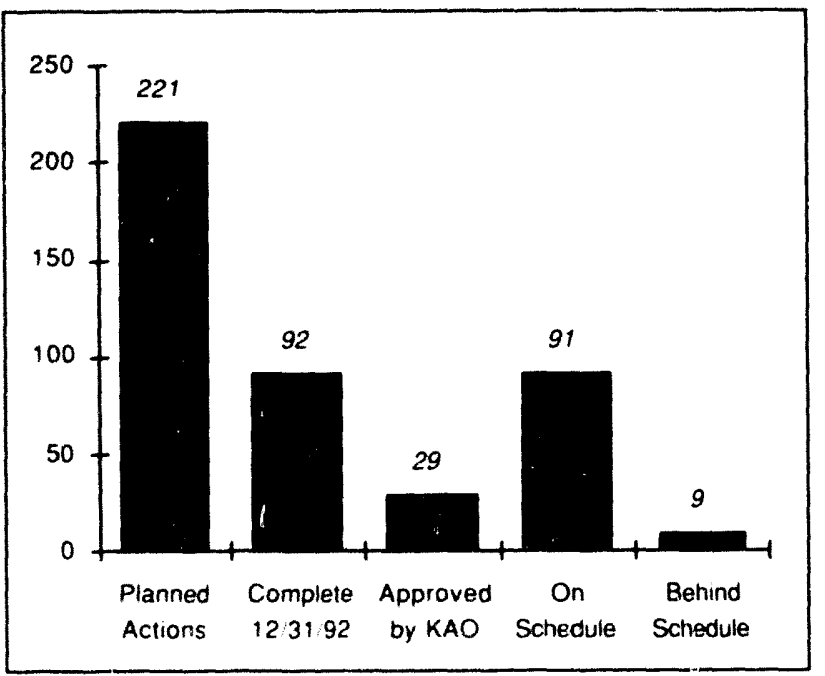

Figure 3-1. Status of SNL/California's Action Plan in response to the DOE Tiger Team findings.

by December 31, 1992. Of these, 92 were completed, 29 were approved by the DOE Albuquerque Operations Office, 91 are on schedule to be completed, and 9 are behind schedule. SNL/California has requested DOE to extend the completion dates for the 9 past due actions.

\section{Self-Assessment Program}

The Sandia ES\&H Self-Assessment Program consists of three key subprograms: Appraisal, Performance Indicators, and Operating Experience Evaluation. The ES\&H Appraisal Program establishes an internal appraisal hierarchy consisting of indepencient appraisals, management surveillance, and line in spection activity. The independent appraisals are done under the ES\&H Regulatory Assessments organization, which also provides the SNL/California tracking and lessonslearned functions. The ES\&H Performance Indicator Program establishes a set of quan- titative measures for DOE to evaluate and track the La joratories' ES\&H performance. Line organization self-assessment is provided principally by the Management Surveillance Program. Line managers may also dictate inspection activity, as necessary. SNL/California has established LAP to assist with this supplementary inspection.

SNL/California has developed and implemented a comprehensive system to track deficiencies found during ES\&H compliance inspections. The system is called DefTrack. It follows deficiencies from the iime they are identified to the time they are corrected, as verified by the auditing agency.

\section{State Oversight Program}

On September 6, 1990, DOE signed an Agreement in Principle (AIP) with the State of California to provide California's citizens independent assurance that DOE sites are fulfilling their commitments to health, safety, and the environrnent. The Environmental Management Branch of the Department of Health Services (DHS) is the lead agency for the State of California. Long-standing DOE policy states that sites will comply with all applicable environmental statutes and regulations. The AIP is a cooperative effort between the State environmental regulatory agencies and DOE facilities in California to help ensure protection of the public and the environment. DOE has agreed to provide the State access to its facilities, comprehensive monitoring data, and funding to support the AIP. The State is currently developing an implementation plan for independent monitoring and oversight of DOE sites, including Sandia. AIP teams visited SNL/California several times 


\section{Compliance Summary}

in 1992 to evaluate environmental programs. The results of the oversight program by the State under the AIP will be documented in future annual site environmental reports.

\section{Environmental Permits}

Table 3-8 identifies the environmental permits held by SNL/California in 1992 and the regulatory agencies responsible for enforcing the respective regulations and permit conditions. At the end of 1992, SNL/California had BAAQMD permits for 35 sources of air pollutants, such as boilers, the incinerator, vapor degreasers, and a paint spray booth.

\section{Hazardous Waste Permits}

Since December 1983, the Hazardous Waste Storage Facility has been operated under a "Part B" permit granted by the State of California under the RCRA program. In June 1988, SNL/California's Hazardous Waste Operation Plan was revised as part of the permit renewal process. ${ }^{23}$ The Part B Permit expired in December 1988. Sandia was granted interim status because it had filed a revised Hazardous Waste Operation Plan in a "timely manner."

Due to changes in the hazardous waste regulations between June 1988 and February 1989, the Hazardous Waste Operation Plan was revised again. Sandia was notified in April 1989 that the Part B application was complete, and a technical review would be completed within 180 days. In October 1990, the State of California notified SNL/California that the technical review of the Part B permit was delayed. Once again, regulatory changes required $\mathrm{SNL} /$ California to update its
Operations Plan to conform to a new format. This plan was resubmitted in December 1990. At the request of the $\mathrm{Cal} / \mathrm{EPA}$, the Part B permit was revised again and resubmitted in June 1992, and then again in August 1992.

As provided by the 1984 Hazardous and Solid Waste Amendments to RCRA, the Cal/EPA conducted a RCRA Facility Assessment in April 1991. The RCRA Facility Assessment report was issued in September 1991. Cal/EPA revised this report and reissued it in March 1992. It identified three Solid Waste Management Units at SNL/California: the Fuel Oil Spill, the Navy Landfill, and Miscellaneous Sites. However, because these units were being assessed and remediated as part of the RWQCB Order, no corrective action was required.

In October 1992, the EPA and Cal/EPA issued a draft Part B permit for the Hazardous Waste Storage Facility. The public and the DOE Albuquerque Operations Office commented on the draft permit. The Cal/EPA issued the final Part B permit on December 4, 1992. The permit is effective from January 4, 1993, to January 4, 2003.

All waste handling operations at SNL/California are conducted according to the most recent State and Federal regulations. More information on SNL/California's Hazardous Waste Program is provided in Chapter 6.

SNL/California did not use its small onsite incinerator in 1992. The incinerator is permitted by the BAAQMD. The incinerator has been used in the past to destroy classified documents and medical wastes. A Part B permit application with subpart $O$ exemption for operation of the incinerator 
was submitted in September 1991 to the EPA and Cal/EPA. The Cal/EPA is still reviewing this permit application.

SNL/California applies for several Extremely Hazardous Waste Disposal Permits annually (see Table 3-8). The Cal/EPA requires this permit for each shipment of extremely hazardous wastes to offsite disposal facilities.

\section{Air Quality Permits}

To comply with the NESHAPs Rule for Radionuclides, ${ }^{15}$ SNL/California must obtain approval from the EPA before starting construction on new sources that may emit radionuclides, or before modifying existing sources. SNL/California has received written approval for operating the low-level tritium evaporator at the TRL.

In 1992, SNL/California had permits from the BAAQMD for 35 sources of air pollutants, such as boilers, the incinerator, vapor degreasers, a paint spray booth, and various abatement devices. (Table 3-3 lists the BAAQMD air discharge permits held by Sandia in 1992. Included is a description of each source and any permit conditions. BAAQMD permits are renewed annually. Table 3-4 lists sources officially exempt from permitting by the BAAQMD.

\section{Wastewater Discharge Permit}

SNL/California holds one Wastewater Discharge Permit issued by the LWRP. This permit regulates SNL/California's sanitary and industrial liquid effluent that is discharged into the City's sewer system. It is renewed annually. It contains discharge limits for the site sanitary sewer outfall and for processes subject to EPA pretreatment standaris. The permit also contains liquid effluent monitoring and reporting requirements. For more details, see Appendix B, which summarizes the conditions of SNL/California's Wastewater Discharge Permit.

\section{ONGOING IsSUES}

This section has been included in the report to provide updated information about SNL/California's environmental protection activities. It discusses the site's environmental compliance record for the the first quarter of 1993 (January 1 to April 1). It also discusses environmental issues and significant accomplishments during this quarter.

\section{Environmental Monitoring}

All monitored airborne and liquid emissions from SNL/California complied with applicable Federal, State, and local laws and standards during the first quarter of 1993. Furthermore, there were no unusual or accidental pollutant emissions to the air or sewer system from the site. The only radionuclide discharged to the atmosphere in measurable amounts was tritium. From January 1 to March 31, 1993, a total of $45.3 \mathrm{Ci}$ tritium was emitted. This is consistent with normal operations at the facility. During this same period of time, $0.0028 \mathrm{Ci}$ tritium was discharged to the sanitary sewer system as a result of routine operation at the TRL. This represents $0.28 \%$ of the State of California allowable release of radioactivity. There were no accidental releases of radionuclides to the environment. In addition, there were no nonradioactive or hazardous chemical pollutants discharged to the sewer system in excess of permit limits. Overall, SNL/California 
demonstrated full compliance with all environmental emission standards during the first quarter of 1993.

To verify the effectiveness of pollution control measures, SNL/California maintains an ongoing environmental surveillance program that routinely examines all significant environmental media. The available environmental surveillance data for 1993 show that all pollutant levels are well within allowable standards established by the EPA and DOE.

\section{Comprehensive Environmental} Response, Compensation, and Liability Act (CERCLA)

The Environmental Restoration Program is involved in assessing and cleaning up contaminated sites at SNL/California. Notable activities and accomplishments during the first quarter of 1993 are discussed below.

Groundwater monitoring at the environmental restoration sites for the first quarter of 1993 was completed. The Quarterly Groundzuater Monitoring Report was submitted to the RWQCB on April 12, 1993. ${ }^{24}$ The significant findings of the report are as follows:

- Fuel Oil Spill Site

- one well contained diesel above the maximum contaminant level (MCL); diesel was detected at $52,500 \mu \mathrm{g} / \mathrm{L}$.

- two wells contained benzene above the MCL $(1 \mu \mathrm{g} / \mathrm{L})$; benzene was detected at $1.2 \mu \mathrm{g} / \mathrm{L}$ and $4.2 \mu \mathrm{g} / \mathrm{L}$.

- Arroyo Seco

- no constituents were detected above the MCL.
- Navy Landfill Site

- two wells contained chromium above the primary DWS $(0.05 \mathrm{mg} / \mathrm{L})$; chromium was detected at $1.8 \mathrm{mg} / \mathrm{L}$ and $8.4 \mathrm{mg} / \mathrm{L}$.

- one well rontained nitrate/nitrite above the primary DWS (45 $\mathrm{mg} / \mathrm{L})$; nitrate/nitrite was detected at $64 \mathrm{mg} / \mathrm{L}$.

- some wells exceeded secondary DWS for iron and manganese (these standards apply to aesthetics and taste of the water, not health issues).

- Trudell Auto Repair Site

- MW-406 was found to contain trichloromethane at $4.7 \mu \mathrm{g} / \mathrm{L}$ $(\mathrm{MCL}$ is $100 \mu \mathrm{g} / \mathrm{L})$, trichloroethylene (TCE) at $0.7 \mu \mathrm{g} / \mathrm{L}$ (MCL is $5 \mu \mathrm{g} / \mathrm{L}$ ), and tetrachloroethene at $2.5 \mu \mathrm{g} / \mathrm{L}$ (MCL is $5 \mu \mathrm{g} / \mathrm{L}$ ).

\section{Resource Conservation and Recovery Act (RC 3A)}

The Hazardous Waste Management Program at Sandia manages all aspects of hazardous waste, from generation to proper disposal. Two notable regulatory events occurred during the first quarter of 1993.

The DTSC inspected SNL/California's hazardous waste operations on February 6 and 16, and March 15, 1993. The Cal/EPA issued a Notice of Violation to Sandia on March 23, 1993. The eight issues identified in the Notice of Violation apply to paperwork deficiencies or minor operational deficiencies that did not pose a threat to 
public or worker health or safety.

SNL/California either corrected the deficiencies or responded to disputed issues in a letter submitted to the Cal/EPA on April 22, 1993. SNL/California has not yet received a response from the Cal/EPA. At this time, SNL/California believes it is in compliance with hazardous waste regulations.

\section{National Environmental Policy Act (NEPA)}

During the first quarter of 1993, no projects required evaluation ander NEPA (no) Environmental Checklists were required).

\section{Air Quality}

From December 1992 to January 1993, fifteen laboratories were reassessed to verify continuing compliance with air quality regulations. The assessments covered permit requirements, toxic air contaminant usage, and potential new sources. The asse'sments discovered no areas of noncompliance.

\section{Clean Water Act}

SNL/California maintains an extensive wastewater control program to ensure that industrial liquid effluents comply with conditions of the site Wastewater Discharge Permit and requirements of the Clean Water Act. During the first quarter of 1993, all liquid effluents from industrial processes complied fully with Federal pretreatment standards. Furthermore, the monitoring data at the site sewer outfall showed full compliance with permit limits for all parameters. 


\section{Compliance Summary}

Table 3-1. Major Federal Environmental Regulations Applicable to SNL/California.

\begin{tabular}{|c|c|}
\hline Legislation & Description \\
\hline $\begin{array}{l}\text { RCRA } \\
\text { Resource Conservation and Recovery Act }\end{array}$ & $\begin{array}{l}\text { Regulates hazardous, nonhazardous, and medical waste. It also } \\
\text { regulates underground storage tanks containing hazardous } \\
\text { substances and petroleum products. }\end{array}$ \\
\hline $\begin{array}{l}\text { CERCLA; SARA } \\
\text { Comprehensive Environmental Response, } \\
\text { Compensation, and Liability Act }\end{array}$ & \multirow[t]{2}{*}{$\begin{array}{l}\text { Establish liability, compensation, cleanup, and emergency response } \\
\text { for hazardous substances released to the environment. SNL/Californi } \\
\text { is not on the National Priority List. }\end{array}$} \\
\hline $\begin{array}{l}\text { Superfund Amendments and } \\
\text { Reauthorization Act }\end{array}$ & \\
\hline $\begin{array}{l}\text { SARA TITLE III; EPCRA } \\
\text { Emergency Planning and Community } \\
\text { Right-to-Know Act }\end{array}$ & $\begin{array}{l}\text { Require that hazardous substances used on-site be reported to State } \\
\text { and local governments and to the general public. }\end{array}$ \\
\hline $\begin{array}{l}\text { CWA; NPDES } \\
\text { Clean Water Act } \\
\text { National Pollutant Discharge Elimination } \\
\text { System }\end{array}$ & $\begin{array}{l}\text { Regulate liquid discharges at the end of each conveyance (e.g., drain } \\
\text { or pipe). Has been expanded to cover storm-water discharges from } \\
\text { industrial activities. }\end{array}$ \\
\hline $\begin{array}{l}\text { CAA; NESHAPs } \\
\text { Clean Air Act }\end{array}$ & \multirow{2}{*}{$\begin{array}{l}\text { Set air quality standards for hazardous air emissions, such as } \\
\text { radionuclides and benzene. }\end{array}$} \\
\hline $\begin{array}{l}\text { National Emission Standards for Hazardous } \\
\text { Air Pollutants }\end{array}$ & \\
\hline $\begin{array}{l}\text { TSCA } \\
\text { Toxic Substances Control Act }\end{array}$ & $\begin{array}{l}\text { Controls the use and exposure of new industrial chemicals. Also } \\
\text { regulates the use and disposal of polychiorinated biphenyls (PCBs) } \\
\text { and asbestos. }\end{array}$ \\
\hline $\begin{array}{l}\text { NEPA } \\
\text { National Environmental Policy Act }\end{array}$ & $\begin{array}{l}\text { Evaluates potential environmental impacts of Federal activities and } \\
\text { alternatives. }\end{array}$ \\
\hline
\end{tabular}




\section{Compliance Summary}

\section{Table 3-2. Projects Submitted to DOE in 1992 for NEPA Review.}

\begin{tabular}{ll}
\hline \multicolumn{1}{c}{ Project } & \multicolumn{1}{c}{ Description } \\
\hline Stereolithography* & System to produce prototype hardware for engineering evaluations. \\
LIDAR Testbed Project* & Laser diagnostics project, expanding existing on-site experimentation. \\
Vital Records Storage Building* & Small support structure for protecting and saving documents. \\
Asbestos Management FY92 & Continuing program to remove and dispose of asbestos. \\
Temporary Office Trailer & Support structure to house summer employees. \\
Temporary Office Trailer for Auditors & $\begin{array}{l}\text { Support structure to accommodate auditors from organizations outside cf } \\
\text { Sandia. }\end{array}$ \\
Maintenance Material Storage Facility & $\begin{array}{l}\text { Support structure to house chemicals and associated materials used by } \\
\text { the Maintenance Department. }\end{array}$ \\
Health Care Facility & Support structure to relocate the existing facility to another facility on-site. \\
Bus Turnaround* & $\begin{array}{l}\text { Relocation of the public bus turnaround from a high-traffic area to a low- } \\
\text { traffic area. }\end{array}$ \\
Bioremediation Pilot Study* & Pilot study for analysis of method to clean up on-site oil spill. \\
Air conditioning work-Bldg. 964 & Air conditioning equipment addition. \\
East Arroyo Seco Security Structure/Fence & Completion of the security fencing per DOE guidelines. \\
\hline
\end{tabular}

"These activities are designated as "Categorical Exclusions." Categorical Exclusions are defined as actions that do not individually or cumulatively have a significant effect on the quality of the human environment and require no further NEPA documentation.

\section{Table 3-3. SNL/California Bay Area Air Quality Management District Permitted Sources.}

\begin{tabular}{|c|c|c|c|}
\hline Source \# & Description & Location & Permit Condition \\
\hline $6 \& 7$ & Boilers \#1 \& 2 & Bldg. 907, CRF & $\begin{array}{l}\text { Space heat only; Sulfur content of fuel shall } \\
\text { not exceed } 0.5 \% \text { by weight }\end{array}$ \\
\hline 12 & $\begin{array}{l}\text { Incinerator (BAYCO reclamation } \\
\text { furnace multiple chamber) }\end{array}$ & Area 8 & No special conditions \\
\hline 16 & Paint Spray Booth & Bldg. 913, Room 130 & No special conditions \\
\hline 20 & Cold Cleaner & Bldg. 913, So. Shed & No special conditions \\
\hline 21 & Cold Cleaner & $\begin{array}{l}\text { Bldg. 963, East Shed. } \\
\text { Car Mechanics }\end{array}$ & No special conditions \\
\hline 22 & Boiler & Bldg. 916 NW & $\begin{array}{l}\text { Space heat only; sulfur content of fuel shall } \\
\text { not exceed } 0.5 \% \text { by weight }\end{array}$ \\
\hline $23 \& 24$ & Boilers $1 \& 2$ & Bldg. 9137 & $\begin{array}{l}\text { Space heat only; sulfur content of fuel shall } \\
\text { not exceed } 0.5 \% \text { by weight }\end{array}$ \\
\hline 25 & Boiler & Bldg. 912 SW & $\begin{array}{l}\text { Space heat only; sulfur content of fuel shall } \\
\text { not exceed } 0.5 \% \text { by weight }\end{array}$ \\
\hline $26 \& 27$ & Boilers $1 \& 2$ & Bldg. 968 & $\begin{array}{l}\text { Space heat only; sulfur content of fuel shall } \\
\text { not exceed } 0.5 \% \text { by weight }\end{array}$ \\
\hline $28 \& 29$ & Boilers $1 \& 2$ & Bldg. 910 & $\begin{array}{l}\text { Space heat only; sulfur content of fuel shall } \\
\text { not exceed } 0.5 \% \text { by weight }\end{array}$ \\
\hline
\end{tabular}




\section{Compliance Summary}

\section{Table 3-3. SNL/California Bay Area Air Quality Management District Permitted Sources (concluded).}

\begin{tabular}{|c|c|c|c|}
\hline Source \# & Description & Location & Permit Condition \\
\hline 30 & Gasoline Dispensing Facility & Bldg. 963 & No special conditions \\
\hline 33 & Vapor degreaser & Bldg. 910, Rm. 310B & Shall not exceed $100 \mathrm{gal} . / \mathrm{yr}$. AP.20 \\
\hline 34 & Vapor degreaser & Bldg. 910, Rm. 310F & Shall not exceed $100 \mathrm{gal} . / \mathrm{yr}$. TCE \\
\hline 35 & $\begin{array}{l}\text { Cold parts cleaner with solvent } \\
\text { recovery still }\end{array}$ & Bldg. 910, Rm. 310F & $\begin{array}{l}\text { Shall not exceed } 100 \text { gal./yr. methylene } \\
\text { chloride }\end{array}$ \\
\hline 36 & $\begin{array}{l}\text { Ultrasonic cleaner with vapor } \\
\text { recovery still }\end{array}$ & Bldg. 910. Penthouse & Shall not exceed $150 \mathrm{gal} . / \mathrm{yr}$. TCE \\
\hline 37 & $\begin{array}{l}\text { TRL; abated by Gas Purification } \\
\text { System (A-37) and Vacuum Effluent } \\
\text { Recovery System (A-38) }\end{array}$ & Bldg. 968 & $\begin{array}{l}\text { SNL shall maintain the GPS and VERS in } \\
\text { good operating condition }\end{array}$ \\
\hline 38 & Tritium wastewater evaporator & Bldg. 968 & No special conditions \\
\hline 49 & Monograph Offset Printing Press & Bldg. 911 & $\begin{array}{l}\text { Tuial amount of ink used shall not exceed } \\
30 \text { lbs. in any one-year period }\end{array}$ \\
\hline 55 & Decontamination sink & Bldg. 961 & No special conditions \\
\hline $56(A-56)$ & $\begin{array}{l}\text { Waste compactor abated by HEPA } \\
\text { filter }\end{array}$ & Bldg. 961 & No special conditions \\
\hline 60 & Drum crusher & Bldg. 961 & No special conditions \\
\hline 77 & Hexavalent Chromium Plating Bath & Bldg. 913 & $\begin{array}{l}\text { Net throughput not to exceed } 46,000 \\
\text { amp-hrs. in any one-year period }\end{array}$ \\
\hline 79 & Wipe cleaning operations & Bldg. 913 & Shall not exceed $207.2 \mathrm{lbs} . / \mathrm{yr}$. solvents \\
\hline $81 \& 82$ & Boiler 2 & Bldg. 940 & $\begin{array}{l}\text { Shall burn only natural gas, except during } \\
\text { times of natural gas curtailment }\end{array}$ \\
\hline 84 & Vapor degreaser & Bldg. 913, Rm. 119 & Shall not exceed 18 gal./yr. \\
\hline 85 & Ammonia-based etchant & Bldg. $910, \mathrm{Rm} .310$ & $\begin{array}{l}\text { Ammonium hydroxide usage shall not } \\
\text { exceed } 15 \text { gal./yr. }\end{array}$ \\
\hline 87 & Portable abrasive blaster & Bldg. 963 & $\begin{array}{l}\text { Visible emissions shall not exceed } \\
\text { Ringlemann } 0.5 \text {; shall not use more than } \\
10,000 \text { lbs./yr. of blasting material }\end{array}$ \\
\hline 89 & Abrasive blaster & Bldg. 969 & No special conditions \\
\hline 90 & Waste handling station & Bldg. 968 & $\begin{array}{l}\text { Annual process weight shall not exceed } \\
15.5 \text { tons }\end{array}$ \\
\hline 91 & Abrasive blaster & Bldg. 906 & No special conditions \\
\hline
\end{tabular}




\section{Compliance Summary}

Table 3-4. BAAQMD Exemptions Granted SNL/California in 1992.

\begin{tabular}{|c|c|c|}
\hline Source \# & Description & Location \\
\hline 9 & Machine Shop (abated by baghouse) & Bldg. 907, CRF \\
\hline 30 & Diesel fuel dispensing tank & Bldg. 907 \\
\hline 31 & Diesel fuel dispensing tank & Bldg. 963 \\
\hline 39 & Potassium gold cyanide plating operation & Bldg. 913, Rm. 118 \\
\hline 40 & Ultrasonic cleaner & Bldg. 961 \\
\hline 41 & Vapor-phase reflow soldering unit & Bldg. 910, Rm. 310B \\
\hline 42 & Traveling furnace & Bldg. 910, Rm. 308F \\
\hline 43 & Wipe-cleaning operation & Bldg. 916, Rm. 108F \\
\hline 44 & Plastics Laboratory oven & Bldg. 913, Rm. 124 \\
\hline 45 & Photo developing operations & Bldg. 913. Rm. 156 \\
\hline 46 & Low-pressure flat flame burner (abated by Venturi scrubber) & Bldg. 906, Rm. 108 \\
\hline 48 & AB Dick Offsel Printing Press & Bldg. 911 \\
\hline 50 & Explosive Test Cell & Bldg. 973 \\
\hline 51 & Explosive Test Cell & Bldg. 973 \\
\hline 52 & Trio-tech centrifuge & Bldg. 973 \\
\hline 53 & Spin Facility & Bldg. 976 \\
\hline 54 & Liquid propellant gun process & Bldg. 974 \\
\hline 57 & Foams Development Laboratory & Bldg. 913 \\
\hline 58 & Walk-in oven & Bldg. 913 \\
\hline 59 & Vacuum oven & Bldg. 913, South Shed \\
\hline 61 & Laser Chemistry Laboratory & Bldg. 916, Rm. 156 \\
\hline 62 & Chemical Dynamics Laboratory & Bldg. 906, Rm. 118 \\
\hline 63 & Cluster Chemistry Laboratory & Bldg. 916. Am. 158 \\
\hline 64 & Wipe-cleaning operation, Cluster Chemistry Laboratory & Bldg. 916, Rm. 158 \\
\hline 65 & Gas-phase Materials Synthesis Laboratory & Bldg. 906, Am. 308 \\
\hline 66 & Hybrid Microcircuit Laboratory, ammonia-based etching & Bldg. 910, Rm. 308 \\
\hline 67 & Hybrid Microcircuit Laboratory, micro pen printer & Bldg. 910, Rm. 308 \\
\hline 68 & Hybrid Microcircuit Laboratory, screen printer & Bldg. 910, Rm. 308 \\
\hline 69 & Hybrid Microcircuit Laboratory, dispatch oven & Bldg. 910, Rm. 308 \\
\hline 70 & Hybrid Microcircuit Laboratory, infrared oven & Bldg. 910, Rm. 308 \\
\hline 71 & Ultrafast Phenomena Laboratory & Bldg. 905, Rm. 120 \\
\hline 72 & Chemical Kinetics Laboratory, experiments & Bldg. 906, Rm. 103 \\
\hline 73 & Chemical Kinetics Laboratory, mixing operation & Bldg. 906, Rm. 103 \\
\hline 74 & Macromolecular Chemistry Laboratory, VWR oven & Bldg. 913, Rm. 128 \\
\hline 76 & Inorganic Synthesis and Vacuum Analytical Laboratory & Bldg. 916, Rm. 159 \\
\hline 83 & Instapack foam machine & Bldg. 928 \\
\hline 86 & Turbulent Combustion Laboratory & Bldg. 906, Rm. 114 \\
\hline
\end{tabular}




\section{Compliance Summary}

Table 3-5. Environmental Audits of SNL/California in 1992.

\begin{tabular}{lll}
\hline \multicolumn{1}{c}{ Date } & Regulatory Authority & \\
\hline $1 / 21-1 / 24$ & DOE/AL & Radiation protection and industrial hygiene appraisals \\
$1 / 14,2 / 24,3 / 6,5 / 4$, & BAAQMD & Air quality management inspections \\
$6 / 15,6 / 18,7 / 2,7 / 24$ & DOE/AL & Emergency management appraisal \\
$3 / 3-3 / 6$ & DOE/AL & Packaging and transportation appraisals \\
$3 / 9-3 / 17$ & DOE/KC & QA survey of H1501A Program \\
$3 / 16-3 / 19$ & LWRP & Livermore Water Reclamation Plant inspections \\
$4 / 2,5 / 28$ & DOE/AL & KAO oversight safety inspection \\
$6 / 22-6 / 24$ & Cal-EPA DTSC & Toxic substance control inspection \\
$6 / 30-7 / 2$ & DOE/AL & Classification appraisals \\
$7 / 28-7 / 29$ & DOE/NV & Radioactive waste management audit \\
$7 / 28-7 / 29$ & DOE/AL & Nuclear Explosive Safety Program appraisal \\
$7 / 30$ & DOE/AL & Waste Managment Operational Surety Division (WMOSD) \\
$8 / 31$ & DOE/AL & Waste Management Program review \\
$9 / 2-9 / 3$ & DOE/AL & KAO oversight safety inspection \\
$9 / 8-9 / 11$ & DOE/AL & Conduct of Operations performance review \\
$9 / 9-9 / 11$ & DOE/HQ & Environmental restoration assessment \\
$9 / 14-9 / 15$ & DOE/AL & Annual Waste Operations Program evaluation \\
$12 / 7-12 / 11$ & DOE/AL & Environmental Monitoring and Air Programs-Radiation \\
$12 / 7-12 / 11$ & DOE/KAO & ES\&H oversight visit \\
$12 / 14-12 / 18$ & &
\end{tabular}

Table 3-6. Corrective Actions Taken by SNL/California in 1992.

\begin{tabular}{|c|c|c|c|}
\hline Date & $\begin{array}{l}\text { Issuing } \\
\text { Agency }\end{array}$ & Description of Violation & DOE/SNL Response \\
\hline $2 / 24 / 92$ & BAAQMD & Paint Shop violations & $\begin{array}{l}\text { Paint was inventoried; Sandia quit using paints thal } \\
\text { do not meet BAAQMD standards. }\end{array}$ \\
\hline $8 / 28 / 92$ & DTSC & $\begin{array}{l}\text { Waste gerierator labeling violation- } \\
\text { incomplete information on label }\end{array}$ & Label was completed. \\
\hline $8 / 28 / 92$ & DTSC & $\begin{array}{l}\text { Waste generator labeling violation- } \\
\text { incomplete information on label }\end{array}$ & Label was completed. \\
\hline $8 / 28 / 92$ & DTSC & Open waste container & Container was closed. \\
\hline $8 / 28 / 92$ & DTSC & $\begin{array}{l}\text { Manifest file lacked land disposal } \\
\text { restriction forms }\end{array}$ & $\begin{array}{l}\text { The land disposal restriction forms were completed } \\
\text { at the time of shipment; not a violation. }\end{array}$ \\
\hline $8 / 28 / 92$ & DTSC & Inadequate aisle space & $\begin{array}{l}\text { The SNL Legal Department is negotiating this issue } \\
\text { with the DTSC. }\end{array}$ \\
\hline
\end{tabular}




\section{Compliance Summary}

Table 3-7. Environment-related Occurrence Reports.

\begin{tabular}{|c|c|c|c|}
\hline Report No. & Date & Subject & $\begin{array}{c}\text { Occurrenc } \\
\text { Categor } \\
\end{array}$ \\
\hline $\begin{array}{l}\text { ALO-KO-SNL } \\
\text { LVMRSITE- } \\
\text { 1992-0004 }\end{array}$ & $2 / 26 / 92$ & $\begin{array}{l}\text { Two violations } \\
\text { issued by } \\
\text { BAAQMD }\end{array}$ & Off-normal \\
\hline $\begin{array}{l}\text { ALO-KO-SNL } \\
\text { LVMRSITE- } \\
\text { 1992-0007 }\end{array}$ & 4/28/92 & $\begin{array}{l}\text { Radiological } \\
\text { source found in } \\
\text { the scrap yard } \\
\text { area }\end{array}$ & Off-normal \\
\hline
\end{tabular}

ALO-KO-SNL 5/15/92

( sontamina-

tic 1 of ground in

Off-normal

1992-0008

scrap yard area

$\begin{array}{lll}\text { ALO-KO-SNL } & 6 / 3 / 92 & \begin{array}{l}\text { Hazardous } \\ \text { material deli- } \\ \text { LVMRSITE- } \\ \text { vered to off-site } \\ \text { scrap yard }\end{array}\end{array}$

ALO-KO-SNL

$5 / 28 / 92$

Tritium release Off-normal TRL-19920001

due to equipment failure

\begin{tabular}{|c|c|c|}
\hline $\begin{array}{l}\text { ALO-KO-SNL } \\
\text { LVMRSITE- } \\
1992-0002\end{array}$ & $6 / 1 / 92$ & $\begin{array}{l}\text { Tritium release } \\
\text { due to } \\
\text { equipment } \\
\text { failure }\end{array}$ \\
\hline
\end{tabular}

\section{Description of Occurrence}

The violations were issued to the Paint Shop spray booth because: 1) no current list of coatings was available and 2) coatings used were not in compliance with BAAQMD regulations. The list of coatings was revised to address these issues, and a root cause analysis was done. A final occurrence report has yet to be issued.

A BB-sized pellet containing cesium-137 was discovered embedded in the asphalt in the metal reclamation yard during a routine scrap metal survey, before pickup by a scrap metal recycler. The pellet had a dose rate of 20 milliroentgens per hour ( $\mathrm{mR} / \mathrm{hr}$ ) at contact and $0.15 \mathrm{mR} / \mathrm{hr}$ at one foot. Inventory records indicate the pellet could have been at least 25 years old. The pellet could have rolled out of a scrap metal vendor's truck or it could have been left from Naval operations. It was bagged and returned to the lab for analyses, then placed in a lead container to be transported to Bldg. 961 for disposal. This incident did not result in any personnel exposure or contamination of the environment.

When an excess electrical component was being moved offsite by a subcontractor using a Bobcat tractor, the tines on the tractor punctured two holes in the bottom of the unit. Approximately 3 gallons of PCB-contaminated oil spilled onto the surrounding asphalt and dirt. Cleanup operations began after results of the $P C B$ tests indicated that the oil contained less than one pound of PCBs (the EPA's reportable limit).

Two environmental chambers, which Sandia had delivered to a contractor who had purchased them as salvage, contained asbestos, discovered by the contractor. The asbestos was in non-friable form and posed no immediate danger to people or the environment. The asbestos was removed from the chambers and disposed of at a Class I landfill.

While the Sandia Thermal Outgassing Experiment (STOX) was being reconfigured, a small amount of tritium (approximately $4 \mathrm{Ci}$ ) was released into the atmosphere. The incident occurred after a $1000-\mathrm{Ci}, 800$-psi bottle of $99 \%$ deuterium $/ 1 \%$ tritium gas mixture was attached to the system. After the stack monitor indicated a slight increase in the tritium level of the air in the stack, the TRL staff determined that the attachment was leaking. While they were retorquing the bottle side of the attachment, a small amount of tritium was released. The tritium left in the tubing was evacuated from the system into the Vacuum Effluent Recovery System (VERS), and the gaskets were replaced in the fittings. The amount of tritium released caused no harm to people or the environment.

On 6/1/93, the TRL stack monitoring system detected a release of $36 \mathrm{Ci}$ tritium to the stack from the STOX. The sys tem was evacuated through the VERS to remove the tritium. The experimental system was reconfigured to protect all components in the system. The amount of tritium released caused no harm to people or the environment. 


\section{Compliance Summary}

Table 3-8. SNL/California Environmental Permits in 1992.

\begin{tabular}{|c|c|c|}
\hline Category & Regulation/Authority & Permit Status \\
\hline Waste Management & $\begin{array}{l}\text { Title } 40 \text { CFR } 264 \text { (RCAA), EPA; } \\
\text { Title } 22 \text { CCR, Division } 4.5 \\
\text { DTSC }\end{array}$ & $\begin{array}{l}1983 \text { RCRA Part B permit expired 12/88. Renewal filed 6/88. } \\
\text { During } 1992 \text {, SNL/California operated under interim status. } \\
\text { New Part B permit is effective January 4, 1993. See Hazar- } \\
\text { dous Waste Permits for more information. }\end{array}$ \\
\hline Waste Management & $\begin{array}{l}\text { Medical Waste Management } \\
\text { Act }\end{array}$ & $\begin{array}{l}\text { Obtained a permit from Alameda County, Department of } \\
\text { Environmental Health, to incinerate biomedical waste on-site. }\end{array}$ \\
\hline Waste Management & 22 CCR, Division 4.5, DTSC & $\begin{array}{l}\text { Extremely Hazardous Waste Permits for transporting hazardous } \\
\text { waste off-site. Three were issued in 1992: 07/10/92-\#2-16031; } \\
09 / 24 / 92-\# 2-17280 \text {; and } 11 / 13 / 92-\# 2-17417 \text {. }\end{array}$ \\
\hline Air Quality & BAAQMD & $\begin{array}{l}\text { BAAQMD permits for } 35 \text { air emission sources. Permits renewed } \\
\text { annually (see Table 3-3). }\end{array}$ \\
\hline Air Quality & $\begin{array}{l}\text { Title } 40 \text { CFR } 61 \text { (NESHAPs), } \\
\text { EPA }\end{array}$ & $\begin{array}{l}\text { This permit was issued by the EPA under the National Emission } \\
\text { Standards for Hazardous Air Pollutants (Title } 40 \text { CFR } 61 \text {, } \\
\text { Subpart H) to operate a low-level tritium evaporator at the TRL. } \\
\text { Trial run was completed; the operation was approved. }\end{array}$ \\
\hline Wastewater Discharge & $\begin{array}{l}\text { City Ordinance, City of } \\
\text { Livermore }\end{array}$ & $\begin{array}{l}\text { Permit for the site sanitary and industrial wastewater discharge. } \\
\text { Permit renewed annually. }\end{array}$ \\
\hline Storm Water Discharge & $\begin{array}{l}\text { Clean Water Act (Title } 40 \text { CFR } \\
\text { 122-124), National Pollutant } \\
\text { Discharge Elimination System } \\
\text { (NPDES), EPA }\end{array}$ & $\begin{array}{l}\text { In March 1992, SNL/California filed a Notice of Intent with the } \\
\text { State Water Resources Control Board. Sandia is covered by the } \\
\text { State's NPDES General Permit for Discharge of Storm Water } \\
\text { Associated with Industrial Activities. }\end{array}$ \\
\hline
\end{tabular}




\section{4 - Environmental Monitoring Program Information}

Effluent Monitoring Results Meteorological Monitoring Results

Environmental Surveillance Results 


\section{Environmental Monitoring Program Information}

The Environmental Protection Department at SNL/California (in conjunction with LLNL) maintains an effluent monitoring and environmental surveillance program. This program's purpose is to assess and control potential impacts, if any, to the public and the environment from operations at SNL/California. The department monitors all significant liquid and airborne effluents, making sure SNL/Californiaa continually complies with environmental protection laws and standards. Environmental surveillance verifies the effectiveness of emission control measures by routinely examining environmental media, such as ambient air, surface water, groundwater, soil, arroyo sediments, storm-water runoff, sewage, vegetation, and locally-produced foodstuffs, for radionuclides and hazardous chemicals that may be emitted from site operations. An extensive environmental dosimeter network also measures external radiation levels. SNL/California's joint environmental monitoring activities with LLNL ensure that all significant exposure pathways are monitored. Table 4-1 shows the types and number of samples collected, the collection frequency, and the parameters measured.

This chapter discusses the results of SNL/California and LLNL's joint monitoring activities. The monitoring data are interpreted and evaluated according to applicable standards. Appendix A briefly describes the laboratory analyses done on the samples.

\section{Effluent Monitoring Results}

\section{Airborne Effluents}

The only detectable radionuclide discharged to the atmosphere from operations at SNL/California was tritium from the TRL. ${ }^{25}$ In 1992, a total of $264 \mathrm{Ci}$ tritium was discharged. Of this amount, $134 \mathrm{Ci}$ was in the form of iritium oxide ( $\mathrm{HTO}$ or $\mathrm{T}_{2} \mathrm{O}$ ), and the remaining $130 \mathrm{Ci}$ was in the form of elemental tritium gas ( $\mathrm{HT}$ or $\mathrm{T}_{2}$ ). Based on tilese stack emissions, the radiological dose to a maximally exposed member of the public was determined. EPA-approved assessment models were used to calculate potential off-site doses. The methods and results of this assessment are presented in Chapter 5, "Environmental Impacts." Figure 4-1 shows the tritium releases for both SNL/California and LLNL since 1982.

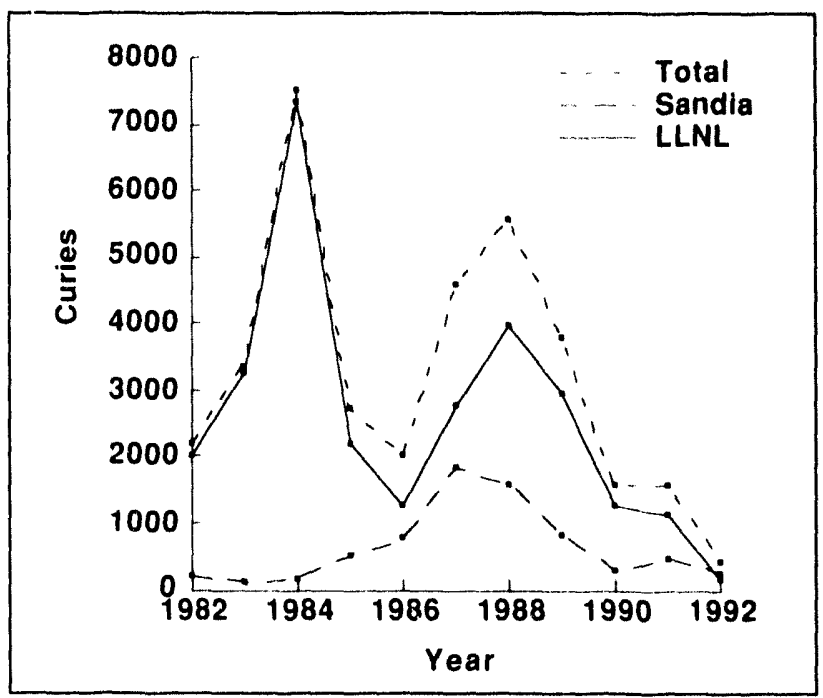

Figure 4-1. Tritium release's for both SNL/Californin and LLNL. sinc' 1982.

Emissions of nonradiological pollutants are regulated by operating permits obtained from the BAAQMD. These permits set operating conditions or limitations. $\mathrm{SNL} /$ California has no sources that require routine emission monitoring for nonradiological pollutants. Table 3-3 lists the air discharge permits held by SNL/California in 1992. 


\section{Environmental Monitoring Program Information}

\section{Liquid Effluents}

SNL/California's Liquid Effluent Control

Program ensures that liquid effluents generated by SNL/California operations comply with applicable regulations.

Wastewater discharge limits are imposed by DOE, ${ }^{3}$ the City of Livermore (Appendix C), and other State and Federal agencies. SNL/California continually strives to reduce pollutants in liquid effluents to the lowest levels possible.

In 1982, the EPA National Pretreatment Program provisions of the Clean Water Act established liquid effluent monitoring requirements for specific pollutants. ${ }^{\text {th }}$ Accordingly, SNL/California's Liquid Effluent Control Program emphasizes controlling effluents at the source.

SNL/California imposes strict administrative and engineering controls to prevent contaminated liquid discharge to the sanitary sewer system.

Potentially contaminated liquid effluents from SNL/California operations are contained in holding tanks in order to allow analyses to be performed on the wastewater before it is released to the sanitary sewer. If the contents of the tanks are found to exceed discharge limits, the liquids are disposed of as hazardous waste. In addition to this monitoring at the source, extensive monitoring is done on the sanitary sewer effluent before it leaves the $\mathrm{SNL} /$ California site.

In addition to the monitoring performed by SNL/California, the effluent at the LLNL sewer outfall is also extensively monitored, to include continuous monitoring for metals, $\mathrm{pH}$, flow, and gamma radiation. This continuous monitoring is supplemented by flow'-proportional grab samples, which are analyzed daily for gross alpha activity, gross beta activity, and tritium. These composite grab samples are also analyzed monthly for selected metals, organics, and physical parameters. Daily grab samples from the LWRP effluent are analyzed for gross alpha activity, gross beta activity, and tritium. Liquid effluent discharges are analyzed according to applicable regulations governing discharges to a POTW. These regulations include:

- DOE Order 5400.5 regulating radionuclide discharges to public sewer systems, ${ }^{3}$

- F.'A Categorical Pretreatment Standards, ${ }^{16}$ and

- City of Livermore wastewater discharge limits (Appendix B).

\section{Liquid Effluent Control Systems Description}

Potentially hazardous liquid effluents generated at SNL/California facilities are controlled at the source. These effluents are routed to Liquid Effluent Control Systems (LECS). LECS consist of large, monitored holding tanks, which collect the wastewater, allowing it to be analyzed before being released to the sanitary sewer. By retaining the wastewater at the point of generation, SNL/California can ensure it is within allowable limits before discharge and also prevent accidental releases to the sanitary sewer system. If it is determined that the contents of the tank contain pollutants above the discharge limits of the LWRP, then the liquid is considered a hazardous waste, and is disposed of in accordance with applicable regulations. 


\section{Environmental Monitoring Program Information}

\section{LECS Locations}

Figure 4-2 shows the locations of all of the LECS at the SNL/California site.

Bldg. 968--all floor drains and laboratory sinks in the TRL are routed to two 2500gallon tanks.

Bldg. 913-process wastewater from the central and southern portions of Bldg. 913 and from laboratories in BIdg. 916 is routed to a LECS consisting of three tanks.
Bldg. 910-process wastewater is routed from the Printed Wiring Laboratory to a LECS consisting of three tanks.

Bldg. 961-water from decontamination operations is routed to a LECS.

Blitg. 906-process wastewater is routed to a LECS.

Bldg. 941-The IMTL and its associated LECS were completed in 1992. The LECS comprises two tanks.

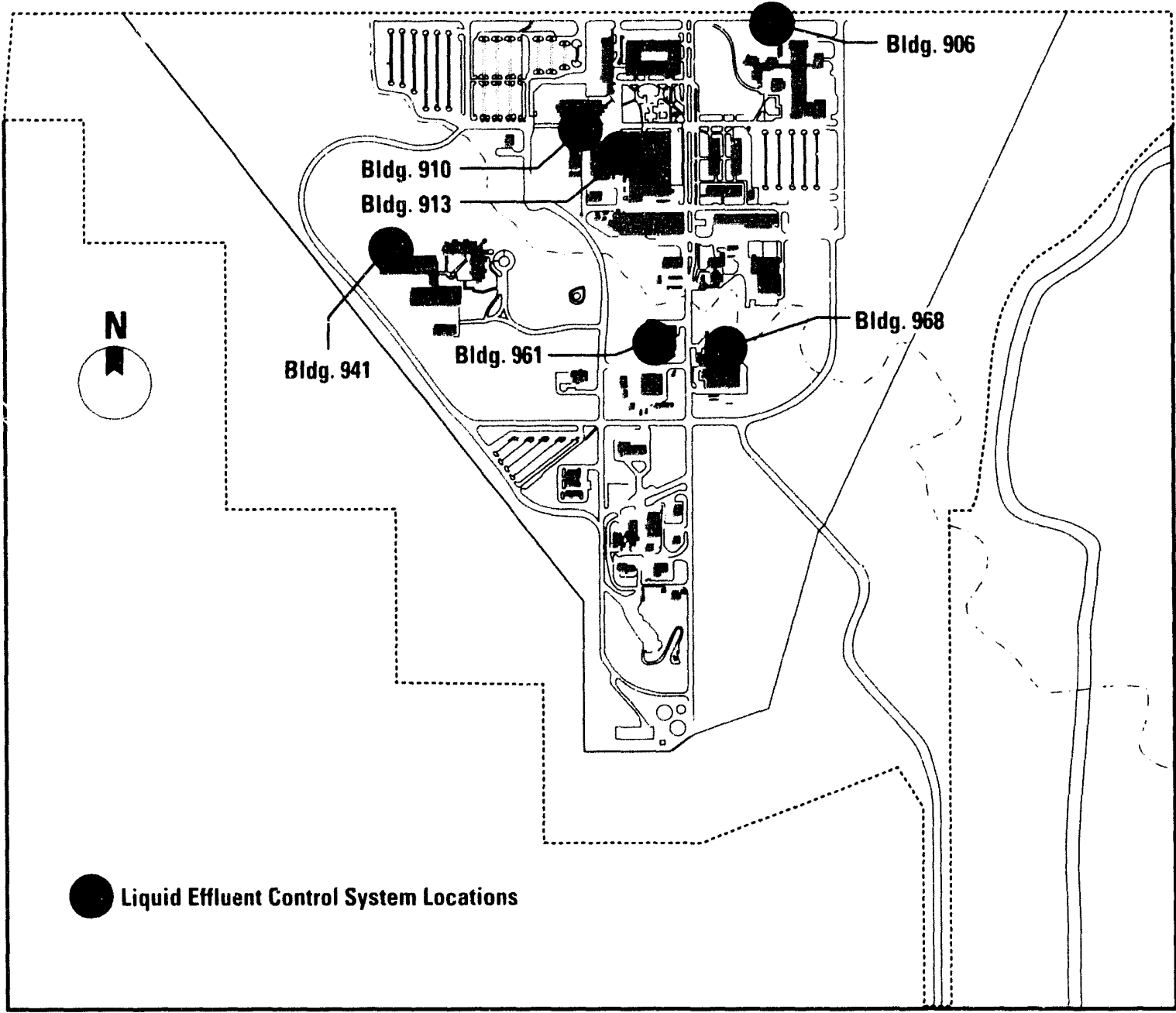

Figure 4-2. SNL/Califormin Liquid Ffflucht Control Systems (LECS). 


\section{Environmental Monitoring Program Information}

\section{Methods}

To assure that a representative sample is collected, the contents of the tanks are agitated by recirculation or air bubbling before they are sampled.

\section{Analyses}

The contents of the LECS are analyzed by Environmental Protection Department personnel using equipment owned and maintained by SNL/California's Inorganic and Physical Chemistry Department and Environmental Technology Program. The analyses done on the LECS samples are based on the particular processes generating the wastewater that feeds the LECS (see Table 4-2).

\section{Federal Categorical Processes}

\section{Description}

SNL/California operates two "categorical processes" subject to the Federal Pretreatment Standards (Title 40 CFR, Part 433)2: the Electroplating Laboratory in Bldg. 913 and the Printed Wiring Laboratory in Bldg. 910. Twice a year, special sampling procedures are conducted for these facilities' effluents. An independent laboratory analyzes the samples for regulated metals and EPA priority pollutants. The results indicate that all discharges from categorical processes were within Federal pretreatment standards.

\section{Analyses}

To comply with the requirements of the Federal Y'retreatment Standards, the effluents from these processes are sampled semiannually and analyzed for $\mathrm{pH}$, oil and grease, dissolved solids, oxygen demand, $\mathrm{As}, \mathrm{Cd}, \mathrm{Cr}, \mathrm{Cu}, \mathrm{Pb}, \mathrm{Hg}, \mathrm{Ni}, \mathrm{Ag}, \mathrm{Zn}, \mathrm{CN}^{-}$, and total toxic organics (TTO). The TTO analysis covers all EPA priority organic pollutants. These analyses are performed by a certified commercial laboratory.

\section{Results}

Table 4-3 presents the data for the semiannual monitoring of the categorical processes. The data indicate that all pretreatment standards were met during the 1992 sampling. These data are reported in the SNL/California Categorical Process Report submitted semiannually to the LWRP. ${ }^{26}$

\section{Sewer Outfall Monitoring}

Sandia monitors its sanitary sewer effluent before it exits the site and joins with the sanitary sewer flow from LLNL. The monitoring consists of continuous, grab, and flow-proportional composite sampling.

\section{Locations}

Samples are collected at the site sewer outfall. When the IMTL was built, the sanitary sewer outfall and its associated monitoring station were relocated (Fig. 4-3). The monitoring equipment was also upgraded.

\section{Methods}

The site sewer effluent is continuously monitored for flow and $\mathrm{pH}$ using real-time monitoring instruments. Grab samples are taken from the effluent stream before it reaches the automatic samplers and monitors. Flow-proportional samples are collected by an automatic, refrigerated, ISCO inline sampler. An archive sample that is representative of the daily sewer discharge is retained for use if confirmatory analyses are required. 


\section{Environmental Monitoring Program Information}

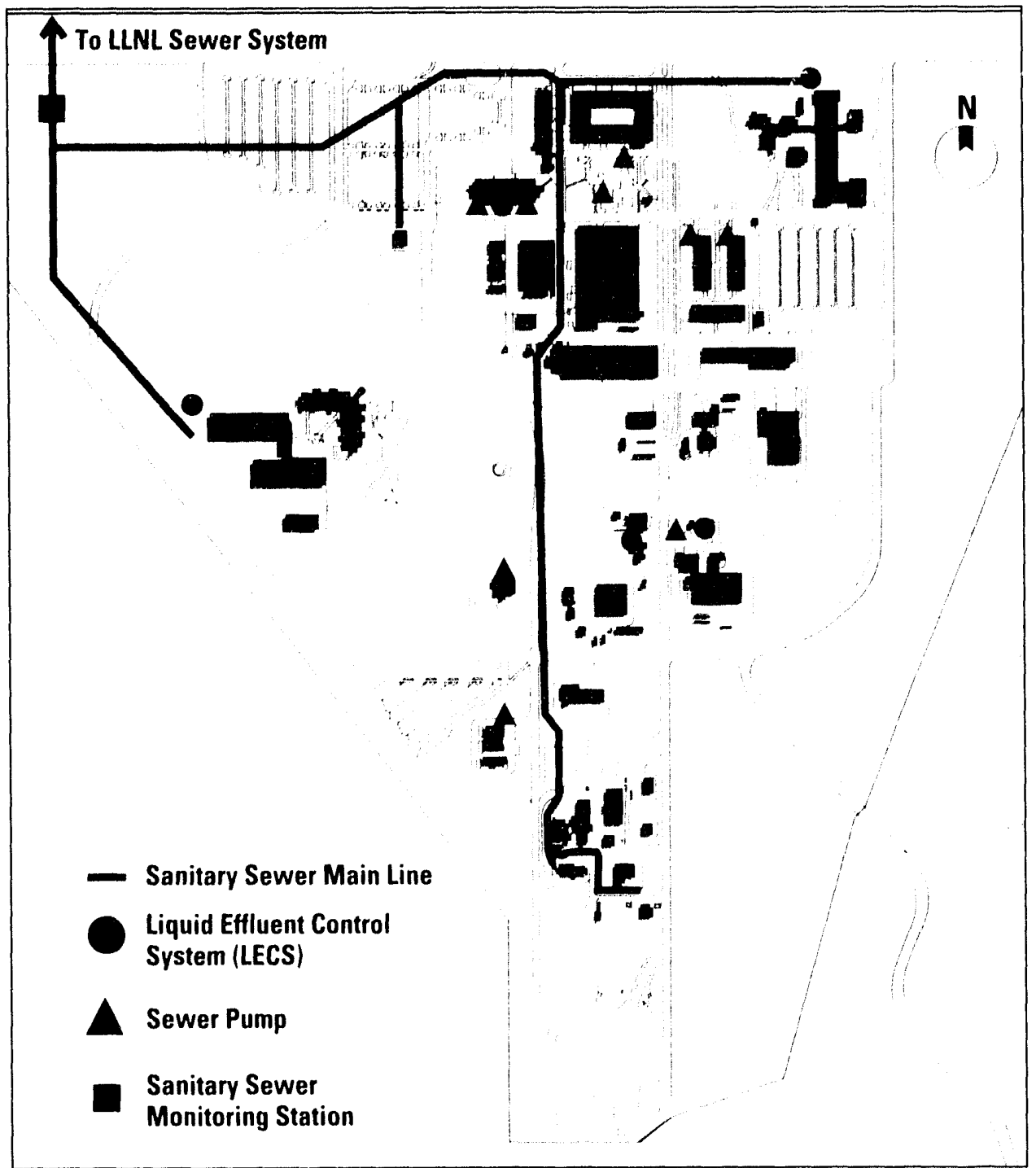

Figure 4-3. SNL/Californin

sanitary sezer system.

\section{Analyses}

SNL/California's sanitary sewer effluent is monitored to demonstrate compliance with discharge limits contained in Sandia's Wastewater Discharge Permit. The effluent is continuously monitored at the site sewer outfall for $\mathrm{pH}$ and flow. A flow-proportional composite sampler continuously samples the sewer effluent. The composite sample is collected weekly and sent to a State-certi- fied laboratory for analysis. The weekly composite sample is analyzed for regulated metals, $\mathrm{pH}$, total suspended solids, total dissolved solids, oxygen demand, and tritium. Grab samples are collected weekly and analyzed for cyanide and oil and grease. The sewer outfall sample is analyzed monthly for EPA priority organic pollutants (EPA Methods 624, 625, and 608). All of these analyses are done by a State- 


\section{Environmental Monitoring Program Information}

certified laboratory. The results are tabulated in a Wastewater Discharge Compliance Report, which is submitted to the LWRP monthly.

\section{Quality Assurance}

A portion of each composite sample is kept as an archive sample. This archive sample is analyzed in case the routine composite sample shows unusual concentrations of any parameter of concern. The data from analysis of the archive sample are used to validate the data from the routine sample.

\section{Results}

Tables 4-4 through 4-6 present the data for the 1992 sewer effluent monitoring.

DOE and the State of California have established allowable limits for discharging radionuclides to public sewer systems. A limit of $1 \mathrm{Ci} / \mathrm{yr}$. total radioactivity has been established to protect public health and the environment. In 1992, tritium was the only radionuclide in measurable amounts discharged to the sanitary sewer system. A total of $0.061 \mathrm{Ci}$ tritium was discharged$6 \%$ of the State's allowable discharge limit.

\section{Meteorological Monitoring Results}

Meteorological data are continuously collected at one meteorological monitoring station at the SNL/California site. These data are representative of the atmospheric conditions at the site. This information is required for assessing the transport, diffusion, and deposition of materials released to the atmosphere. The 1992 data include wind speed, wind direction, and ambient temperature.

\section{Monitoring Methods}

Sandia maintains a meteorological tower on the western portion of the site (Fig. 4-4). This location is representative of the local terrain and is clear of any obstructions to wind-flow patterns. The meteorological monitoring system is part of the Atmospheric Release Advisory Capability (ARAC), a DOE-operated network of monitoring stations designed to provide information to emergency response personnel. ARAC provides 24 -hour access to trained assessors and computer models to evaluate atmospheric dispersion and calculate doses from accidental releases of radioactive or hazardous materials.

The SNL/California tower is equipped with HANDAR model 540 instruments (as required by the ARAC system). Measurements of wind speed, wind direction, and temperature are made at heights of 10 meters and 40 meters. Measurements are taken every 3 seconds by the tower sensors. These data are compiled and stored as 15 -minute averages.

\section{Results}

The average 1992 surface wind speed and direction (10-meter tower level) measured at SNL/California are plotted in a wind rose (Fig. 4-5). The wind rose graphically illustrates annual average wind flow patterns. It is a circle with lines extending from the center. These lines represent the direction from which the wind blows. The length of the lines is proportional to the frequency of the particular wind-speed interval. Each line represents one of the 16 primary compass directions (N, NNE, etc.) and is centered on a 22.5-degree-wide sec- 


\section{Environmental Monitoring Program Information}

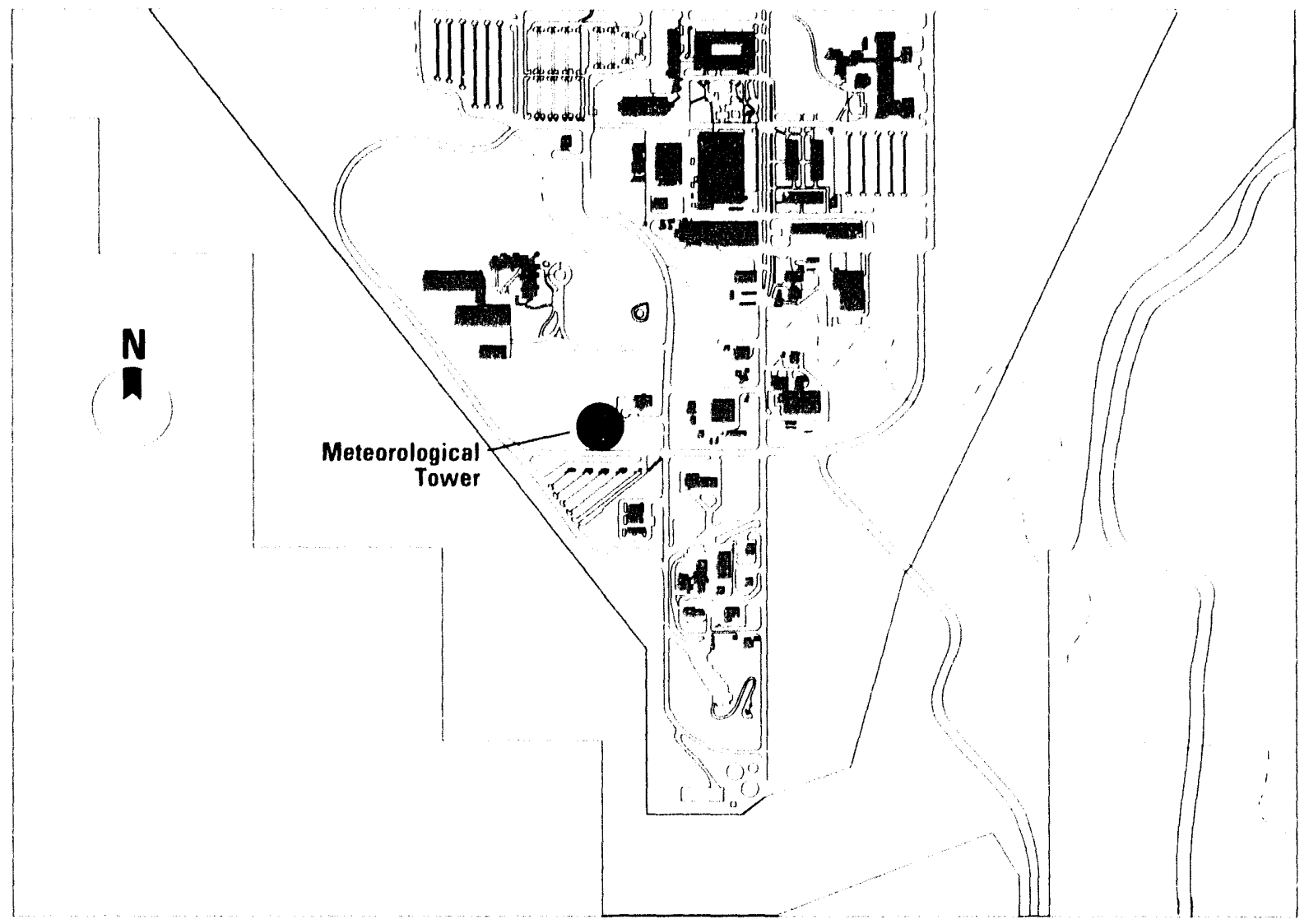

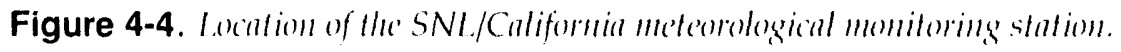

tor. The frequency of calm winds, defined as those less than $0.5 \mathrm{~m} / \mathrm{s}(1.1 \mathrm{mph})$, was $17.6 \%$, as indicated at the bottom of the figure. Table 4-7 provides the average annual percent frequency of wind direction vs. wind speed. These measurements are based on one-hour averages at the 10-meter tower level.

\section{ENVIRONMENTAL SuRVEILLANCE REsULTS}

\section{Ambient Air Monitoring}

Air is a primary exposure pathway to humans from radionuclides released to the atmosphere. Therefore, environmental air sampling is conducted to evaluate potential doses from inhaled or ingested radionuclides. The inhalation of airborne radionuclides, either directly or from resuspension following deposition, may result in their being absorbed into the body from the lung or GI tract. Skin absorption can also be a significant route of uptake for tritium.

\section{Description}

The ambient air monitoring system consists of sampling stations at the site perimeter and throughout the Livermore Valley. This design enables discrimination between 


\section{Environmental Monitoring Program Information}

Figure 4-5. Wind rose showing the average annual wind direction and speed during 1992.

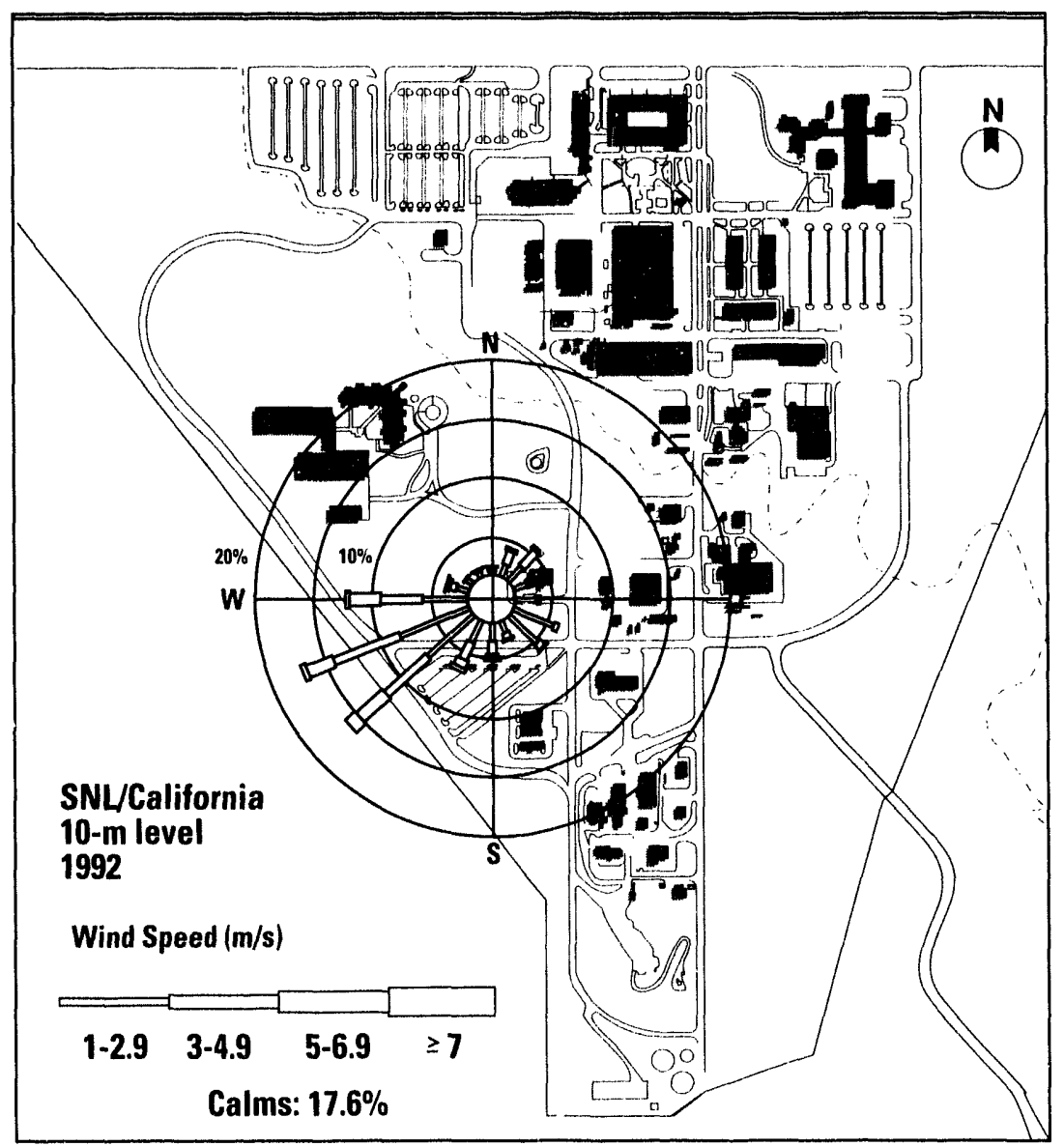

radionuclides from site operations and from background sources. If radionuclide concentrations at the perimeter monitoring stations are higher than Valley stations, they are assumed to be due to site emissions. The Valley locations also serve to monitor concentrations of radionuclides at local population centers.

Ambient air is the primary exposure pathway to the public from pollutants emitted from SNL/California operations. The potential emissions of concern are ${ }^{238} \mathrm{U}$ and tritium. ${ }^{238} \mathrm{U}$ is collected as a particulate, and tritium is collected as tritiated water vapor. More extensive analyses are per- formed on the air filters in order to monitor the impacts of LLNL operations, which include a greater range of radionuclides. Measurements of gross alpha and gross beta activity are used for screening purposes. The shorter time required for these analyses (as opposed to the radionuclide specific analyses) would provide more immediate indications of a significant increase in the uranium activity. The ratio of the uranium isotopes ${ }^{235} \mathrm{U} /{ }^{238} \mathrm{U}$ is measured in order to determine the origin of the uranium. The isotopic ratio of uranium used at the Livermore site is different from that found in nature (uranium is naturally 


\section{Environmental Monitoring Program Information}

found in soil and in air due to suspension of surface soils). Uranium used at $\mathrm{SNL} /$ California is in the form of depleted uranium (uranium that has had most of the ${ }^{235} \mathrm{U}$ removed). Therefore, if the air filters show less ${ }^{235} U$ than is expected in naturally occurring soils (approximately $0.7 \%$ ), the source of the uranium is probably site operations.

\section{Locations}

The site perimeter (near-field) sampling locations maintained by LLNL and the three air tritium samplers maintained by SNL/California are shown in Fig. 4-6. The off-site (distant) locations maintained by LLNL are shown in Fig. 4-7. Locations VET, CAFE, SALV, XRDS, ZON7, ALTA, LCCY, FIRE, HOSP, and SANDIA 1 through 4 are the locations most pertinent to the

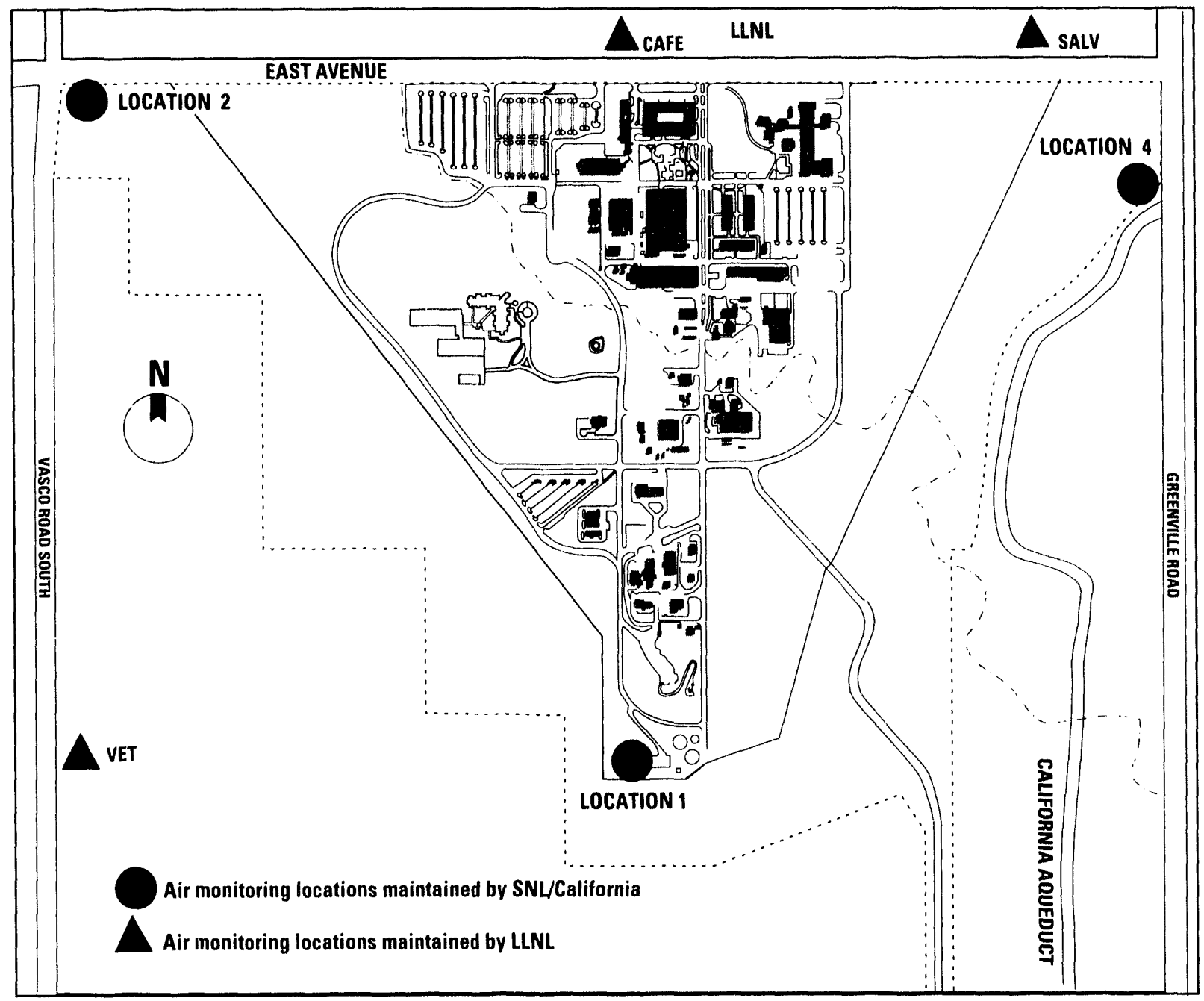

Figure 4-6. SNL/Californin site perimeter ambient air monitoring locations. 


\section{Environmental Monitoring Program Information}

Figure 4-7. Air sampling locations, Livermore Valley.

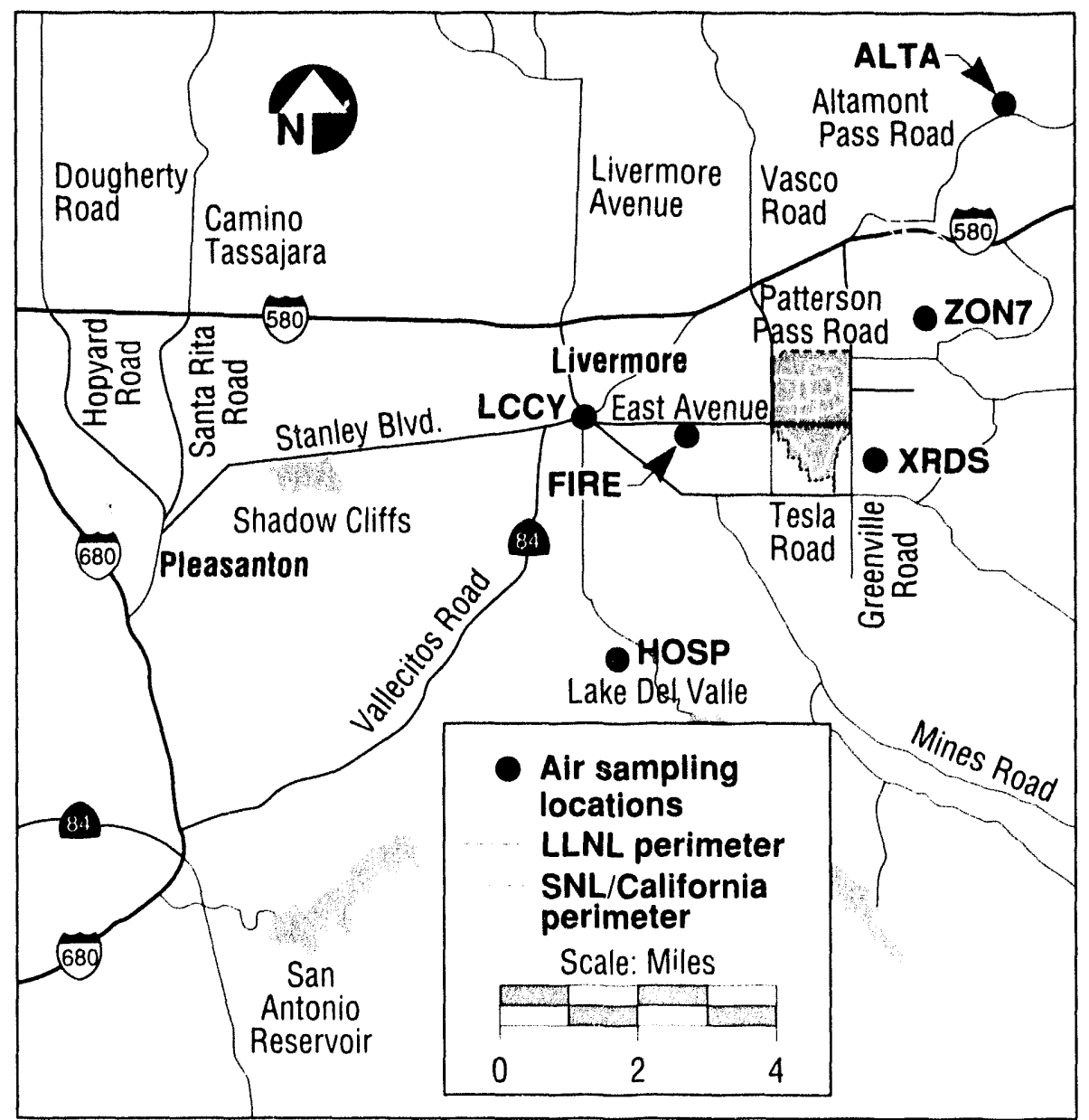

SNL/California site. Other air monitoring locations (not shown) serve primarily to monitor LLNL operations. Table G-4, in the Glossary (p. GLS-12), lists the sampling location designators.

\section{Methods}

Air particulates are collected by General Metal Works high-volume air samplers. The filters used are Whatman \#41 filters with an area of $0.052 \mathrm{~m}^{2}$. These filters are used as a good balance between particulate collection efficiency and the need for an easily dissolved, low-metal-content filter.
The flow rate of the sampler is maintained at $400 \mathrm{~L} / \mathrm{min}$. by a mass flow controller. At the end of the one-week collection period, the flow rate and run time are used to calculate the volume of air sampled. Monthly composites of the weekly samples from locations CAFE and SALV are analyzed for $235 \mathrm{U}, 238 \mathrm{U}$, gross alpha, and gross beta. Samples from locations VET, XRDS, ZON7, ALTA, LCCY, FIRE, and HOSP are analyzed for gross alpha and gross beta emitters.

LLNL air tritium samples are collected at locations CAFE, SALV, VET, XRDS, MESQ, MET, VIS, COW, ZON7, ALTA, 


\section{Environmental Monitoring Program Information}

FIRE, and LCCY. These samples are collected by pumping ambient air through a glass flask containing silica gel at a flow rate of $0.7 \mathrm{~L} / \mathrm{min}$. The flow is set to this rate when collection is started, the flow at the end of the two-week collection period is noted, and the average of the two flow rates is used to calculate the total volume of sample collected.

SNL/California air tritium samplers are able to discriminate between HTO and HT. The sampled air first is passed through ethylene glycol to remove the HTO, then passed over a catalyst to oxidize HT to HTO, which is then also collected in ethylene glycol. Additional air tritium samples are collected on the LLNL site to assess local impacts from specific operations.

\section{Quality Assurance}

One high-volume air particulate sampler is used as a duplicate sampler. This sampler is moved to a different LLNL perimeter location every month and run in parallel with the normal sampler. The filter from this sampler is analyzed for the same parameters as the normal sampler. One air tritium sampler is also run as a duplicate sampler at an LLNL site perimeter location. This sampler is also moved monthly. These duplicate samplers serve as the basis for determining the precision of the sampling and analytical system. Accuracy of the analytical system is assessed by the analysis of reference materials provided by DOE or EPA (for air filters), or by analysis of spiked pseudosamples which have been prepared with standards traceable to National Institute of Standards and Technology (NIST). Blank air filters are processed as a check on possible contamination. Blank sili- ca gel samples are created by bubbling tap water onto a silica gel sampler and then analyzing it for the required constituents.

\section{Results}

Table 4-8 contains the air concentrations of $238 \mathrm{U}$ near the SNL/California site perimeter. The highest annual average ${ }^{238} \mathrm{U}$ concentration was $8.42 \times 10^{-5} \mu \mathrm{g} / \mathrm{m}^{3}$, i.e., $0.61 \%$ of the DCG (see Table D-1). Figure 4-8 shows the highest annual average uraniumin-air concentrations at the Livermore site perimeter for 1987-92. Except for the higher concentration in 1988, the uranium concentrations appear to be fairly constant and follow no significant trend. The concentrations detected are within the range to be expected from natural background sources. The $235 \mathrm{U} / 238 \mathrm{U}$ isotopic ratios also indicate that the uranium in the samples is from natural background.

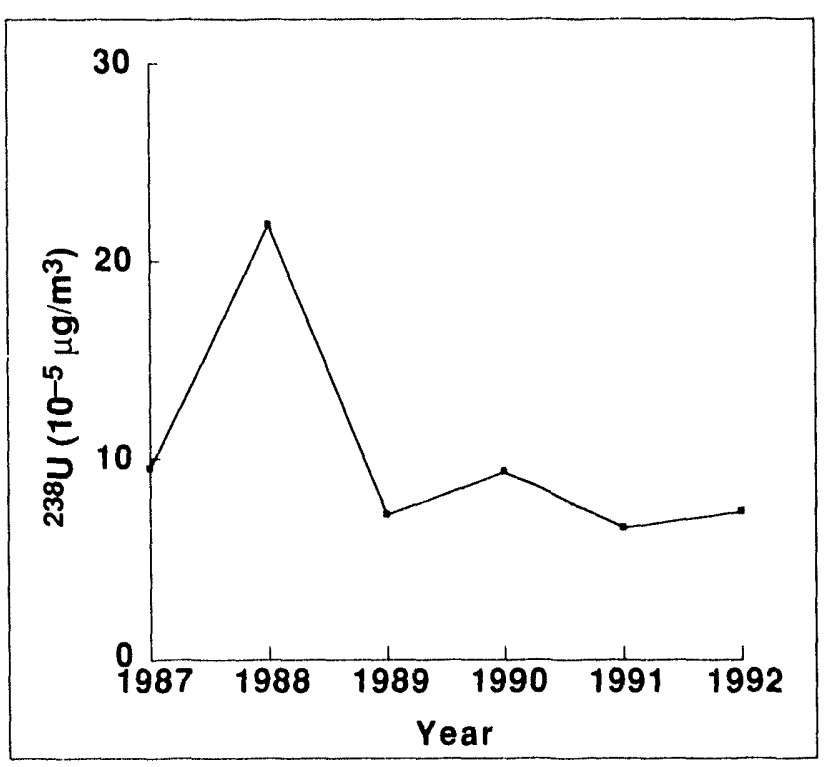

Figure 4-8. Hightest ammual arerage luranimm concentration in air at the Lizermore site perimeter (1987-92). 


\section{Environmental Monitoring Program Information}

Table 4-9 shows the airborne tritium concentrations measured at locations throughout the Livermore Valley.

The highest annual average tritium-inair concentration observed off-site was $0.96 \times 10^{-7} \mathrm{~Bq} / \mathrm{mL}$.

Table 4-10 presents the airborne tritiumconcentrations measured at the $\mathrm{SNL} /$ California site perimeter. The highest annual average tritium concentration was $2.17 \times 10^{-7} \mathrm{~Bq} / \mathrm{mL}$. The DOE allowable limit for tritium in air (derived concentration guide) for protection of the public is $3.7 \times 10^{-3} \mathrm{~Bq} / \mathrm{mL}\left(10,000 \times 10^{-11} \mu \mathrm{Ci} / \mathrm{mL}\right)$. Figure 4-9 shows the highest annual average values for off-site and on-site tritium in air concentrations for the years 1987-92. The graph clearly shows a decrease in the average tritium in air concentrations over the past six years. This corresponds well with the decreased amount of tritium released in recent years (see Fig. 4-1).

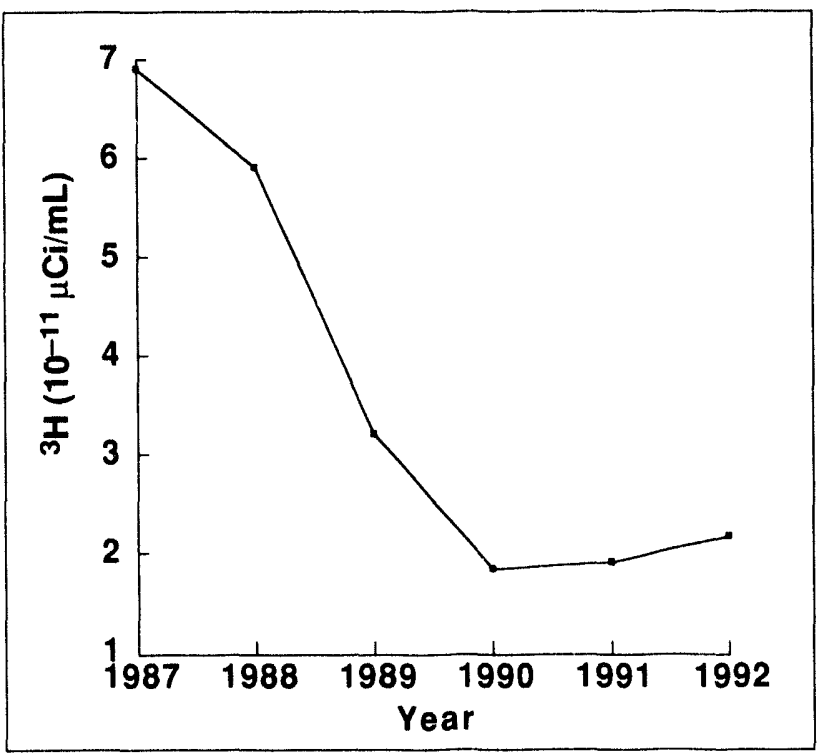

Figure 4-9. Highest annual average tritium concentration in air (1987-92).
The data discussed above represent only HTO. The three air samplers operated by SNL/California can discriminate between HTO and HT. Tritium was not detected above its limit of detection in 1992; therefore, data from these samplers is not included here. Additional air monitoring data may be found in the LLNL Site Environmental Report for 1992.27

\section{Water Sampling}

Although there are no direct hydrologic connections between the SNL/California site and local surface bodies of water (except the Arroyo Seco), the potential still exists for local surface water bodies to become contaminated due to exchange with pollutants in airborne effluents from site operations or rainout from effluent plumes. The effluent of primary concern from SNL/California operations in this respect is tritium, due to its gaseous nature, and a corresponding high potential for dispersion.

\section{Description}

All major bodies of water in the vicinity of SNL/California are sampled and analyzed for tritium. In addition, rainwater is collected and analyzed for tritium. Drinking water from the various companies serving the Livermore Valley are also sampled. Monitoring wells in the vicinity of the LWRP are also sampled in order to track any contamination resulting from the LWRP's past practice of discharging the treated effluent to the Arroyo.

\section{Locations}

Figure 4-10 shows the location of the surface water bodies in the vicinity of 


\section{Environmental Monitoring Program Information}

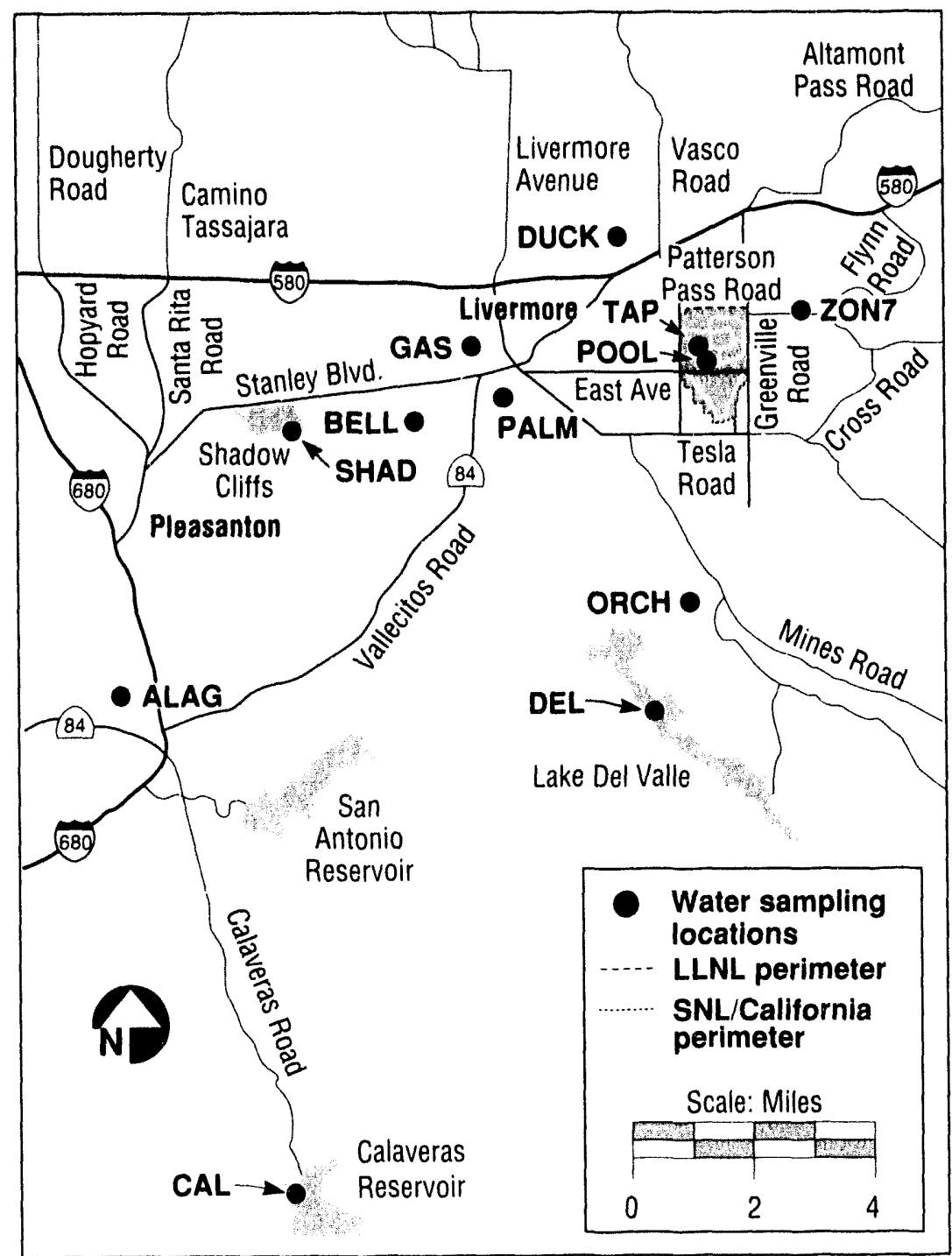

Figure 4-10. Surface water sampling locations, Livermore Valley.

SNL/California that are sampled. Location ZON7 is the reservoir of the Patterson Pass water treatment facility $(1.2 \mathrm{~km}$ east of LLNL), location DUCK is the Springtown pond (an artificial decorative pond $2.6 \mathrm{~km}$ northwest of LLNL), location DEL is Lake Del Valle (a water storage reservoir $8 \mathrm{~km}$ south of LLNL), location SHAD is the Shadow Cliffs Regional Park Recreation
Area (a reservoir produced by gravel excavation operations, $11 \mathrm{~km}$ west of LLNL), location CAL is the Calaveras Reservoir (25 km southwest of LLNL). The locations BELL, GAS, and PALM are tap water sources that receive water from different water services. Figure 4-11 shows the rainwater sampling locations. Annual samples are also collected from monitoring wells in 


\section{Environmental Monitoring Program Information}

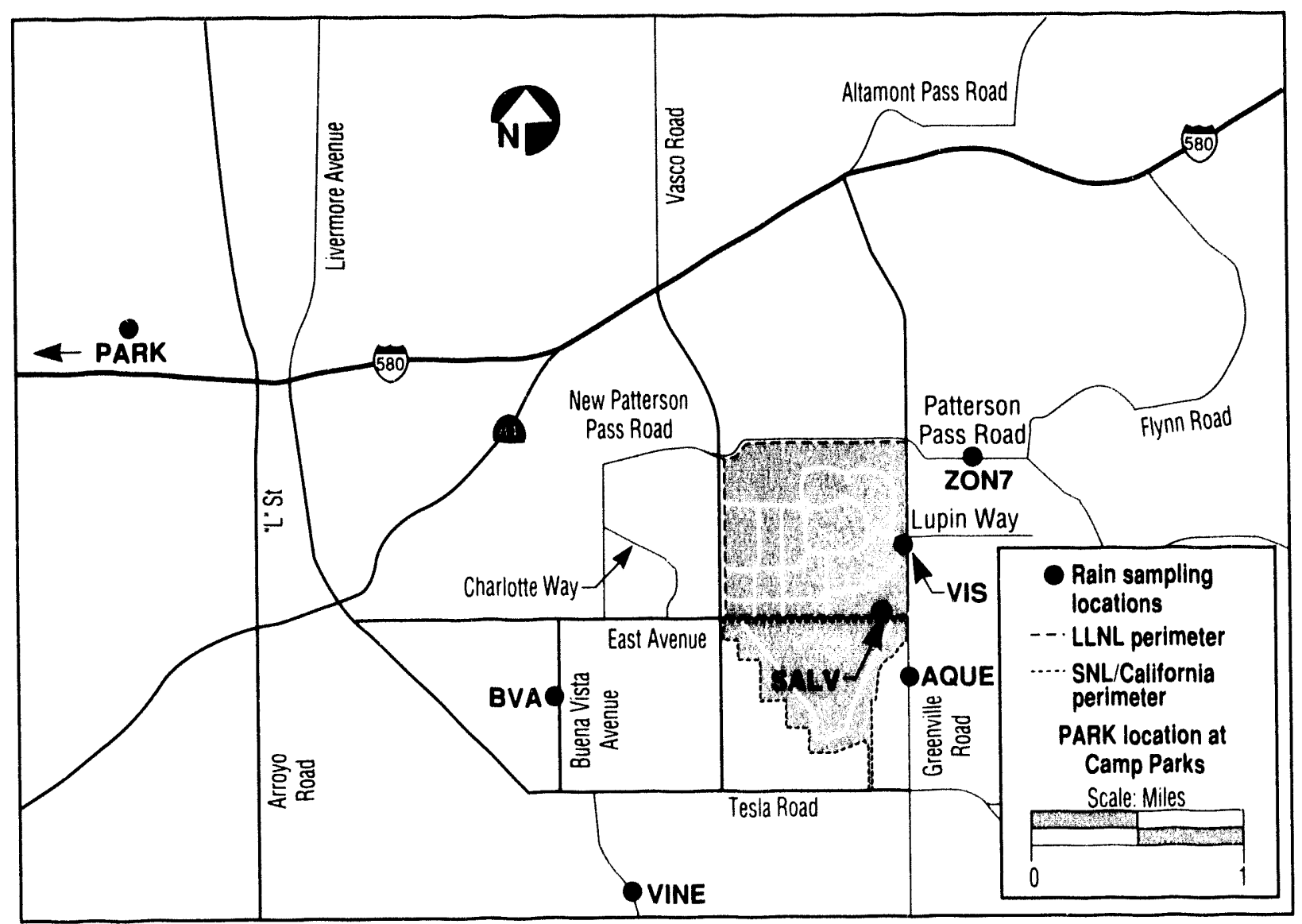

Figure 4-11. Rainzuater sampling locations, Livermore site and Valley.

the vicinity of the LWRP (see Fig. 4-12) in order to track low-level tritium concentrations due to the LWRP's past practice of discharging its effluent to the Arroyo Seco. The wells sampled monitor groundwater quality in the vicinity of the LWRP, and are not used as drinking water sources.

\section{Methods}

Surface-water samples are collected quarterly by grab sampling. Samples are collected in argon-flushed glass bottles for tritium analysis.

Rainwater samples are collected in rain gages or open stainless steel buckets during every rainstorm. They are then transferred to argon-flushed glass bottles before delivery to LLNL's Nuclear Chemistry Division.

\section{Quality Assurance}

Approximately $10 \%$ randomly chosen duplicates are collected for the surface water bodies. Random duplicates are also collected for rainwater samples if there is enough water for two samples. Laboratory blanks, consisting of dead water, are created and processed by LLNL's Nuclear Chemistry Laboratory. The DOE Environmental Monitoring Laboratory (EML) and the EPA Environmental Measurements and 


\section{Environmental Monitoring Program Information}

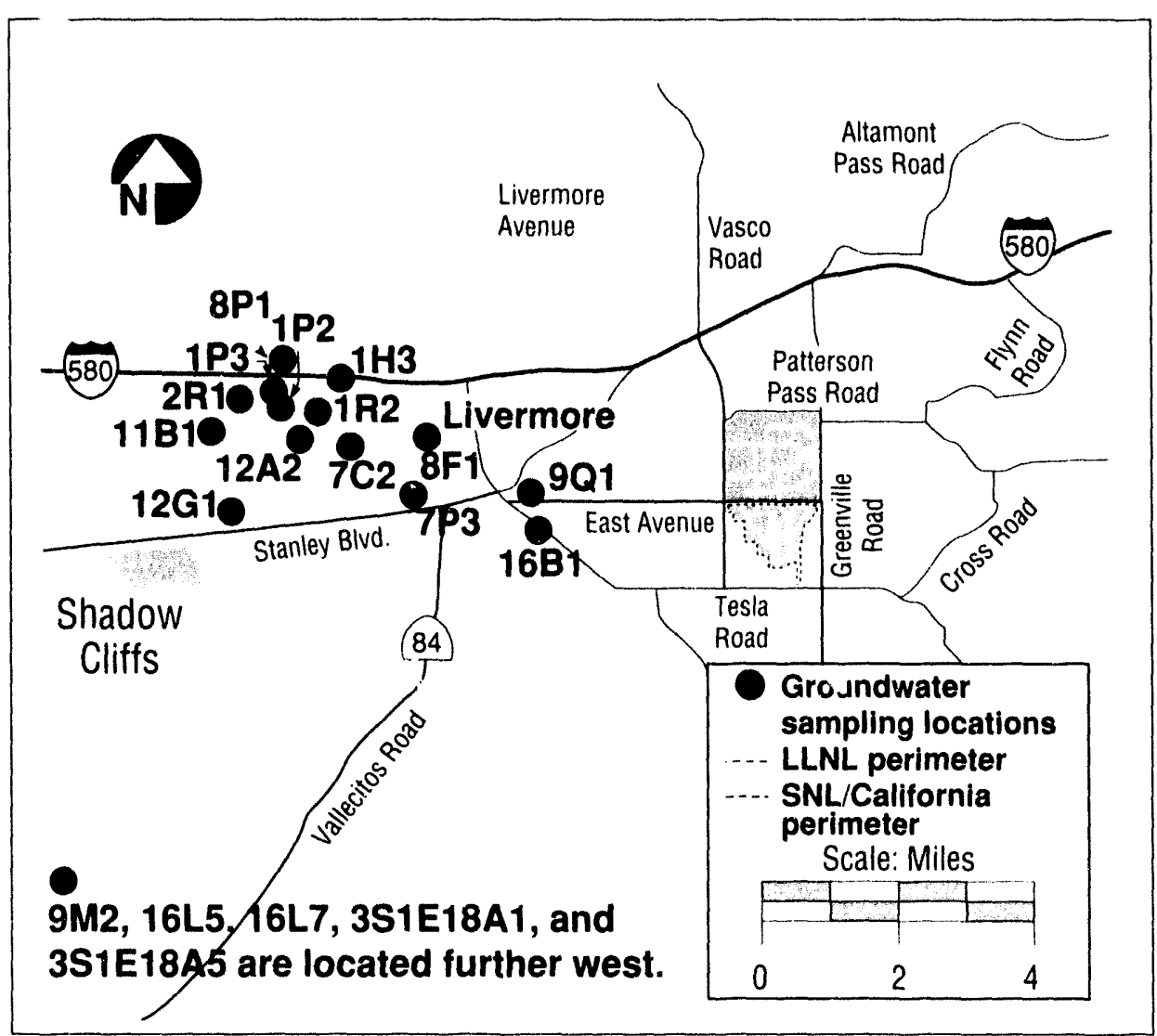

Figure 4-12. Groundzinter sampling locations, Lizermore' Valley.

Standards Laboratory (EMSL) both provide interlaboratory intercomparison samples for tritium in water. LLNL's Nuclear Chemistry Laboratory analyzes these samples twice per year (total of four samples). The analysis of spiked pseudosamples for these media is planned but has not yet been implemented.

\section{Results}

Table 4-11 presents the tritium concentrations measured in Livermore Valley surface waters. The highest measured value was at the Shadow Cliffs Regional Park Recreation Area at $3.51 \mathrm{~Bq} / \mathrm{L}$; higher concentrations were observed at the site, but are not considered part of the SNL/California monitor- ing network. This level represents only $0.5 \%$ of the DHS DWS for tritium. All surface water samples collected in 1992 were below DOE and California DHS permissible drinking water standards.

Table 4-12 presents the tritium concentrations measured in rainfall. The highest value measured off-site was $20.77 \mathrm{~Bq} / \mathrm{L}$ at the LLNL salvage yard. This value represents $2.8 \%$ of the DHS DWS for tritium. Figure 4-13 shows the highest annual average tritium in rainfall concentrations for 1987-92. The years 1990 and 1991 had higher concentrations than the earlier years, but levels dropped in 1992.

Table 4-13 presents the gross alpha and beta concentrations measured in water. All 


\section{Environmental Monitoring Program Information}

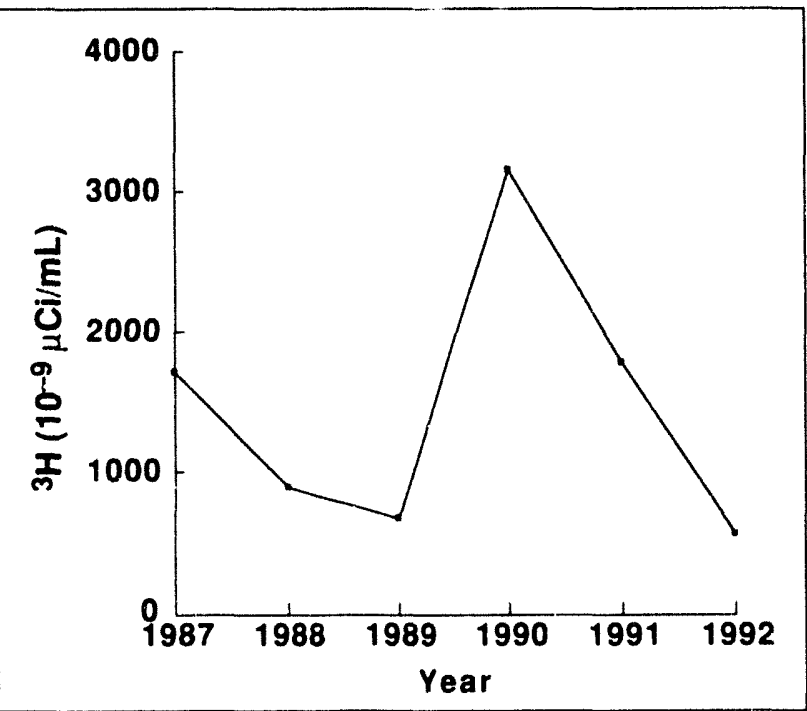

Figure 4-13. Highest annual average tritium concentration in rainfall (1987-92).

measurements in 1992 were below EPA and California DHS MCLs.

Table 4-14 presents the tritium concentrations in monitoring wells near the LWRP. Since the LWRP discontinued discharging to the Arroyo Seco several years ago, the tritium concentrations have been dropping.

\section{Storm Water Runoff}

Storm water may collect various radionuclides and hazardous constituents through contact with buildings, parking lots, and potentially contaminated soils. The storm water can then transport the pollutants into local drinking water supplies through recharge of the groundwater in the channel of the Arroyo Seco.

\section{Description}

Pollutants on paved surfaces or in the soil have the potential of exiting the site by becoming entrained or dissolved in storm- water runoff. Although the storm water from the Arroyo Seco is not used as a drinking water source, the arroyo is a source of groundwater recharge. To assess the contribution of SNL/California operations to pollutant loading in storm water, the surface runoff is collected at the discharge point from the SNL/California site (if water is available at this location).

\section{Locations}

Figure 4-14 shows the sampling locations for storm-water runoff and the Arroyo sediment sampling locations. Location ASS is intended to monitor the quality of the storm-water runoff from the Sandia site. No samples could be taken from location ASE due to lack of runoff.

\section{Methods}

Samples are collected during the period of actıve flow during the first storm of the year that produces enough runoff, and from a subsequent storm later in the year. The water is analyzed for selected metals, tritium, gross alpha, gross beta, pesticides, priority pollutants, and general water quality parameters. All samples are collected in accordance with available EPA guidance on sample collection and preservation.

\section{Quality Assurance}

A duplicate sample is collected from one of the storm-water locations (not necessarily one of the two SNL/California locations) during each storm that is sampled. A blank sample is also collected to assess the potential for contamination of the samples. 


\section{Environmental Monitoring Program Information}

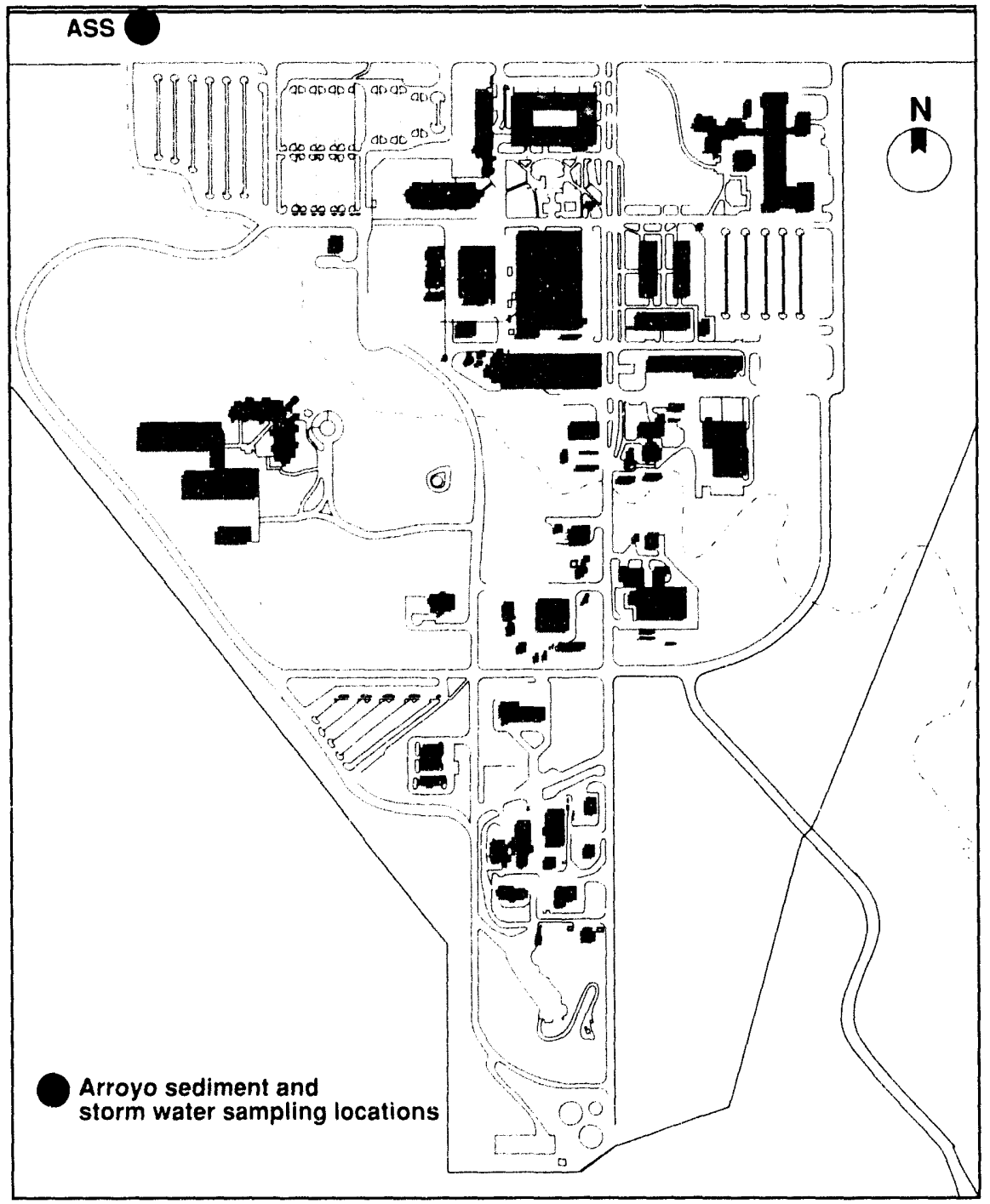

Figure 4-14. Storm-zoater

simpling locations.

\section{Results}

Table 4-15 presents the tritium, gross alpha, and gross beta concentrations measured in storm-water runoff in 1992. The highest measured tritium concentration was $61.79 \mathrm{~Bq} / \mathrm{L}$ ( $8 \%$ of the DHS DWS). It should be noted that this is not a source for drinking water.

Table 4-16 presents the data for the metals, organics, and pesticide analyses. No discharge standards for storm-water runoff have been established. The monitoring data are used to denote trends and optimize SNL/California's storm-water pollution prevention activities.

SNL/California is developing a new storm-water runoff monitoring program to meet the requirements of California's General Industrial Activities Storm Water NPDES permit. This permit requires Sandia to eliminate all non-storm-water discharges to the storm sewer system, prepare and 


\section{Environmental Monitoring Program Information}

implement a Storm-water Pollution Prevention Plan, and develop and conduct a Storm-water Monitoring Program. The monitoring program will begin in the 1993-94 rainy season.

\section{Soil/Sediment}

Soil provides an integrating medium that can account for contaminants released to the atmosphere. Sedimentary material from the arroyos is also an integrating medium for pollutants transported by storm-water runoff.

\section{Description}

Soil samples are collected from locations near the perimeter of the SNL/California site, and from more distant locations. It is assumed that any impacts due to site operations will be evident by greater concentrations in the near-field samples. Arroyo sediments are collected downstream of the site to assess any additions to the pollutant loading by site operations.

\section{Locations}

Figure 4-15 shows the nine surface soil sampling locations. The locations VIS and

Figure 4-15. Soil sampling locations.

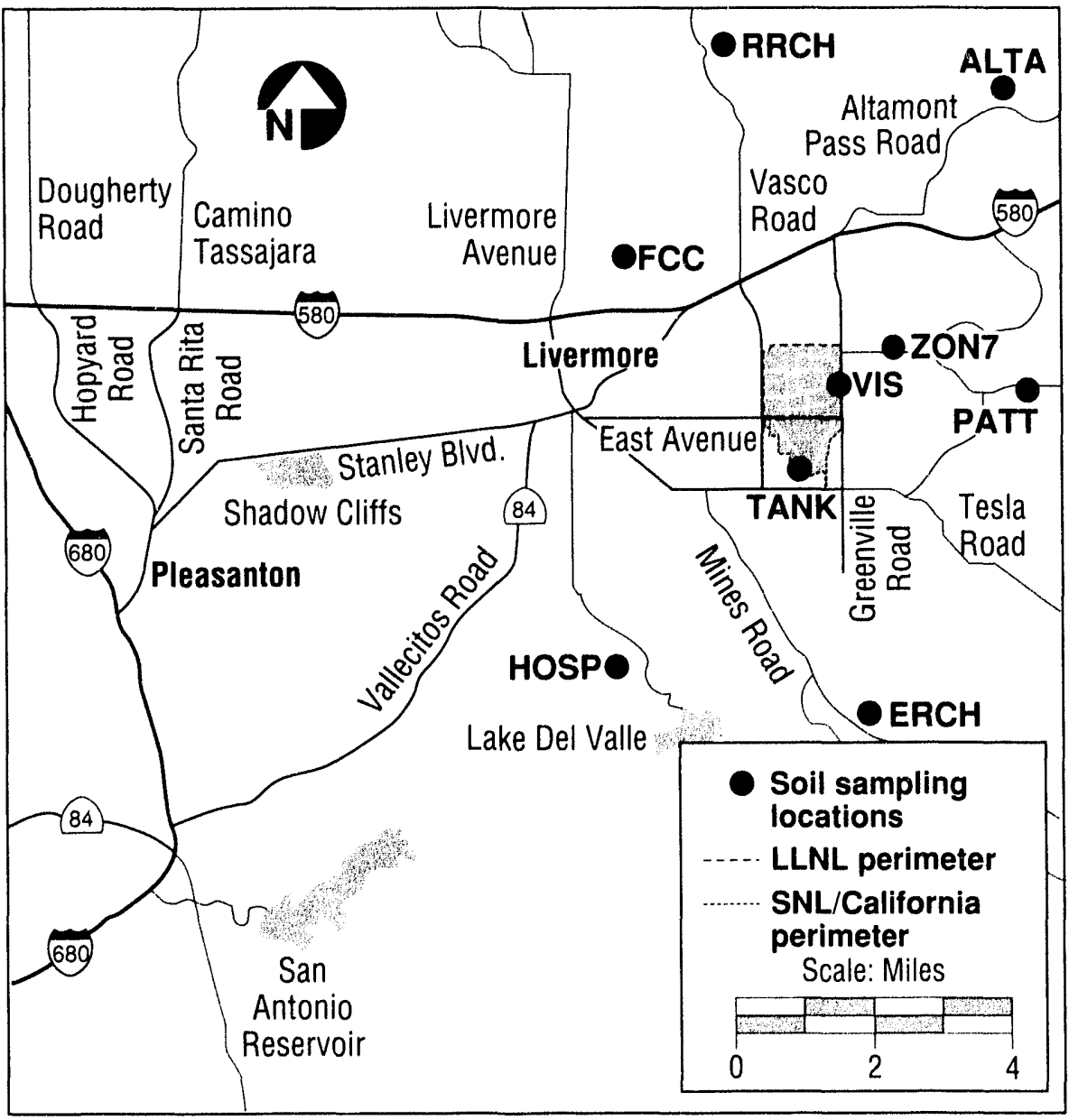




\section{Environmental Monitoring Program Information}

TANK may be considered near-field sampling locations. The remainder are distant locations. Figure 4-13 shows the arroyo sediment near-field sampling locations, ASS and ASE. If air samplers are present, the surface soil samples are taken as close as possible to these locations. Soil samples are taken from areas not shaded by trees or brush or areas that indicate evidence of human activity, such as construction or agriculture.

\section{Methods}

The annual soil samples are collected by taking cores approximately $10 \mathrm{~cm}$ in diameter and $5 \mathrm{~cm}$ deep. Five cores are collected from a $1 \mathrm{~m}^{2}$ area and are composited to make a total sample of approximately $1 \mathrm{~kg}$. The soil is then delivered to the Nuclear Chemistry Laboratory at LLNL, where it is ground and blended. Aliquots are then taken for gamma spectroscopy and plutonium analysis. The data of concern to $\mathrm{SNL} /$ California is the $238 \mathrm{U}$ concentration, which is determined by gamma spectroscopy.

Arroyo sediments are collected by using a split spoon sampler to take cores to a depth of $60 \mathrm{~cm}$. A portion of this core is then delivered to LLNL's Nuclear Chemistry Division for tritium and plutonium analyses. (SNL/California does not use plutonium; therefore, plutonium analyses are not included in this report.) The remainder of the core is sent to an off-site laboratory for analysis for metals, pesticides, PCBs, and priority pollutants. Sediments for tritium are transferred immediately after collection to glass jars, which are then kept in an ice chest until delivery to the Nuclear Chemistry Laboratory, where they are frozen until analyzed. The samples for volatile organics are sealed in the stainless steel sampling tubes with teflon sheets and tape, then kept in an ice chest until they are delivered to a commercial laboratory for analysis.

\section{Quality Assurance}

Duplicate soil and sediment samples are taken at $10 \%$ of the soil sampling sites, chosen at random. These locations are chosen from all of the locations sampled by LLNL, and thus may not include duplicates taken from a location near SNL/California.

DOE-EML interlaboratory comparison soils are analyzed twice a year for uranium by LLNL's Nuclear Chemistry Division. Reagent-grade sand is analyzed as blank samples (control) by the Nuclear Chemistry Division.

\section{Results}

Table 4-17 contains the data for the uranium in soils and arroyo sediments, and tritium in arroyo sediments. Levels of uranium and tritium in perimeter samples are similar to those found in off-site samples, indicating no adverse impact due to SNL/California operations.

Table 4-18 contains the data for metals in the arroyo sediments, and Table 4-19 contains the data for organic pollutants and pesticides in the arroyo sediments. No metals were detected at levels that would indicate pollution from the SNL/California site. Fuel hydrocarbons were detected at levels to be expecteci near any industrial site.

\section{Vegetation and Foodstuff}

Agricultural products have the potential to accumulate radionuclides and provide a transport pathway for human ingestion. Vegetation may become tainted with pollutants by direct deposition from the air onto 


\section{Environmental Monitoring Program Information}

the plants, or by uptake through the roots. The public may also be exposed to pollutants through drinking the milk of goats that graze on contaminated vegetation or through the consumption of meat from animals fed on contaminated vegetation. Another pathway for exposure of the public is through honey produced by bees feeding on contaminated vegetation.

\section{Description}

The only agricultural products produced in appreciable quantities in the vicinity of the SNL/California are wine, goat milk, honey, and beef. Wine is sampled rather than grapes in order to assess the dose to the public at the time of consumption. Wines from nearby vineyards and those in other parts of California and Europe are sampled in order to assess the impact of site operations. Grasses and weeds are sampled due to the lack of production in the area of significant quantities of grains or vegetables. Goat milk from distant areas is collected and compared to that produced locally. Honey from local hives is analyzed and compared to that from distant hives outside the Livermore Valley.

\section{Locations}

Figure 4-16 shows the sampling locations for vegetation. Vegetation samples AQUE, ZON7, VASW, and TESW are near-field

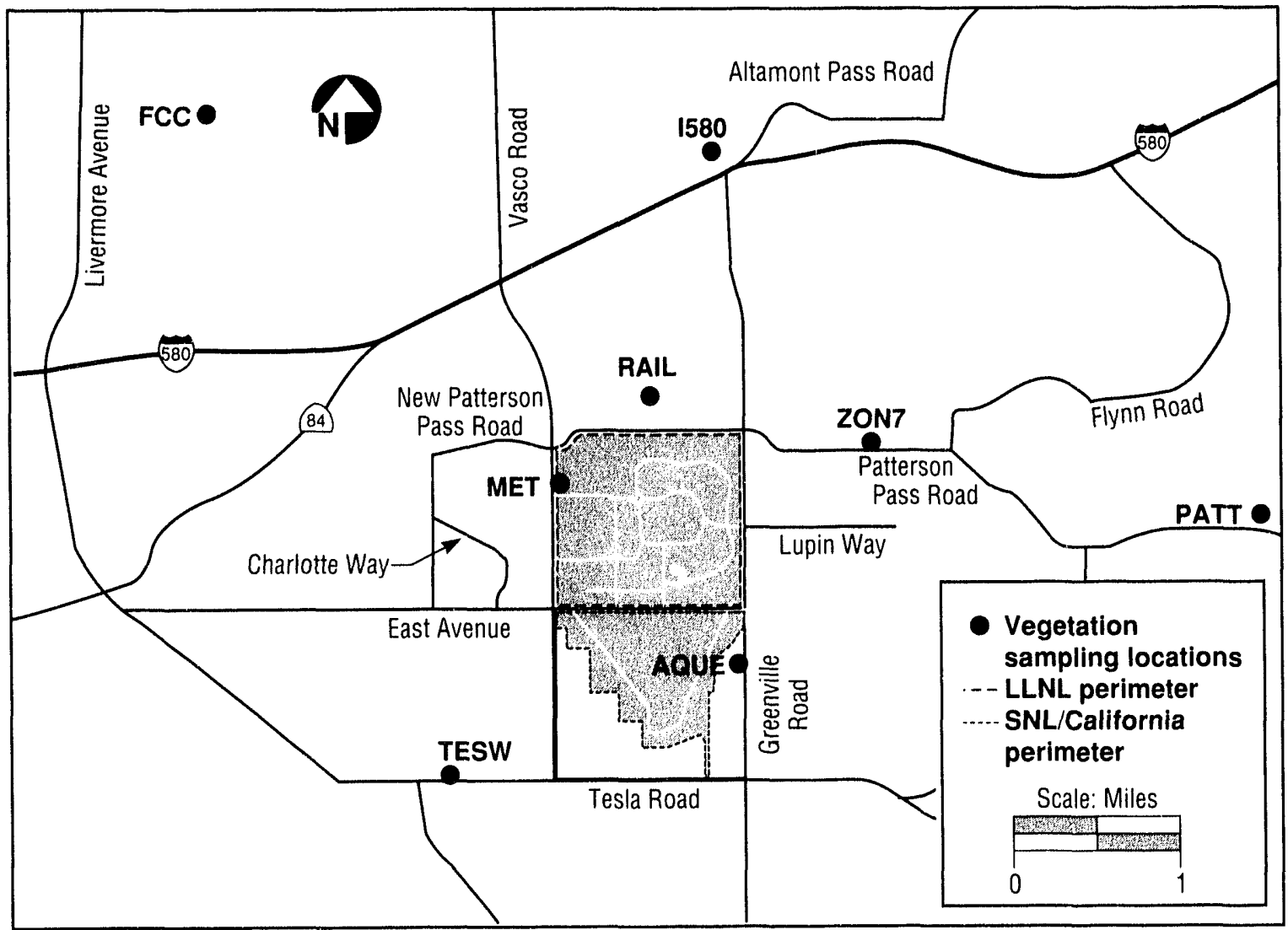

Figure 4-16. Vegetation sampling locations. 


\section{Environmental Monitoring Program Information}

locations. Locations FCC and PATT are distant locations. Milk locations WRD, MZF, LUP, and COOL are near-field locations. Locations MOD and TUR are distant locations. Purchased goat milk (CART) is used as a background sample. All of the Livermore Valley honey and wine locations are considered near-field.

\section{Methods}

Vegetation samples consist of grasses or weeds that are green at the time of sampling. These are intended to represent forage for animals in the region. Vegetation samples are collected quarterly. They are put in plastic bags and kept in an ice chest until delivery to LLNL's Nuclear Chemistry Laboratory, where they are kept frozen until analyzed.

Wine, milk, and honey samples are collected from local producers. Milk is collected monthly. Samples are usually not available during the winter months because the goats do not produce milk at this time of year. Honey and wine samples are collected annually. The wine samples collected are the most recent vintage available for any particular variety; therefore, each years' collection represents a number of vintage years. These samples are all analyzed for tritium content.

Milk samples are collected in plastic milk cartons and kept refrigerated until analyzed. Wine and honey samples are stored in an argon atmosphere after the original sample containers have been opened.

\section{Quality Assurance}

Duplicate samples are collected for approximately $10 \%$ of the sampling locations, chosen at random. Because blanks for these samples would be virtually impossible to create in the laboratory, commercial milk and honey are collected from production areas outside the Livermore Valley to provide an estimate of background concentrations. Wine samples are collected from a number of other California wine producers, as well as several European producers for comparison. The only reference standard for these media that exists is the EPA-EMSL radionuclide in milk interlaboratory comparison. This sample is not yet being analyzed by LLNL's Nuclear Chemistry Laboratory, but EPA-EMSL has been requested to add it to the distribution list for this sample. The creation of spiked pseudosamples for these media is planned, but has not yet been implemented. Nuclear Chemistry is evaluating methods for producing spiked pseudosamples and blanks for these media.

\section{Results}

Table 4-20 contains the tritium data for vegetation collected in 1992. The tritium concentrations dropped to a level lower than that seen for the past six years, following an increase in 1991. This increase is shown in Fig. 4-17, which plots the highest annual average tritium concentration in vegetation.

Table 4-21 presents the data for retail wines purchased in 1992. The wines represent several vintage years, and thus are not intended to be representative of the tritium releases in 1992, but rather to provide an index of public exposure. The Livermore Valley and European wines analyzed showed an increase in tritium content, whereas other California wines showed a decrease. Because these wines represent several vintages, the change in tritium content may be a statistical fluctuation or may be due to the wines chosen for sampling. 


\section{Environmental Monitoring Program Information}

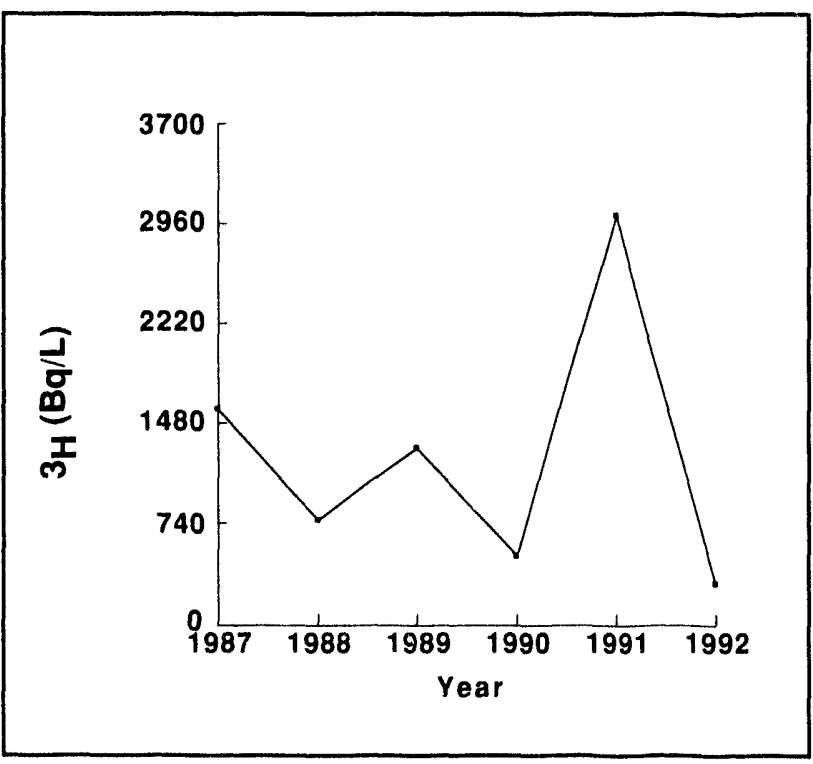

Figure 4-17. Highest annual average tritium concentration in vegetation (1987-92).

Table 4-22 presents the data for tritium concentrations in honey measured in 1992. The tritium concentrations measured in 1992 are generally higher than the 1991 values. Figure 4-18 shows the tritium concentrations in honey over the past six years. Livermore honeys are consistently slightly higher than other California honeys (except for in 1992), and also show a greater degree of variability in tritium content.

Table 4-23 presents the data for tritium concentrations in goat milk measured in 1992. The concentrations are lower than those measured in 1991 (except for the background samples). Figure 4-19 shows the highest annual average tritium concentrations in goat milk for 1987-92. The variability shown is not significant, as these concentrations are very near the method detection limit. Future sampling results will be monitored for trends.

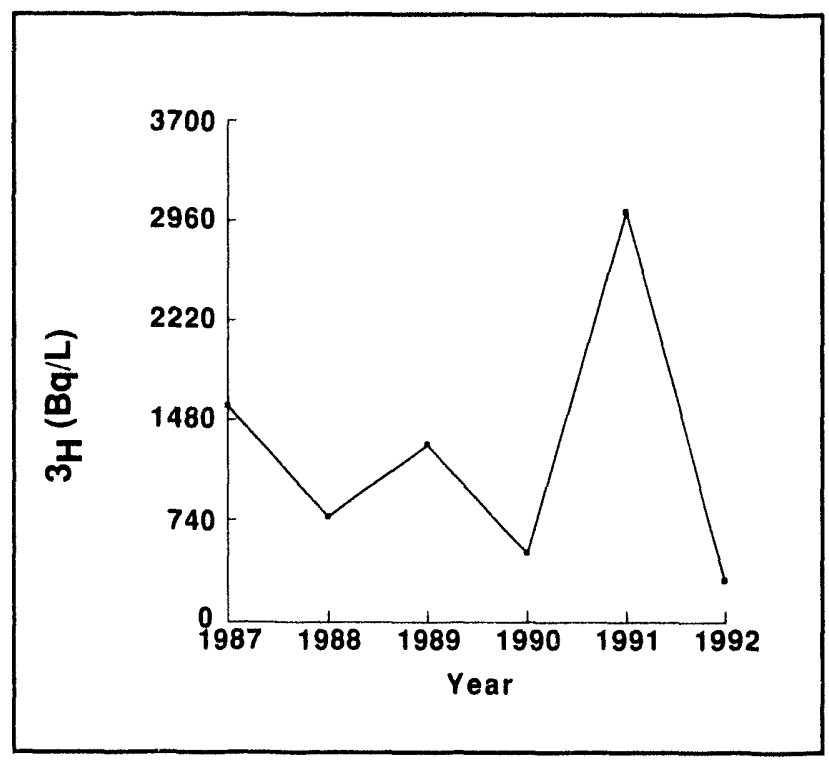

Figure 4-18. Highest annual average tritium concentration in honey (1987-92).

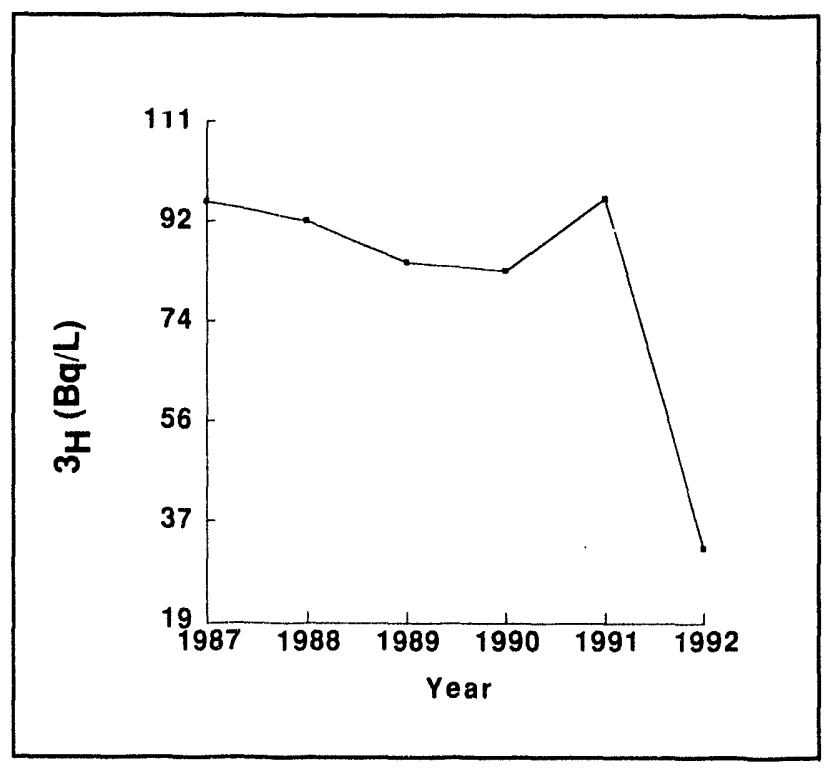

Figure 4-19. Highest annual average tritium concentration in goat milk (1987-92). 


\section{Environmental Monitoring Program Information}

\section{Summary}

The levels of tritium observed in foodstuffs produced in the Livermore Valley do not pose a health concern at any consumption rate. No specific safety standards exist for tritium in vegetation, wine, honey, or milk. However, the effective dose equivalent was calculated for vegetation and milk (the media for which consumption data are available). The highest dose calculated was $3.2 \times 10^{-3} \mathrm{mrem}, 0.003 \%$ of the DOE maximum permissible dose to a member of the public.

\section{External Radiation}

One of the pathways of exposure for population groups living in the vicinity of DOE facilities is external radiation. The only source of external radiation at the SNL/California site is large isotopic radiation sources used for industrial radiography purposes.

\section{Description}

Thermoluminescent dosimeters (TLDs) are used to measure the dose rates in the vicinity of SNL/California. Dosimeters are placed at the site perimeter and at more distant locations in the vicinity of the Livermore site. If site operations were contributing significantly to the external radiation dose, the dosimeters at the site perimeter would show a higher dose than those at more distant locations.

\section{Locations}

Figure 4-20 shows the locations for the fifteen TLDs at the SNL/California site perimeter (near-field). Figure 4-21 shows the 37 off-site (distant) TLD locations. In addition, SNL/California maintains four environmental TLDs on site. These locations are also shown in Fig. 4-20.

\section{Methods}

The site perimeter and off-site TLDs are collected quarterly by LLNL's Environmental Monitoring Group (EMG) and processed by LLNL's Hazards Control Department. The TLDs are contained in mylar bags while in the field. The sampling locations have been chosen (per USNRC Regulatory Guide $4.13)^{28}$ to avoid interferences from large objects in the vicinity. The TLDs used are Panasonic UD814 dosimeters. Each dosimeter contains three elements of thallium-activated calcium sulfate and one element of lithium borate. The four on-site dosimeters are collected by SNL/California Environmental Protection Department personnel and sent to SNL/New Mexico for analysis.

\section{Quality Assurance}

To be acceptable for placement in the field, all phosphors of the TLDs must be accurate to $\pm 5 \%$ upon calibration. Dosimeters with a known exposure are introduced as blind samples in the processing of the field dosimeters. These are equivalent to spiked pseudosamples for the purposes of establishing the accuracy of the system.

Duplicate dosimeter packets are placed at random locations and analyzed along with the routine dosimeters. The dosimeters are calibrated by using a source that is traceable to NIST. The California DHS also colocates TLDs at some of the monitoring stations to serve as an independent cross check. Exposures to the TLDs during collection and transit are determined by the use of unexposed TLDs (referred to as "transit controls"). These are taken on the collection 


\section{Environmental Monitoring Program Information}

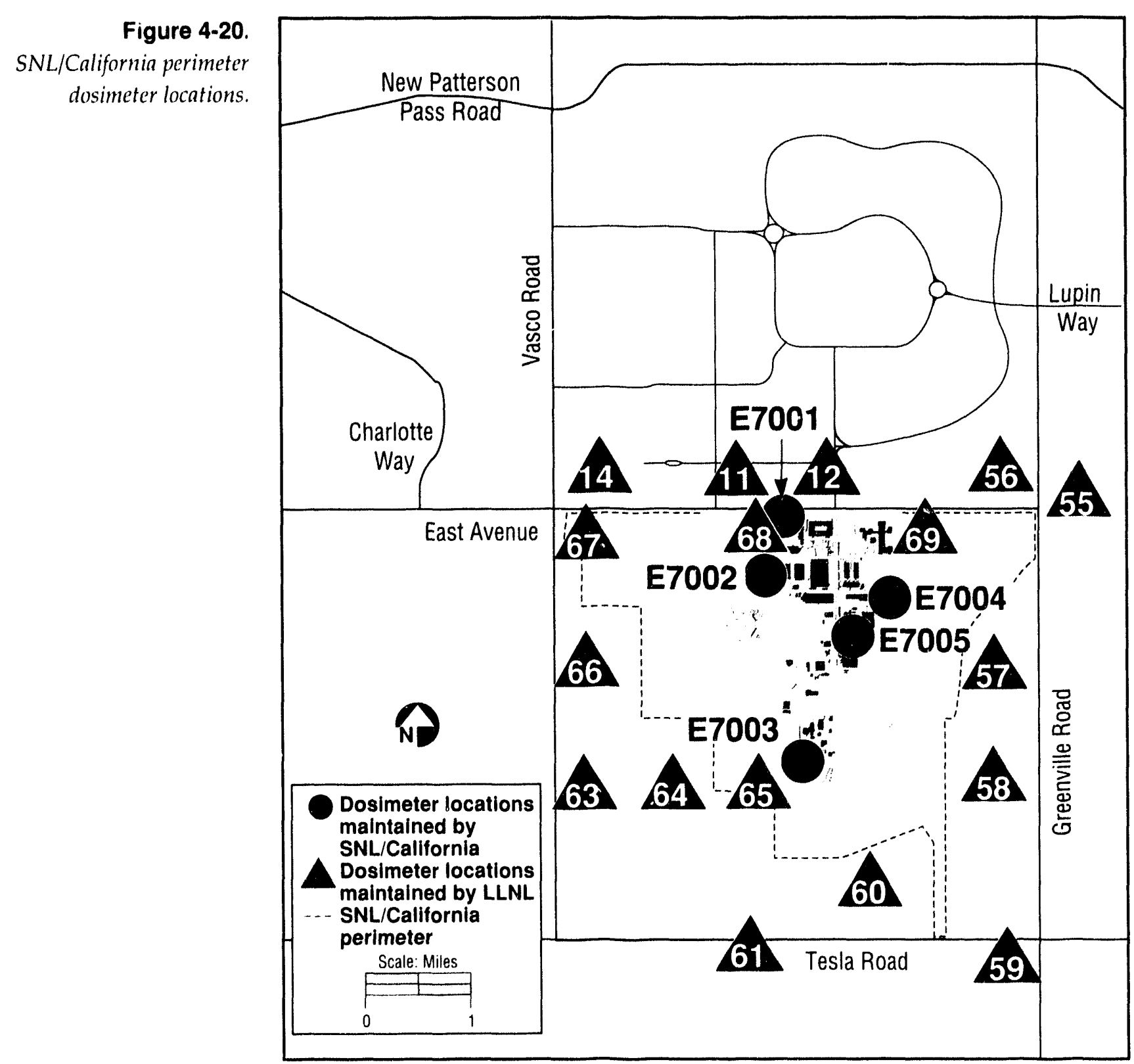

route, carried with field dosimeters during transit to the laboratory, and then read for accumulated dose.

\section{Results}

Table 4-24 presents the external radiation data for SNL/California site perimeter monitoring. The annual average external dose at the perimeter was $0.62 \mathrm{mSv}$ (62 mrem). Table 4-25 presents the external radiation monitoring data for Livermore Valley locations. A single dose of $0.95 \mathrm{mSv}$ was detected at location 36 during the fourth quarter. The TLD had been found on 


\section{Environmental Monitoring Program Information}

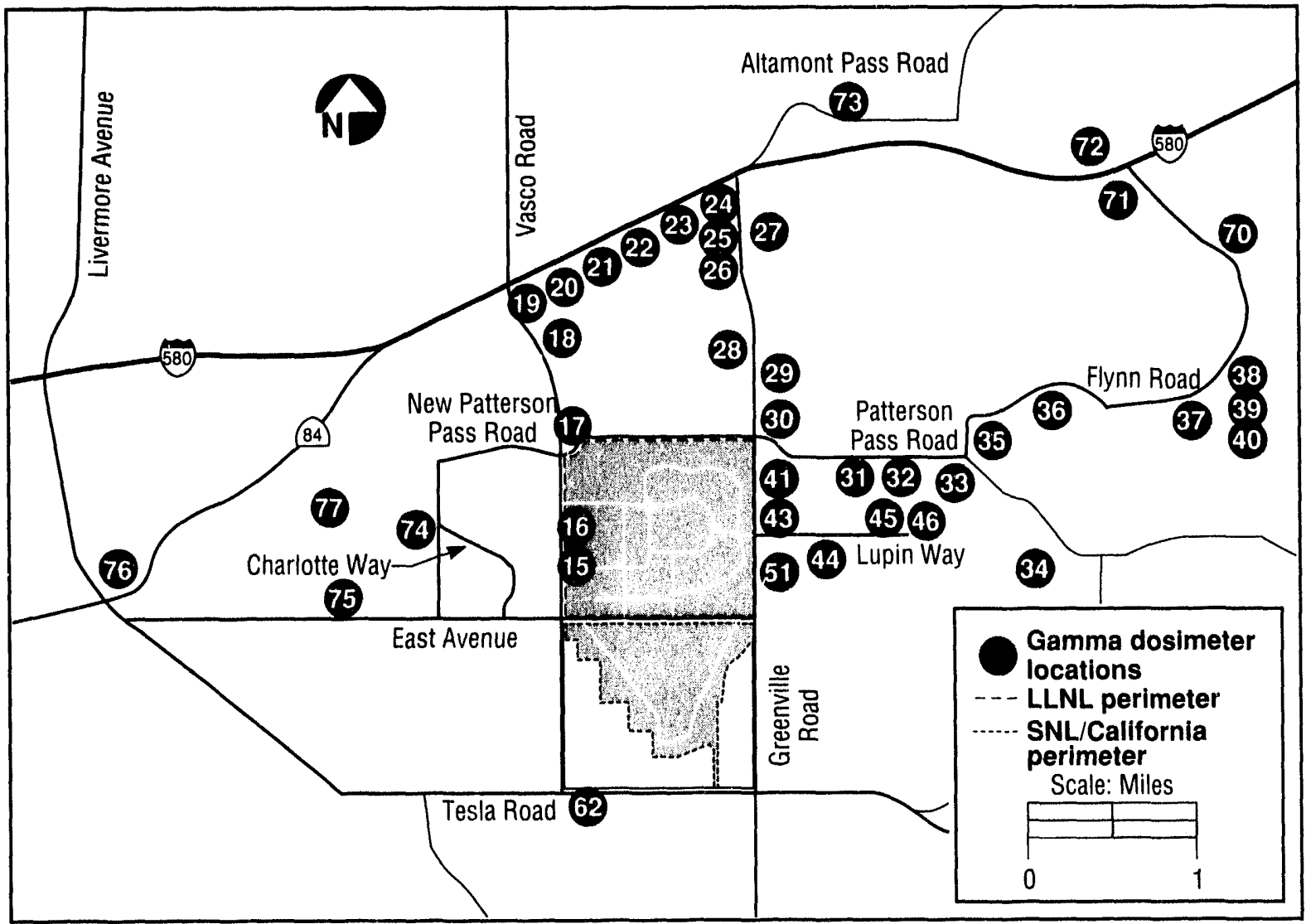

Figure 4-21. Off-site dosimeter locations.

the ground at the time of sample collection, which may have contributed to the higher measurement. The result is treated as an outlier in Table 4-24. The dose measured for the Livermore Valley locations was $0.66 \mathrm{mSv}$ (66 mrem) excluding the outlier and $0.68 \mathrm{mSv}$ including the outlier. If operations at SNL/California were producing excess external radiation, the perimeter (near-field) monitoring would show a higher dose than the more distant Livermore Valley monitoring. A student's t-test (a sta- tistical test) comparing the dose at the SNL/California site perimeter and the Livermore Valley showed the dose at the site perimeter to be significantly lower than the dose in the Livermore Valley. This result is probably due to differences in the local geology. 


\section{Environmental Monitoring Program Information}

\section{Table 4-1. Environmental Sampling Program Overview.}

\begin{tabular}{|c|c|c|c|c|c|}
\hline Medium & $\begin{array}{l}\text { No. of } \\
\text { Locations }\end{array}$ & Parameters & Frequency & $\begin{array}{l}\text { Requiring } \\
\text { Authority }\end{array}$ & $\begin{array}{l}\text { Authority } \\
\text { Reported to }\end{array}$ \\
\hline Air particulates & 17 & $\begin{array}{l}\text { gross alpha, gross beta, } \\
\text { uranium }\end{array}$ & weekly, monthly & DOE Order 5400.1 & DOE \\
\hline Air tritium & 17 & tritium & biweekly & DOE Order 5400.1 & DOE \\
\hline Soil & 15 & $\begin{array}{l}\text { uranium, tritium, metals, } \\
\text { solvents, pesticides }\end{array}$ & annually & DOE Order 5400.1 & DOE \\
\hline Groundwater & 22 & $\begin{array}{l}\text { gross alpha, gross beta, } \\
\text { tritium, metals, solvents, } \\
\text { pesticides }\end{array}$ & quarterly & $\begin{array}{l}\text { RWQCB Orders } \\
88-142 \text { and } \\
89-184\end{array}$ & RWQCB \\
\hline Surface water & 12 & $\begin{array}{l}\text { gross alpha, gross beta, } \\
\text { tritium }\end{array}$ & quarterly & DOE Order 5400.1 & DOE \\
\hline Sewer outfall & 1 & $\begin{array}{l}\text { tritium, metals, } \mathrm{pH}, \mathrm{TSS}, \\
\text { priority pollutants, } \\
\text { cyanide, BOD, COD, } \\
\text { TDS, oil and grease }\end{array}$ & $\begin{array}{l}\text { continuously, } \\
\text { weekly, semi- } \\
\text { annually }\end{array}$ & $\begin{array}{l}\text { DOE Order } 5400.1 \\
\text { City of Livermore }\end{array}$ & $\begin{array}{l}\text { DOE, City of } \\
\text { Livermore }\end{array}$ \\
\hline Stacks & 1 & tritium & $\begin{array}{l}\text { continuously, } \\
\text { weekly }\end{array}$ & $\begin{array}{l}\text { DOE Order } 5400.1 \\
\text { Clean Air Act } \\
\text { NESHAPS }\end{array}$ & DOE, EPA \\
\hline $\begin{array}{l}\text { Vegetation and } \\
\text { foodstuff }\end{array}$ & 43 & tritium & quarterly, monthly & DOE Order 5400.1 & DOE \\
\hline Storm water ${ }^{*}$ & 1 & $\begin{array}{l}\text { tritium, metals, solvents, } \\
\text { pesticides }\end{array}$ & $\begin{array}{l}\text { two storms per } \\
\text { year }\end{array}$ & $\begin{array}{l}\text { DOE Order } 5400.1 \text {, } \\
\text { Title } 40 \text { CFR, } 122\end{array}$ & DOE \\
\hline External radiation & 58 & radiation dose & quarterly & DOE Order 5400.1 & DOE \\
\hline
\end{tabular}

"The Storm-water Monitoring Program is being revised for the 1993-94 rainfail season.

Table 4-2. LECS Wastewater Analyses.

\begin{tabular}{ll}
\hline \multicolumn{1}{c}{ LECS } & \multicolumn{1}{c}{ Analyses } \\
\hline B. 913 & $\mathrm{pH}, \mathrm{As}, \mathrm{Cd}, \mathrm{Cr}, \mathrm{Cu}, \mathrm{Pb}, \mathrm{Hg}, \mathrm{Ni}, \mathrm{Ag}, \mathrm{Zn}$, \\
B. 910 & $\mathrm{pH}, \mathrm{As}, \mathrm{Cd}, \mathrm{Cr}, \mathrm{Cu}, \mathrm{Pb}, \mathrm{Hg}, \mathrm{Ni}, \mathrm{Ag}, \mathrm{Zn}$ \\
B. 968 & $\mathrm{pH},{ }^{3} \mathrm{H}$ \\
B. 961 & $\mathrm{pH}, \mathrm{As}, \mathrm{Cd}, \mathrm{Cr}, \mathrm{Cu}, \mathrm{Pb}, \mathrm{Hg}, \mathrm{Ni}, \mathrm{Ag}, \mathrm{Zn}$, \\
& ${ }^{3},{ }^{238} \mathrm{U}$ \\
B. 906 & $\mathrm{pH}, \mathrm{As}, \mathrm{Cd}, \mathrm{Cr}, \mathrm{Cu}, \mathrm{Pb}, \mathrm{Hg}, \mathrm{Ni}, \mathrm{Ag}, \mathrm{Zn}$ \\
B. $941^{\mathrm{a}}$ & $\mathrm{The}$ wastewater from this new facility wil \\
& be analyzed for process constituents \\
\hline
\end{tabular}

alntegrated Manufacturing Technologies Laboratory (IMTL),

which is expected to begin operation in 1993. 


\section{Environmental Monitoring Program Information}

Table 4-3. Semiannual Monitoring Data for the SNL/California Categorical Processes.

\begin{tabular}{|c|c|c|c|c|}
\hline \multirow{2}{*}{$\begin{array}{l}\text { Physical and Chemical } \\
\text { Parameters }(\mathrm{mg} / \mathrm{L})^{\mathrm{a}}\end{array}$} & \multicolumn{2}{|c|}{ Printed Wiring Lab } & \multicolumn{2}{|c|}{ Electroplating Lab } \\
\hline & Jan.-June & July-Dec. & Jan.-June & July-Dec. \\
\hline Biochemical oxygen demand & $<1.0$ & 5.6 & 15 & 86 \\
\hline $\mathrm{pH}$ (pH units) & 7.8 & 7.5 & 7.5 & 8.3 \\
\hline Total dissolved solids & 35 & $<10$ & 3900 & 13000 \\
\hline Total suspended solids & 9.0 & $<1.0$ & 6.0 & 42 \\
\hline Cyanide & $<0.02$ & $<0.01$ & $<0.02$ & $<0.01$ \\
\hline Arsenic & $<0.002$ & $<0.002$ & 0.011 & 0.024 \\
\hline Chromium & 1.4 & $<0.05$ & $<0.05$ & 1.1 \\
\hline Copper & 1.0 & $<0.05$ & 0.34 & 0.84 \\
\hline Lead & 0.062 & 0.0021 & 0.003 & 0.024 \\
\hline Nickel & $<0.1$ & $<0.1$ & $<0.1$ & 4.8 \\
\hline Zinc & 0.09 & $<0.05$ & 0.06 & 0.71 \\
\hline Oil and grease & $<5.0$ & 5.0 & $<5.0$ & $<5.0$ \\
\hline \multicolumn{5}{|l|}{ Organic compounds $(\mu g / L)^{b, c, d}$} \\
\hline Bis(2-ethylhexyl)phthalate & $<4.0$ & $<4.0$ & 21 & 14 \\
\hline Chloroform & $<1.0$ & 5.7 & $<1.0$ & $<1.0$ \\
\hline Methylene Chloride & 65 & 470 & $<5.0$ & $<5.0$ \\
\hline Nitrobenzene & $<4.0$ & $<4.0$ & $<4.0$ & 16 \\
\hline $1,1,1$, Trichloroethane & $<1.0$ & 37 & $<1.0$ & $<1.0$ \\
\hline $\begin{array}{l}\text { aMetals for which analysis was performed } \\
\text { um, mercury, and silver. However, all va } \\
\text { analyses were below detection limits. } \\
\text { bSamples also were analyzed for priority } \\
\text { to the following EPA methods: } 624 \text { (purge } \\
\text { (extractable pollutants), and } 608 \text { (organo } \\
\text { Data are reported in the Semiannual Cat } \\
\text { Report for SNL/California. }{ }^{26}\end{array}$ & $\begin{array}{l}\text { include cadmi- } \\
\text { or these metal } \\
\text { ants, according } \\
\text { pollutants), } 625 \\
\text { ne compounds). } \\
\text { cal Process }\end{array}$ & \multicolumn{3}{|c|}{$\begin{array}{l}\text { cAll priority pollutants were below applicable discharge limits. } \\
\text { dAcetone was also detected at } 24 \mu \mathrm{g} / \mathrm{L} \text { at the Electroplating } \\
\text { Laboratory (July-Dec.), but is not tabulated because it is not } \\
\text { currently a regulated substance. }\end{array}$} \\
\hline
\end{tabular}




\section{Environmental Monitoring Program Information}

Table 4-4. Weekly Metals Monitoring Data for the

Sandla Sanitary Sewer Outfall.a

\begin{tabular}{|c|c|c|c|c|c|c|c|c|c|}
\hline \multirow[b]{2}{*}{ Date } & As & $\mathrm{Cd}$ & $\mathrm{Cr}$ & $\mathrm{Cu}$ & $\mathbf{P b}$ & $\mathrm{Hg}$ & $\mathbf{N i}$ & $\mathbf{A g}$ & $Z n$ \\
\hline & \multicolumn{9}{|c|}{$(\mathrm{mg} / \mathrm{L})$} \\
\hline Jan. 06 & 0.006 & 50.05 & $\leq 0.05$ & 0.08 & 0.01 & $\leq 0.0002$ & $\leq 0.1$ & $\leq 0.05$ & 0.29 \\
\hline Jan. 13 & $\leq 0.002$ & $\leq 0.05$ & 0.09 & $\leq 0.05$ & 0.004 & $\leq 0.0002$ & $\leq 0.1$ & $\leq 0.05$ & 0.26 \\
\hline Jan. 20 & $\leq 0.002$ & $\leq 0.05$ & 0.08 & $\leq 0.05$ & 0.006 & $\leq 0.0002$ & $\leq 0.1$ & $\leq 0.05$ & 0.17 \\
\hline Jan. 27 & $\leq 0.002$ & $\leq 0.05$ & $\leq 0.05$ & 0.12 & 0.005 & $\leq 0.0002$ & $\leq 0.1$ & $\leq 0.05$ & 0.25 \\
\hline Feb. 03 & $\leq 0.002$ & $\leq 0.05$ & $\leq 0.05$ & 0.08 & 0.006 & $\leq 0.0002$ & $\leq 0.1$ & $\leq 0.05$ & 0.21 \\
\hline Feb. 10 & $\leq 0.002$ & $\leq 0.05$ & $\leq 0.05$ & 0.10 & 0.005 & $\leq 0.0002$ & $\leq 0.1$ & $\leq 0.05$ & 0.26 \\
\hline Feb. 17 & $\leq 0.002$ & $\leq 0.05$ & $\leq 0.05$ & 0.13 & 0.007 & $\leq 0.0002$ & $\leq 0.1$ & $\leq 0.05$ & 0.11 \\
\hline Feb. 24 & 0.014 & $\leq 0.05$ & $\leq 0.05$ & 0.14 & 0.009 & $\leq 0.0002$ & $\leq 0.1$ & $\leq 0.05$ & 0.25 \\
\hline Mar. 02 & 0.004 & $\leq 0.05$ & 0.02 & 0.14 & 0.003 & $\leq 0.0002$ & $\leq 0.1$ & $\leq 0.05$ & 0.24 \\
\hline Mar. 09 & $\leq 0.002$ & $\leq 0.05$ & $\leq 0.05$ & 0.12 & 0.004 & $\leq 0.0002$ & $\leq 0.1$ & 0.07 & 0.42 \\
\hline Mar. 16 & $\leq 0.002$ & $\leq 0.05$ & $\leq 0.05$ & 0.13 & 0.007 & 0.0004 & $\leq 0.1$ & $\leq 0.05$ & 0.28 \\
\hline Mar. 23 & $\leq 0.002$ & $\leq 0.05$ & 0.08 & 0.07 & 0.004 & $\leq 0.0002$ & $\leq 0.1$ & $\leq 0.05$ & 0.32 \\
\hline Mar. 30 & $\leq 0.002$ & $\leq 0.05$ & 0.08 & 0.08 & 0.006 & 0.0023 & $\leq 0.1$ & $\leq 0.05$ & 0.33 \\
\hline Apr. 06 & $\leq 0.002$ & $\leq 0.05$ & $\leq 0.05$ & $\leq 0.05$ & 0.003 & $\leq 0.0002$ & $\leq 0.1$ & $\leq 0.05$ & 0.18 \\
\hline Apr. 14 & $\leq 0.003$ & $\leq 0.05$ & 0.06 & $\leq 0.05$ & 0.003 & $\leq 0.0002$ & $\leq 0.1$ & $\leq 0.05$ & 0.15 \\
\hline Apr. 20 & $\leq 0.002$ & $\leq 0.05$ & $\leq 0.05$ & $\leq 0.05$ & 0.003 & $\leq 0.0002$ & $\leq 0.1$ & $\leq 0.05$ & 0.17 \\
\hline Apr. 27 & $\leq 0.002$ & $\leq 0.05$ & $\leq 0.05$ & 0.08 & 0.004 & $\leq 0.0002$ & $\leq 0.1$ & $\leq 0.05$ & 0.24 \\
\hline May 04 & $\leq 0.002$ & $\leq 0.05$ & $\leq 0.05$ & $\leq 0.05$ & 0.007 & 0.0003 & $\leq 0.1$ & $\leq 0.05$ & 0.21 \\
\hline May 11 & $\leq 0.002$ & $\leq 0.05$ & $\leq 0.05$ & 0.11 & 0.004 & $\leq 0.0002$ & $\leq 0.1$ & $\leq 0.05$ & 0.18 \\
\hline May 18 & 0.003 & $\leq 0.05$ & $\leq 0.05$ & 0.06 & 0.003 & $\leq 0.0002$ & $\leq 0.1$ & $\leq 0.05$ & 0.14 \\
\hline May 26 & $\leq 0.002$ & $\leq 0.05$ & $\leq 0.05$ & 0.11 & 0.011 & $\leq 0.0002$ & $\leq 0.1$ & $\leq 0.05$ & 0.29 \\
\hline June 01 & 0.004 & $\leq 0.05$ & $\leq 0.05$ & 0.13 & 0.005 & $\leq 0.0002$ & $\leq 0.1$ & $\leq 0.05$ & 0.32 \\
\hline June 08 & $\leq 0.002$ & $\leq 0.05$ & $\leq 0.08$ & 0.12 & 0.005 & $\leq 0.0002$ & $\leq 0.1$ & $\leq 0.05$ & 0.40 \\
\hline June 15 & $\leq 0.002$ & $\leq 0.05$ & $\leq 0.05$ & 0.11 & 0.005 & 0.0007 & $\leq 0.1$ & $\leq 0.05$ & 0.22 \\
\hline June 22 & 0.003 & $\leq 0.05$ & 0.11 & 0.12 & 0.004 & 0.0004 & $\leq 0.1$ & $\leq 0.05$ & 0.24 \\
\hline June 29 & 0.003 & $\leq 0.05$ & $\leq 0.05$ & 0.13 & 0.008 & $\leq 0.0002$ & $\leq 0.1$ & $\leq 0.05$ & 0.28 \\
\hline July 06 & $\leq 0.002$ & $\leq 0.05$ & $\leq 0.05$ & 0.08 & 0.004 & $\leq 0.0002$ & $\leq 0.1$ & $\leq 0.05$ & 0.21 \\
\hline July 13 & $\leq 0.002$ & $\leq 0.05$ & $\leq 0.05$ & 0.14 & 0.006 & $\leq 0.0004$ & $\leq 0.1$ & $\leq 0.05$ & 0.22 \\
\hline July 20 & $\leq 0.002$ & $\leq 0.05$ & 0.06 & 0.14 & 0.006 & $\leq 0.0002$ & $\leq 0.1$ & $\leq 0.05$ & 0.24 \\
\hline July 27 & $\leq 0.002$ & $\leq 0.05$ & $\leq 0.05$ & 0.05 & 0.004 & $\leq 0.0002$ & $\leq 0.1$ & $\leq 0.05$ & 0.16 \\
\hline
\end{tabular}




\section{Environmental Monitoring Program Information}

Table 4-4. Weekly Metals Monitoring Data for the Sandia Sanitary Sewer Outfall (concluded).

\begin{tabular}{lccccccccc}
\hline & As & Cd & Cr & Cu & Pb & Hg & Ni & Ag & Zn \\
\cline { 2 - 9 } Date & & & & & (mg/L) & & & & \\
\hline Aug. 03 & 0.003 & $\leq 0.05$ & $\leq 0.05$ & 0.10 & 0.006 & $\leq 0.0002$ & $\leq 0.1$ & $\leq 0.05$ & 0.28 \\
Aug. 10 & 0.008 & $\leq 0.05$ & $\leq 0.05$ & 0.13 & 0.007 & $\leq 0.0002$ & $\leq 0.1$ & $\leq 0.05$ & 0.34 \\
Aug. 17 & $\leq 0.002$ & $\leq 7.05$ & $\leq 0.05$ & 0.10 & 0.004 & 0.0005 & $\leq 0.1$ & 0.06 & 0.21 \\
Aug. 24 & $\leq 0.002$ & $\leq 0.15$ & $\leq 0.05$ & 0.09 & 0.005 & $\leq 0.0003$ & $\leq 0.1$ & $\leq 0.05$ & 0.22 \\
Aug. 31 & 0.003 & $\leq 0.05$ & $\leq 0.05$ & 0.15 & 0.005 & $\leq 0.0002$ & $\leq 0.1$ & $\leq 0.05$ & 0.23 \\
Sept. 08 & 0.003 & $\leq 0.05$ & $\leq 0.05$ & 0.08 & 0.005 & $\leq 0.0002$ & $\leq 0.1$ & $\leq 0.05$ & 0.44 \\
Sept. 14 & 0.004 & 0.01 & 0.07 & 0.11 & 0.007 & $\leq 0.0002$ & 0.005 & 0.014 & 0.20 \\
Sept. 21 & $\leq 0.002$ & $\leq 0.05$ & $\leq 0.05$ & 0.06 & 0.008 & $\leq 0.0002$ & $\leq 0.1$ & $\leq 0.05$ & 0.14 \\
Sept. 28 & 0.005 & 0.01 & 0.07 & 0.43 & 0.033 & 0.0012 & 0.015 & 0.06 & 1.3 \\
Oct. 05 & 0.002 & $\leq 0.05$ & $\leq 0.05$ & 0.12 & 0.009 & $\leq 0.0002$ & $\leq 0.1$ & 0.08 & 0.33 \\
Oct. 12 & 0.003 & $\leq 0.05$ & 0.06 & 0.06 & 0.009 & $\leq 0.0002$ & $\leq 0.1$ & $\leq 0.05$ & 0.3 \\
Oct. 19 & 0.006 & $\leq 0.05$ & 0.07 & 0.44 & 0.031 & 0.0019 & $\leq 0.1$ & $\leq 0.05$ & 1.1 \\
Oct. 26 & 0.005 & $\leq 0.05$ & $\leq 0.05$ & 0.16 & 0.016 & 0.0007 & $\leq 0.1$ & $\leq 0.05$ & 0.37 \\
Nov. 02 & 0.005 & $\leq 0.05$ & $\leq 0.05$ & 0.17 & 0.017 & 0.0012 & $\leq 0.1$ & $\leq 0.05$ & 0.43 \\
Nov. 09 & 0.005 & $\leq 0.05$ & $\leq 0.05$ & 0.36 & 0.028 & 0.0002 & $\leq 0.1$ & $\leq 0.05$ & 0.79 \\
Nov. 16 & 0.003 & $\leq 0.05$ & 0.06 & 0.17 & 0.017 & 0.0003 & $\leq 0.1$ & $\leq 0.05$ & 0.70 \\
Nov. 24 & 0.008 & $\leq 0.05$ & $\leq 0.05$ & 0.18 & 0.013 & 0.0005 & $\leq 0.1$ & $\leq 0.05$ & 0.37 \\
Nov. 30 & 0.002 & $\leq 0.05$ & $\leq 0.05$ & 0.19 & 0.009 & 0.0003 & $\leq 0.1$ & $\leq 0.05$ & 0.49 \\
Dec. 08 & 0.002 & $\leq 0.05$ & $\leq 0.05$ & 0.13 & 0.008 & 0.0004 & $\leq 0.1$ & $\leq 0.05$ & 0.32 \\
Dec. 14 & $\leq 0.002$ & $\leq 0.05$ & $\leq 0.05$ & 0.07 & 0.003 & $\leq 0.0002$ & $\leq 0.1$ & $\leq 0.05$ & 0.24 \\
Dec. 21 & 0.002 & $\leq 0.05$ & $\leq 0.05$ & 0.16 & 0.023 & 0.0004 & $\leq 0.1$ & $\leq 0.05$ & 0.31 \\
\hline Limit & $\mathbf{0 . 0 6}$ & $\mathbf{0 . 1 4}$ & $\mathbf{0 . 6 2}$ & $\mathbf{1 . 0}$ & $\mathbf{0 . 2}$ & $\mathbf{0 . 0 1}$ & $\mathbf{0 . 6 1}$ & $\mathbf{0 . 2}$ & $\mathbf{3 . 0}$ \\
\hline
\end{tabular}

asamples are collected as a weekly composite. 


\section{Environmental Monitoring Program Information}

Table 4-5. Weekly Physical Monitoring Data for the Sandia Sanitary Sewer Outfall.

\begin{tabular}{|c|c|c|c|c|c|c|c|c|}
\hline \multirow[b]{2}{*}{ Date } & $\mathrm{CN}^{\mathrm{a}}$ & BOD & $C O D^{b}$ & $O \& G^{a}$ & TDS $^{\mathbf{b}}$ & TSS $^{b}$ & $\mathrm{pH}^{\mathbf{b}}$ & $3 \mathrm{H}^{6}$ \\
\hline & \multicolumn{6}{|c|}{$(\mathrm{mg} / \mathrm{L})$} & \multicolumn{2}{|c|}{ (pH units) $\left(10^{-6} \mu \mathrm{Ci} / \mathrm{mL}\right)$} \\
\hline Jan. 06 & $\leq 0.02$ & 130 & 200 & 25 & 310 & 72 & 7.2 & 1.6 \\
\hline Jan. 13 & $\leq 0.02$ & 76 & 80 & 53 & 120 & 76 & 8.3 & 0.5 \\
\hline Jan. 20 & $\leq 0.02$ & 100 & 220 & 29 & 300 & 92 & 8.3 & 6.1 \\
\hline Jan. 27 & $\leq 0.02$ & 65 & 300 & 22 & 190 & 80 & 8.0 & 2.3 \\
\hline Feb. 03 & $\leq 0.02$ & 66 & 190 & 23 & 190 & 78 & 7.9 & 3.6 \\
\hline Feb. 10 & $\leq 0.02$ & 130 & 400 & 29 & 290 & 130 & 8.4 & 2.4 \\
\hline Feb. 17 & $\leq 0.02$ & 65 & 190 & 32 & 180 & 60 & 8.1 & 1.1 \\
\hline Feb. 24 & $\leq 0.02$ & 68 & 350 & 44 & 240 & 68 & 8.1 & 8.1 \\
\hline Mar. 02 & $\leq 0.02$ & 170 & 450 & 41 & 280 & 170 & 7.8 & $\leq 2.6$ \\
\hline Mar. 09 & $\leq 0.02$ & 94 & 480 & 34 & 310 & 120 & 8.6 & 0.5 \\
\hline Mar. 16 & $\leq 0.02$ & 150 & 520 & 26 & 250 & 140 & 8.0 & 0.0 \\
\hline Mar. 23 & $\leq 0.02$ & 68 & 230 & 43 & 280 & 52 & 8.0 & 1.2 \\
\hline Mar. 30 & $\leq 0.02$ & 270 & 470 & 30 & 260 & , & 7.6 & 14 \\
\hline Apr. 06 & $\leq 0.02$ & 100 & 480 & 31 & 460 & .0 & 8.0 & 0.1 \\
\hline Apr. 14 & $\leq 0.02$ & 169 & 400 & 31 & 250 & 120 & 7.9 & 0.78 \\
\hline Apr. 20 & $\leq 0.02$ & 90 & 330 & 25 & 180 & 60 & 7.4 & 6.6 \\
\hline Apr. 27 & $\leq 0.02$ & 140 & 430 & 41 & 270 & 110 & 7.7 & 2.0 \\
\hline May 04 & $\leq 0.02$ & 110 & 160 & 24 & 220 & 130 & 8.0 & 3.4 \\
\hline May 11 & $\leq 0.02$ & 68 & 220 & 20 & 310 & 76 & 7.4 & 2.1 \\
\hline May 18 & $\leq 0.02$ & 480 & 110 & 21 & 100 & 46 & 7.9 & 11 \\
\hline May 26 & $\leq 0.02$ & 75 & 240 & 38 & 140 & 95 & 7.4 & 11 \\
\hline June 01 & $\leq 0.02$ & 57 & 230 & 42 & 160 & 67 & 7.5 & 12 \\
\hline June 08 & $\leq 0.01$ & 64 & 300 & 32 & 190 & 110 & 7.6 & 11 \\
\hline June 15 & $\leq 0.01$ & 84 & 280 & 20 & 190 & 82 & 7.9 & 4.3 \\
\hline June 22 & $\leq 0.01$ & 49 & 300 & 11 & 210 & 92 & 7.7 & 6.1 \\
\hline June 29 & $\leq 0.01$ & 96 & 330 & 28 & 260 & 95 & 7.7 & 7.5 \\
\hline July 06 & $\leq 0.01$ & 78 & 270 & 24 & 140 & 80 & 7.9 & 1.9 \\
\hline July 13 & $\leq 0.01$ & 110 & 430 & 31 & 250 & 190 & 7.8 & 0.7 \\
\hline July 20 & $\leq 0.01$ & 71 & 220 & 16 & 160 & 84 & 7.5 & 2.2 \\
\hline July 27 & $\leq 0.01$ & 130 & 180 & 26 & 150 & 66 & 7.3 & 2.0 \\
\hline
\end{tabular}




\section{Environmental Monitoring Program Information}

Table 4-5. Weekly Physical Monitoring Data for the Sandia Sanitary Sewer Outfall (concluded).

\begin{tabular}{|c|c|c|c|c|c|c|c|c|}
\hline \multirow[b]{2}{*}{ Date } & $\mathrm{CN}^{\mathrm{a}}$ & BOD & $C^{b}$ & $O \& G^{a}$ & TDS $^{b}$ & TSS $^{b}$ & $\mathrm{pH}^{b}$ & $3 H^{b}$ \\
\hline & \multicolumn{6}{|c|}{$(\mathrm{mg} / \mathrm{L})$} & \multicolumn{2}{|c|}{ (pH units) $\left(10^{-6} \mu \mathrm{Ci} / \mathrm{mL}\right)$} \\
\hline Aug. 03 & $\leq 0.01$ & 180 & 320 & 42 & 210 & 150 & 7.3 & 0.0 \\
\hline Aug. 10 & $\leq 0.01$ & 83 & 330 & 26 & 200 & 84 & 7.7 & 6.4 \\
\hline Aug. 17 & $\leq 0.01$ & 74 & 120 & 19 & 130 & 82 & 7.6 & 1.5 \\
\hline Aug. 24 & $\leq 0.01$ & 100 & 250 & 55 & 160 & 98 & 7.3 & 0.0 \\
\hline Aug. 31 & $\leq 0.01$ & 77 & 280 & 19 & 190 & 88 & 7.5 & 2.7 \\
\hline Sept. 08 & $\leq 0.01$ & 100 & 330 & 22 & 200 & 100 & 7.3 & 2.5 \\
\hline Sept. 14 & $\leq 0.01$ & 79 & 260 & 11 & 170 & 74 & 7.6 & 3.5 \\
\hline Sept. 21 & $\leq 0.01$ & 120 & 260 & 30 & 240 & 74 & 7.4 & 4.2 \\
\hline Sept. 28 & $\leq 0.01$ & 200 & 630 & 50 & 270 & 1300 & 7.4 & 3.6 \\
\hline Oct. 05 & $\leq 0.01$ & 300 & 460 & 26 & 280 & 740 & 7.5 & 4.6 \\
\hline Oct. 12 & $\leq 0.01$ & 130 & 350 & 25 & 230 & 120 & 7.6 & 1.9 \\
\hline Oct. 19 & $\leq 0.01$ & 580 & 1000 & 23 & 310 & 190 & 7.6 & 3.6 \\
\hline Oct. 26 & $\leq 0.01$ & 450 & 440 & 69 & 240 & 180 & 7.4 & 3.0 \\
\hline Nov. 02 & $\leq 0.01$ & 260 & 470 & 31 & 240 & 500 & 7.1 & $\leq 2.6$ \\
\hline Nov. 09 & $\leq 0.01$ & 480 & 1000 & 73 & 250 & 270 & 7.4 & $\leq 2.6$ \\
\hline Nov. 16 & $\leq 0.01$ & 720 & 1400 & 19 & 210 & 770 & 8.3 & $\leq 2.6$ \\
\hline Nov. 24 & $\leq 0.01$ & 200 & 330 & 23 & 220 & 370 & 7.5 & $\leq 2.6$ \\
\hline Nov. 30 & $\leq 0.01$ & 640 & 920 & 26 & 200 & 460 & 7.8 & 0.56 \\
\hline Dec. 08 & $\leq 0.01$ & 160 & 380 & 25 & 140 & 160 & 8.2 & $\leq 2.6$ \\
\hline Dec. 14 & $\leq 0.01$ & 90 & 440 & 36 & 140 & 140 & 7.0 & $\leq 2.6$ \\
\hline Dec. 21 & $\leq 0.01$ & 180 & 1000 & 56 & 130 & 220 & 7.2 & $\leq 2.6$ \\
\hline Limit & 0.04 & 300 & - & 100 & $325^{c}$ & 300 & $6<\mathrm{pH}<9$ & $1 \times 10^{4}$ \\
\hline
\end{tabular}

a Grab sample.

bWeekly composite sample.

cThe discharge limit for total dissolved solids (TDS) is an incremental limit, i.e., $325 \mathrm{mg} / \mathrm{L}$ above the concentration of the incoming water. 
Environmental Monitoring Program Information

Table 4-6. Monthly Priority Pollutant Monitoring Data for the Sandia

Sanitary Sewer Outfall. ${ }^{a}$

\begin{tabular}{|c|c|c|c|c|c|c|c|c|c|c|c|c|}
\hline \multirow[b]{2}{*}{ Parameter } & Jan & Feb & Mar & Apr & May & Jun & Jul & Aug & Sep & Oct & Nov & Dec \\
\hline & \multicolumn{12}{|c|}{$\mu \mathrm{mg} / \mathrm{L}$} \\
\hline 2-Chlorophenol & 4.0 & $<40$ & $<40$ & $<4.0$ & $<4.0$ & $<4.0$ & $<20$ & $<40$ & $<40$ & 4.0 & $<40$ & $<40$ \\
\hline 4-Methylphenolc & 69 & $<40$ & 80 & 42 & 21 & 42 & 55 & $<40$ & 90 & $<4.0$ & 90 & $<40$ \\
\hline $\begin{array}{l}\text { 1,4-Dichloroben - } \\
\text { zene }\end{array}$ & 3.0 & $<30$ & $<30$ & $<3.0$ & $<3.0$ & $<3.0$ & $<20$ & $<30$ & $<30$ & 3.0 & $<30$ & $<30$ \\
\hline Acenaphthene & 6.0 & $<50$ & $<50$ & $<5.0$ & $<5.0$ & $<5.0$ & $<30$ & $<50$ & $<50$ & $<5.0$ & $<50$ & $<50$ \\
\hline Acetone $e^{c}$ & 22 & 16 & 630 & $<10$ & $<10$ & $<10$ & $<10$ & $<10$ & 22 & $<10$ & 28 & $<10$ \\
\hline Benzoic acidc & 1200 & $<100$ & 1700 & 140 & 82 & 140 & 130 & 500 & 1100 & 26 & 1200 & $<100$ \\
\hline $\begin{array}{l}\text { Bis (2-ethylhexyl) } \\
\text { phthalate }\end{array}$ & $<4.0$ & $<40$ & $<40$ & $<4.0$ & 13 & $<4.0$ & $<20$ & $<100$ & $<100$ & $<10$ & $<100$ & $<100$ \\
\hline Chloroform ${ }^{d}$ & 11 & 19 & 15 & 8.0 & 8.0 & 8.0 & 8.0 & 17 & 21 & 19 & 15 & 10 \\
\hline Freon $113^{c}$ & $<1.0$ & $<1.0$ & $<1.0$ & $<1.0$ & $<1.0$ & $<1.0$ & $<1.0$ & $<1.0$ & $<1.0$ & 2.0 & $<1.0$ & $<2.0$ \\
\hline Methoxychlor & $<0.2$ & 0.1 & $<0.2$ & $<2.0$ & $<0.4$ & $<2.0$ & $<0.2$ & $<0.2$ & $<0.2$ & $<0.2$ & $<0.2$ & $<0.2$ \\
\hline Phenol & 60 & $<50$ & 60 & 70 & 19 & 70 & 47 & $<50$ & 70 & 6.0 & 60 & $<50$ \\
\hline Pyrene & 9 & $<20$ & $<20$ & $<2.0$ & $<2.0$ & $<2.0$ & $<10$ & $<20$ & $<20$ & 2.0 & $<20$ & $<20$ \\
\hline Toluene & 2.0 & 1.0 & 1.0 & 3.0 & 4.0 & 3.0 & $<1.0$ & $<1.0$ & $<1.0$ & $<1.0$ & 14 & $<1.0$ \\
\hline
\end{tabular}

apositively detected parameters only. All other parameters were below the detection limit.

bThe discharge limit for total toxic organics is $1000 \mu \mathrm{g} / \mathrm{L}$.

cThese constituents are not listed as EPA priority pollutants and are

not included in the definition of total toxic organics. There are no specific discharge limits for these parameters.

dChloroform is a common constituent of chlorinated water.

Table 4-7. Wind Direction vs. Wind Speed.

Wind Speed $(\mathrm{m} / \mathrm{s})$

\begin{tabular}{lcccccc}
\cline { 2 - 6 } \multicolumn{1}{c}{ Direction } & $\begin{array}{c}\mathbf{0 . 0 - 0 . 9} \\
\text { (Calm) }\end{array}$ & $\mathbf{1 . 0 - 2 . 9}$ & $\mathbf{3 . 0 - 4 . 9}$ & $\mathbf{5 . 0 - 6 . 9}$ & $\mathbf{2 7 . 0}$ & Total \\
\hline N & 1.1 & 0.6 & 0.3 & 0.3 & 0.0 & 2.3 \\
NNE & 1.1 & 1.6 & 1.1 & 0.3 & 0.0 & 4.1 \\
NE & 1.1 & 2.2 & 2.1 & 0.2 & 0.0 & 5.6 \\
ENE & 1.1 & 1.8 & 0.3 & 0.0 & 0.0 & 3.2 \\
E & 1.1 & 2.9 & 0.1 & 0.0 & 0.0 & 4.1 \\
ESE & 1.1 & 4.7 & 0.4 & 0.0 & 0.0 & 6.2 \\
SE & 1.1 & 4.1 & 0.5 & 0.2 & 0.0 & 5.9 \\
SSE & 1.1 & 2.1 & 0.5 & 0.1 & 0.0 & 3.8 \\
S & 1.1 & 2.8 & 0.9 & 0.3 & 0.1 & 5.2 \\
SSW & 1.1 & 3.0 & 1.4 & 0.4 & 0.3 & 6.2 \\
SW & 1.1 & 5.6 & 5.0 & 3.2 & 1.0 & 15.9 \\
WSW & 1.1 & 7.1 & 6.5 & 2.7 & 0.4 & 17.8 \\
W & 1.1 & 4.6 & 3.6 & 2.2 & 0.2 & 11.7 \\
WNW & 1.1 & 1.8 & 0.6 & 0.5 & 0.1 & 4.1 \\
NW & 1.1 & 1.0 & 0.1 & 0.0 & 0.0 & 2.2 \\
NNW & 1.1 & 1.0 & 0.2 & 0.1 & 0.0 & 2.4 \\
\hline Total & 17.6 & $\mathbf{4 6 . 9}$ & $\mathbf{2 3 . 6}$ & $\mathbf{1 0 . 5}$ & $\mathbf{2 . 1}$ & $\mathbf{1 0 0 . 7}$ \\
\hline
\end{tabular}

4-32 SNL/CA Site Environmental Report for 1992 


\section{Environmental Monitoring Program Information}

Table 4-8. Uranium Concentrations in Air, Measured at the Site Perimeter.

\begin{tabular}{|c|c|c|c|c|c|c|c|}
\hline Month & Location $^{a}$ & $\begin{array}{c}{ }^{238} \mathrm{U} \\
{\left[10^{-5} \mu \mathrm{g} / \mathrm{m}^{3}\right]}\end{array}$ & $\begin{array}{c}{ }^{235} U /^{238} U \\
{\left[10^{-3}\right]}\end{array}$ & Month & Locationa & $\frac{{ }^{238} \mathrm{U}}{\left[10^{-5} \mu \mathrm{g} / \mathrm{m}^{3}\right]}$ & $\begin{array}{c}{ }^{235} U /^{238} U \\
{\left[10^{-3}\right]}\end{array}$ \\
\hline \multirow[t]{2}{*}{ Jan. } & SALV & 2.06 & 7.28 & July & SALV & 8.35 & 7.35 \\
\hline & CAFE & 5.08 & 7.04 & & CAFE & 9.11 & 7.49 \\
\hline \multirow[t]{2}{*}{ Feb. } & SALV & 2.37 & 7.09 & Aug. & SALV & 11.90 & 7.23 \\
\hline & CAFE & 5.46 & 7.21 & & CAFE & 14.20 & 7.20 \\
\hline \multirow[t]{2}{*}{ Mar. } & SALV & 2.74 & 7.00 & Sept. & SALV & 18.30 & 7.29 \\
\hline & CAFE & 6.66 & 7.02 & & CAFE & 16.00 & 7.33 \\
\hline \multirow[t]{2}{*}{ Apr. } & SALV & 2.41 & $5.72^{b}$ & Oct. & SALV & 7.89 & 7.18 \\
\hline & CAFE & 3.90 & $9.28^{\mathrm{b}}$ & & CAFE & 10.90 & 7.24 \\
\hline \multirow[t]{2}{*}{ May } & SALV & 11.40 & 7.11 & Nov. & SALV & 7.13 & 7.17 \\
\hline & CAFE & 9.89 & 7.18 & & CAFE & 7.07 & 7.28 \\
\hline \multirow[t]{2}{*}{ June } & SALV & 10.50 & 7.21 & Dec. & SALV & 2.24 & 7.16 \\
\hline & CAFE & 8.56 & 7.13 & & CAFE & 4.23 & 7.31 \\
\hline
\end{tabular}

\begin{tabular}{lccc} 
& \multicolumn{3}{c}{ Annual Mean ${ }^{238} \mathrm{U}$ Concentrations } \\
\cline { 2 - 4 } Location & $10^{-5} \mu \mathrm{g} / \mathrm{m}^{3}$ & SDM $(\%)^{\mathrm{c}}$ & $\%$ of DCG \\
\hline SALV & 7.27 & 5.16 & 0.02 \\
CAFE & 8.42 & 3.84 & 0.03 \\
\hline
\end{tabular}

\begin{tabular}{lll} 
& \multicolumn{2}{c}{ Annual Mean ${ }^{235} \mathbf{U} /{ }^{238} \mathbf{U}$ Ratio } \\
\cline { 2 - 3 } Location & $\mathbf{1 0}^{\mathbf{- 3}} \mu \mathbf{g} / \mathbf{m}^{\mathbf{3}}$ & SDM $(\%)$ \\
\hline SALV & $7.19(7.07)^{e}$ & $0.10(0.43)^{e}$ \\
CAFE & $7.22(7.39)^{\ominus}$ & $0.13(0.61)^{e}$ \\
\hline
\end{tabular}

aSee Fig. 4-6 for sampling locations.

bOutlier.

cStandard deviation of the mean.

$\mathrm{dDCG}=0.3 \mu \mathrm{g} / \mathrm{m}^{3}$ for $238 \mathrm{U}$ activity in air. 


\section{Environmental Monitoring Program Information}

Table 4-9. Tritium Concentrations in Air, Measured in the Livermore Valley.

\begin{tabular}{|c|c|c|c|c|c|}
\hline \multirow[b]{2}{*}{ Month } & \multicolumn{5}{|c|}{ Sampling Location ${ }^{a}$} \\
\hline & XRDS & ZON7 & $\begin{array}{c}\text { ALTA } \\
\mathrm{Bq} / \mathrm{mL} \pm 2 \sigma\end{array}$ & LCCY & FIRE \\
\hline \multirow[t]{2}{*}{ Jan. } & $0.81 \pm 0.14$ & $0.67 \pm 0.12$ & $0.25 \pm 0.12$ & $0.37 \pm 0.10$ & $0.67 \pm 0.12$ \\
\hline & $1.62 \pm 0.15$ & $1.17 \pm 0.13$ & $0.38 \pm 0.11$ & $0.14 \pm 0.09$ & $0.58 \pm 0.10$ \\
\hline \multirow[t]{2}{*}{ Feb. } & $1.45 \pm 0.22$ & $1.26 \pm 0.16$ & $0.42 \pm 0.18$ & $1.12 \pm 0.25$ & $0.95 \pm 0.15$ \\
\hline & $0.79 \pm 0.19$ & $1.16 \pm 0.13$ & $0.44 \pm 0.14$ & $1.11 \pm 0.23$ & $0.77 \pm 0.15$ \\
\hline \multirow[t]{2}{*}{ Mar. } & $1.31 \pm 0.21$ & $1.36 \pm 0.19$ & $0.51 \pm 0.17$ & $0.72 \pm 0.18$ & $0.97 \pm 0.18$ \\
\hline & $0.73 \pm 0.18$ & $0.91 \pm 0.16$ & $0.68 \pm 0.17$ & $0.81 \pm 0.18$ & $0.57 \pm 0.15$ \\
\hline \multirow[t]{2}{*}{ Apr. } & $0.50 \pm 0.16$ & $0.93 \pm 0.15$ & $0.67 \pm 0.15$ & $0.15 \pm 0.13$ & $0.20 \pm 0.12$ \\
\hline & $0.45 \pm 0.18$ & $0.68 \pm 0.15$ & $0.51 \pm 0.17$ & $0.19 \pm 0.18$ & $0.22 \pm 0.14$ \\
\hline \multirow[t]{2}{*}{ May } & $0.87 \pm 0.15$ & $0.98 \pm 0.14$ & $0.67 \pm 0.15$ & $0.28 \pm 0.17$ & $0.45 \pm 0.15$ \\
\hline & $0.34 \pm 0.14$ & $0.68 \pm 0.13$ & $0.33 \pm 0.13$ & $\leq 0.30$ & $\leq 0.26$ \\
\hline \multirow[t]{2}{*}{ June } & $0.63 \pm 0.13$ & $1.23 \pm 0.12$ & $0.25 \pm 0.09$ & $\leq 1.54$ & $0.24 \pm 0.13$ \\
\hline & $0.47 \pm 0.15$ & $0.88 \pm 0.16$ & $0.28 \pm 0.15$ & $\leq 0.30$ & $0.21 \pm 0.13$ \\
\hline \multirow[t]{3}{*}{ July } & $0.61 \pm 0.20$ & $1.07 \pm 0.20$ & $0.39 \pm 0.12$ & $0.23 \pm 0.16$ & $\leq 0.34$ \\
\hline & $0.60 \pm 0.18$ & $1.08 \pm 0.19$ & $0.48 \pm 0.18$ & $\leq 0.30$ & $0.27 \pm 0.17$ \\
\hline & $0.37 \pm 0.17$ & $1.24 \pm 0.21$ & $\leq 0.38$ & $\leq 0.36$ & $\leq 0.32$ \\
\hline \multirow[t]{2}{*}{ Aug. } & $0.51 \pm 0.17$ & $1.18 \pm 0.20$ & $\leq 0.34$ & $\leq 0.36$ & $0.27 \pm 0.15$ \\
\hline & $1.05 \pm 0.16$ & $1.40 \pm 0.17$ & $0.61 \pm 0.15$ & $0.26 \pm 0.17$ & $0.59 \pm 0.15$ \\
\hline \multirow[t]{2}{*}{ Sept. } & $0.32 \pm 0.08$ & $0.82 \pm 0.10$ & $0.26 \pm 0.11$ & $0.38 \pm 0.29$ & $0.31 \pm 0.08$ \\
\hline & $0.58 \pm 0.12$ & $1.02 \pm 0.13$ & $0.39 \pm 0.19$ & $\leq 0.28$ & $0.19 \pm 0.11$ \\
\hline \multirow{2}{*}{ Oct. } & $0.36 \pm 0.14$ & $0.55 \pm 0.15$ & $0.64 \pm 0.20$ & $0.55 \pm 0.16$ & $0.93 \pm 0.16$ \\
\hline & $0.67 \pm 0.19$ & $1.02 \pm 0.21$ & $0.42 \pm 0.19$ & $0.60 \pm 0.17$ & $0.94 \pm 0.19$ \\
\hline \multirow[t]{2}{*}{ Nov. } & $0.71 \pm 0.24$ & $1.30 \pm 0.24$ & $0.62 \pm 0.30$ & $0.48 \pm 0.20$ & $0.87 \pm 0.23$ \\
\hline & $0.45 \pm 0.10$ & $0.65 \pm 0.11$ & $0.50 \pm 0.11$ & $1.01 \pm 0.12$ & $1.62 \pm 0.14$ \\
\hline \multirow[t]{3}{*}{ Dec. } & $0.27 \pm 0.10$ & $0.38 \pm 0.12$ & $-b$ & $0.39 \pm 0.12$ & 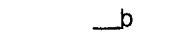 \\
\hline & $0.20 \pm 0.16$ & $0.67 \pm 0.14$ & $0.28 \pm 0.21$ & $0.15 \pm 0.12$ & $0.25 \pm 0.17$ \\
\hline & $0.50 \pm 0.16$ & $0.78 \pm 0.18$ & $0.24 \pm 0.16$ & $0.24 \pm 0.10$ & $0.53 \pm 0.13$ \\
\hline Meanc & 0.58 & 0.96 & 0.41 & 0.39 & 0.45 \\
\hline $\operatorname{SDM}(\%)$ & 39 & 28 & 68 & 49 & 46 \\
\hline $\begin{array}{l}\text { Percent of } \\
\text { DCG }^{d}\end{array}$ & $1.6 \times 10^{-3}$ & $2.6 \times 10^{-3}$ & $1.1 \times 10^{-3}$ & $1.0 \times 10^{-3}$ & $1.2 \times 10^{-3}$ \\
\hline
\end{tabular}

asee Fig. 4-7 for sampling locations.

bNo data.

cLivermore Valley overall average $=0.56 \times 10^{-7} \mathrm{~Bq} / \mathrm{mL}$.

$\mathrm{dDCG}=3.7 \times 10^{-3} \mathrm{~Bq} / \mathrm{mL}$. 


\section{Environmental Monitoring Program Information}

Table 4-10. Tritium Concentrations in Air, Measured at the Site Perimeter.

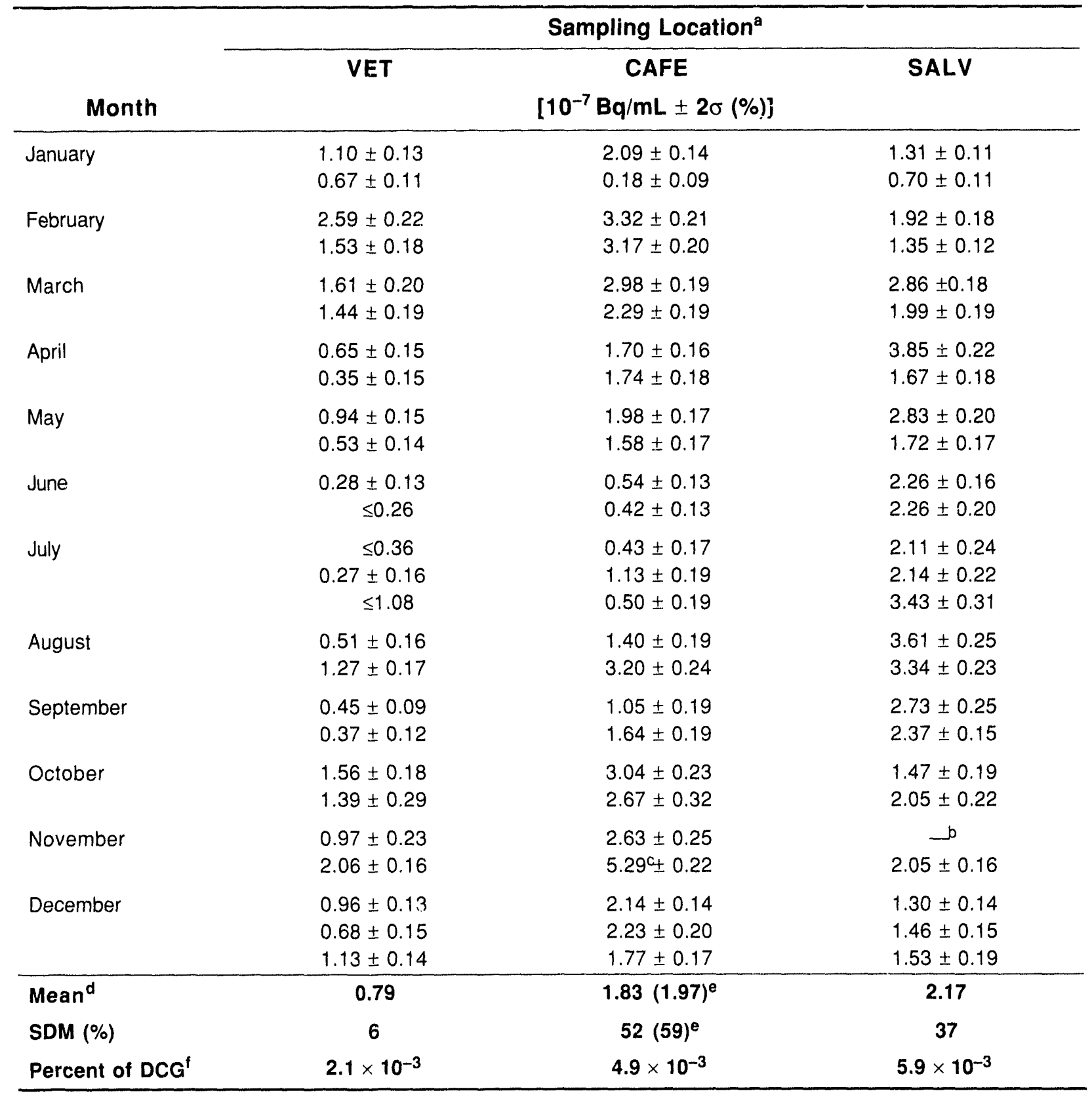

asee Fig. 4-6 for sampling locations.

bNo data; see Chapter 8.

cOutlier.

dLivermore site perimeter overall average $=1.60 \times 10^{-7} \mathrm{~Bq} / \mathrm{mL}$

eData with outlier included.

${ }^{\mathrm{I}} \mathrm{DCG}=3.7 \times 10^{-3} \mu \mathrm{Ci} / \mathrm{mL}$. 


\section{Environmental Monitoring Program Information}

Table 4-11. Tritium Concentrations Measured in Livermore Valley Surface Water Samples.

\begin{tabular}{|c|c|c|c|c|c|c|}
\hline \multirow[b]{3}{*}{ Quarter } & \multicolumn{6}{|c|}{ Sampling Location ${ }^{a}$} \\
\hline & DEL $^{b}$ & ZON7 ${ }^{b}$ & DUCK $^{b}$ & GAS $^{\mathbf{C}}$ & ALAG ${ }^{b}$ & SHAD \\
\hline & \multicolumn{6}{|c|}{$[B q / L \pm 2 \sigma(\%)]$} \\
\hline First & $1.41 \pm 0.11$ & $0.94 \pm 0.08$ & $2.82 \pm 0.18$ & $1.66 \pm 0.12$ & $1.00 \pm 0.09$ & $3.67 \pm 0.23$ \\
\hline Second & $0.90 \pm 0.09$ & $0.66 \pm 0.07$ & $2.67 \pm 0.20$ & $0.75 \pm 0.08$ & $1.15 \pm 0.10$ & $3.39 \pm 0.23$ \\
\hline Third & $0.94 \pm 0.08$ & $0.25 \pm 0.08$ & $1.67 \pm 0.14$ & $1.33 \pm 0.15$ & $0.94 \pm 0.12$ & $3.08 \pm 0.18$ \\
\hline Fourth & $1.05 \pm 0.13$ & $0.87 \pm 0.14$ & & & $1.17 \pm 0.15$ & $3.89 \pm 0.22$ \\
\hline Mean & 1.08 & 0.68 & 2.39 & 1.25 & 1.06 & 3.51 \\
\hline SDM (\%) & 22 & 46 & 26 & 37 & 11 & 10 \\
\hline \multirow[t]{3}{*}{ Percent of DWS ${ }^{d}$} & 0.15 & 0.09 & 0.32 & 0.17 & 0.14 & 0.47 \\
\hline & \multicolumn{6}{|c|}{ Sampling Location ${ }^{a}$} \\
\hline & $\mathrm{CAL}^{\mathrm{b}}$ & TAPe & PALM $^{\mathrm{C}}$ & $\mathrm{ORCH}^{\prime}$ & BELLC & POOLg \\
\hline Quarter & \multicolumn{6}{|c|}{$[B q / L \pm 2 \sigma(\%)]$} \\
\hline \multirow[t]{2}{*}{ First } & $0.61 \pm 0.07$ & $0.97 \pm 0.14$ & $0.64 \pm 0.08$ & $0.94 \pm 0.09$ & $0.95 \pm 0.63$ & $21.39 \pm 1.78$ \\
\hline & $0.75 \pm 0.11$ & $0.23 \pm 0.05$ & $0.68 \pm 0.12$ & $0.49 \pm 0.10$ & $0.98 \pm 0.13$ & $22.72 \pm 1.75$ \\
\hline \multirow[t]{3}{*}{ Second } & $0.92 \pm 0.13$ & $0.83 \pm 0.10$ & $0.58 \pm 0.11$ & $0.51 \pm 0.11$ & $1.08 \pm 0.13$ & $22.57 \pm 1.74$ \\
\hline & & $0.61 \pm 0.11$ & & & & $22.98 \pm 1.79$ \\
\hline & & $0.72 \pm 0.13$ & & & & $19.20 \pm 2.15$ \\
\hline \multirow[t]{4}{*}{ Third } & & $1.02 \pm 0.13$ & & & & $17.43 \pm 2.09$ \\
\hline & & $0.90 \pm 0.16$ & & & & $15.47 \pm 2.09$ \\
\hline & & & & & & $10.99 \pm 2.21$ \\
\hline & & & & & & $7.81 \pm 1.09$ \\
\hline \multirow[t]{2}{*}{ Fourth } & & & & & & $9.36 \pm 1.47$ \\
\hline & & & & & & $12.62 \pm 1.99$ \\
\hline Mean & 0.76 & 0.75 & 0.63 & 0.65 & 1.00 & 16.60 \\
\hline SDM (\%) & 20 & 36 & 8 & 39 & 7 & 34 \\
\hline Percent of DWS & 0.10 & 0.10 & 0.08 & 0.09 & 0.14 & 2.24 \\
\hline
\end{tabular}

aSee Fig. 4-10 for sampling locations.

bSurface water.

cTap water-Livermore locations.

dDWS $=750 \mathrm{~Bq} / \mathrm{L}\left(2 \times 10^{-5} \mu \mathrm{Ci} / \mathrm{mL}\right)$.

eTap water-LLNL.

'Well water.

gLLNL swimming pool. 


\section{Environmental Monitoring Program Information}

Table 4-12. Tritium in Rain, Measured at the Livermore Site and in the Livermore Valley.

\begin{tabular}{|c|c|c|c|c|c|c|c|}
\hline \multirow[b]{2}{*}{ Date } & \multicolumn{7}{|c|}{ Sampling Location ${ }^{a}$} \\
\hline & VIS & SALV & ZON7 & $\begin{array}{c}\text { AQUE } \\
{[B q / L \pm 2 \sigma(\%)}\end{array}$ & BVA & VINE & PARK \\
\hline $01 / 07 / 92$ & $11.77 \pm 1.88$ & $19.39 \pm 2.09$ & $-b$ & $8.29 \pm 1.77$ & $\leq 304$ & $\leq 304$ & $\leq 296$ \\
\hline $01 / 30 / 92$ & $2.66 \pm 1.65$ & $5.29 \pm 1.77$ & $3.11 \pm 1.67$ & $6.51 \pm 1.81$ & $8.03 \pm 1.86$ & $10.29 \pm 3.42$ & $3.81 \pm 1.70$ \\
\hline $02 / 05 / 92$ & $17.09 \pm 1.57$ & $40.70 \pm 2.44$ & $18.32 \pm 2.20$ & $16.35 \pm 2.11$ & $9.62 \pm 1.74$ & $15.84 \pm 2.12$ & $2.73 \pm 1.08$ \\
\hline $02 / 08 / 92$ & $12.58 \pm 1.86$ & $20.05 \pm 1.62$ & $8.03 \pm 1.20$ & $16.10 \pm 1.53$ & $25.75 \pm 1.91^{c}$ & $7.03 \pm 2.50$ & $7.03 \pm 2.41$ \\
\hline $02 / 11 / 92$ & $8.21 \pm 1.76$ & $6.33 \pm 1.68$ & $4.44 \pm 1.46$ & $4.74 \pm 1.63$ & $6.51 \pm 1.70$ & $0.93 \pm 0.92$ & $\leq 234$ \\
\hline $02 / 12 / 92$ & $5.40 \pm 1.73$ & $8.70 \pm 1.79$ & $3.50 \pm 1.57$ & $12.32 \pm 1.97$ & $4.37 \pm 1.71$ & $1.85 \pm 1.51$ & $1.89 \pm 1.60$ \\
\hline $02 / 12 / 92$ & $9.92 \pm 1.77$ & $20.87 \pm 1.69$ & $6.99 \pm 2.46$ & $14.54 \pm 1.92$ & $2.38 \pm 1.64$ & $4.66 \pm 1.71$ & $2.09 \pm 1.62$ \\
\hline $02 / 18 / 92$ & $7.88 \pm 1.76$ & $16.50 \pm 2.03$ & $5.22 \pm 1.66$ & $11.88 \pm 1.90$ & $11.14 \pm 1.86$ & $13.73 \pm 1.95$ & $2.25 \pm 1.55$ \\
\hline $02 / 19 / 92$ & $23.24 \pm 2.32$ & $13.14 \pm 2.02$ & $14.32 \pm 1.43$ & $27.60 \pm 2.43$ & $1.87 \pm 1.65$ & $\leq 186$ & $\leq 234$ \\
\hline $02 / 20 / 92$ & $19.54 \pm 2.21$ & $48.84 \pm 2.93^{c}$ & $17.58 \pm 2.14$ & $19.68 \pm 2.22$ & $10.73 \pm 2.62$ & $2.85 \pm 1.68$ & $\leq 314$ \\
\hline $03 / 03 / 92$ & $5.96 \pm 1.76$ & $10.25 \pm 1.90$ & $3.61 \pm 1.62$ & $9.44 \pm 1.87$ & $\leq 314$ & $\leq 304$ & $\leq 316$ \\
\hline $03 / 06 / 92$ & $22.09 \pm 2.21$ & $37.74 \pm 2.60$ & $12.91 \pm 1.94$ & $53.28 \pm 2.98^{c}$ & $2.30 \pm 1.56$ & $2.18 \pm 1.55$ & $\leq 304$ \\
\hline $03 / 17 / 92$ & $8.18 \pm 1.24$ & $17.09 \pm 2.02$ & $5.96 \pm 1.75$ & $11.21 \pm 1.33$ & $6.51 \pm 1.16$ & $10.40 \pm 1.90$ & $\leq 188$ \\
\hline $03 / 26 / 92$ & $20.31 \pm 1.63$ & $19.80 \pm 2.22$ & $9.51 \pm 1.26$ & $18.61 \pm 2.20$ & $8.44 \pm 1.26$ & $6.33 \pm 1.15$ & $3.19 \pm 1.32$ \\
\hline 04/13/92 & $10.77 \pm 1.95$ & $24.24 \pm 2.33$ & $6.88 \pm 1.75$ & $26.34 \pm 2.40$ & $\leq 304$ & $1.71 \pm 1.55$ & $\leq 298$ \\
\hline $06 / 30 / 92$ & $11.06 \pm 2.39$ & $22.83 \pm 2.79$ & $8.03 \pm 2.29$ & $30.86 \pm 2.99$ & $\leq 406$ & $-b$ & $\leq 396$ \\
\hline $11 / 22 / 92$ & $21.57 \pm 2.76$ & $23.13 \pm 2.80$ & $7.03 \pm 2.21$ & $20.02 \pm 2.72$ & $\leq 384$ & $-b$ & $\leq 396$ \\
\hline $12 / 04 / 92$ & $4.26 \pm 1.72$ & $4.85 \pm 1.97$ & $\leq 1.61 \pm 1.61$ & $5.92 \pm 1.79$ & $6.88 \pm 1.83$ & $6.48 \pm 1.79$ & $2.45 \pm 1.65$ \\
\hline $12 / 10 / 92$ & $26.79 \pm 2.81$ & $21.68 \pm 2.67$ & $13.73 \pm 2.40$ & $17.80 \pm 2.54$ & $\leq 388$ & $\leq 396$ & $2.92 \pm 2.69$ \\
\hline $12 / 15 / 92$ & $11.84 \pm 2.38$ & $33.93 \pm 3.05$ & $12.25 \pm 1.58$ & $26.53 \pm 2.04$ & $3.13 \pm 2.06$ & $3.50 \pm 2.07$ & $\leq 248$ \\
\hline Meand & 13.01 & $\begin{array}{c}19.29 \\
(20.77)^{\mathrm{e}}\end{array}$ & 8.66 & $\begin{array}{c}16.04 \\
(17.90)^{\mathrm{e}}\end{array}$ & $5.42(6.43)^{e}$ & 4.15 & $2.92^{f}$ \\
\hline SDM (\%) & 54 & $53(56)^{\theta}$ & 56 & $48(63)^{e}$ & $55(84)^{e}$ & 53 & $16^{d}$ \\
\hline
\end{tabular}

asee Fig. 4-11 for sampling locations.

bNo data.

COutlier.

$d_{\text {Mean absolute deviation (\%). }}$

eData with outlier included.

'Median value. 


\section{Environmental Monitoring Program Information}

Table 4-13. Gross Alpha and Beta Activity Measured in Livermore Valley Surface Water Samples.

\begin{tabular}{|c|c|c|c|c|c|}
\hline \multirow{3}{*}{$\frac{\text { Locationa }}{D E L}$} & \multirow{2}{*}{\multicolumn{2}{|c|}{$\begin{array}{c}\text { Gross alpha Gross beta } \\
{\left[10^{-\circ} \mu \mathrm{Ci} / \mathrm{mL} \pm 2 \sigma(\%)\right]}\end{array}$}} & \multirow[b]{2}{*}{ Locationa } & Gross alpha & \multirow{2}{*}{$\begin{array}{l}\text { Gross beta } \\
\pm 2 \sigma(\%)]\end{array}$} \\
\hline & & & & {$\left[10^{-9} \mu \mathrm{Ci} / \mathrm{mL} \pm 2 \sigma(\%)\right]$} & \\
\hline & $\leq 0.08$ & $0.15 \pm 0.07$ & TAP & $\leq 0.03$ & $\leq 0.09$ \\
\hline & $\leq 0.08$ & $\leq 0.10$ & & $\leq 0.03$ & $\leq 0.05$ \\
\hline & $\leq 0.08$ & $0.07 \pm 0.06$ & & $\leq 0.07$ & $\leq 0.11$ \\
\hline & $\leq 0.07$ & $0.07 \pm 0.06$ & & $\leq 0.03$ & $\leq 0.02^{b}$ \\
\hline \multirow[t]{4}{*}{ ZON7 } & $\leq 0.07$ & $9.70 \pm 0.28^{b}$ & PALM & $\leq 0.06$ & $\leq 0.10$ \\
\hline & $\leq 0.09$ & $\leq 0.16$ & & $-0.08 \pm 0.05$ & $\leq 0.13$ \\
\hline & $\leq 0.10$ & $0.24 \pm 0.08$ & & $\leq 0.18$ & $0.09 \pm 0.08$ \\
\hline & $\leq 0.09$ & $0.08 \pm 0.05$ & & $\leq 0.07$ & $0.10 \pm 0.05$ \\
\hline \multirow[t]{4}{*}{ DUCK } & $0.42 \pm 0.39$ & $\leq 0.34$ & $\mathrm{ORCH}$ & $\leq 0.23$ & $\leq 0.22$ \\
\hline & $\leq 0.30$ & $\leq 0.23$ & & $\leq 0.25$ & $\leq 0.22$ \\
\hline & $\leq 0.09$ & $0.45 \pm 0.30$ & & $0.20 \pm 0.18$ & $0.08 \pm 0.07$ \\
\hline & $-^{c}$ & $c^{c}$ & & $\leq 0.17$ & $\leq 0.23$ \\
\hline \multirow[t]{4}{*}{ GAS } & $0.43 \pm 0.19$ & $7.43 \pm 0.25^{b}$ & BELL & $\leq 0.04$ & $0.09 \pm 0.06$ \\
\hline & $\leq 0.07$ & $0.09 \pm 0.06$ & & $\leq 0.02$ & $0.10 \pm 0.07$ \\
\hline & $\leq 0.08$ & $\leq 0.11$ & & $\leq 0.11$ & $\leq 0.22$ \\
\hline & $\leq 0.18$ & $\leq 0.08$ & & $\leq 0.04$ & $0.07 \pm 0.05$ \\
\hline \multirow[t]{4}{*}{ ALAG } & $\leq 0.10$ & $0.11 \pm 0.07$ & POOL & $\leq 0.18$ & $0.16 \pm 0.08$ \\
\hline & $\leq 0.09$ & $\leq 0.07$ & & - & $-c$ \\
\hline & $\leq 0.07$ & $\leq 0.07$ & & $\leq 0.16$ & $0.46 \pm 0.26$ \\
\hline & $\leq 0.13$ & $0.10 \pm 0.05$ & & $\leq 0.04$ & $\leq 0.14$ \\
\hline \multirow[t]{4}{*}{ SHAD } & $\leq 0.09$ & $0.13 \pm 0.07$ & & $\leq 0.02$ & $0.14 \pm 0.09$ \\
\hline & $\leq 0.16$ & $0.11 \pm 0.08$ & & $\leq 0.16$ & $0.13 \pm 0.07$ \\
\hline & $\leq 0.16$ & $0.08 \pm 0.06$ & & $\leq 0.32$ & $0.37 \pm 0.15$ \\
\hline & $\leq 0.29$ & $\leq 0.09$ & & $\leq 0.07$ & $0.15 \pm 0.08$ \\
\hline \multirow[t]{6}{*}{ CAL } & $\leq 0.10$ & $0.07 \pm 0.06$ & & $\leq 0.36$ & $0.39 \pm 0.28$ \\
\hline & $\leq 0.08$ & $\leq 0.16$ & & $\leq 0.40$ & $0.48 \pm 0.15$ \\
\hline & $-0.07 \pm 0.06$ & $\leq 0.10$ & & $\leq 0.37$ & $0.16 \pm 0.13$ \\
\hline & $\leq 0.05$ & $\leq 0.10$ & & $\leq 0.29$ & $0.61 \pm 0.17$ \\
\hline & & & $\begin{array}{l}\text { Mean } \\
\text { (overall) }\end{array}$ & $\leq 0.09^{d}$ & $0.135(0.152)^{e}$ \\
\hline & & & SDM (overall) & $61^{4}$ & $72(1347)^{e}$ \\
\hline
\end{tabular}

aSee Fig. 4-10 for sampling locations.

bOutlier.

cNo data.

Median.

eData with outliers included.

Median absolute deviation. 


\section{Environmental Monitoring Program Information}

Table 4-14. Tritium Concentrations Measured in Livermore Valley Groundwater Samples.

\begin{tabular}{|c|c|c|c|}
\hline Well Identification $^{a}$ & $\begin{array}{c}\text { Activity } \\
\text { (Bq/L) }\end{array}$ & $\begin{array}{c}\text { Error } \\
(\mathrm{Bq} / \mathrm{L})\end{array}$ & Percent of DWS \\
\hline \multicolumn{4}{|l|}{ Location T3SR1E } \\
\hline $1 \mathrm{H3}$ & 0.39 & 0.11 & 0.05 \\
\hline $1 \mathrm{P} 2$ & 4.92 & 0.27 & 0.67 \\
\hline $1 \mathrm{P} 3$ & 0.73 & 0.11 & 0.10 \\
\hline 1R2 & 2.95 & 0.18 & 0.40 \\
\hline $2 \mathrm{R} 1$ & 6.51 & 0.31 & 0.88 \\
\hline $9 \mathrm{M} 2$ & 1.59 & 0.14 & 0.22 \\
\hline 9M2 duplicate & 1.24 & 0.18 & 0.17 \\
\hline $11 \mathrm{B1}$ & 16.95 & 0.54 & 2.29 \\
\hline $12 A 2$ & 2.59 & 0.21 & 0.35 \\
\hline $12 \mathrm{G} 1$ & $-c$ & $-c$ & $-c$ \\
\hline $16 \mathrm{~L} 5$ & 1.41 & 0.15 & 0.19 \\
\hline $16 \mathrm{~L} 7$ & 0.96 & 0.14 & 0.13 \\
\hline $16 L 7$ duplicate & 0.90 & 0.12 & 0.12 \\
\hline $3 \mathrm{~S} 1 \mathrm{E} 18 \mathrm{~A} 1$ & 0.92 & 0.12 & 0.12 \\
\hline 3S1E18A5 & - & $-c$ & -6 \\
\hline \multicolumn{4}{|l|}{ Location T3SR2E } \\
\hline $7 \mathrm{C} 2$ & 4.22 & 0.22 & 0.57 \\
\hline $7 \mathrm{P3}$ & $0.06^{d}$ & 0.06 & 0.01 \\
\hline 7P3 duplicate & $0.08^{d}$ & 0.07 & 0.01 \\
\hline $8 \mathrm{~F} 1$ & 1.35 & 0.13 & 0.18 \\
\hline $8 \mathrm{P} 1$ & 2.29 & 0.19 & 0.31 \\
\hline $9 \mathrm{Q} 1$ & 0.62 & 0.10 & 0.08 \\
\hline 16B1 & 1.60 & 0.15 & 0.22 \\
\hline Mean & $1.78(1.29)^{e}$ & - & - \\
\hline SDM & $142(294)^{e}$ & - & - \\
\hline
\end{tabular}

aSee Fig. 4-12 for sampling locations.

bDWS $=750 \mathrm{~Bq} / \mathrm{L}\left(2 \times 10^{-5} \mu \mathrm{Ci} / \mathrm{mL}\right)$

cNo data.

dOutlier.

eData with outlier included. 


\section{Environmental Monitoring Program Information}

Table 4-15. Various Radionuclides Measured in Storm-water Runoff at the Livermore Site.

\begin{tabular}{|c|c|c|c|}
\hline Location $^{\mathrm{a}}$ & $\begin{array}{c}{ }^{3} H \\
{[B q / L \pm 2 \sigma(\%)]}\end{array}$ & $\begin{array}{c}\text { Gross alpha } \\
{[B q / L-2 \sigma(\%)]}\end{array}$ & $\begin{array}{c}\text { Gross beta } \\
{[\mathrm{Bq} / \mathrm{L} \pm 2 \sigma(\%)]}\end{array}$ \\
\hline ASS & $\begin{aligned} & 8.29 \pm 1.78 \\
& 14.73 \pm 2.09 \\
& 2.00 \pm 1.63 \\
& 61.79 \pm 3.46 \\
& \leq 3.12 \\
& 7.62 \pm 1.57 \\
& 1.88 \pm 1.01 \\
& 13.28 \pm 1.45 \\
& 3.85 \pm 1.43 \\
& \leq 1.88 \\
& 16.02 \pm 2.05 \\
& 28.75 \pm 2.01 \\
& 48.84 \pm 2.78 \\
& \leq 3.50 \\
& 10.77 \pm 2.33 \\
& 3.10 \pm 2.01 \\
& \leq 4.04 \leq 3.96 \\
&\end{aligned}$ & 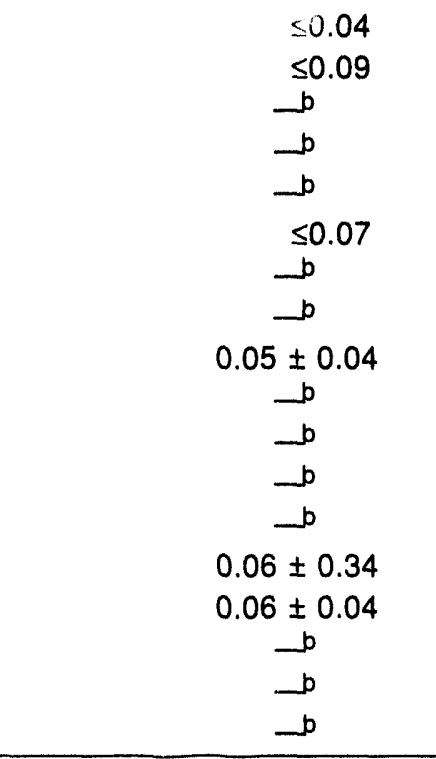 & 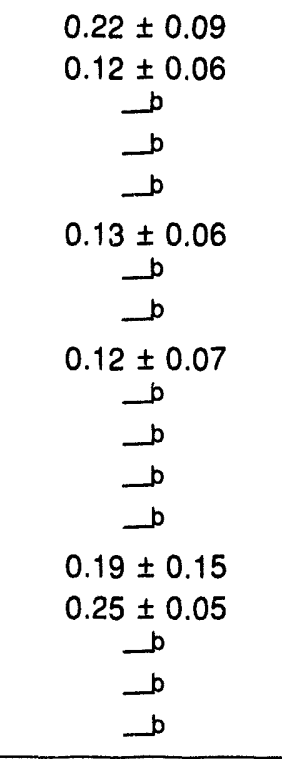 \\
\hline $\begin{array}{l}\text { Mean } \\
\text { SDM(\%) }\end{array}$ & $\begin{array}{c}7.21 \\
41\end{array}$ & $\begin{array}{l}\leq 0.06^{c} \\
42^{d}\end{array}$ & $\begin{array}{c}0.17 \\
33\end{array}$ \\
\hline $\begin{array}{l}\text { aSee Fig. 4-14 for s } \\
\text { bNo data. } \\
\text { Table 4-16. } \\
\text { Location }\end{array}$ & Parameter & $\begin{array}{c}\text { cMedian. } \\
\text { dMedian absolute dev } \\
\text { Onradioactive Parar } \\
\text { Concentration (mg/L) }\end{array}$ & \\
\hline \multicolumn{2}{|c|}{ Physical (mg/L) } & & \\
\hline $\begin{array}{l}\text { Bicarbonate Alk } \\
\text { Chemical Oxyg } \\
\text { Chloride } \\
\text { Fluoride } \\
\text { Nitrate plus Nit } \\
\text { Sulfate }\end{array}$ & $\left.\mathrm{O}_{3}\right)$ & $\begin{array}{l}30,30,30,20,19,22 \\
25,150,40,110,90,40 \\
1.2 \\
0.1 \\
3.1,4.2,1.0,3.2,1.9,4.8 \\
9.0,12.0,5.0\end{array}$ & \\
\hline \multicolumn{4}{|l|}{ Organics } \\
\hline $\begin{array}{l}\text { Toluene }(\mathrm{mg} / \mathrm{L}) \\
\text { Bis(2-ethyhexy } \\
\text { Total Organic C } \\
\text { Oil and Grease }\end{array}$ & $\begin{array}{l}e(\mathrm{mg} / \mathrm{L}) \\
\mathrm{gg} / \mathrm{L})\end{array}$ & $\begin{array}{l}1.3,0.8 \\
37 \\
6.0,13.0,6.7,4.9,18.0,9.5 \\
10,5\end{array}$ & \\
\hline
\end{tabular}

aSee Fig. 4-14 for sampling locations.

4-40 SNL/CA Site Environmental Report for 1992 


\section{Environmental Monitoring Program Information}

Table 4-17. Radionuclides Measured in Soil and Arroyo Sediments.

\begin{tabular}{|c|c|c|c|c|}
\hline \multicolumn{2}{|r|}{ Soll } & \multicolumn{3}{|c|}{ Arroyo Sediments } \\
\hline Location $^{a}$ & 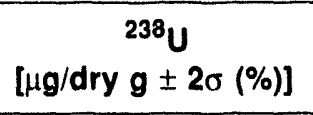 & Location $^{a}$ & $\begin{array}{c}{ }^{3} \mathrm{H} \\
\left(\mathrm{Bq} / \mathrm{L}^{\mathrm{b}}\right)\end{array}$ & $\begin{array}{c}238 \mathrm{U} \\
{[\mu \mathrm{g} / \mathrm{dry} \mathrm{g} \pm 2 \sigma(\%)]}\end{array}$ \\
\hline VIS & $2.5 \pm 2.3$ & ASS-2 & $5.2 \pm 1.5$ & $3.3 \pm 1.8$ \\
\hline PATT & $2.9 \pm 2.6$ & & $6.8 \pm 1.1$ & $<1.9$ \\
\hline ZON7 & $4.4 \pm 2.9$ & & $4.7 \pm 1.1$ & $2.6 \pm 1.3$ \\
\hline FCC & $2.4 \pm 1.6$ & & & \\
\hline HOSP & $1.9 \pm 1.2$ & & & \\
\hline TANK & $<1.8$ & & & \\
\hline ALTA & $<2.5$ & & & \\
\hline ERCH & $2.2 \pm 1.1$ & & & \\
\hline $\mathrm{RRCH}$ & $<1.2$ & & & \\
\hline Mean & 2.4 & & 5.6 & 2.6 \\
\hline SDM $(\%)$ & 37 & & 20 & 27 \\
\hline
\end{tabular}

aSee Figs. 4-14 and 4-15 for sampling locations.

bMedian value; see Chapter 8 .

Table 4-18. Positively Detected Metals in Arroyo Sediments Near the Livermore Site (mg/L). ${ }^{a}$

\begin{tabular}{|c|c|c|c|c|c|c|c|c|c|c|}
\hline Location $^{b}$ & As & $\mathbf{B a}$ & $\mathrm{Ca}$ & Total $\mathrm{Cr}$ & Co & $\mathrm{Cu}$ & $\mathrm{Pb}$ & $\mathrm{Ni}$ & v & $\mathrm{Zn}$ \\
\hline \multirow[t]{3}{*}{ ASS-2 } & 0.02 & 6.8 & 0.24 & 0.08 & 0.22 & 0.11 & 3.4 & 0.4 & 0.21 & 0.48 \\
\hline & 0.03 & 6.7 & $\leq 0.05$ & 0.06 & 0.23 & 0.10 & $\leq 0.2$ & 0.4 & 0.23 & 0.66 \\
\hline & 0.03 & 7.2 & $\leq 0.05$ & $\leq 0.05$ & 0.17 & 0.12 & $\leq 0.2$ & 0.4 & 0.18 & 0.43 \\
\hline Mean & 0.03 & 6.9 & $\leq 0.05^{c}$ & 0.06 & 0.21 & 0.11 & $\leq 0.02^{c}$ & 0.4 & 0.21 & 0.52 \\
\hline SDM $(\%)$ & 22 & 4 & $0^{d}$ & 24 & 16 & 9 & $0^{d}$ & 0 & 12 & 23 \\
\hline
\end{tabular}




\section{Environmental Monitoring Program Information}

Table 4-19. Positively Detected Organic Compounds in Arroyo Sediments Near the Livermore Site $(\mathbf{m g} / \mathbf{k g})$.

\begin{tabular}{|c|c|c|c|c|c|c|c|}
\hline Location $^{a}$ & $\begin{array}{l}\text { Carbon } \\
\text { tetrachlorlde }\end{array}$ & Chloroform & $\begin{array}{l}\text { Methylene } \\
\text { chloride }\end{array}$ & $p, p^{\prime}-D D E$ & Toluene & $\begin{array}{l}\text { Total xylene } \\
\text { isomers }\end{array}$ & $\begin{array}{l}\text { Trichloro- } \\
\text { fluoromethane }\end{array}$ \\
\hline \multirow[t]{3}{*}{ ASS-2 } & 0.0002 & 0.0002 & 0.0066 & $\leq 0.002$ & 0.004 & $\leq 0.002$ & $\leq 0.0002$ \\
\hline & 0.0002 & 0.0002 & 0.0064 & 0.003 & 0.011 & $\leq 0.002$ & 0.0004 \\
\hline & $\leq 0.0002$ & $\leq 0.0002$ & 0.002 & $\leq 0.002$ & 0.004 & 0.004 & $\leq 0.0002$ \\
\hline Mean & 0.0002 & 0.0002 & 0.005 & $\leq 0.002^{b}$ & 0.006 & $\leq 0.002^{b}$ & $\leq 0.002^{b}$ \\
\hline SDM (\%) & 0 & 0 & 52 & $0^{c}$ & 64 & $0^{c}$ & $0^{c}$ \\
\hline
\end{tabular}

aSee Fig. 4-14 for sampling locations.

bMedian.

cMedian Absolute Deviation.

Table 4-20. Tritium Concentrations Measured in Livermore Valley Vegetation.

\begin{tabular}{|c|c|c|c|c|c|c|c|c|}
\hline \multirow[b]{2}{*}{ Quarter } & \multicolumn{8}{|c|}{ Sampling Location ${ }^{a}$} \\
\hline & PATT & ZON7 & $\begin{array}{l}1580 \\
{[\mathrm{~Bq} / \mathrm{L} C}\end{array}$ & $\begin{array}{l}\text { AQUE } \\
\text { of moisture }\end{array}$ & $\begin{array}{c}\text { RAlL } \\
\text { content } \pm 2\end{array}$ & $\begin{array}{c}\text { FCC } \\
2 \sigma(\%)]\end{array}$ & TESW & MET \\
\hline First & $4.44 \pm 0.92$ & $9.18 \pm 1.11$ & $6.18 \pm 1.00$ & $22.61 \pm 1.51$ & $24.98 \pm 1.62$ & $1.35 \pm 0.82$ & $25.2 \pm 1.56$ & $19.68 \pm 1.42$ \\
\hline Second & $3.81 \pm 1.72$ & $9.29 \pm 1.91$ & $2.62 \pm 2.20$ & $28.71 \pm 2.50$ & $18.46 \pm 2.22$ & $1.67 \pm 1.16$ & $6.18 \pm 1.80$ & $9.77 \pm 1.92$ \\
\hline Third & $8.58 \pm 1.89$ & $7.16 \pm 1.80$ & $18.91 \pm 2.27$ & $36.04 \pm 2.67$ & $24.90 \pm 2.37$ & $3.15 \pm 1.64$ & $12.6 \pm 1.99$ & $13.84 \pm 2.03$ \\
\hline Fourth & $4.11 \pm 2.05$ & $13.28 \pm 2.35$ & $9.10 \pm 3.13$ & $30.56 \pm 2.96$ & $7.07 \pm 2.14$ & $\leq 4.36$ & $4.00 \pm 203$ & $9.55 \pm 2.23$ \\
\hline Mean & 5.24 & 9.72 & 9.20 & 29.48 & 18.85 & 2.63 & 12.00 & 13.21 \\
\hline SDM $(\%)$ & 43 & 26 & 76 & 19 & 45 & 53 & 80 & 36 \\
\hline $\begin{array}{l}\text { Effective dose } \\
\text { (mSv) }\end{array}$ & $5.7 \times 10^{-6}$ & $1.1 \times 10^{-5}$ & $9.9 \times 10^{-6}$ & $3.2 \times 10^{-5}$ & $2.0 \times 10^{-5}$ & $2.8 \times 10^{-6}$ & $1.3 \times 10^{-5}$ & $1.4 \times 10^{-5}$ \\
\hline $\begin{array}{l}\text { Effective dose } \\
\text { (mrem) }\end{array}$ & $5.7 \times 10^{-4}$ & $1.1 \times 10^{-3}$ & $9.9 \times 10^{-4}$ & $3.2 \times 10^{-3}$ & $2.0 \times 10^{-3}$ & $2.8 \times 10^{-4}$ & $1.3 \times 10^{-3}$ & $1.4 \times 10^{-3}$ \\
\hline
\end{tabular}

aSee Fig. 4-16 for sampling locations.

bThis dose represents the total effective dose from the forage-cow-milk pathway. 


\section{Environmental Monitoring Program Information}

Table 4-21. Tritium Concentrations Measured in Retail Wines.a

\begin{tabular}{|c|c|c|c|}
\hline \multirow[b]{2}{*}{ Sample } & \multicolumn{3}{|c|}{ Area of Production } \\
\hline & Livermore Valley & California (Non-Livermore Valley) & Europe \\
\hline & \multicolumn{3}{|c|}{$[B q / L \pm 2 \sigma(\%)]$} \\
\hline 1 & $2.29 \pm 0.18$ & $1.44 \pm 0.13$ & $2.24 \pm 0.14$ \\
\hline 2 & $8.60 \pm 0.37$ & $0.61 \pm 0.12$ & $2.63 \pm 0.16$ \\
\hline 3 & $3.22 \pm 0.23$ & $0.91 \pm 0.13$ & $1.84 \pm 0.14$ \\
\hline 4 & $8.84 \pm 0.48$ & $0.68 \pm 0.12$ & $3.20 \pm 0.17$ \\
\hline 5 & $7.96 \pm 0.56$ & & $10.94 \pm 1.11$ \\
\hline 6 & $8.43 \pm 0.38$ & & $1.43 \pm 0.12$ \\
\hline 7 & $4.21 \pm 0.26$ & & \\
\hline 8 & $3.10 \pm 0.26$ & & \\
\hline 9 & $2.94 \pm 0.17$ & & \\
\hline 10 & $1.07 \pm 0.17$ & & \\
\hline 11 & $2.75 \pm 0.19$ & & \\
\hline 12 & $2.62 \pm 0.60$ & & \\
\hline Mean & 3.86 & 0.91 & 3.71 \\
\hline SDM (\%) & 50 & 41 & 97 \\
\hline
\end{tabular}

aConcentration is expressed in becquerels per liter $(\mathrm{Bq} / \mathrm{L})$. An explanation of radiological units is provided in the glossary.

Table 4-22. Tritium Concentrations Measured in Livermore Valley Honey.

\begin{tabular}{|c|c|c|}
\hline \multirow[b]{2}{*}{ Sample } & \multicolumn{2}{|c|}{$\begin{array}{c}\text { Sampling Location } \\
{[\mathrm{Bq} / \mathrm{L} \text { (in water recovered) } \pm 2 \sigma(\%)]}\end{array}$} \\
\hline & Livermore & California \\
\hline 1 & $1.65 \pm 0.56$ & $27.71 \pm 1.33$ \\
\hline 2 & $6.03 \pm 0.83$ & $1.10 \pm 0.69$ \\
\hline 3 & $3.50 \pm 0.90$ & $7.73 \pm 0.84$ \\
\hline Mean & 3.73 & 12.18 \\
\hline SDM (\%) & 59 & 114 \\
\hline
\end{tabular}




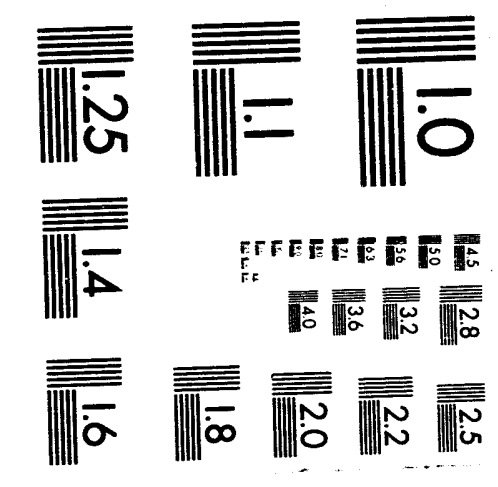



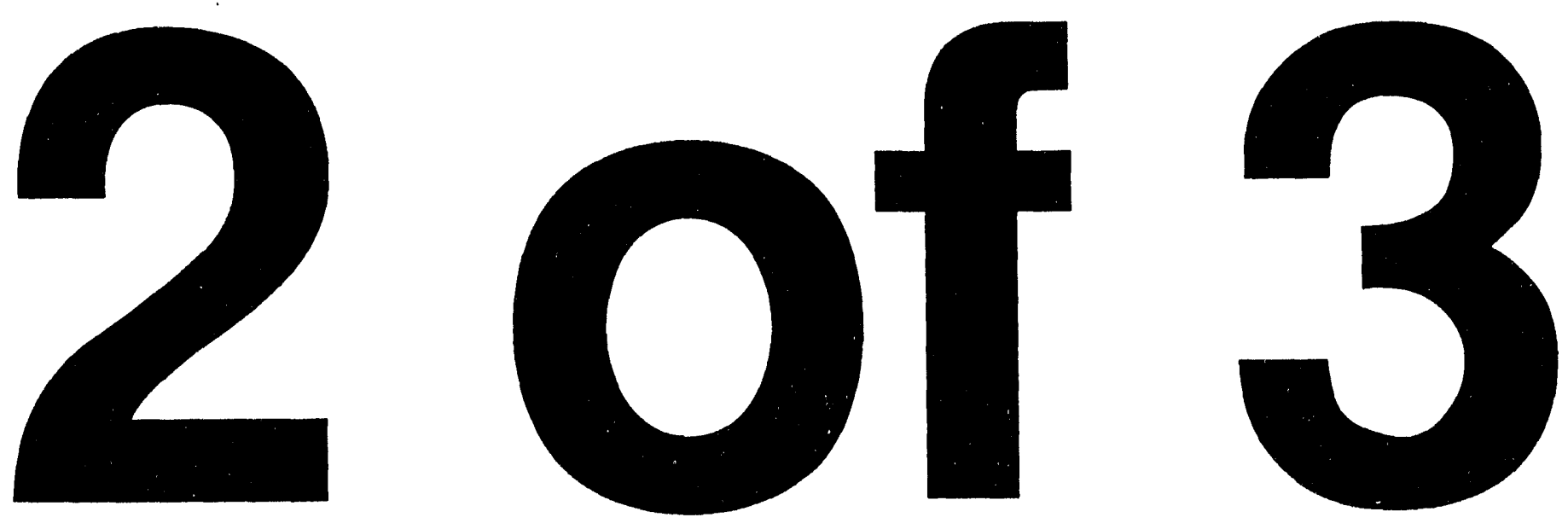


\section{Environmental Monitoring Program Information}

Table 4-23. Tritium Concentrations Measured in Livermore Valley Goat Milk.

\begin{tabular}{|c|c|c|c|c|c|c|c|}
\hline \multirow[b]{2}{*}{ Month } & \multicolumn{7}{|c|}{ Sampling Location } \\
\hline & WRDa $^{a}$ & MZFa & LUPa & $\begin{array}{c}\operatorname{COOL}^{a} \\
q / L \pm 2 \sigma(\%)\end{array}$ & MOD' & TUR $^{b}$ & CARTC \\
\hline February & $-d$ & $4.81 \pm 1.44$ & $4.96 \pm 1.08$ & $3.74 \pm 1.05$ & $-e$ & $5.44 \pm 1.11$ & $2.01 \pm 0.99$ \\
\hline March & $1.61 \pm 1.60$ & $\leq$ & $2.56 \pm 1.64$ & $\leq 3.08$ & - & $2.76 \pm 1.64$ & $\leq 3.16$ \\
\hline April & $\leq 3.22$ & 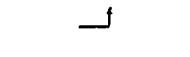 & $\leq 4.62$ & $2.26 \pm 1.66$ & $\leq 3.18$ & $2.42 \pm 1.67$ & $2.76 \pm 1.69$ \\
\hline May & $1.51 \pm 1.21$ & 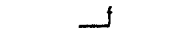 & $1.92 \pm 0.96$ & $2.96 \pm 0.99$ & $3.60 \pm 1.06$ & $1.55 \pm 1.28$ & $3.01 \pm 1.02$ \\
\hline June & $2.78 \pm 1.73$ & $-f$ & $3.26 \pm 1.78$ & $\leq 1.30$ & $2.60 \pm 1.73$ & $\leq 4.82$ & $\leq 1.40$ \\
\hline July & $\leq 3.28$ & $\dashv$ & $2.08 \pm 1.69$ & $\leq 1.32$ & $\leq 1.30$ & $1.76 \pm 1.68$ & $2.67 \pm 1.70$ \\
\hline August & $2.56 \pm 1.85$ & $\rightarrow$ & $\rightarrow$ & $\leq 1.56$ & $\rightarrow$ & $2.92 \pm 1.85$ & $3.92 \pm 1.90$ \\
\hline September & $\leq 3.82$ & $-:$ & - & $\leq 1.76$ & $\dashv$ & $\leq 3.88$ & $\leq 3.84$ \\
\hline October & $\leq 4.02$ & 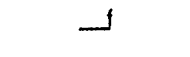 & $\rightarrow$ & $\leq 1.98$ & - & $2.92 \pm 2.05$ & $2.91 \pm 2.06$ \\
\hline November & $\leq 3.24$ & 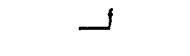 & $\longrightarrow$ & $-d$ & - & $1.78 \pm 1.63$ & $\leq 3.14$ \\
\hline Mean & $\leq 3.22 \mathrm{~g}$ & N/A & 3.23 & $\leq 1.98 \mathrm{~g}$ & 2.899 & 3.02 & 2.88 \\
\hline $\operatorname{SDM}(\%)$ & $19^{h}$ & N/A & 40 & $34^{h}$ & $17^{h}$ & 44 & 26 \\
\hline $\begin{array}{l}\text { Effective dose } \\
\text { (mSv) }\end{array}$ & $1.7 \times 10^{-5}$ & $2.6 \times 10^{-5}$ & $1.7 \times 10^{-5}$ & $1.0 \times 10^{-5}$ & $1.6 \times 10^{-5}$ & $1.6 \times 10^{-5}$ & $1.6 \times 10^{-5}$ \\
\hline $\begin{array}{l}\text { Effective dose } \\
\text { (mrem) }\end{array}$ & $1.7 \times 10^{-3}$ & $2.6 \times 10^{-3}$ & $1.7 \times 10^{-3}$ & $1.0 \times 10^{-3}$ & $1.6 \times 10^{-3}$ & $1.6 \times 10^{-3}$ & $1.6 \times 10^{-3}$ \\
\hline
\end{tabular}

aLivermore Valley sampling location.

bCalifornia (non-Livermore Valley) sampling location.

'Cartoned, store-bought sample.

dNo sample obtained; see Chapter 8.

eparticipation in monitoring program began mid-year.

tProvider discontinued participation in monitoring program.

gMedian value; see Chapter 8 .

hMedian absolute deviation see; Chapter 8. 


\section{Environmental Monitoring Program Information}

Table 4-24. Quarterly and Annual Environmental Radiation Measurements at Livermore Site Perimeter Locations.

\begin{tabular}{|c|c|c|c|c|c|}
\hline \multirow[b]{2}{*}{ Location $^{a}$} & Jan.-Mar. & Apr.-June & July-Sept. & Oct-Dec. & \multirow{2}{*}{$\begin{array}{l}\text { Annual } \\
\text { Total }\end{array}$} \\
\hline & \multicolumn{4}{|c|}{ (mSv) } & \\
\hline 11 & 0.14 & 0.13 & 0.12 & 0.14 & 0.53 \\
\hline 12 & 0.15 & 0.14 & 0.13 & 0.17 & 0.59 \\
\hline 14 & 0.16 & 0.15 & 0.15 & 0.18 & 0.64 \\
\hline 55 & 0.16 & 0.15 & 0.14 & 0.17 & 0.62 \\
\hline 56 & 0.16 & 0.16 & 0.15 & 0.17 & 0.64 \\
\hline 57 & 0.17 & 0.18 & 0.16 & 0.20 & 0.71 \\
\hline 58 & 0.17 & 0.16 & 0.15 & 0.18 & 0.65 \\
\hline 59 & 0.16 & 0.16 & 0.16 & 0.18 & 0.66 \\
\hline 60 & 0.17 & 0.16 & 0.16 & 0.17 & 0.66 \\
\hline 61 & 0.15 & 0.14 & 0.13 & 0.16 & 0.57 \\
\hline 63 & 0.16 & 0.16 & 0.16 & 0.18 & 0.66 \\
\hline 66 & 0.17 & 0.16 & 0.16 & 0.19 & 0.68 \\
\hline 67 & 0.15 & 0.16 & 0.15 & 0.17 & 0.63 \\
\hline 68 & 0.16 & 0.16 & 0.15 & 0.18 & 0.66 \\
\hline 69 & 0.15 & 0.15 & 0.14 & 0.16 & 0.61 \\
\hline$E 7001^{b}$ & 0.14 & 0.15 & 0.10 & 0.17 & 0.56 \\
\hline$E 7002^{b}$ & 0.14 & 0.15 & 0.10 & $0.21^{c}$ & 0.61 \\
\hline$E 7003^{b}$ & 0.13 & 0.13 & 0.10 & 0.17 & 0.51 \\
\hline$E 7004^{b}$ & 0.14 & 0.13 & 0.10 & 0.16 & 0.53 \\
\hline Mean & 0.15 & 0.15 & 0.14 & $0.17(0.17)^{d}$ & 0.62 \\
\hline Mean (mrem) & 15 & 15 & 14 & $17(17)^{d}$ & 62 \\
\hline SDM (\%) & 8 & 10 & 17 & $8(15)^{d}$ & 9 \\
\hline
\end{tabular}

asee Fig. 4-20 for sampling locations.

bThese dosimeters are collected by SNL/California personnel and are processed at SNL/New Mexico.

cOutlier.

dData with outlier included. 


\section{Environmental Monitoring Program Information}

Table 4-25. Quarterly Environmental Radiation Measurements at Livermore Valley Locations.

\begin{tabular}{|c|c|c|c|c|c|}
\hline \multirow[b]{2}{*}{ Location $^{a}$} & Jan.-Mar. & Apr.-June & July-Sept. & Oct.-Dec. & \multirow[b]{2}{*}{ Annual Tota } \\
\hline & \multicolumn{4}{|c|}{ (mSv) } & \\
\hline 15 & 0.16 & 0.15 & 0.14 & 0.18 & 0.63 \\
\hline 16 & 0.17 & 0.16 & 0.15 & 0.18 & 0.66 \\
\hline 17 & 0.17 & 0.16 & 0.15 & 0.18 & 0.66 \\
\hline 18 & 0.13 & 0.12 & 0.12 & 0.13 & $0.50^{b}$ \\
\hline 19 & 0.17 & 0.16 & 0.15 & -6 & $0.64^{d}$ \\
\hline 20 & 0.16 & 0.14 & 0.14 & $-c$ & $0.59^{d}$ \\
\hline 21 & 0.16 & 0.15 & 0.14 & 0.17 & 0.62 \\
\hline 22 & 0.17 & 0.17 & 0.16 & 0.19 & 0.70 \\
\hline 23 & 0.18 & 0.17 & 0.16 & 0.18 & 0.70 \\
\hline 24 & 0.17 & 0.17 & 0.16 & 0.19 & 0.70 \\
\hline 27 & 0.18 & 0.18 & 0.16 & 0.20 & 0.73 \\
\hline 28 & 0.18 & 0.19 & 0.17 & 0.21 & 0.75 \\
\hline 29 & 0.17 & 0.17 & 0.17 & 0.19 & 0.71 \\
\hline 30 & 0.16 & 0.16 & 0.16 & 0.18 & 0.66 \\
\hline 31 & 0.16 & $-c$ & 0.15 & 0.17 & $0.64^{d}$ \\
\hline 32 & 0.16 & $-c$ & 0.15 & 0.18 & $0.65^{d}$ \\
\hline 33 & 0.17 & 0.17 & - & 0.18 & $0.69^{d}$ \\
\hline 34 & 0.18 & 0.18 & 0.17 & 0.20 & 0.72 \\
\hline 35 & 0.17 & 0.17 & 0.16 & 0.19 & 0.69 \\
\hline 36 & 0.17 & 0.18 & 0.18 & $0.94^{b}$ & $1.47^{d}$ \\
\hline 37 & 0.16 & 0.17 & 0.15 & 0.18 & 0.66 \\
\hline 38 & 0.17 & 0.18 & 0.16 & 0.18 & 0.70 \\
\hline 41 & 0.16 & 0.16 & $-c$ & 0.18 & $0.67^{d}$ \\
\hline 43 & 0.17 & 0.17 & 0.16 & 0.19 & 0.69 \\
\hline 44 & 0.18 & 0.17 & 0.17 & 0.25 & 0.77 \\
\hline 45 & 0.15 & 0.15 & 0.14 & 0.16 & 0.61 \\
\hline 46 & 0.16 & 0.15 & 0.14 & 0.17 & 0.62 \\
\hline 51 & 0.17 & 0.18 & 0.14 & 0.18 & 0.67 \\
\hline 62 & 0.15 & 0.14 & 0.14 & 0.16 & 0.59 \\
\hline 70 & 0.17 & 0.15 & 0.15 & 0.18 & 0.65 \\
\hline 71 & 0.13 & 0.15 & $-c$ & 0.19 & $0.63^{d}$ \\
\hline 72 & 0.19 & 0.18 & 0.17 & 0.20 & 0.74 \\
\hline 73 & - & 0.16 & 0.16 & 0.18 & $0.67^{d}$ \\
\hline 74 & 0.15 & 0.15 & 0.14 & 0.17 & 0.61 \\
\hline 75 & 0.14 & 0.13 & 0.12 & 0.15 & 0.53 \\
\hline 76 & 0.12 & 0.12 & 0.13 & 0.18 & 0.55 \\
\hline 77 & - & - & $-c$ & 0.17 & $0.68^{d}$ \\
\hline Mean & 0.16 & 0.16 & 0.15 & $0.18(0.20)^{e}$ & $0.66(0.68)^{\theta}$ \\
\hline Mean (mrem) & 16 & 16 & 15 & $18(20)^{e}$ & $66(68)^{e}$ \\
\hline SDM (\%) & 9 & 10 & 9 & $11(65)^{e}$ & $8(21)^{e}$ \\
\hline
\end{tabular}

aSee Fig. 4-21 for sampling locations. bOutlier.

cNo data available; dosimeter was missing.
'Calculated as four times the average quarterly dose, as determined from available data.

eData with outlier included.

4-46 SNL/CA Site Environmental Report for 1992 


\section{5 - Environmental Impacts}

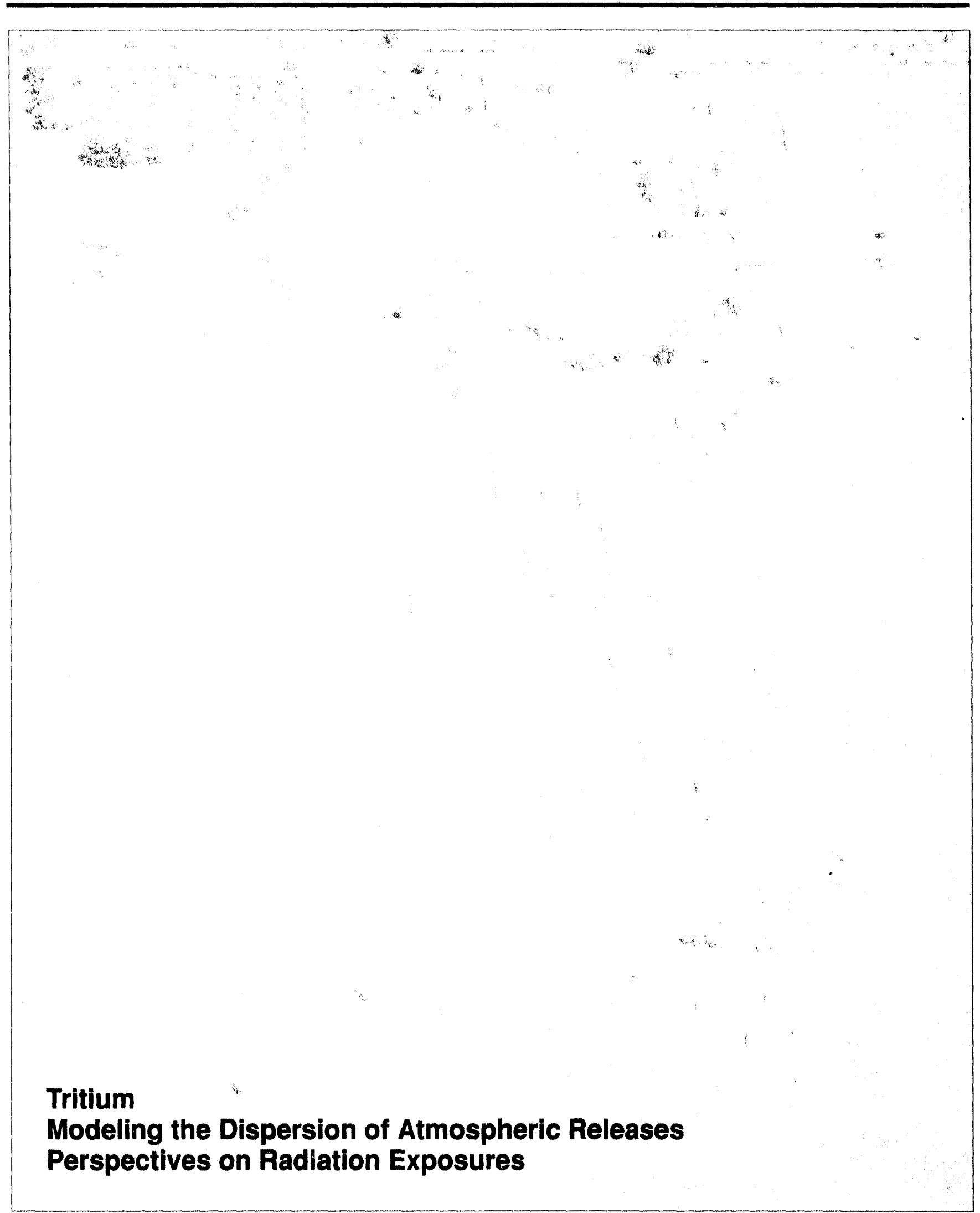




\section{Environmental Impacts}

Operations at SNL/California have resulted in the release of low levels of radionuclides to the surrounding environment. The public could be exposed to extremely low levels of radiation from these releases (uranium, which was used on-site in previous years, and tritium, which is being phased out).

At the end of each calendar year, the impacts from site emissions are assessed and documented in this report. The radiological impacts are determined by calculating the radiation dose to a maximally exposed individual and for the total population living within $80 \mathrm{~km}$ (50 miles) of the site.

All the significant exposure pathways are sampled as a part of SNL/California's Environmental Monitoring Program. However, most of the pollutants released are at very low concentrations once dispersed in the environment. As a result, levels often are too low to determine dose to humans directly from environmental measurements. Furthermore, the origin or source of tritnum (the only radionuclide released from SNL/California) found in the environment is difficult to trace. It may be released from SNL/California operations, LLNL operations, world-wide fallout, or nature. Consequently, the public's exposure to tritium directly resulting from $\mathrm{SNL} /$ California releases is difficult to measure. Therefore, potential radiation doses are calculated based on facility emissions, i.e., stack monitoring data. This information is entered into EPA-approved environmental transport and exposure pathway computer models to calculate off-site doses. In this report, the effective dose equivalent is used to express radiation dose in terms of potential health risk.
Appendix $C$ explains radiation dose terminology and the methods and assumptions used in calculating these doses.

The major pathways of radiation exposure from atmospheric releases are inhalation and consumption of locally grown foods. Tritium accounts for any such dose from SNL/California.

\section{TRITIUM}

Because tritium is the only radionuclide discharged to the environment in measurable amounts from operations conducted at SNL/California, much of the monitoring program is devoted to assessing and controlling its impact. For this reason, some specific information about the dosimetry and environmental behavior of tritium is provided.

Tritium $\left({ }^{3} \mathrm{H}\right.$, commonly designated by $\mathrm{T})$, a radioactive isotope of hydrogen, is a naturally occurring and ubiquitous component of the environment. Tritium is produced in relatively large amounts by interactions of cosmic rays and gases of the upper atmosphere. The world-wide inventory of tritium has been substantially increased by nuclear weapons testing. Tritium has a physical half-life of 12.3 years and decays by emission of a beta particle of very low energy (maximum energy $18 \mathrm{keV}$ and an average energy of $5.7 \mathrm{keV}$ ).

At room temperature, tritium combines with gaseous hydrogen $\left(\mathrm{H}_{2}\right)$ to form $\mathrm{HT}$. Even more readily, it exchanges with one hydrogen in water vapor to form "tritiated water" (HTO), the most common form of tritium in the environment. Tritiated water is easily absorbed into living organisms, behaving like normal water. For this reason, tritium occurs naturally in all living things.

SNL/CA Site Environmental Report for 1992 
Tritium is generally considered one of the least toxic of all radioisotopes. Because of the extremely low energy of the beta particle emission, tritium does not pose an external radiation hazard. (The mean range of tritium's beta particle in water is $0.69 \mu \mathrm{m}$.) However, tritium taken into the body can cause harm at a cellular level.

Tritium released to the atmosphere can exist in two chemical forms: tritium oxide (i.e., water vapor-HTO or $\mathrm{T}_{2} \mathrm{O}$ ) or elemental tritium (gas-HT or $\mathrm{T}_{2}$ ). Human absorption and metabolism differ greatly for the two chemical forms of tritium. These two forms also behave differently in the environment.

Tritium oxide is readily absorbed by the body when inhaled or ingested with food or water. Tritium oxide may also be absorbed through the skin. An individual exposed to airborne tritium oxide typically absorbs about half as much tritium through the skin as by inhalation. In this report, all tritium doses from the air pathway have been calculated taking into account both inhalation and skin absorption. In addition, the dosimetry models used for tritium oxide assume that the body would eliminate tritium at the same rate as water.

Elemental tritium is not assimilated by the human body. Of the tritium gas inhaled, only about $0.004 \%$ is converted to the oxide form and retained in the body as free water. For this reason, the oxide form of tritium is about 25,000 times more harmful (higher dose) than an equal dose of elemental tritium.

Careful perusal of the environmental monitoring data indicates that the only evidence of impact due to SNL/California (and LLNL) operations is a slight increase in tritium concentrations. Tritium concentrations in air, rainwater, vegetation, and wine are slightly greater in the vicinity of SNL/California and LLNL than at more distant locations. The tritium concentrations in air have decreased over the past several years, following the trend of decreased tritium effluents released to the air. Because the air pathway is the primary source of tritium for the other environmental media, concentrations of tritium in these environmental media are expected also to trend downward over the next few years. The levels of tritium detected are not high enough to be a health concern. The analytical methods used are sensitive enough to allow SNL/California to detect even these very small amounts of radioactive materials in the environment.

\section{Modeling the Dispersion OF Atmospheric Releases}

Radioactive materials discharged to the atmosphere are mixed and dispersed as they are transported by prevailing winds. This can result in internal exposure to people via inhalation and ingestion. Radionuclides are removed from air by radioactive decay and deposition onto the ground or vegetation. The deposited radionuclides can then move through various pathways to humans. Additional information on environmental transport processes can be found in Appendix C.

Computer models developed by the EPA simulate the movement, decay, and deposition of radionuclides to predict the air concentrations at downwind locations. These models also calculate the uptake and transfer of radionuclides through the food- 


\section{Environmental Impacts}

chain. This information can be used to estimate radiation doses to individuals residing in specific areas.

The radiological impacts of SNL/California operations are assessed by determining four potential doses to the public:

- external (direct) dose at the site boundary,

- maximally exposed individual dose (all pathways),

- air pathway dose, and

- collective (population) dose.

Figure 5-1 is a simplified representation of the important exposure pathways.

\section{External Radiation Dose}

The external dose is a measure of the radiation field at the site boundary from direct penetrating sources of radiation (primary gamma rays). Thermoluminescent dosimeters (TLDs) are used to measure the external dose at locations around the SNL/California site that permit uncontrolled public access (e.g., fence lines and open areas). Dosimeters also are placed at distant locations to serve as background or control measurements. The near-field and far-field dosimeters can be compared to determine if site operations contribute to the external dose rate. That is, the difference in the dose rates between the site perimeter and the background locations

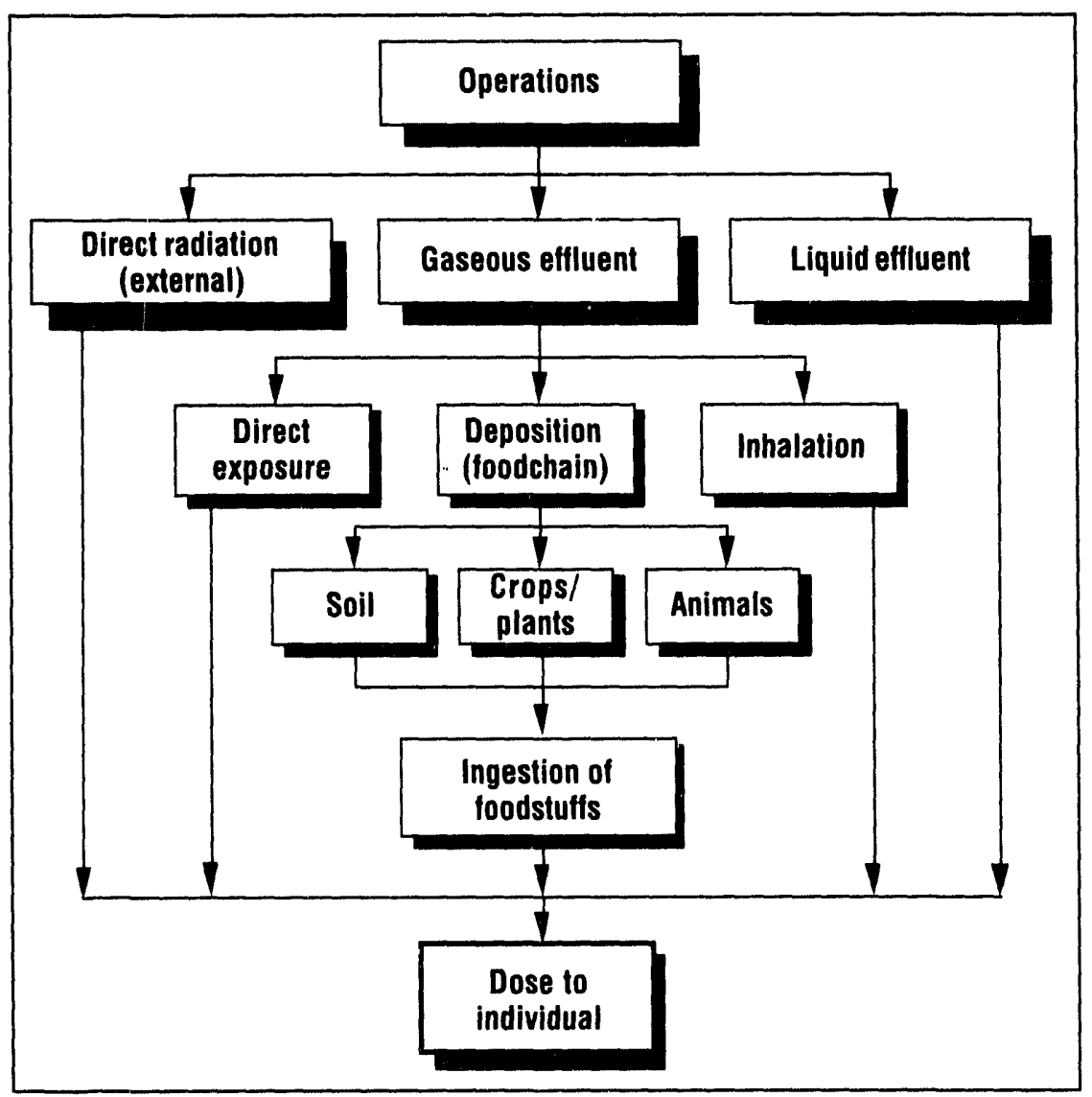

Figure 5-1. Major radiation exposure pathways. 


\section{Environmental Impacts}

represents the external dose due to

SNL/California operations.

In 1992, the annual average external dose at the site boundary was $62 \mathrm{mrem}$ $(0.62 \mathrm{mSv})$, compared to $66 \mathrm{mrem}$ $(0.66 \mathrm{mSv})$ for the Livermore Valley monitoring stations. These results are virtually identical within the statistical confidence level of the method, indicating that no external dose was measured as a direct result of SNL/California operations in 1992. See page 4-23 for a more detailed discussion of the methodology and results.

\section{Maximally Exposed Individual Dose}

The maximally exposed individual is a hypothetical person who lives at an off-site location and has a presumed lifestyle that produces the highest credible radiation dose. The follcwing exposure pathways were included in the calculated dose potentially received by this maximally exposed individual in 1992:

- inhalation of air downwind,

\section{Maximally Exposed Individual}

The concept of a maximally exposed individual" is used when radiation doses to the public are calculated. This is a hypothetical person who lives at a location where the highest radiation dose would be received. The following assumptions are made:

- The person resides off-site where the highest calculated air concentration occurs

- The person continuously occupies the residence (24 hrs./day for 365 days/yr.)

- A portion of the person's food (meat, milk, vegetables) and water are locally grown or produced.

Appendix C provides more details.
- submersion in the airborne plume, and

- consumption of food and water contaminated by fallout.

The characteristics and assumptions used to calculate this individual's dose were selected to maximize the contributions of all realistic environmental pathways of exposure to radionuclides. In reality, these assumptions overestimate the dose (because no one actually lives under the presumed conditions). Thus, this is not an actual dose received by anyone, but an upper-limit estimate.

The dose to the maximally exposed individual from SNL/California operations in 1992 was $0.02 \mathrm{mrem}\left(2 \times 10^{-4} \mathrm{mSv}\right)$ effective dose equivalent (see Tables 5-1 and 5-2). This dose represents the total exposure from all emission sources and all exposure pathways (i.e., inhalation, air submersion, and ingestion).

The current DOE radiation protection limit for the public is $100 \mathrm{mrem} / \mathrm{yr}$. $(1 \mathrm{mSv} / \mathrm{yr}$.), which is consistent with the recommendations of the International Commission on Radiological Protection (ICRP). Thus, the maximum calculated dose was $0.02 \%$ of the allowable standard.

\section{Air Pathway Dose (Clean Air Act Standards)}

The EPA has established radiation dose limits for protection of the public in Title 40 CFR, Part 61, Subpart H, of the Clean Air Act. Under the National Emissions Standards for Hazardous Air Pollutants (NESHAPs) Radionuclide Rule, no member of the public shall receive a radiation dose of more then $10 \mathrm{mrem} / \mathrm{yr}$. from emissions to the atmosphere. To demonstrate compli- 


\section{Environmental Impacts}

ance with the Clean Air Act,

SNL/California must calculate the air pathway dose using the Clean Air Act

Assessment Package, 1988 (CAP88) com-

puter codes. This software contains expo-

sure characteristics and dose factors speci-

fied by the EPA.

Because only the air pathway contributes to off-site doses at SNL/California, this dose is the same as the maximally exposed individual dose. Therefore, the 1992 air pathway dose was 0.02 mrem, which is $0.2 \%$ of the EPA Clean Air Act limit.

\section{Population Dose}

The regional population dose from SNL/California operations was estimated by calculating the radiation dose to the total population residing within an $80-\mathrm{km}$ (50-mile) radius of the SNL/California site. Exposure to regional populations can include the following pathways: inhalation, air submersion, and ingestion. The population dose is referred to as the collective effective dose equivalent. It is expressed in units of person-rem or person-Sv.

The collective dose for 1992 was 0.9 person-rem (0.009 person-Sv). There are no regulatory limits for collective dose. DOE Order 5400.5 requires an estimate of the collective dose as an additional evaluation of public impact of site operations. This population dose is $5 \times 10^{-5 \%}$ of the estimated $1.9 \times 10^{6}$ person-rem collective effective dose equivalent from natural background radiation (assuming $300 \mathrm{mrem} / \mathrm{yr}$. as a conservative average dose). ${ }^{3}$

\section{Perspectives on Radiation EXPOSURES}

This section provides basic information about the sources of radiation exposure and compares various levels of radiation doses. Thus, it is intended to more clearly explain the radiation doses resulting from SNL/California operations.

People are continually exposed to background radiation from a variety of sources. These background sources include naturally radioactive materials in the earth and cosmic radiation from the sun. Recent evidence suggests that as much as two-thirds of a person's background dose comes from naturally occurring radon gas, which accumulates in buildings. Radioactive materials also are in the environment as a result of former nuclear weapons testing.

The amount of background radiation a person receives depends on his or her location and lifestyle. In the Livermore area, background radiation is approximately 200-300 mrem/yr.

In addition to natural background radiation, the average person in the U.S. receives approximately $65 \mathrm{mrem} / \mathrm{yr}$. from medical procedures (e.g., x-rays) and radioactive materials in consumer products.

The national average radiation dose received by the general public from natural and other man-made sources is approximately 365 mrem/yr. (see Fig. 5-2). Supplemental information about the radiation sources is provided below. The calculated maximum dose from SNL/California operations in 1992 was 0.02 mrem. This dose is extremely small compared to Federal standards and natural background levels of radiation. 


\section{Environmental Impacts}

Figure 5-2.

Sources of radia-

tion received by $a$

U.S. resident.

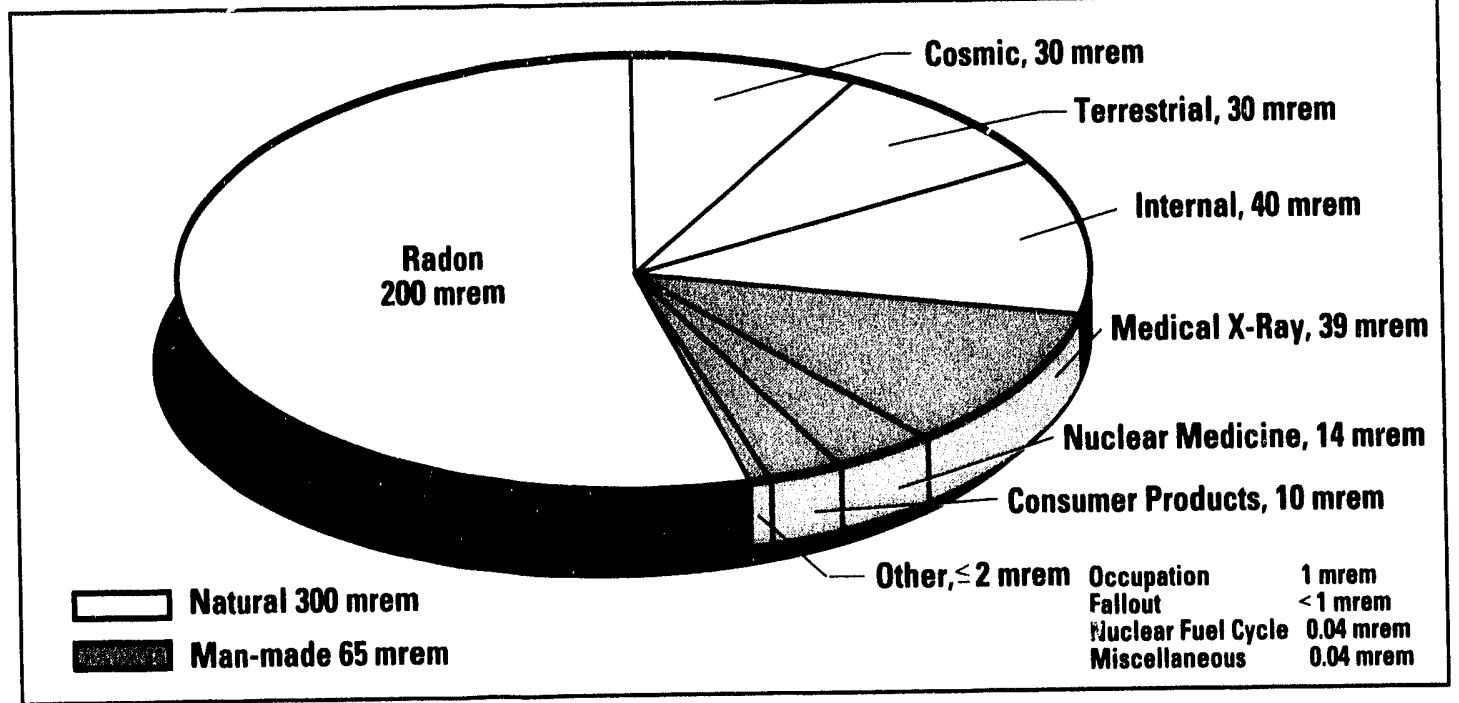

\section{Natural Background Radiation}

The major source of radiation expcsure to the public is attributed to radiation from naturally occurring radioactive materials in the environment. This exposure occurs from both external and internal sources. This radiation often is referred to as natural background radiation. The amount of radiation exposure an individual receives varies according to location and lifestyle.

\section{Cosmic Radiation}

Energetically charged particles from space continuously enter the Earth's atmosphere. These particles, along with secondary particles and photons they create, are referred to as cosmic radiation. Because the atmosphere provides a shielding effect, the intensity of this radiation increases with altitude above sea level. The average annual dose to people in the U.S. from cosmic radiation is about 27 mrem (NCRP, 1987a). ${ }^{29}$ Due to the higher elevation, people living in the Rocky Mountain states receive an annual cosmic radiation dose of 60-80 mrem.

\section{Terrestrial Radiation}

Terrestrial radiation refers to radiation emitted from radioactive materials, primarily potassium $\left({ }^{40} \mathrm{~K}\right)$, isotopes of thorium (Th), and isotopes of uranium (U), in the Earth's rocks and soils. The average annual dose from terrestrial gamma radiation is about 28 mrem, but varies geographically across the U.S. (NCRP, 1987a). ${ }^{29}$ For example, this dose has been measured to be about 63 mrem on the eastern slopes of the Rocky Mountains.

\section{Internal Radiation}

Natural radionuclides in the environment enter the body by inhalation and by ingestion of foods, milk, and water. These radionuclides are metabolized in the body similarly to nonradioactive elements, although each element is metabolized differently. Natural radionuclides include isotopes of uranium, thorium, radium, radon, poloni$\mathrm{um}$, bismuth, and lead from the $238 \mathrm{U}$ and 232Th decay series. In addition, the body contains isotopes of potassium $\left({ }^{40} \mathrm{~K}\right)$, rubidium $\left({ }^{87} \mathrm{Rb}\right)$, and carbon $\left({ }^{14} \mathrm{C}\right)$. 
The major contributors to the annual dose equivalent for internal radionuclides are the short-lived decay products of radon (mostly ${ }^{222} \mathrm{Rn}$ ), which accounts for an average dose of about $200 \mathrm{mrem} / \mathrm{yr}$. in the United States. Radon gas, a decay product of the uranium series, accumulates in buildings. Radon levels vary widely according to geographical area.

The average dose from other internal radionuclides is about $39 \mathrm{mrem} / \mathrm{yr}$, which is predominantly attributed to the naturally occurring radioactive isotope of potassium, ${ }^{40} \mathrm{~K}$. A small fraction of all potassium is ${ }^{40} \mathrm{~K}$. Thus, any food containing potassium also contains small amounts of ${ }^{40} \mathrm{~K}$. The concentration of ${ }^{40} \mathrm{~K}$ in human tissues is similar in all parts of the world (NCRP, 1987a). ${ }^{29}$

\section{Man-made Sources of Radiation}

In addition to natural sources, most people are exposed to a number of man-made sources of radiation. These generally fall into the categories of consumer products, medical sources, and other minor sources.

Many consumer products contain radioactive materials. For some products, like smoke detectors, the ionizing radiation is required for the functioning of the device. Other products, such as televisions, give off radiation as an incidental by-product. Table 5-3 gives examples of common consumer products containing radioactive materials. The U.S. average annual individual dose from consumer products is about 10 mrem (NCRP, 1987a). ${ }^{29}$

Radiation is an important tool of diagnostic medicine and cancer treatment. In general, medical exposures from diagnostic or therapeutic $x$-rays result from radiation beams directed to specific areas of the body.
Thus, all body organs normally are not irradiated uniformly.

Nuclear medical examinations may also involve the internal administration of radioactive materials or radionuclides to the patient. The average annual effective dose equivalent for the U.S. population from medical examinations is $53 \mathrm{mrem}$ (about 39 mrem for diagnostic $x$-rays and $14 \mathrm{mrem}$ for nuclear medical procedures) (NCRP, 1989). 30 The actual dose an individual receives depends on the number and type of treatments received each year (NCRP, 1989). ${ }^{30}$

A few other sources of radiation contribute minor doses to people in the United States. The dose to the general public from the nuclear fuel cycle-such as uranium mines, mills, fuel processing plants, nuclear power plants, and transportation-has been estimated at less than $1 \mathrm{mrem} / \mathrm{yr}$. (NCRP, 1987a). ${ }^{29}$

Small doses to individuals occur as a result of radioactive fallout from atmospheric nuclear weapons tests, which were conducted before the 1960s; emissions of radioactive materials from other nuclear facilities, such as DOE facilities; and transportation of radioactive materials. The combined dose from these sources contributes less than $1 \mathrm{mrem} / \mathrm{yr}$. to the average individual in the U.S. (NCRP, 1987a). ${ }^{29}$

Table 5-4 lists examples of radiation doses from a variety of sources. This table presents a range of radiation doses to help add perspective to the doses discussed in this report. 


\section{Environmental Impacts}

\section{Table 5-1. Dose Summaries.}

\begin{tabular}{|c|c|c|c|}
\hline Pathway & $\begin{array}{c}\text { Dose } \\
\text { (mrem/yr) }\end{array}$ & Organ & $\begin{array}{c}\text { Dose } \\
\text { (mrem/yr) }\end{array}$ \\
\hline Internal Dose & $1.7 \times 10^{-2}$ & Gonads & $1.7 \times 10^{-2}$ \\
\hline Ingestion & $9.4 \times 10^{-4}$ & Breast & $1.7 \times 10^{-2}$ \\
\hline Inhalation & $1.6 \times 10^{-2}=$ & Bone marrow & $1.7 \times 10^{-2}$ \\
\hline External & 0 & Lungs & $1.7 \times 10^{-2}$ \\
\hline \multirow[t]{3}{*}{ Air Immersion } & 0 & Thyroid & $1.7 \times 10^{-2}$ \\
\hline & & Bone surface & $1.7 \times 10^{-2}$ \\
\hline & & Remainder & $1.7 \times 10^{-2}$ \\
\hline Total EDE & $1.7 \times 10^{-2}$ & Total EDE & $1.7 \times 10^{-2}$ \\
\hline
\end{tabular}

\section{Table 5-2. Effective Dose Equivalent and Individual Lifetime}

Risk for Critical Receptors.

\begin{tabular}{lccc}
\hline \multicolumn{1}{c}{ Direction } & $\begin{array}{c}\text { Distance } \\
(\mathbf{m})\end{array}$ & $\begin{array}{c}\text { EDEa }^{\mathrm{a}} \\
(\mathbf{m r e m} / \mathbf{y})\end{array}$ & Risk $^{\text {b }}$ \\
\hline NE & 1100 & $1.7 \times 10^{-2}$ & $5.0 \times 10^{-7}$ \\
SE & 800 & $2.2 \times 10^{-3}$ & $6.1 \times 10^{-8}$ \\
SW & 900 & $3.3 \times 10^{-3}$ & $1.9 \times 10^{-7}$ \\
W & 1200 & $8.5 \times 10^{-3}$ & $2.3 \times 10^{-7}$ \\
\hline
\end{tabular}

a/ndividual effective dose equivalent for all pathways.

bepresents individual lifetime risk. The risk to the maximally exposed individual $\left(5.0 \times 10^{-7}\right)$ indicates a

probability of 1 chance in $2,000,000$ of contracting a fatal cancer.

clndicates location of maximally exposed individual (highest off-site radiologcal dose). 


\section{Environmental Impacts}

\section{Table 5-3. Examples of Consumer Products Containing}

Radionuclides.

\begin{tabular}{llc}
\hline \multicolumn{1}{c}{ Product } & \multicolumn{1}{c}{ Radionuclide } & Activity \\
\hline Timepieces* & ${ }^{3} \mathrm{H}$ & $5-25 \mathrm{mCi}$ \\
Aircraft Instruments* & ${ }^{3} \mathrm{H}$ & $\leq 10 \mathrm{Ci}$ \\
& ${ }^{147} \mathrm{Pm}$ & $\leq 0.3 \mathrm{Ci}$ \\
& ${ }^{226} \mathrm{Ra}$ & $\leq 20 \mu \mathrm{Ci}$ \\
Marine Compasses* & ${ }^{3} \mathrm{H}$ & $0.2-2 \mathrm{Ci}$ \\
Exit Signs* & ${ }^{3} \mathrm{H}$ & $2-15 \mathrm{Ci}$ \\
Voltage Discharge Tubes & ${ }^{147} \mathrm{Pm}$ & $3 \mu \mathrm{Ci}$ \\
VacuumTubes & Natural thorium & $0.8-1.2 \%$ \\
Low Voltage Fuses & ${ }^{147} \mathrm{Pm}$ & $3 \mu \mathrm{Ci}$ \\
Smoke Detectors & ${ }^{241} \mathrm{Am}$ & $0.1 \mathrm{mCi}$ \\
& ${ }^{226} \mathrm{Ra}$ & $0.01-15 \mu \mathrm{Ci}$ \\
& Natural uranium & $7.5 \mathrm{mg}$ \\
\hline
\end{tabular}

*The radioactive material is used for illumination.

\section{Table 5-4. Comparison of Various Radiation Doses.}

\begin{tabular}{|c|c|}
\hline Dose Level (mrem) & Source/Description \\
\hline 0.02 & $\begin{array}{l}\text { Dose to maximally exposed individual from SNL/CA operations in } \\
1992 .\end{array}$ \\
\hline 1 & Average daily radiation dose received by a U.S. resident. \\
\hline 5 & $\begin{array}{l}\text { Cosmic radiation dose to a person on a round-trip airplane flight frorn } \\
\text { New York to Los Angeles. }\end{array}$ \\
\hline 10 & Typical dose from one chest $x$-ray, using modern equipment. \\
\hline 10 & $\begin{array}{l}\text { Annual dose limit, set by the EPA under the Clean Air Act, for } \\
\text { exposures from airborne emissions from operations of nuclear fuel } \\
\text { facilities, including power plants, uranium mines, and DOE facilities. }\end{array}$ \\
\hline 33 & $\begin{array}{l}\text { Average yearly dose from cosmic radiation to people in the Livermore: } \\
\text { area. }\end{array}$ \\
\hline 66 & $\begin{array}{l}\text { Average yearly dose to people in the United States from man-made } \\
\text { sources of radiation. }\end{array}$ \\
\hline $60-80$ & $\begin{array}{l}\text { Average yearly dose from cosmic radiation to people in the Rocky } \\
\text { Mountain states. }\end{array}$ \\
\hline 100 & $\begin{array}{l}\text { Annual limit of radiation dose from DOE facilities to a member of the } \\
\text { public (all sources and all pathways). }\end{array}$ \\
\hline 170 & $\begin{array}{l}\text { Average yearly dose to an airline flight crew member from cosmic } \\
\text { radiation. }\end{array}$ \\
\hline 300 & $\begin{array}{l}\text { Average yearly dose received by people in the United States from all } \\
\text { sources of natural background radiation. }\end{array}$ \\
\hline 900 & Average dose from a lower-intestinal medical diagnostic $x$-ray series. \\
\hline $1000-5000$ & EPA Protective Action Guidelines for nuclear accidents. \\
\hline 5000 & $\begin{array}{l}\text { The BEIR } V \text { report estimated that an acute dose at this level would } \\
\text { result in a lifetime excess risk of death from cancer of } 0.8 \text { percent. }\end{array}$ \\
\hline $50,000-100,000$ & $\begin{array}{l}\text { Radiation doses in this range are likely to result in varying degrees of } \\
\text { radiation sickness (complete recovery expected). }\end{array}$ \\
\hline $500,000-600,000$ & Radiation doses in this range would most likely result in death. \\
\hline
\end{tabular}




\section{6 - Environmental Program}

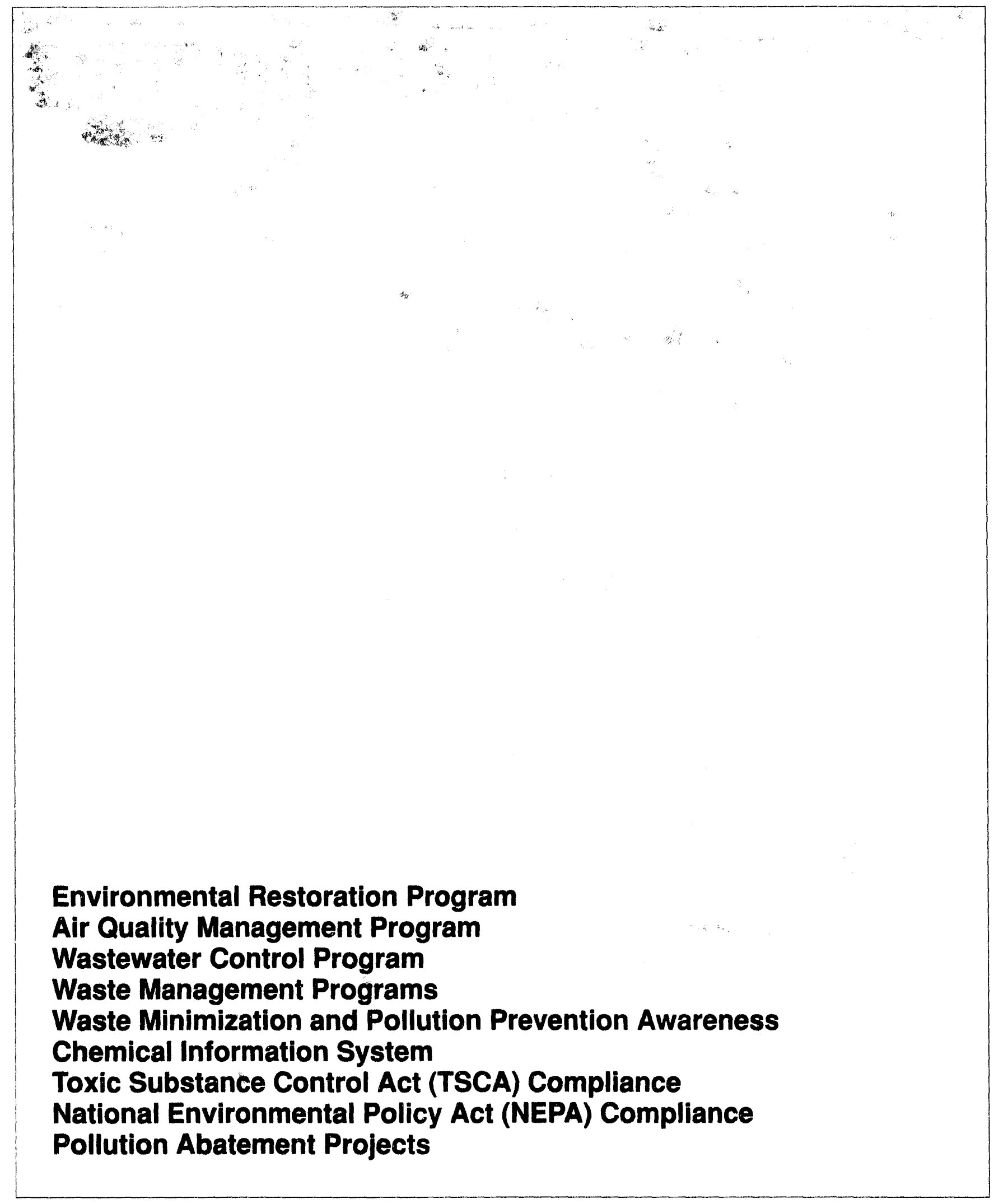




\section{Environmental Program Information}

It is DOE and SNL policy to conduct operations in an environmentally responsible manner and in compliance with applicable environmental standards. SNL/California maintains a variety of programs to implement these laws and regulations.

This chapter describes programs within SNL/California's Environmental Protection Department to comply with these environmental requirements. It summarizes activities performed in 1992 to manage hazardous waste, restore contaminated inactive waste sites, control emissions to the environment, and conduct special assessments.

\section{Environmental Restoration Program}

The Comprehensive Environmental Response, Compensation, and Liability Act (CERCLA) and Superfund Amendments and Reauthorization Act (SARA) mandate cleanup of toxic and hazardous contaminants at closed or inactive waste sites. The CERCLA/SARA-related activities at SNL/California are being addressed under the DOE's Environmental Restoration Program and directed by the State RWQCB.

Currently, SNL/California is remediating two sites (Fig. 6-1): the Fuel Oil Spill and the Navy Landfill. A third previously listed site, the Trudell Auto Repair Shop, was cleaned up and officially closed in 1990. No new activities were carried out at this site in 1992. In addition, an investigation continued at five sites with suspected contamination. Cleanup activities at $\mathrm{SNL} /$ California are directed by the RWQCB Site Cleanup Order 88-142, ${ }^{9}$ issued in September of 1988. This Order was modified in 1989 for the Fuel Oil Spill (Order 89-
184)..$^{10}$ These sites and activities conducted by the Environmental Restoration Program are described below.

\section{Fuel Oil Spill}

In 1975, as the result of an accidental puncture of an underground transfer line, 59,500 gallons of \#2 diesel fuel were released into the vadose zone from an above-ground reserve fuel tank. The groundwater has been monitored in this area since 1985 and shows occasional low-level contamination of fuel oil components. This aquifer is not used as a source of drinking water.

SNL/California completed a remedial investigation of the spill site in November 1988. In 1990, SNL/California, Argonne National Laboratory, and Notre Dame University performed several bench-scale tests to determine the most effective means of cleanup. The resulting treatability report indicated that bioremediation is the most effective of the technologies tested in reducing fuel oil contamination. In 1991, in-situ bioremediation tests were done.

Bioremediation was proven indeed to be effective, but it proceeds at a slower rate than the laboratory tests, which were done in slurry reactors.

In December 1990, Argonne National Laboratory began groundwater flow and contaminant transport modeling to support the pilot bioremediation system design. In 1991, Los Alamos National Laboratory (LANL) performed model validation and verification of the one-, two-, and threedimensional models by concurrently modeling data from the bench-scale and field tests.

Additional bench-scale studies are being conducted to establish nutrient and oxygen levels, and to identify degradation prod-

SNL/CA Site Environmental Report for 1992 


\section{Environmental Program Information}

Figure 6-1. SNL/California remediation sites.

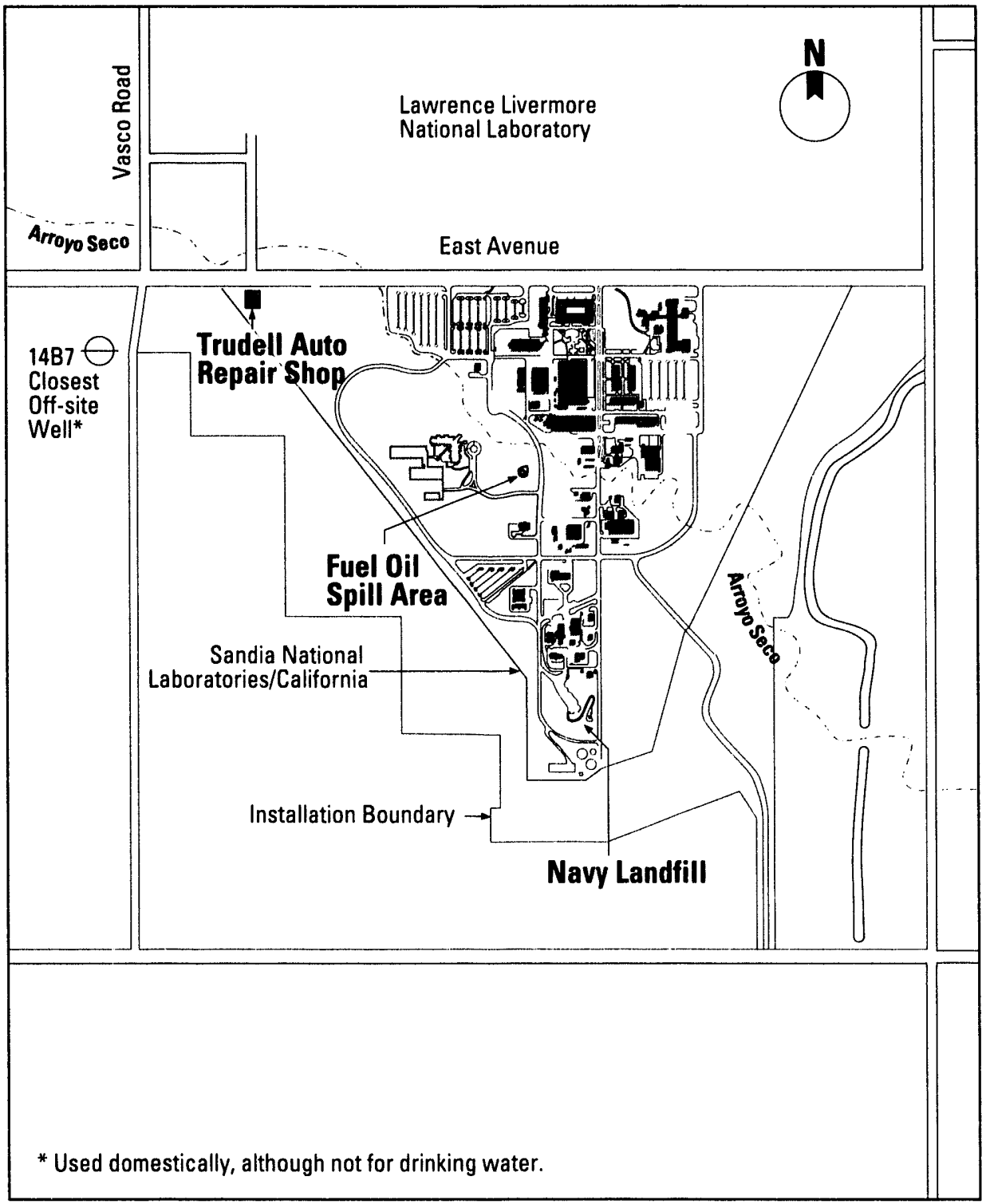

ucts. Three wells downgradient of the spill site have been completed. A bore-hole seismic/electromagnetic field study has been initiated to help evaluate the distribution of the diesel in the subsurface. A soil characterization study will determine appropriate background levels of inorganic ions and elements in the soil. A new baseline risk assessment, following the current EPA guidelines, was begun late in 1992.

\section{Navy Landfill}

There is an inactive landfill located at the southern end of the SNL/California site that was used by the Navy during and shortly after World War II, and again by 


\section{Environmental Program Information}

LLNL in the 1950s and early '60s. A survey of historical records and landfill contents indicated that only general construction debris and machine turnings were disposed of at the site. There is no indication of any hazardous materials being buried at this landfill. The landfill measures approximately $11,300 \mathrm{~m}^{2}$ in area and $68,800 \mathrm{~m}^{3}$ in volume.

The landfill appeared on the State of California's Solid Waste Water Quality Assessment Test (SWAT) Program list in December 1987. Consequently, the State required a SWAT Proposal (equivalent to a Remedial Investigation Plan).

$\mathrm{SNL} /$ California submitted the proposal in March 1989.11 A SWAT Report was submitted to the RWQCB in 1990.31

$\mathrm{SNL} /$ California is awaiting comments from the State on this report. The RWQCB expects to complete the review and request changes, additional sampling, or additional information early in 1993.

To provide site characterization, an upgradient well, three downgradient wells, a piezometer, and two lysimeters have been installed. The wells and the lysimeters are sampled quarterly.

\section{Trudell Auto Repair Site}

The cleanup of the Trudell Auto Repair site was completed, and officially closed by the RWQCB in 1990 . This property was purchased by DOE in 1987 to expand SNL/California's security buffer zone. At the time of purchase, the land surrounding the shop was contaminated with oil, lead, and low levels of chlorinated solvents resulting from improper disposal procedures. The contamination at the site was not due to DOE or SNL/California activities.
Results of a stage II field investigation were submitted in March 1989. This included soil sampling to verify the extent of pollution and provided data for a cost/feasibility study. A Remedial Investigation Plan was submitted in September 1989,32 as required by the 1988 RWQCB Cleanup Order.

In September 1989, the buildings and garage parking slabs were removed from the Trudell site. The Environmental Restoration Program developed a sampling plan to characterize possible localized high concentrations of lead (hot spots). ${ }^{33}$

With approval from the RWQCB, $\mathrm{SNL} /$ California proceeded with the cleanup under an Interim Remedial Measure (IRM). This continued through August 1990. Fifty-eight truckloads of soil, approximately $20 \mathrm{yd}^{3}{ }^{3}$ each, were shipped to a RCRA-permitted landfill for disposal. An underground storage tank was also removed. The excavations were filled with clean soil and restored to the same condition as the surrounding area. A feasibility study was submitted in September 1990. The RWQCB officially closed the site in December 1990. As part of post-closure surveillance, SNL/California continues to monitor the groundwater beneath the site.

One well (MW-406) was installed by LLNL at the site. This well was installed to monitor the spread of the LLNL TCE plume along the Arroyo Seco. The TCE plume is tricholoroethane in the groundwater, as a result of site activities in the 1950s and '60s (when it was owned by the Navy). When the RWQCB approved the Trudell site closure, it directed SNL/California to monitor this well to identify any remaining contamination from the repair shop activities. No contamination related to these activities has been noted.

SNL/CA Site Environmental Report for 1992 


\section{Environmental Program Information}

\section{Miscellaneous Sites}

In 1988, the DOE performed an environmental survey of the SNL/California site. This survey identified five potentially contaminated areas. In 1991, the soil from these areas was sampled and analyzed. The results of the analyses showed no contamination above RCRA action levels. A report on the sampling and analyses was sent to the RWQCB in 1992.12 No official response has yet been received.

\section{Underground Storage Tank (UST) Management}

SNL/California complies with Federal and State requirements for USTs. 34

SNL/California has only one regulated UST, which is located in a vault behind Bldg. 964. This 1,000-gallon tank was installed in 1986 and is used to store diesel fuel for $\in$ mergency power generators. It is constructed of double-walled fiberglass and is equipped with a Leak Alert ${ }^{\mathrm{TM}}$ system (Universal Sensors \& Devices), which meets all tank monitoring requirements. ${ }^{34}$ The Leak Alert ${ }^{\mathrm{TM}}$ system has two sensors placed between the primary and secondary walls of the tank. The first is a thermal element that detects the presence of liquid. The second is a metal-oxide semiconductor that detects organic vapors. These sensors are connected to a signal panel, which emits both audio and visual alarms.

\section{Spill Prevention Control and Countermeasure (SPCC) Plan}

The Spill Prevention Control and Countermeasure (SPCC) Plan establishes procedures for controlling, and if necessary, remediating oil spills at SNL/California. 35
The plan was prepared in accordance with Title 40 CFR, Part 112.36 It was approved in December 1992.

\section{Air Quality Management Program}

In 1992, SNL/California continued activities that were initiated to assure site-wide compliance with air quality regulations. These activities are directed toward assuring adequate evaluation of air permit requirements and other applicable regulations. Operations at SNL/California are subject to the rules and regulations of the BAAQMD, ARB, and EPA, which have jurisdiction over facilities that emit air contaminants.

The Air Quality Management Program identifies and evaluates potential sources of air pollutants, and documents compliance requirements. It has been involved in conducting a site-wide air emissions source inventory, covering all operations that could emit air contaminants. The baseline inventory was completed in 1992. It provides data on materials, equipment, and operations that are subject to air quality regulations. Applications for air permits or exemption requests have been prepared as needed in conjunction with this inventory. SNL/California operates 35 permitted sources and 37 exempt sources. SNL/California also is implementing an Employer Trip Reduction Program to help reduce air pollution.

\section{Air Quality in the Bay Area}

Air quality in the San Francisco Bay Area has been improving in recent years. Record progress was made in 1992 on all three of the criteria contaminants that have been 


\section{Environmental Program Information}

problems in the past decade. Before 1992, the Bay Area was considered a nonattainment area for ozone, carbon monoxide, and fine particulate matter $\left(\mathrm{PM}_{10}\right)$ air quality standards. For the first time in three decades, no State or national standard for carbon monoxide was exceeded. The State annual particulate standard was met for the first time at all $\mathrm{PM}_{10}$ monitoring stations. On two days, the national ozone standard was exceeded, again tying record lows obtained in 1990 and 1991 . The exceedance days were distributed so that no station averaged one day or more over this threeyear period, thus meeting for the first time this national criterion for ozone attainment. (Attainment is reached when the standards are not exceeded on more than one day per year.)

As noted above, the eight-hour national and State standard for carbon monoxide (9 ppm) was attained for the first time in over thirty years. The highest district eighthour average for the year was $7.5 \mathrm{ppm}$. About $78 \%$ of the Bay Area's carbon monoxide comcs from motor vehicles. Compared to other industrial emissions, carbon monoxide emissions from all permitted sources at SNL/California is insignificant.

Respirable particulate $\left(\mathrm{PM}_{10}\right)$ levels decreased dramatically in 1992, reflecting exceptionally good ventilation this year. The State annual geometric mean standard of $30 \mu \mathrm{g} / \mathrm{m}^{3}$ has been difficult to meet. In 1992, for the first time, all $\mathrm{PM}_{10}$ stations met this standard. All monitoring stations had fewer days exceeding the State 24-hr. average $50 \mathrm{\mu g} / \mathrm{m}^{3}$ standard, and all days were more than $20 \%$ below the national $150 \mu \mathrm{g} / \mathrm{m}^{3}$ standard. The decreases were sharpest in Alameda County. In particular, Livermore decreased the number of exceedances of the State 24-hour standard from twelve days to five days. Emissions of particulates from all permitted sources at SNL/California totaled less than 1 ton in 1992. Compared to other industrial sources in the area, this amount is insignificant.

The national ambient air standard for ozone ( $0.12 \mathrm{ppm}$ ) was exceeded on two days in 1992. There were 23 days recorded over the State $0.09 \mathrm{ppm}$ standard, which tied the number in 1991. Livermore fell from 17 days to 14 days, but continued to have the most State exceedances. In the Bay Area, motor vehicles are the greatest source of ozone precursor ga jes (about $42 \%$ of all reactive organic gases and $54 \%$ of nitrogen oxides). Emissions of reactive organic gases and nitrogen oxides from all permitted sources at SNL/California totals less than 1 ton/yr. Compared to other industrial emissions in the area, this amount is insignificant.

\section{Wastewater Control Program}

The primary goal of the Federal Clean Water Act is to protect and restore the integrity of the nation's waterways. The Act establishes the National Pollutant Discharge Elimination System (NPDES), which requires permitting of all pointsource liquid effluent discharges. These permits contain specific criteria for discharging liquids to waterways. The State of California has authority to enforce the requirements of the Clean Water Act. Permitting and enforcement is handled by the LWRP. SNL/California has a permit from the LWRP for discharging wastewater to the municipal sewer system. This permit

SNL/CA Site Environmental Report for 1992 


\section{Environmental Program Information}

contains specific pollutant limitations and monitoring requirements.

Over the past few years, more stringent regulations governing industrial wastewater discharges to public sewer systems have gone into effect. SNL/California has always maintained a program to control liquid effluents. This program incorporates administrative and engineering controls to prevent contaminated wastewater from being discharged to the municipal sewer system.

In 1992, SNL initiated an effort to improve its ability to monitor and control wastewater discharges. This involved establishing a formal, corporate-level Wastewater Discharge Program.

SNL/California, in turn, is developing a site-specific implementation plan and operating procedures. The goals of this program are to:

- minimize the volume and concentration of toxic pollutants in wastewater discharges using best available technology (BAT);

- ensure environmentally acceptable and cost-effective treatment and disposal; and

- ensure that wastewater discharges are in full compliance with DOE Orders, Federal and State regulations, and local permit conditions.

\section{Liquid Effluent Controls}

The Liquid Effluent Control Systems (LECS) are key elements of SNL/California's wastewater management. The LECS comprise large, monitored, holding tanks that collect and retain wastewater generated at key facilities. These systems allow SNL/California to analyze the wastewater and verify that its constituents are within acceptable limits before discharging it to the sanitary sewer system.

SNL/California has five LECS in operation: Bldg. 913 (Electroplating Laboratory), Bldg. 910 (Printed Wiring Laboratory), Bldg. 961 (Hazardous Waste Management), Bldg. 968 (TRL), and Bldg. 906

(Combustion Research Facility). The IMTL (Bldg. 941) is also equipped with a LECS.

\section{Liquid Effluent Monitoring}

In 1992, three key improvements were made to the monitoring of wastewater effluents:

1. a new flow-proportional composite sampler was installed at the site sewer outfall;

2. the number and frequency of chemical and radiochemical analyses were expanded at both the LECS and the site sewer outfall; and

3. the system for managing and storing on-line monitoring data was upgraded.

\section{Sewer Diversion Facility at LLNL}

The combined SNL/California and LLNL sewage effluent is discharged to the City of Livermore municipal sewer system at the northwest corner of the LLNL site. To better control effluents and increase protection of the LWRP, LLNL and SNL/California constructed a sewer diversion facility at LLNL. This system will be able to retain on-site approximately 200,000 gallons of contaminated sewage, if necessary, for further evaluation. 


\section{Environmental Program Information}

\section{Waste Management Programs}

RCRA, as amended by the Hazardous and Solid Waste Amendments of 1984, requires a comprehensive program for the management of hazardous wastes from generation to ultimate disposal. One of the primary goals of RCRA is to reduce the volume and toxicity of wastes and to minimize the amount of waste requiring land disposal. The California Hazardous Wastr Control Law is similar, but more restrictive than RCRA. The EPA authorized the State to assume RCRA authority in August 1992. This is enforced by the DTSC of the Cal/EPA.

Hazardous waste activities at SNL/California include collection, on-site transportation, consolidation, commingling, treatment, and storage of energetic, radioactive, mixed, and nonradioactive hazardous wastes. SNL/California has not and does not plan to dispose of hazardous wastes at the site. Small quantities of energetic wastes, medical wastes, and classified film have been incinerated on-site.

SNL/California maintains a Safe Operating Procedure, a contingency plan, and a closure plan for its small incinerator. These plans are reviewed and updated annually. A Part B Application, with Subpart O exemption for operation of the incinerator, has been submitted to the EPA and the Cal/EPA. The incinerator has not been used since December 1991.

In 1989, SNL/California implemented a computerized tracking system for all hazardous, mixed, and radioactive wastes. This system tracks wastes from point of generation to final disposal. Table 6-1 summarizes the 1992 waste generation rate at SNL/California.

In 1992, SNL/California began the work necessary to tie the waste management tracking system into the site-wide chemical inventory system. This effort will continue in 1993 with anticipated implementation in early 1994.

\section{Hazardous Waste}

Hazardous waste is defiıed as a material with no further end use, which is not radioactive, but does contain constituents that may be harmful to the public health or the environment. RCRA wastes are those wastes regulated by the EPA. Non-RCRA wastes are regulated by the Cal/EPA.

All nonradioactive wastes generated at SNL/California are sent to permitted commercial facilities for treatment or disposal. Table 6-2 lists the hazardous waste transportation and disposal companies SNL/California used in 1992. Sandia shipped an average of approximately $12,000 \mathrm{~kg} / \mathrm{month}$ of chemical waste off-site for disposal in 1992. SNL/California is storing a very small amount (a few grams) of dioxin (TCDD) on-site, because no treatment or storage facility exists.

SNL/California and the DTSC have a written agreement that allows on-site storage of this material longer than the one-year limit established by RCRA.

\section{Radioactive Waste}

SNL/California generates very small amounts of radioactive waste, which will be sent to the Nevada Test Site (NTS) for burial. SNL/California is currently working with DOE/Nevada Operations Office (NVO) to implement an approved waste certification program. Approximately $1,837 \mathrm{ft}^{3}$ of low-level radioactive waste was in storage as of December 31, 1992. No radioactive waste was shipped in 1992 . No transuranic or high-level radioactive wastes are generated at this site. 


\section{Environmental Program Information}

\section{Mixed Waste}

Mixed waste is a hazardous waste that is also contaminated with radionuclides. Small quantities of RCRA-regulated mixed waste are stored on-site at the Hazardous Waste Management Facility. Except for scintillation solutions, mixed waste will remain on-site until a DOE- and EPA-permitted disposal facility exists.

$\mathrm{SNL} /$ California is storing $30 \mathrm{ft}^{3}$ of RCRA-regulated mixed waste (as of December 31, 1992). SNL/California is also storing $242 \mathrm{ft}^{3}$ of non-RCRA-regulated mixed waste. This waste consists of oil, ethylene glycol, or tellurium that have been contaminated with depleted uranium or tritium. NTS will not accept the non-RCRA mixed waste for disposal. SNL/California is searching for other DOE locations to dispose of the non-RCRA waste. Locating a disposal facility and preparing the required disposal documentation for this waste stream will be a priority in 1993.

\section{Waste Minimization and Pollution Prevention Awareness}

SNL/California has supported various waste minimization activities since 1985 . These efforts have evolved into a structured and organized Waste Minimization and Pollution Prevention Awareness Program (WM\&PPAP). The principal objective of the WM\&PPAP is to maximize all opportunities for eliminating or minimizing waste through source reduction, recycling, and treatment in all corporate operations. The program reflects ongoing efforts to make pollution prevention and waste minimization part of the site's operating philosophy. The increases in waste management costs and the public's interest in environmental issues provide added incentives for an effective program.

SNL/California has implemented a variety of waste minimization techniques. These have been supported by employee training programs aimed at reducing waste while still meeting the company's requirements for quality, productivity, safety, and environmental compliance.

A key element of the WM\&PPAP is the development of baseline information on waste generation. A corporate Waste Minimization Steering Committee was established in July 1992 to assist in the ongoing evaluation and evolution of the waste minimization program. Its primary functions are to make all SNL/California employees aware of the WM\&PPAP; identify tasks to implement the program; and provide a mechanism for communicating waste minimization issues within the $\mathrm{SNL} /$ California community and to the public. The Waste Minimization Steering Committee is responsible for developing, designing, creating, and overseeing implementation of waste minimization projects. Waste generators are responsible for implementing the program.

In 1992, SNL/California began several waste minimization and pollution prevention activities. These efforts demonstrate both the commitment and involvement of SNL/California's management and staff. Significant accomplishments are described below.

- For the second consecutive year, $\mathrm{SNL} /$ California has reduced the amount of RCRA and non-RCRA hazardous waste, and sanitary waste generated on-site. 


\section{Environmental Program Information}

- WM\&PPAP training has been incorporated into several required ES\&H training courses and is provided at monthly new-hire ES\&H orientations.

- SNL/California hosted an Earth Day exhibit, which included internal programmatic activities, external regulatory agencies, and commercial representatives.

- The Solvent Substitution Technical Advisory Committee and CFC Elimination Working Groups were formed to help users find less hazardous or nonhazardous solvents and cleaning agents.

- The WM\&PPAP has implemented a training and awareness activity to promote the substitution of safe alternatives for hazardous chemicals whenever possible.

- The City of Livermore Commuter Survey was analyzed to determine how SNL/California can design and implement a transportation program to reduce motorized vehicle trips to the site.

- A site-wide Waste Minimization Activities Survey was conducted to help determine the current usage of waste minimization practices.

- Mulching mowers were bought and are being evaluated for effectiveness in reducing yard waste. In addition, SNL/California is studying a composting process to use yard waste generated on-site.

- Toner cartridge recycling began in December 1992; 63 toner cartridges were recycled, netting a revenue of $\$ 144.00$.
- The SNL/California Materials Management Department, General Stores, is stocking more environmentally safe products.

- SNL/California has supported a metal recycling program for several years. The metal recycled in 1992 netted $\$ 17,023.24$ in revenue.

- The Property Reapplication and Reclamation Department reassigns excess equipment to internal or external organizations.

- The entire site is participating in a paper recycling program. In 1992, more than 22 tons of paper were collected for recycling.

- Classified paper waste has been recycled for the past several years. SNL/California's classified waste is sent to LLNL for processing. The waste is then shipped to a paper products manufacturer.

- Tires from the Maintenance Department are recycled as a part of LLNL's tire recycling program.

- SNL/California is negotiating a contract to recycle wood.

- The Waste Management Group recycles hazardous wastes whenever possible. Some examples are batteries, mercury, coolants, petroleum oil, empty drums, and lead. Silver from photo chemicals (fixers and developers) is reclaimed whenever possible. Tritium used at the TRL is recaptured and reclaimed to the maximum extent possible. 


\section{Environmental Program Information}

- The wastes generated by laboratory processes are assessed to determine if they can be eliminated or reduced. The reassessments are called "Process Waste Assessments" (PWAs). Summarized in the next section are the PWAs completed in 1992. They include the Electroplating Research Facility, the Photography Laboratory, and the Printed Wiring Laboratory.

All regulated waste generation information is tracked by the Waste Management Group. Nonhazardous waste information is tracked and maintained by the Facilities Operations and Property Management Departments. The quantities listed in Table 6-3, except for sanitary waste, are based on the manifested shipment database for calendar years 1991 and 1992, respectively. Table 6-3 also shows the percentage reduction of waste and the results of SNL/California's recycling efforts in 1992.

\section{Process Waste Assessments}

Although SNL/California reduced the amount of waste generated on-site in 1992, continued efforts to measure actual waste generated by specific activities are necessary. The PWA program has been developed under the direction of DOE to evaluate the activity and management of materials in particular processes so that waste minimization opportunities can be identified and instituted. A third party assessor works with the process personnel to determine how wastes are being generated and how much. Also, to comply with Senate Bill 14, SNL/California is assessing the major waste streams generated on-site.
Working with process personnel heightens their awareness of waste reduction activities.

In 1992, several processes were targeted for PWA. These were chosen based on the definition of the process, the waste classification (hazardous vs. nonhazardous), and waste quantity. Three PWAs were completed in 1992. The results are briefly summarized below. Also discussed are four source reduction evaluations performed by SNL/California in 1992. These evaluations have the same purpose as PWAs, but are not as detailed.

\section{Electroplating Research Facility (PWA)}

The Electroplating Research Facility's purpose is to study the electroplating process (not production of plated parts). The facility personnel examine electroplating technology alternatives that will improve the safety and health of the employees and protect the environment without compromising product quality. They are currently studying the replacement of copper cyanide with copper pyrophosphate and the replacement of cadmium plating with zinc alloy plating.

The Electroplating Research Facility contributes a small amount (less than one percent) to SNL/California's total waste stream. However, the facility personnel are actively exploring ways to further reduce waste. As a standard procedure, parts are first rinsed over the chemical solution tank to minimize water waste. This procedure also reduces the drag-out of metals entering the rinse water waste. By eliminating proprietary plating/cleaning processes, facility personnel have reduced the number of process tanks and waste streams in their operations. 


\section{- Environmental Program Information}

Photography Laboratory (PWA)

The Photography Laboratory was recently remodeled. It resumed full operation in 1992. Processes were upgraded, new chemistries were implemented, and a rinse water recirculation system was installed. As a result, the amount of hazardous waste generated has been significantly reduced. Specifically, waste water effluent has been reduced by $92 \%$; the volume of developer has been reduced from 60 gallons to 9 gallons; the use of formaldehyde in the stabilizer has been eliminated; and the amount of raw materials used has been significantly reduced. In addition, silver in photographic processing waste is recovered at an off-site facility.

\section{Prototype Printed Wiring Laboratory (PWA)}

The Prototype Printed Wiring Laboratory was relocated and underwent extensive equipment upgrades, process changes, and operational improvements in 1989.

Although the working volume of the chemical baths was doubled during the facility upgrade, many of the upgrades resulted in waste reduction. For instance, the automated processing line greatly reduced waste generated. Also, the lives of the chemical baths have been extended by the following features:

- regulation of the bath temperature, agitation and/or aeration, and electrochemical controls;

- a monitoring system for the filtration and work load throughput (square foot processed), and the addition of organic brighteners;

- reduced drag-out loss by automation; and
- programmable alarm levels and interlocks to alert operators and/or shut down the system.

The rinse water necessary for the process also has been dramatically reduced.

Additional process improvements are limited because the spent chemical baths are inherent to the process. The most effective waste reduction technique no' $w$ in use is a training program to teach employees how to closely monitor and troubleshoot the chemical bath solutions. Two employees are in training.

The facility's staff is considering using a solvent recovery system.

\section{Large Contaminated Equipment (Inorganic Solid Waste) (Source Reduction Evaluation)}

Much of SNL/California's research requires state-of-the-art equipment, which must be renovated or replaced frequently. Often, equipment has been contaminated with hazardous materials and must be managed as hazardous waste. Hazards are removed from the equipment when feasible, as long as more hazardous waste is not generated as a result. Parts or contents are reapplied or recycled, if possible.

The methods available for further reducing waste generated by large contaminated equipment are primarily administrative controls. For instance, implementation of the WM\&PPAP at the line organization level emphasizes operational improvements to reduce wastes. The following activities are encouraged: using nonhazardous alternatives for hazardous chemicals, controlling the chemical inventory, and increasing the awareness of the importance of segregating hazardous and nonhazardous wastes.

SNL/CA Site Environmental Report for 1992

6-11 


\section{Environmental Program Information}

Changes in hazardous waste regulations also affect the amount of large contaminated equipment waste generated. The total quantity of this type of waste generated at $\mathrm{SNL} /$ California is not expected to decline significantly.

A full PWA will be completed in 1993.

\section{Empty Containers (Source Reduction Evaluation)}

Because many different chemicals are used throughout the site, empty containers are a difficult waste to reduce. However, the number of empty containers is expected to decline because operations are being improved, nonhazardous chemical alternatives are being used (where product quality is not affected), and better administrative controls are being used. For instance, the site's new chemical inventory control system allows users to identify if needed chemicals are already on-site, thus eliminating duplicate orders for chemicals.

The Waste Management Group compacts all empty containers to reduce waste volume. Also, when full or partially full containers are disposed of, compatible chemicals are consolidated in 55-gallon drums and the empty containers are compacted.

An operational change under investigation is teaching users how to rinse empty containers according to the current regulations. If the rinse water can be used in their process (recycled), they can reduce the amount of waste generated and safely dispose of their empty containers.

A full PWA will be completed in 1993.

\section{Machine and Fabrication Shop (Source Reduction Evaluation)}

The primary waste generated in the Machine and Fabrication Shop is spent coolant. Now, the coolant is sent off-site for recycling. Waste reduction alternatives are operational improvements and administrative controls.

One potential operational improvement is a coolant recycling process on-site. According to the recycling equipment's marketing literature, the equipment can reduce the amount of coolant waste generated by approximately $50 \%$. However, a cost/benefit analysis showed that this option is not economically feasible. Several factors were considered:

- the waste disposal costs vs. the initial equipment cost,

- system installation,

- personnel training, and

- system maintenance.

The Machine and Fabrication Shop does not generate enough spent coolant waste to justify recycling equipment. However, this option will be revisited if the amount of waste increases or if a more economical means becomes available.

This facility has replaced the solventbased degreaser with a biodegradable, noncaustic detergent, parts washer. Also, a centralized deionized water recirculation and filtration unit has been installed on the electrical discharge machines.

Other administrative waste minimization efforts include waste segregation, lead usage reduction, and the restriction of beryllium-copper alloy machining.

A full PWA will be completed in 1993.

\section{Vehicle Maintenance Facility (Source Reduction Evaluation)}

The Vehicle Maintenance Shop is responsible primarily for the routine maintenance of $\mathrm{SNL} /$ California motorized carts and site 


\section{Environmental Program Information}

support equipment. The major wastes generated are used oil and filters, oily rags, and used batteries. Waste oil and batteries are sent off-site for recycling.

To reduce waste, the facility personnel have done the following:

- evaluated the service schedule of vehicles; for those not used regularly, the routine maintenance schedule was extended from three months to six months (this extension alone accounts for almost a $50 \%$ reduction in waste),

- replaced the asbestos brake shoes on the vehicles with organic shoes;

- begun using an air-powered spray can instead of disposable aerosol cans;

- conducted a study to determine which batteries were providing the longest service time;

- replaced a hazardous cleaning solvent with a citrus-based solvent to reduce the toxicity of waste generated;

- begun salvaging cart parts to repair other carts; and

- begun sending bicycle and cart tires to LLNL to be included in the LLNL tire recycling program.

A full PWA will be completed in 1993.

\section{Chemical Information System}

The Environmental Protection Department implemented a site-wide chemical information system/Material Safety Data Sheet management system in April 1992. This system is designed to help SNL/California more effectively comply with Federal and
State regulations and DOE Orders, and to improve the operating efficiency in chemical work areas.

The system is a computer database that tracks chemical containers in facilities by bar-code labels. It has several unique features, including flexible software, which will permit SNL/California to customize it for the inventory's special needs. The system will provide detailed information on chemical usage on-site, thus supporting numerous programs including:

- Employee Right to Know/MSDS,

- Emergency Planning and Community Right-to-Know Act (EPCRA/SARA Title III),

- Waste Minimization,

- Hazardous Materials Management Plan,

- Spill Information and Emergency Preparedness,

- Fire Protection,

- California Proposition 65, and

- General resources for audits, surveys, and information.

\section{Toxic Substance Control Act (TSCA) CoMplaAnce}

The Toxic Substance Control Act (TSCA) establishes regulations to control use of and exposure to new industrial chemicals. The TSCA identifies toxic substances and regulates their manufacture, use, storage, handling, and disposal. It requires pre-manufacturing notification and evaluation of new chemicals to assess the health and environmental risks. The TSCA also regulates the use, inspection, and disposal of PCBs. 


\section{Environmental Program Information}

SNL/California has removed all PCB transformers in response to a major sitewide electrical upgrade, conducted over the last few years. Most remaining PCB-contaminated electrical equipment (concentrations of 50 to $500 \mathrm{ppm}$ ) was removed or retrofitted with non-PCB-contaminated mineral oil. Only a few PCB-contaminated ballast switches and capacitors now remain on-site.

\section{National Environmental Policy Act (NEPA) COMPLIANCE}

NEPA is the basic national charter for protection of the environment. This law requires that $\mathrm{SNL} /$ California protect the environment by reviewing each new or changing project on-site for environmental impacts. Environmental issues to be considered include air emissions, water outlets, waste generation and minimization, and the human environment (workers and the surrounding community). NEPA documents serve as a vehicle for the public to participate in DOE's decision-making process.

A major site NEPA document, the Environmental Impact Statement (EIS), was published in August 1992. On January 20, 1993, the Secretary of Energy signed the Record of Decision, which formally allows DOE to continue operations at LLNL and SNL/Caiifornia. The EIS discusses SNL/California's existing and proposed (for the next five to ten years) mission and projects from an environmental perspective.

The EIS provides a base of environmental information according to which SNL/California evaluates each proposed project. It discusses SNL/California's con- tinuing operations to provide routine services to the whole site. Such routine operations include maintenance activities, administrative duties, and temporary office space and support activities.

Each proposed new or modified project (beyond what is covered in the EIS) must be evaluated according to NEPA guidelines. The DOE Albuquerque Operations Office has created an Environmental Checklist to help SNL personnel evaluate the level of NEPA documentation required for the project. SNL/California submits the Checklist to DOE for review and comment. (SNL/California does not approve its own review of proposed projects.) Only after DOE has approved the Environmental Checklist may SNL/California proceed with the project.

In 1992, the following projects were submitted to DOE for NEPA review:

- Categorical Exclusions based on research and development benchscale work to verify systems:

- Stereolithography, a system to produce prototype hardware for engineering evaluations. It uses nonvolatile resins and solvents for environmentally safer operation.

- LIDAR Testbed Project, a laser diagnostics project expanding existing on-site experimentation.

- Categorical Exclusion applicable to facility operation:

- Vital Records Storage Building, a small support structure for protecting and saving documents. 


\section{Environmental Program Information}

- Asbestos Management FY92-continuous program to remove and dispose of asbestos found on-site through maintenance or remodeling projects.

- Temporary Office Trailer-support structure to house summer employees.

- Temporary Office Trailer for Auditors-support structure to accommodate auditors from organizations outside of SNL/California.

- Maintenance Material Storage Facility-support structure to house chemicals and associated materials used by the Maintenance Department; this is a controlled environmental storage area.

- Health Care Facility-support structure to relocate the existing facility to another facility on-site.

- Categorical Exclusion applicable to a general plant project (Bus Turnaround):

- relocation of the public bus turnaround from a high-traffic area to a low-traffic, safer turnaround area.

- Categorical Exclusion applicable to Environmental Restoration:

- in-situ bioremediation pilot study for analysis of method to clean up oil spills.

- Air conditioning work for Bldg. 964:

- air conditioning equipment added to accommodate the electrical equipment in this facility.
- East Arroyo Seco Security Structure/Fence:

- completion of the security fencing for the site per the requirements of the Security guidelines.

Note: "Categorical Exclusion" is defined as a category of actions that do not individually or cumulatively have a significant effect on the quality of the human environment and require no further NEPA documentation.

As part of SNL/California's internal goals to improve awareness and comprehensive discussion of proposed projects for environmental review, a video has been developed for the use of SNL/California staff on-site. The NEPA Program staff has provided awareness training to more than half the SNL/California staff using this video and accompanying pamphlet. The objectives of the video are to familiarize personnel with NEPA, to show them how using the Environmental Checklist can help them with other regulatory compliance areas, and to provide them with a contact for help analyzing their proposed projects.

Interdisciplinary teams are a part of the review process for each NEPA document submitted to DOE. The line organization staff, the facilities management group, and ES\&H professionals provide comments and guidance for each proposed project.

The NEPA coordinators meet monthly with the NEPA Compliance Officer to review the status of projects and to share information.

\section{Pollution Abatement Projects}

SNL/California continuously strives to keep emissions to the environment as low 


\section{Environmental Program Information}

as reasonably achievable. As a part of this effort, SNL/California is involved in several pollution abatement projects, which are described below, primarily at the TRL.

The TRL at SNL/California is a research and development facility designed for a wide range of experiments using various forms of tritium. The TRL employs extensive administrative and engineering controls to ensure safe handling of tritium. It has glove boxes coupled with secondary containment and gas cleanup systems to minimize releases of tritium. Two central decontamination systems are used at the TRL: the Gas Purification System (GPS) and the Vacuum Effluent Recovery System (VERS). In 1992, there were several major changes associated with the TRL operation.

\section{Phase Out of Tritium Research}

SNL/California is planning to phase out tritium operations at the site within the next five years, and following formal approval by DOE, the TRL will be transitioned to other uses. SNL/California is developing a comprehensive plan for the safe cleanup and transition of the facility. This plan will follow the guidance of DOE Order 5820.2A, Decommissioning of Radioactively Contaminated Facilities. ${ }^{37}$ The first phase of the project is to transfer experiments to other DOE sites, reduce the tritium inventory at the TRL to zero, and remove hazardous and radioactive wastes from the facility. This phase will include facility characterization and environmental review. The goal to eliminate tritium from the site has been set for fiscal year 1993. The complete cleanup and transfer process is expected to take three to five years.

\section{Gas Purification System Upgrade}

The GPS removes various forms of tritium from glove box air. Since its design in 1974, some of its components are no longer manufactured or serviceable. Consequently, in 1989, SNL/California initiated efforts to upgrade the GPS control system.

\section{Tritium Monitors}

Sixty fixed-station and six portable tritium monitors are used at the TRL. The monitors are used to check for tritium contamination in air, process systems, and gases released to the environment. The monitors have been procured over a period of fifteen years and are refurbished at the rate of five to ten per year. In addition to refurbishment and repair, the monitors are calibrated annually.

\section{TRL Stack Monitoring Upgrade}

After the two decontamination systems have removed tritium from the TRL effluent, it is vented to the atmosphere through a $30-\mathrm{m}$ stack. The exit gas is monitored as it passes through the stack. The stack monitoring system can detect instantaneous or continuous releases of tritium in real-time. $\mathrm{SNL} /$ California has begun an effort to improve the stack sampling configuration to obtain a more representative sample. The plans involve relocating the sampling points downstream of the exhaust fan. This new system was installed and operational by the end of 1992 . 


\section{Environmental Program Information}

\section{Table 6-1. Average Daily Waste Generation}

Rate at SNL/California.a

\begin{tabular}{lc}
\hline Waste & $\begin{array}{c}\text { Generation Rate } \\
\text { (kg/day) }\end{array}$ \\
\hline Hazarous chemical & 510 \\
Mixed (State-regulated) & 0.48 \\
Mixed (Federal-regulated) & 3.7 \\
Radioactive & 40 \\
\hline
\end{tabular}

aBased on twenty working days per month.

Table 6-2. SNL/California Waste Transporters and Disposal Companies Used in 1992.

\begin{tabular}{ll}
\multicolumn{1}{c}{ Company } & \multicolumn{1}{c}{ Function } \\
\hline Aptus Inc. & Ireat \\
Bethlehem Apparatus & Recycle \\
BFI & Transport and treat \\
BROCO, Inc. & Treat \\
California Solvent Recyclers & Transport \\
Chemical Waste Mgmt Co. & Transport \\
Drew Resources & Transport and treat \\
Evergreen Environmental & Transport \\
Services & \\
Evergreen Oil, Inc. & Recycle \\
Great Western & Transport \\
Kettleman Hills & Landfill \\
M. P. Environmental & Transport \\
Norris Industries, Inc. & Treat \\
Quadrex & Treat \\
Romic Chemical Co. & Treat and recycle \\
S.D. Meyers & Transport, recycle and treat \\
Southern California Chemical & Treat \\
Thomas Gray & Transport \\
Trade Waste Incineration & Treat \\
Trojan Batteries & Transport and recycle \\
TWI \& SCA & Treat \\
Western Drums & Transport and recycle \\
Western Drums & Transport and recycle \\
\hline
\end{tabular}




\section{Environmental Program Information}

\section{Table 6-3. SNL/California Site Waste Reduction Summary.}

\begin{tabular}{lccc}
\multicolumn{1}{c}{ Waste Type } & $\begin{array}{c}\text { Waste Shipped } \\
\mathbf{1 9 9 1}(\mathbf{k g})\end{array}$ & $\begin{array}{c}\text { in } \\
\text { Waste Shipped } \\
\mathbf{1 9 9 2}(\mathbf{k g})\end{array}$ & in \\
\hline RCRA hazardous waste & 52,000 & 31,000 & $-40 \%$ \\
$\begin{array}{l}\text { California-regulated (non-RCRA) } \\
\text { hazardous waste }\end{array}$ & 23,000 & 22,000 & $-4 \%$ \\
Low-level mixed waste & 130 & 250 & $+92 \%^{\mathrm{a}}$ \\
Low-level waste & 0 & 0 & 0 \\
TSCA (PCBs/asbestos) & 9,200 & 22,000 & $+139 \% \mathrm{~b}$ \\
Sanitary waste & $1.423 \times 10^{6}$ & $1.347 \times 10^{6}$ & $-5.3 \%$ \\
\hline
\end{tabular}

aThis number does not reflect an increase in waste generation. Shipments had been curtailed and were resumed in 1991 and continued at a normal level during 1992; therefore, more waste was shipped in 1992.

This number represents a total of two drums shipped in 1992.

bThis increase was a result of asbestos abatement projects.

Table 6-4. SNL/California Site Recycling Activities (Nonhazardous).

\begin{tabular}{lcc}
\hline \multicolumn{1}{c}{ Material } & 1991 (tons) & 1992 (tons) \\
\hline Office Paper & 3.0 & 22.47 \\
Aluminum & 0.17 & 0.50 \\
Scrap Metals & 42.00 & 50.00 \\
\hline
\end{tabular}




\section{7 - Groundwater Protection Program}

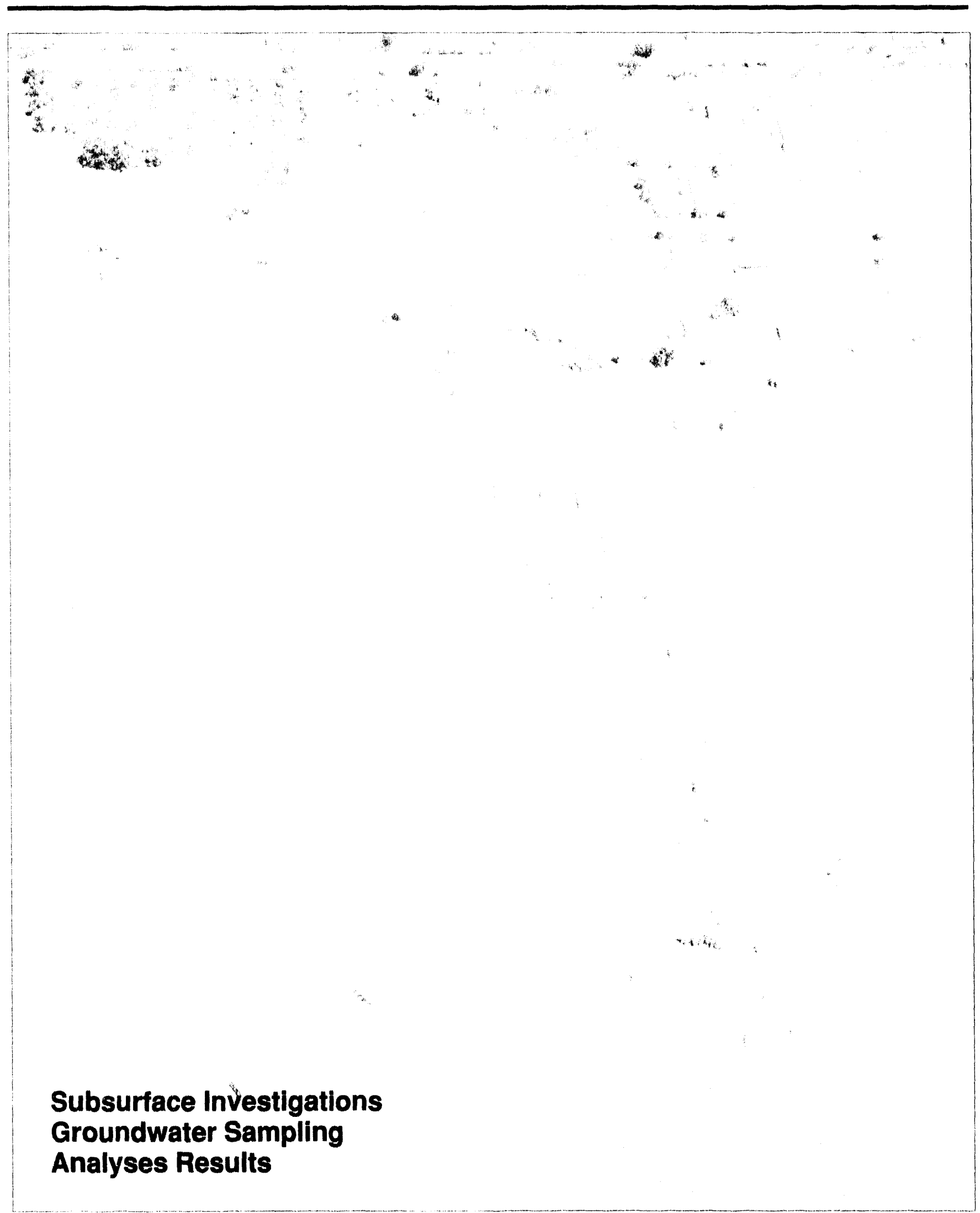




\section{Groundwater Protection Program}

The SNL/California Groundwater Protection Management Program Plan (GWPMPP) was issued on September 14,1990, 38 to assure compliance with applicable Federal, State, and local environmental protection laws and regulations, Executive Orders, and internal department policies. The GWPMPP's objective is to document a management program for ground water protection and remediation. Specifically, it addresses CERCLA/SARA, RCRA, and SDWA. The plan includes the following elements, as required by DOE Order 5400.1:5

- documentation of the quantity and quality of the groundwater,

- identification of sites that may be contaminated with hazardous substances, and

- a remedial action program, which is directed by the RWQCB and contained in DOE directives.

The Groundwater Sampling Program was designed as a part of the Environmental Restoration Program to monitor the effectiveness of SNL/California's pollution control measures and to make sure that contaminants are not entering domestic water supplies.

The Environmental Restoration Program evaluates SNL/California's inactive waste disposal sites, spill locations, and waste management practices to determine if there is an adverse impact on the environment, and to develop any necessary remedial actions. This program will also better define the ground water system at SNL/California to support the remediation of groundwater that might become contaminated in the future. The uppermost waterbearing unit, which may be considered a water table aquifer, and the deeper confined/partly confined aquifers at SNL/California are not a source of human or livestock drinking water, nor are they a water source for agricultural purposes.

A Remedial Investigation/Feasibility Study (RI/FS) is being conducted at SNL/California to fully assess the nature and extent of the release of hazardous substances. It encompasses four tasks:

- Fuel Oil Spill-Assessment and Remediation

- SNL/California Miscellaneous Sites [Arroyo Seco (AS3, AS4)]

- Navy Landfill- Assessment and Remediation

- Trudell Auto Repair StationAssessment and Remediation.

The remediation activities are being done under RWQCB order. ${ }^{9,10}$

\section{SUBSURFACE INVESTIGATIONS}

\section{Fuel Oil Spill Site}

In June and November, 1984, seven groundwater monitoring wells (FT-1A, FT-1B, FT2A, FT-4C, FT-4D, FT-5B, and FT-6A) were installed at the Fuel Oil Spill site (FOS in Fig. 7-1) as a means of assessing the impact of a 59,000-gallon diesel fuel oil spill on the subsurface. Between January 1986 and August 1988, seven deeper wells (FT-10, FT11, FT-16, FT-19, FT-20, FT-21, and FT-22) were installed after drought conditions had lowered the water table beyond the depth of the first seven wells, leaving them dry and unusable. During the first quarter of 1992, wells FT-19, FT-20, FT-21, and FT-22 contained enough water to allow proper 


\section{Groundwater Protection Program}

sampling. The remaining wells were dry throughout the year or contained water levels too low to collect an adequate sample. By the fourth quarter, none of the wells could be sampled properly.

\section{Arroyo Seco Locations}

In January 1986, four wells were installed at locations along the Arroyo Seco (AS3 and AS4 in Fig. 7-1), which traverses the site. Locations of three of the wells (AS-3A, AS-3B, and AS-3C) were based on primary recharge areas and expected surface runoff
Figure 7-1. Groundwater monitoring well locations on the SNL/California site.

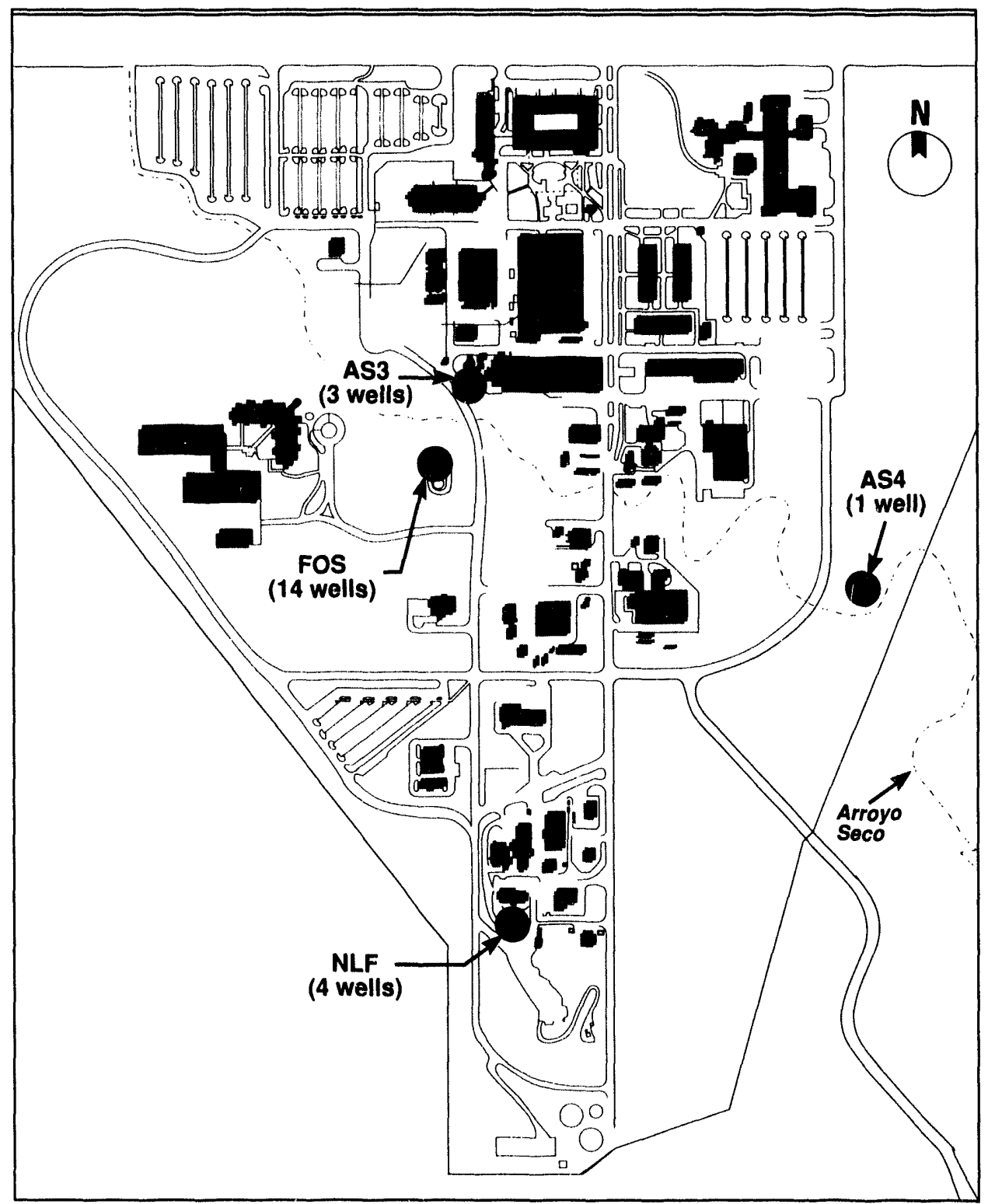




\section{Groundwater Protection Program}

points at the SNL/California site. AS-3C was installed at a much greater depth to monitor the third aquifer. (Water-bearing zones are numbered consecutively downward from the ground surface.) A fourth well, AS4, installed upgradient of $\mathrm{SNL} /$ California, was intended to function as a background well. During the first quarter of 1992, wells AS-3B, AS-3C, and AS4 contained enough water to allow proper sampling. By the third quarter, all the wells were dry or could not be sampled properly. In the fourth quarter, AS-3B and AS-3C contained enough water to allow proper sampling.

\section{Navy Landfill Site}

In January 1986, one well (NLF-1) was installed at the Navy Landfill site, an abandoned landfill used in the 1940s and 1950s for construction debris. Three additional wells (NLF-2, NLF-3, and NLF-4) were installed in June 1988 (Fig. 7-1). All four wells are sampled quarterly.

\section{Trudell Auto Repair Site}

One well (MW-406) was installed at the Trudell Auto Repair Site (located in the DOE buffer zone) to monitor any leaks from previous site activities. RWQCB approved the site closure in November 1990. SNL/California still maintains an active quarterly sampling program for MW-406, even though the site is closed.

\section{Groundwater SAMPLING}

International Technologies, an environmental contractor, conducted quarterly sampling of the groundwater monitoring wells in 1992. Due to the ongoing drought, many of the wells could not be sampled because they were dry or had extremely low water levels. Ability to sample was determined by a hydrogeologist, who checked the water level and condition of the wells. If sampling was possible, the water was checked for stability of $\mathrm{pH}$, temperature, and specific conductivity before samples were taken. Three purge volumes were removed when possible. International Technologies follows established QA/QC procedures. These include chain-of-custody reporting and analyzing trip and equipment blanks to ensure the validity of the data.

LLNL reports data from ground water monitoring wells installed on $\mathrm{SNL} /$ California property as part of the LLNL groundwater investigation project. Results are reported in LLNL's Monthly Progress Report. The RWQCB requires quarterly reports to summarize groundwater-related project activities at

SNL/California. Groundwater monitoring requirements have been upgraded and are defined in the RWQCB Waste Discharge Orders 88-142 and 89-184 and in memoranda from the RWQCB to DOE. ${ }^{9,10}$

\section{ANALyses Results}

Table 7-1 indicates the physical and chemical water quality parameters and their corresponding detection limits for the groundwater monitoring wells. Constituents include metals, VOCs, and fuel hydrocarbons. Table 7-2 summarizes quarterly sampling data, noting the highest positively detected parameter for each well in 1992.

None of the samples analyzed in 1992 exceeded the MCLs for organic compounds. Samples were also analyzed for total uranium, radium-226 and -228 , and 


\section{Groundwater Protection Program}

tritium. No samples exceeded the MCLs for radioactive contaminants.

Samples collected from the Navy

Landfill wells showed levels of chromium

up to $8.4 \mathrm{mg} / \mathrm{L}$, which exceeded the primary DWS of $0.05 \mathrm{mg} / \mathrm{L}$. Samples collected from these wells showed nitrate/nitrite levels up to $64 \mathrm{mg} / \mathrm{L}$, which exceeds the DWS MCL of $10 \mathrm{mg} / \mathrm{L}$. No water from these wells is used for drinking water or agriculture.

Most of the wells at the Fuel Oil Spill site were dry or too low to sample at the beginning of 1992. By the end of 1992, none of the wells could be sampled.

The Trudell Auto Repair site well (MW-406) was dry throughout 1992. 


\section{Groundwater Protection Program}

Table 7-1. Water Quality Parameters and Detection Limits for SNL/California Monitoring Wells.

\begin{tabular}{|c|c|c|c|c|c|}
\hline $\begin{array}{c}\text { Physical and Chemical } \\
\text { Parameters }\end{array}$ & Locations $^{a}$ & $\begin{array}{l}\text { Detection } \\
\text { Limit }(m g / L)^{b}\end{array}$ & $\begin{array}{l}\text { Radioactivity } \\
(\mathrm{pCl} / L)^{b}\end{array}$ & Locations $^{a}$ & $\begin{array}{l}\text { Detection } \\
\text { Limit }\end{array}$ \\
\hline Antimony & $\overline{N L F}$ & 0.06 & Total uranium & NLF, ASL, FOS & 1.0 \\
\hline Arsenic & NLF & 0.002 & Radium-226 & NLF, ASL, FOS & 0.3 \\
\hline Barium & NLF & 0.05 & Radium-228 & NLF, ASL, FOS & 0.85 \\
\hline Beryllium & NLF & 0.0005 & Tritium & NLF, ASL, FOS & 1000 \\
\hline $\begin{array}{l}\text { Bicarbonate alkalinity } \\
\left(\text { as } \mathrm{CaCO}_{3}\right)\end{array}$ & NLF & $-^{c}$ & & & \\
\hline Cadmium & NLF & 0.05 & & & \\
\hline Calcium & NLF & 0.5 & & & \\
\hline $\begin{array}{l}\text { Carbonate alkalinity } \\
\left(\text { as } \mathrm{CaCO}_{3} \text { ) }\right.\end{array}$ & NLF & 1.0 & & & \\
\hline Chloride & NLF & $-^{c}$ & & & \\
\hline Chromium & NLF & 0.05 & & & \\
\hline Cobalt & NLF & 0.05 & & & \\
\hline Conductivity ( $\mu \mathrm{mhos} / \mathrm{cm})$ & NLF, FOS & $-^{c}$ & & & \\
\hline Copper & NLF & 0.05 & & & \\
\hline Filterable residue (TDS) & NLF, FOS & $-c$ & & & \\
\hline $\begin{array}{l}\text { Hydroxide alkalinity } \\
\left.\text { (as } \mathrm{CaCO}_{3}\right)\end{array}$ & NLF & 1 & & & \\
\hline Lead & NLF, TAR & 0.2 & & & \\
\hline Magnesium & NLF & 0.05 & & & \\
\hline Mercury & NLF & 0.0005 & & & \\
\hline Molybdenum & NLF & 0.2 & & & \\
\hline Nickel & NLF & 0.05 & & & \\
\hline Nitrate/Nitrite & NLF & $-^{c}$ & & & \\
\hline $\mathrm{pH}$ (units) & NLF, FOS & $-c$ & & & \\
\hline Potassium & NLF & 1.0 & & & \\
\hline Selenium & NLF & 0.002 & & & \\
\hline Silver & NLF & 0.05 & & & \\
\hline Sodium & NLF & $-^{c}$ & & & \\
\hline Sulfate & NLF & $-c$ & & & \\
\hline Thallium & NLF & 0.2 & & & \\
\hline Total alkalinity (as $\mathrm{CaCO}_{3}$ ) & NLF & $-^{c}$ & & & \\
\hline Vanadium & NLF & 0.05 & & & \\
\hline Zinc & NLF & 0.05 & & & \\
\hline $\begin{array}{l}\text { Volatile hydrocarbons (EPA } \\
\text { method } 8015 \text { ) }\end{array}$ & $\begin{array}{l}\text { NLF, ASL, } \\
\text { FOS, TAR }\end{array}$ & $\begin{array}{l}\text { Detection } \\
\text { limit } b\end{array}$ & & & \\
\hline $\begin{array}{l}\text { Halogenated and aromatic volatile } \\
\text { organics (EPA method } \\
601 / 602 \text { ) }\end{array}$ & $\begin{array}{l}\text { NLF, ASL, } \\
\text { FOS, TAR }\end{array}$ & $\begin{array}{l}\text { Detection } \\
\text { limit } b\end{array}$ & & & \\
\hline
\end{tabular}

aASL = Arroyo Seco Locations (wells AS3, AS4), FOS = Fuel Oil Spill Site, NLF = Navy Landfill Site, TAR = Trudell Auto Repair Shop Site bDetection limits can vary from sample to sample, depending on items suct, as matrix interference and instrument sensitivity.

cNot applicable. 


\section{Groundwater Protection Program}

Table7-2. Highest Positively Detected Parameters in SNL/CA Area Monitoring Wells,a

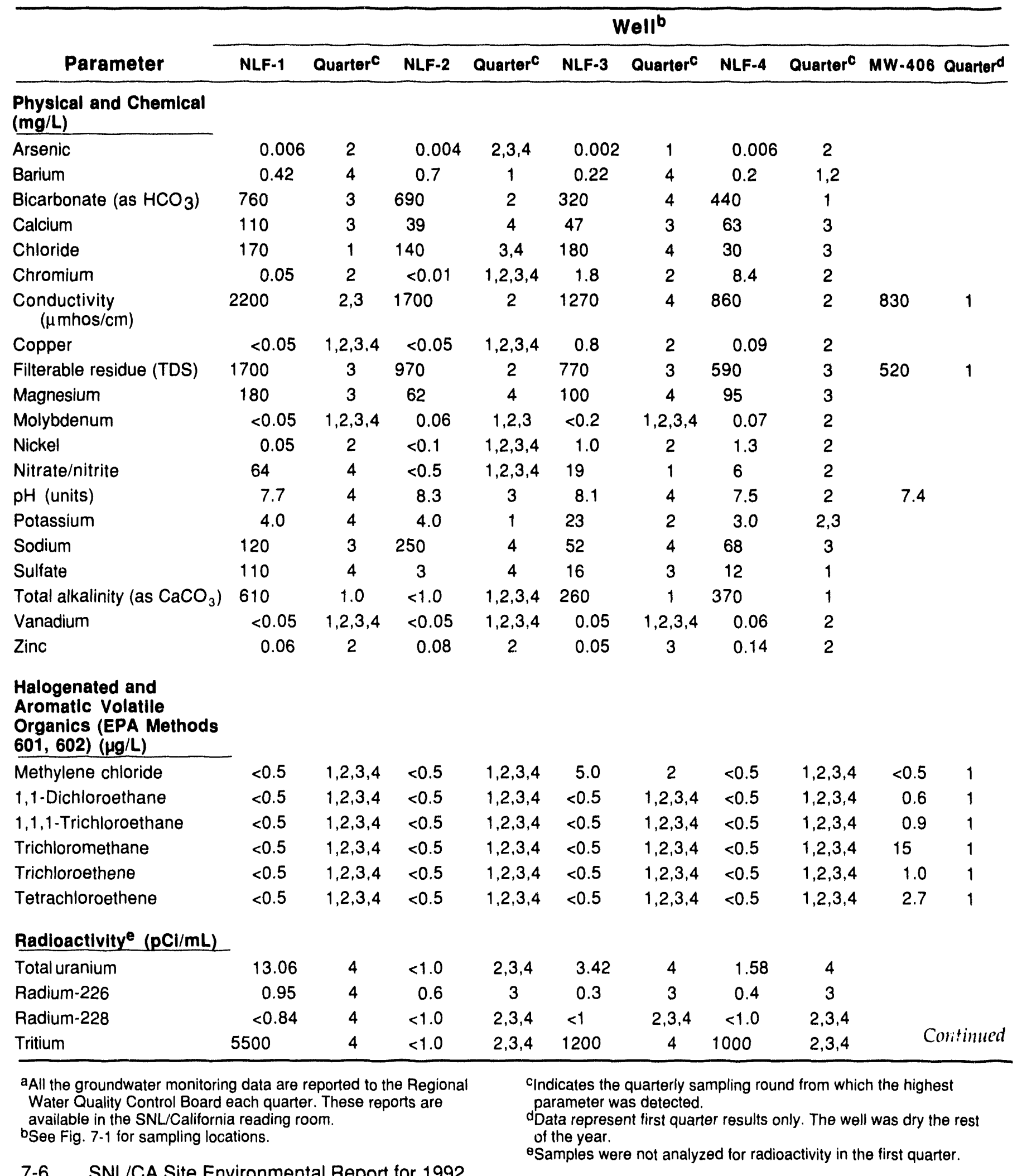




\section{Groundwater Protection Program}

\section{Table 7-2. Highest Positively Detected Parameters in SNL/California Area}

Monitoring Wells.

\begin{tabular}{|c|c|c|c|c|c|c|c|c|}
\hline \multirow[b]{2}{*}{ Parameter } & \multicolumn{8}{|c|}{ Wella } \\
\hline & FOS-19c & Quarter $^{d}$ & FOS-20 $c$ & Quarter ${ }^{d}$ & FOS $-21^{\circ}$ & Quarterd & FOS-22 & Quarter $^{d}$ \\
\hline \multicolumn{9}{|l|}{ Physical and Chemical } \\
\hline Conductivity ( $\mu \mathrm{mhos} / \mathrm{cm}$ ) & 540 & 1 & 1000 & 1 & 990 & 2 & 880 & 3 \\
\hline $\begin{array}{l}\text { Filterable residue (TDS) } \\
\text { (mg/L) }\end{array}$ & 540 & 1 & 670 & 1 & 600 & 1 & 520 & 3 \\
\hline $\mathrm{pH}$ (units) & 7.1 & 1 & 7.4 & 1 & 8.1 & 2 & 7.6 & 1 \\
\hline \multicolumn{9}{|c|}{$\begin{array}{l}\text { Halogenated and Aromatic } \\
\text { Volatile Organics (EPA } \\
\text { Methods 601, 602) }(\mu \mathrm{g} / \mathrm{L})\end{array}$} \\
\hline Methylene chloride & $>0.5$ & 1 & 5.0 & 1 & $>0.5$ & 1,2 & 5.0 & 3 \\
\hline \multicolumn{9}{|l|}{ Radioactivity (pCl/mL) } \\
\hline Total uranium & & & & & 3.12 & 2 & 1.34 & 3 \\
\hline Radium-226 & & & & & $<1.0$ & 2 & 0.7 & 3 \\
\hline Radium-228 & & & & & $<1.0$ & 2 & & 3 \\
\hline Tritium & & & & & 1000 & 2 & & 3 \\
\hline
\end{tabular}

aSee Fig. $7 \cdot 1$ for sampling locations.

Continued

bunless noted in the table, all other constituents were below detection limits

cData represents first quarter sampling results only. The well was dry during the remainder of the year.

Indicates the quarterly sampling round from which the highest parameter was detected.

eData represents first and second quarter sampling results only. The well was dry during the remainder of the year.

'Data represents first and third quarter sampling results only. The well was dry during the remainder of the year. 


\section{Groundwater Protection Program}

\section{Table 7-2. Highest Positively Detected Parameters in SNL/California}

Area Monitoring Wells (concluded). a

\begin{tabular}{|c|c|c|c|c|c|c|}
\hline \multirow[b]{2}{*}{ Parameter ${ }^{b}$} & \multicolumn{6}{|c|}{ Well } \\
\hline & $A S-3 B^{C}$ & Quarter $^{d}$ & AS-3C ${ }^{\circ}$ & Quarter $^{d}$ & AS4 $^{\prime}$ & Quarter \\
\hline \multicolumn{7}{|l|}{$\begin{array}{l}\text { Physical and Chemical } \\
\text { (mg/L) }\end{array}$} \\
\hline $\begin{array}{l}\text { Conductivity } \\
(\mu \mathrm{mhos} / \mathrm{cm})\end{array}$ & 2200 & 2,3 & 1700 & 2 & 1270 & 4 \\
\hline Copper & $<0.05$ & $i, 2,3,4$ & $<0.05$ & $1,2,3,4$ & 0.8 & 2 \\
\hline Filterable residue (TDS) & 1700 & 3 & 970 & 2 & 770 & 3 \\
\hline pH (units) & 7.7 & 4 & 8.3 & 3 & 8.1 & 4 \\
\hline \multicolumn{7}{|l|}{$\begin{array}{l}\text { Halogenated and Aro- } \\
\text { matic Volatile Organics } \\
\text { (EPA Methods 601, 602) } \\
\text { (Ppb) }\end{array}$} \\
\hline Methylene chloride & $<0.5$ & $1,2,3,4$ & $<0.5$ & $1,2,3,4$ & 5.0 & 2 \\
\hline \multicolumn{7}{|l|}{ Radioactivity (pCl/mL) } \\
\hline Total uranium & 13.06 & 4 & $<1.0$ & $2,3,4$ & 3.42 & 4 \\
\hline Radium-226 & 0.95 & 4 & 0.6 & 3 & 0.3 & 3 \\
\hline Radium-228 & $<0.84$ & 4 & $<1.0$ & $2,3,4$ & $<1$ & $2,3,4$ \\
\hline Tritium & 5.50 & 4 & $<1.0$ & $2,3,4$ & 1.2 & 4 \\
\hline
\end{tabular}

aSee Fig. 7-1 for sampling locations.

bunless noted in the table, all other constituents were below detection limits.

cData represents first and fourth quarter sampling results only. The well was dry during the remainder of the year.

$d$ Indicates the quarterly sampling round from which the highest parameter was detected.

eData represents first, second, and fourth quarter sampling results only. The well was dry during the remainder of the year.

tData represents first and second quarter sampling results only. The well was dry during the remainder of the year. 


\section{8 - Quality Assurance}

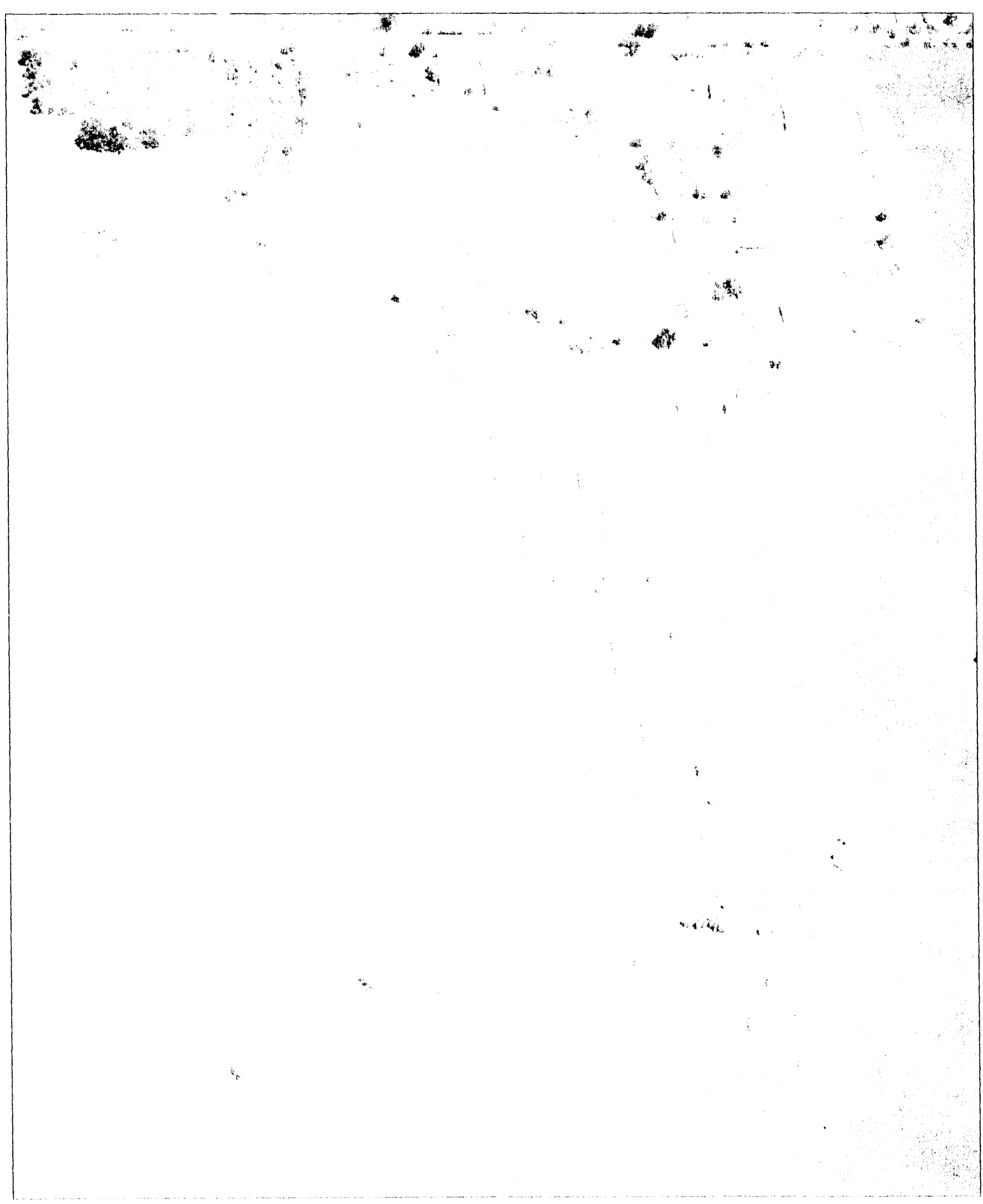




\section{Quality Assurance}

SNL/California maintains an effluent monitoring and environmental surveillance program, as required by DOE Orders 5400.1 and $5400.5 .5,3$ These Orders specify quality assurance requirements consistent with DOE Order 5700.6B. ${ }^{39}$ DOE has issued DOE Order 5700.6C,, 22 which supersedes DOE Order 5700.6B. The Center for ES\&H and Facilities at SNL/California has developed and is implementing a Quality Assurance Management Plan (QAMP) consistent with the provisions of DOE Order requirements. Additionally, provisions of the QAMP that are best implemented at a Center level are prescribed by approved procedures. These implementing procedures include the following:

- qualifications and training,

- procedure development and control,

- control of measuring and test equipment, including monitoring and data collection equipment,

- identification and control of samples,

- identification and control of technical data,

- procurement control,

- records management, and

- independent assessment.

Consistent with the requirements of the QAMP, the Environmental Monitoring Program group has developed a Quality Assurance Project Plan (QAPP), (Appendix E), which describes how the QAMP will be put into action. The QAPP includes quality assurance provisions from other pertinent documents, such as Title 40 CFR, Part 58, Ambient Air Quality Surveillance, ${ }^{40}$ and the EPA's Quality Assurance
Handbook for Air Pollution Measurement Systems. ${ }^{41}$ In order to meet the most current guidance on quality assurance for environmental projects, the QAPP follows the guidance and format of the draft Quality Assurance Requirements for Environmental Programs. ${ }^{42}$ Supplementing the QAPP and implementing provisions of the QAMP are operating procedures that detail environmental monitoring activities. Operating procedures specify requirements for monitoring, liquid effluent control system monitoring, annual off-site radiological dose assessments, and process wastewater sampling for compliance with Federal categorical pretreatment regulations.

Normal data and supervisory reviews are incorporated into the Environmental Monitoring Program. The QAMP provides for management assessments, which are done by upper management. Assessments identify problems that may keep the organization from achieving required goals or conforming to requirements. Finally, the QAMP provides for independent technical assessments to verify quality.

LLNL conducts much of the off-site environmental monitoring and transmits the results to SNL/California. LLNL has a QA program and procedures for environmental monitoring, documented in the Environmental Quality Verification Group's Quality Assurance Plan.43 Samples processed outside of LLNL are sent to laboratories that have been State-certified to do the analyses required. Many of the radiological analyses are done by the Nuclear Chemistry Division at LLNL. The Nuclear Chemistry Division has established a QA Plan for environmental measurement and has applied to the State for certification. 
State certification requires that $\mathrm{QC}$ samples be processed in the following proportions to routine samples: blanks-10\%, duplicates-10\%, spikes-10\%, and reference samples up to $10 \%$, as available. The data from these analyses are used to assess the accuracy and precision of the sampling and analyses. LLNL has set goals for the accuracy of sample collection and analysis at $\pm 20 \%$, and precision of the sampling and analysis at $\pm 30 \%$. Each year, the data from the QC samples are summarized in this report.

Table 8-1 shows the data from the collection of duplicate field samples. These data assess the precision of the entire sampling and analysis system. For media where fewer than eight duplicate samples were collected, the data is presented as a simple ratio of the result from the duplicate sample divided by the result from the routine sample. Where more than eight duplicate samples are available (storm-water runoff, rainwater, and milk), a regression analysis was performed on the data set in order to give more detailed information about the correlation between the duplicate and routine samples. In addition, the $95 \%$ confidence interval was computed for media with more than eight data pairs. The Environmental Quality Verification Group's Quality Assurance Plan ${ }^{43}$ contains the following acceptance criteria for these parameters:

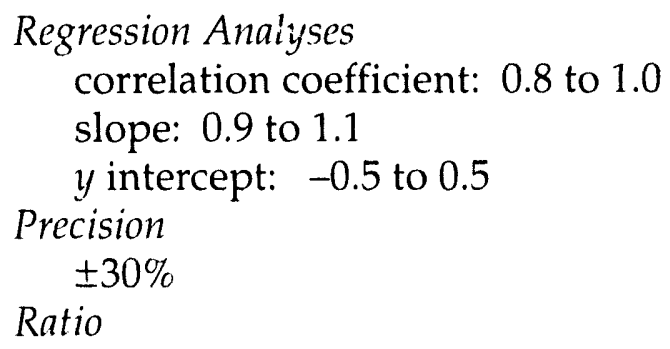

0.7 to 1.3
Table 8-1 shows that the regression analyses for tritium in rainwater and air do not meet the acceptance criteria. The results also show that the acceptance criteria for the $95 \%$ confidence interval are not met by any of the samples. To address these problems, LLNL has formed a team composed of Environmental Monitoring Section and Analytical Laboratory personnel. The same analyses of duplicate sample data are reported in the SNL/California Environmental Monitoring Plan ${ }^{4}$ but for a time period of several years. These analyses show that the precision of many sampling programs has failed to meet acceptance criteria for a number of years.

Table 8-2 shows the results of LLNL's participation in the EPA's Environmental Radioactivity Laboratory Intercomparison Studies Program. All results are within the acceptable range $( \pm 3$ normalized deviations), but the value of 2.49 falls within the "warning" region. An LLNL investigation indicates the problem probably stemmed from a turnover of laboratory personnel, and inexperienced personnel performing the analysis.

Table 8-3 shows the results of LLNL's participation in the DOE's Environmental Measurements Laboratory Quality Assessment Program. The sample ratio of 0.69 falls outside of the acceptance criteria of $\pm 20 \%$. This result is probably due to processing by an inexperienced analyst, as noted above. 


\section{Quality Assurance}

\section{Table 8-1. Quality Assurance-Duplicate Sampling, Selected Parameters.}

\begin{tabular}{|c|c|c|c|c|c|c|c|}
\hline \multirow[b]{2}{*}{ Medium } & \multirow[b]{2}{*}{ Parameter } & \multirow[b]{2}{*}{$\begin{array}{c}\text { Data Capture } \\
(\%)^{b}\end{array}$} & \multirow[b]{2}{*}{$\begin{array}{c}95 \% \text { Confidence } \\
\text { Intervalc }\end{array}$} & \multirow[b]{2}{*}{ Ratiod } & \multicolumn{3}{|c|}{ Regression Analysis ${ }^{a}$} \\
\hline & & & & & $\begin{array}{l}\text { Correlation } \\
\text { coefficient }\end{array}$ & Slope & $Y$-intercept \\
\hline \multicolumn{8}{|l|}{ Water } \\
\hline $\begin{array}{l}\text { Storm-water } \\
\text { runoff }\end{array}$ & ${ }^{3} \mathrm{H}$ & 100 & $-62 /+72$ & $-^{e}$ & 0.99 & 0.94 & 0.93 \\
\hline Rainwater & ${ }^{3} \mathrm{H}$ & 94 & $-96 /+131$ & - & 0.37 & 0.75 & 30.7 \\
\hline $\begin{array}{l}\text { Surface and } \\
\text { drinking } \\
\text { water }\end{array}$ & ${ }^{3} \mathrm{H}$ & 97 & -1 & 0.96 & $-f$ & $-f$ & -1 \\
\hline $\begin{array}{l}\text { Livermore } \\
\text { Valley well } \\
\text { water }\end{array}$ & ${ }^{3} \mathrm{H}$ & 100 & $-62 /+182$ & - ${ }^{\theta}$ & 0.99 & 2.37 & -252 \\
\hline Vegetation & ${ }^{3} \mathrm{H}$ & 90 & $-1404 / \pm 2231$ & - $^{e}$ & 0.99 & 1.06 & -3530 \\
\hline Air & ${ }^{3} \mathrm{H}$ & 97 & $-183 /+272$ & $-\theta$ & 0.66 & 0.87 & 0.007 \\
\hline
\end{tabular}

aOnly calculated for data sets with more than eight valid data pairs.

bRatio of samples collected for that medium to the number of samples scheduled to be collected.

cCalculated according to the methodology in Quality Assurance Handbook for Air Pollution Measurement Systems (EPA 1976) for data sets with more than eight valid data pairs.

dOnly used for data sets with less than eight valid data pairs. Value is ratio of QA sample/routine sample.

eNot calculated-more than eight valid data pairs available.

'Not calculated-less than eight valid data pairs available. 


\section{Quality Assurance}

Table 8-2. Quality Assurance Analyses for the Environmental Protection Agency's Environmental Radioactivity Laboratory Intercomparison Studies Program.a

\begin{tabular}{ccccc}
\hline & & \multicolumn{2}{c}{ Value Reported $(\mathrm{pCl} / \mathbf{L} \pm 1 \sigma)$} & \\
\cline { 2 - 4 } Analysis & Media & LLNL & Known & $\begin{array}{c}\text { Normallzed deviation } \\
\text { from the known value }\end{array}$ \\
\hline Tritium & Water & 7986 & 7904 & 0.18 \\
& & 218.7 & 2125 & 0.29 \\
& 6818 & 5962 & 2.49 \\
\hline
\end{tabular}

aAll data were provided by LLNL's Nuclear Chemistry Division.

b Acceptable deviations are between -2 and $2(-2<x<2)$.

Table 8-3. Quality Assurance for the Department of Energy Environmental Measurements Laboratory (EML) Quality Assessment Program.a

\begin{tabular}{ccccc}
\hline Analysis & Media & LLNL Value & EML Value & LLNL/EML Ratio \\
\hline${ }^{3} \mathrm{H}$ & Water & 1560 & 2270 & 0.69 \\
& & 1350 & 1180 & 1.14 \\
\hline
\end{tabular}

aAll data were provided by LLNL's Nuclear Chemistry Division.

${ }^{b}$ Acceptable ratios are between 0.7 and 1.3. 
1. State of California, California Administrative Code, Title 22, "California Domestic Water Quality and Monitoring Regulations" (1977).

2. U.S. Environmental Protection Agency (EPA), Title 40 CFR, Part 433, Metal Finishing Point Source Category (July 1983).

3. U.S. Department of Energy (DOE), Order 5400.5, Radiation Protection of the Public and the Environment (March 1988).

4. R. C. Holland, Environmental Monitoring Plan, Sandia National Laboratories/California, SAND91-8013 (1991).

5. U.S. DOE, Order 5400.1, General Environmental Protection Program (November 1988).

6. U.S. DOE, Environmental Regulatory Guide, EH/0173T (January 1992).

7. U.S. DOE, Order 5484.1, Chapter I, Environmental Protection, Safety, and Health Protection Information Reporting Requirements (1981).

8. U. S. DOE, Order 5400.4, Comprehensive Environmental Response, Compensation, and Liability Act (October 6, 1989).

9. State of California, San Francisco Bay Region, Regional Water Quality Control Board, Order 88-142 (September 21, 1988).

10. State of California, San Francisco Bay Region, Regional Water Quality Control Board, Order 89-184 (December 13, 1989).

11. U.S. DOE, Sandia National Laboratories, Livermore, Navy Landfill Solid Waste Water Quality Assessment Test Proposal (March 1989).
12. U.S. DOE, Reconnaissance Investigation Report for Sandia National Laboratories, Livermore Miscellaneous Sites, DOE/AL Environmental Restoration Program (August 1992).

13. U.S. DOE and University of California, Environmental Impact Statement and Environmental Impact Report for Continued Operation of Lawrence Livermore National Laboratory and Sandia National Laboratories, Livermore, DOE/EIS-0157 (February 1992).

14. State of California, Bay Area Air Quality Management District (BAAQMD), Rules and Regulations (January 1980).

15. U.S. EPA, Title 40 CFR, Part 61, National Emission Stanuards for Hazardous Air Pollutants (NESHAPS) (December 15, 1989).

16. U.S. EPA, Title 40 CFR, Part 403, Federal Wastewater Pretreatment Standards (July 1983).

17. U.S. EPA, Title 40 CFR, Parts 122-24, National Pollutant Discharge Elimination System (November 1990).

18. EOA, Inc., Storm Water Pollution Prevention Plan, Sandia National Laboratories, California (July 1993).

19. National Pollutant Discharge Elimination System General Permit for Storm Water Discharge Associated with Industrial Activities, California State Water Resources Control Board (September 17, 1992).

20. U.S. DOE, Order 5000.3B, Occurrence Reporting and Processing of Operations Information (May 1990). 


\section{References}

21. U.S. DOE, Order 5480.1B, Environment, Safety, and Health

Program for Department of Energy Operations (September 1986).

22. U.S. DOE, Order 5700.6C, Quality Assurance (August 1992).

23. U.S. DOE, Sandia National Laboratories, Livermore, Hazardous Waste Operation Plan (February 1989).

24. U.S. DOE, Sandia National Laboratories, Livermore, Quarterly Groundwater Investigation Reports (1992).

25. T. K. Devlin, "Tritium Monitoring at the Sandia Tritium Research Laboratory," in Behavior of Tritium in the Environment (International Atomic Energy Agency, IAEA-SM-232/56, 1979).

26. D. D. Brekke, Semiannual Categorical Process Report, Sandia National Laboratories, Livermore (August and December 1992).

27. G. M. Gallegos et al., Environmental Report for 1992, Lawrence Livermore National Laboratory, UCRL-50027-92 (1992).

28. U.S. Nucleary Regulatory

Commission, Regulatory Guide 4.13, Performance Testing and Process Specifications for Thermoluminescent Dosimetry, Environmental Applications, Revision 1 (July 1977).

29. U.S. National Council on Radiological Protection and Measurement (NCRP), Ionizing Radiation Exposure of the Population of the United States, Report \#93 (NCRP 1987a).
30. U.S. NCRP, Exposure of the U.S. Population from Diagnostic Medical Radiation, Report \#96 (NCRP, 1989).

31. U.S. DOE, Albuquerque Operations Office, Navy Landfill Solid Waste Water Assessment Test Report (June 1990).

32. U.S. DOE, Sandia National Laboratories, Livermore, Stage 2 Remedial Investigation Plan, Sandia National Laboratories, Livermore; Trudell Auto Repair Shop (January 1989).

33. U.S. DOE, Sandia National Laboratories, Livermore, Trudell Auto Repair Shop Sampling Plan (1989).

34. State of California, Title $23 \mathrm{CCR}$, Chapter 3, Subchapter 16, "Underground Storage Tank Regulations" (1986).

35. U.S. DOE, Sandia National Laboratories, Livermore, Spill Prevention Control and Countermeasure Plan (December 1992).

36. U.S. EPA, Title 40 CFR, Part 112, Oil Pollution Prevention (December 1973).

37. DOE Order 5820.2A, Decommissioning of Radioactively Contaminated Facilities (September 1988).

38. U.S. DOE, Sandia National Laboratories, Livermore, Groundwater Protection Management Program Plan (September 1990).

39. U.S. DOE, Order 5700.6B, Quality Assurance (March 1989).

40. U.S. EPA, Title 40 CFR, Part 58, Ambient Air Quality Surveillance (1987). 
41. U.S. EPA, Quality Assurance Handbook for Air Pollution Measurement Systems, EPA600/9-76-005 (1976).

42. American Society for Quality Control, Quality Assurance Requirements for Environmental Programs, ANSI/ASQC E4 (September 1992).

43. R. C. Holland, Environmental Quality Verification Group, Quality Assuiance Plan, Lawrence Livermore National Laboratory, UCAR-10203 (September 1987).

In addition to the above references, the following bibliographic entries were used for background information in preparing this report:

U.S. EPA, Title 40 CFR, Part 265, Interim Status Standards for Owners and Operators of Hazardous Waste Treatment, Storage, and Disposal Facilities (July 1989).

U.S. EPA, National Interim Primary Drinking Water Regulations, EPA570/9-76-003 (1977).

U.S. DOE, Internal Dose Conversion Factors for Calculation of Dose to the Public, EH-0071 (1988).

U.S. DOE, External Dose-Rate Conversion Factors for Calculation of Dose to the Public, EH-0071 (1988).

U.S. DOE Notice of Intent, Federal Register, 55 FR 41048.

U.S. DOE, Order 5400.6, Radiological Effluent Monitoring and Environmental Surveillance (December 1990).

U.S. EPA, Test Methods for Evaluating Solid Waste: Laboratory Manual Physical/Chemical Methods, SW-846 (November 1986).
U.S. DOE, Order 5482.1B, AL Environment, Safety, and Health (ESEH) Appraisal Program (April 1984).

U.S. DOE, Sandia National Laboratories, Livermore, ESEH Self-Assessment Program, Issue B, PG470093.

J. D. Watkins, Secretary of Energy, Guidance on ESEH Self-Assessment, S-1 (July 31, 1990).

D. D. Brekke and R. C. Holland, Environmental Monitoring at the Lawrence Livermore National Laboratory, Annual Report 1988, Lawrence Livermore National Laboratory, UCRL-50027-88 (1989).

T. K. Devlin, Ground Water Protection Program Actions and Investigations, Sandia National Laboratories, Livermore, Report to the California Regional Water Quality Control Board (April 1986).

T. K. Devlin, Preoperational Environmental Monitoring Report for the SNLL Tritium Research Laboratory, Sandia National Laboratories, Livermore, SAND76-8033 (July 1976).

W. M. Lowder and H. L. Beck, "Cosmic Ray Ionization in the Lower Atmosphere," J. Geo. Phys. Rev. 71:4611 (1966).

U.S. Nuclear Regulatory Commission, Regulatory Guide 1.109, Calculation of Annual Doses to Man from Routine Releases of Reactor Effluent for the Purpose of Evaluation Compliance with 10 CFR Part 50, Appendix 1 (1977). 
Glossary

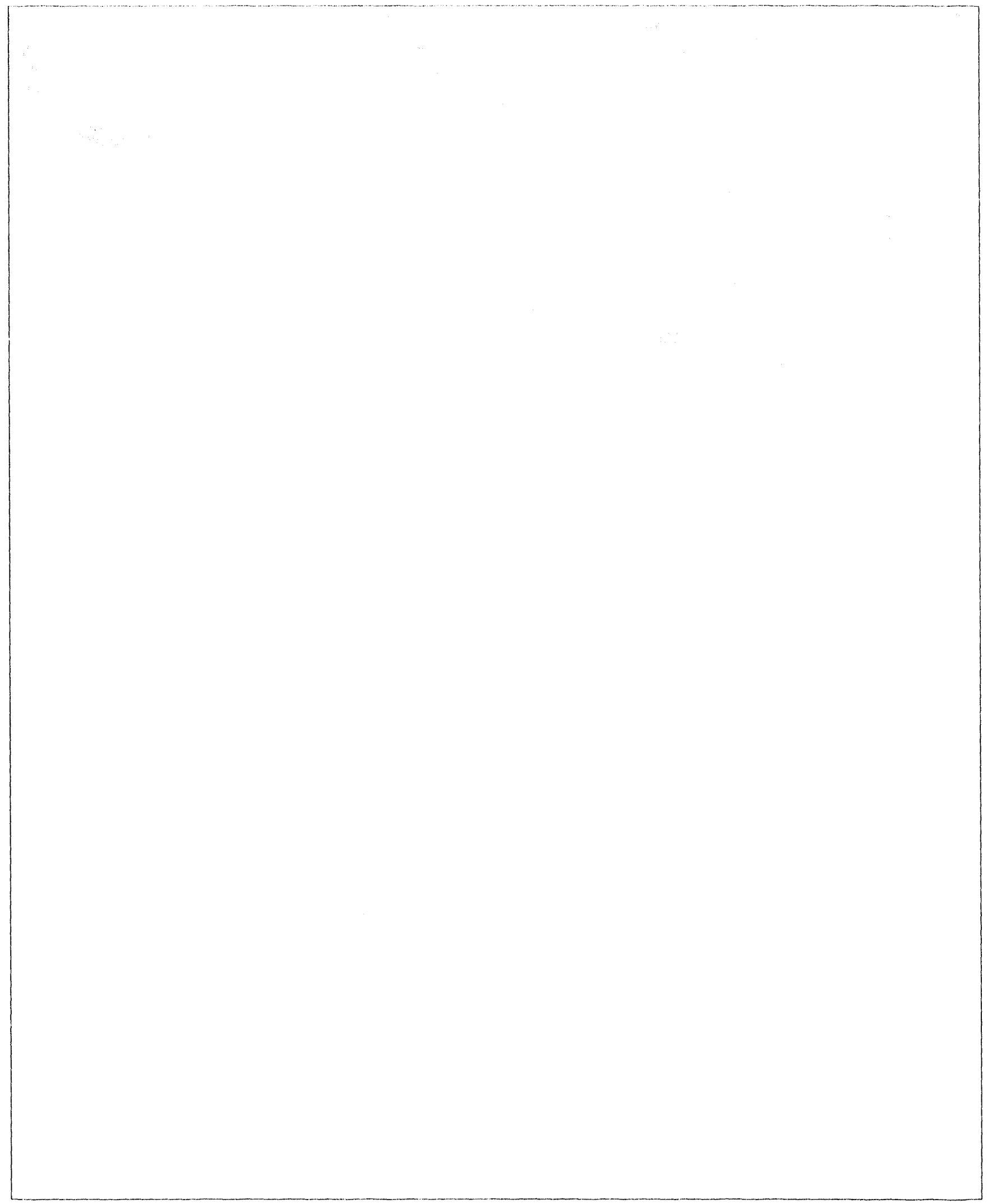




\section{ACronyms and AbBreviations}

$\begin{array}{ll}\text { ADM } & \text { Action Description Memorandum } \\ \text { AIP } & \text { Agreement in Principle (DOE and California) } \\ \text { ALARA } & \text { as low as reasonably achievable } \\ \text { ANSI } & \text { American National Standards Institute } \\ \text { ARAC } & \text { Atmospheric Release Advisory Capability } \\ \text { ARB } & \text { California Air Resources Board } \\ \text { ASME } & \text { American Society of Mechanical Engineers } \\ \text { BAAQMD } & \text { Bay Area Air Quality Management District } \\ \text { BAT } & \text { best available control technology } \\ \text { BOD } & \text { biological oxygen demand } \\ \text { CAA } & \text { Clean Air Act (Federal) } \\ \text { CAAC } & \text { Clean Air Act Code (EPA) } \\ \text { Cal/EPA } & \text { California Environmental Protection Agency } \\ \text { CCR } & \text { California Code of Regulations } \\ \text { CEARP } & \text { Comprehensive Environmental Assessment and Response Program } \\ \text { CEQA } & \text { California Environmental Quality Act } \\ \text { CERCLA } & \text { Comprehensive Environmental Response, Compensation, and } \\ & \text { Liability Act } \\ \text { CFR } & \text { Code of Federal Regulations } \\ \text { COD } & \text { chemical oxygen demand } \\ \text { COE } & \text { (Army) Corps of Engineers } \\ \text { CWA } & \text { Clean Water Act (Federal) } \\ \text { DCG } & \text { Derived Concentration Guide (DOE) } \\ \text { DHS } & \text { Department of Health Services (California) } \\ \text { DL } & \text { discharge limit (City of Livermore) } \\ \text { DOE } & \text { Department of Energy } \\ \text { DOE/AL } & \text { Department of Energy/Albuquerque Operations Office } \\ \text { DOE/SAN } & \text { Department of Energy/San Francisco Operations Office } \\ \text { DOL } & \text { Department of Labor } \\ \text { DTSC } & \text { Department of Toxic Substances Control (California) } \\ \text { DWS } & \text { drinking water standard } \\ \text { EA } & \text { Environmental Assessment } \\ \text { EDE } & \text { effective dose equivalent } \\ \text { EIR } & \text { Environmental Impact Report } \\ \text { EIS } & \text { Environmental Impact Statement } \\ \text { EMG } & \text { Environmental Monitoring Group (LLNL) } \\ & \end{array}$




\section{Glossary}

$\begin{array}{ll}\text { EML } & \text { Environmental Monitoring Laboratory (DOE) } \\ \text { EMSL } & \text { Environmental Measurements and Standards Laboratory (EPA) } \\ \text { EPA } & \text { Environmental Protection Agency } \\ \text { EPCRA } & \text { Emergency Planning and Community Right-to-Know Act } \\ \text { ES\&H } & \text { environment, safety and health } \\ \text { ESA } & \text { Endangered Species Act } \\ \text { FIFRA } & \text { Federal Insecticide, Fungicide, and Rodenticide Act } \\ \text { FS } & \text { Feasibility Study } \\ \text { GPS } & \text { Gas Purification System } \\ \text { GWPMPP } & \text { Groundwater Protection Management Program Plan } \\ \text { HT or T } 2 & \text { elemental tritium } \\ \text { HTO or } T_{2} O & \text { tritium oxide (tritiated water) } \\ \text { ICRP } & \text { International Commission on Radiological Protection } \\ \text { IMTL } & \text { Integrated Manufacturing Technologies Laboratory } \\ \text { IRM } & \text { Intermediate Remedial Measure } \\ \text { KAO } & \text { Kirtland Area Office (DOE Albuquerque Operations Office) } \\ \text { LAP } & \text { Laboratory Assessment Program } \\ \text { LECS } & \text { Liquid Effluent Control System } \\ \text { LLNL } & \text { Lawrence Livermore National Laboratory } \\ \text { LWRP } & \text { Livermore Water Reclamation Plant } \\ \text { MAD } & \text { median absolute deviation } \\ \text { MCL } & \text { maximum contaminant level } \\ \text { MSDS } & \text { Material Safety Data Sheet } \\ \text { NAAQS } & \text { National Ambient Air Quality Standards } \\ \text { NEPA } & \text { National Environmental Policy Act } \\ \text { NESHAPs } & \text { National Emission Standards for Hazardous Air Pollutants } \\ \text { NHPA } & \text { National Historic Preservation Act } \\ \text { NIST } & \text { National Institute of Standards and Technology } \\ \text { NOD } & \text { Notice of Deficiency } \\ \text { NOV } & \text { Notice of Violation } \\ \text { NPDES } & \text { National Pollutant Discharge Elimination System } \\ \text { NPL } & \text { National Priority List } \\ \text { NQA } & \text { Nuclear Quality Assurance } \\ \text { NRC } & \text { Nuclear Regulatory Commission } \\ \text { NTS } & \text { Nevada Test Site } \\ \text { NVO } & \text { Nevada Operations Office (DOE) } \\ & \end{array}$




$\begin{array}{ll}\text { OFCCP } & \text { Office of Federal Contract Compliance Program } \\ \text { ORS } & \text { Occurrence Reporting System } \\ \text { OSHA } & \text { Occupational Safety and Health Administration } \\ \text { OSP } & \text { Operational Surety Program } \\ \text { OSRs } & \text { Operational Safety Requirements } \\ \text { PCB } & \text { polychlorinated biphenyl } \\ \text { POTW } & \text { publicly-owned treatment works } \\ \text { PWA } & \text { Process Waste Assessment } \\ \text { QA } & \text { quality assurance } \\ \text { QAMP } & \text { Quality Assurance Management Plan } \\ \text { QAPP } & \text { Quality Assurance Project Plan } \\ \text { QC } & \text { quality control } \\ \text { RAP } & \text { Remedial Action Plan } \\ \text { RCRA } & \text { Resource Conservation and Recovery Act } \\ \text { RI } & \text { Remedial Investigation } \\ \text { RWQCB } & \text { Regional Water Quality Control Board } \\ \text { SARA } & \text { Superfund Amendments and Reathorization Act } \\ \text { SDM } & \text { standard deviation of the mean } \\ \text { SDWA } & \text { Safe Drinking Water Act } \\ \text { SNL } & \text { Sandia National Laboratories } \\ \text { SOP } & \text { Standard Operating Procedure } \\ \text { SWAT } & \text { Solid Waste Water Quality Assessment Test } \\ \text { SWRCB } & \text { State Water Resources Control Board } \\ \text { TDS } & \text { total dissolved solids } \\ \text { TLD } & \text { thermoluminescent dosimeter } \\ \text { TRL } & \text { Tritium Research Laboratory } \\ \text { TSCA } & \text { Toxic Substance Control Act } \\ \text { TSDF } & \text { treatment, storage, and disposal facility } \\ \text { TSS } & \text { total suspended solids } \\ \text { TTO } & \text { total toxic organics } \\ \text { UST } & \text { underground storage tank } \\ \text { VERS } & \text { Vacuum Effluent Recovery System } \\ \text { VOC } & \text { volatile organic compound } \\ \text { WM\&PPAP } & \text { Waste Minimization and Pollution Prevention Awareness Program } \\ & \end{array}$




\section{TECHNICAL TERMS}

accuracy

air particulates

aliquot

alpha particle

ambient air

aquifer

arroyo

background radiation

beta particle

categorical process

collective effective dose equivalent

contaminant

controlled area
The closeness of the result of a measurement to the true value of the quantity measured.

Airborne particles. These may include dust, dirt, and pollutants that occur as particles, and any pollutants that may be associated with or carried on the dust or dirt.

A portion of a sample taken for analysis.

A charged particle (identical to the helium nucleus) comprising two protons and two neutrons that are emitted during decay of certain radioactive atoms. Alpha particles are stopped by several centimeters of air or a sheet of paper.

The surrounding atmosphere, usually the outside air, as it exists around people, plants, and structures. It does not include the air next to emission sources.

A saturated iayer of rock or soil below the ground surface that can supply usable quantities of ground water to wells and springs. Aquifers can be a source of water for domestic, agricultural, and industrial uses.

An intermittent or seasonal stream.

Ionizing radiation from sources other than the Laboratories. This background may include cosmic radiation; external radiation from naturally occurring radioactivity in the earth (terrestrial radiation), air, and water; internal radiation from naturally occurring radioactive elements in the human body; and radiation from medical diagnostic procedures.

A charged particle (identical to the electron) that is emitted during decay of certain radioactive atoms. Most beta particles are stopped by $\leq 0.6 \mathrm{~cm}$ of aluminum.

An industrial process governed by Federal regulations of wastewater discharges.

The sum of the effective dose equivalents of all individuals in an exposed population within a certain radius; expressed in units of person-rem (or person-sievert).

Any hazardous or radioactive material present in an environmental medium, such as water or vegetation.

Any Laboratory area to which access is controlled to protect individuals from exposure to radiation and radioactive materia's. 
cosmic radiation

discharge

dose, absorbed

dose, effective

dose, maximum boundary

dose, maximum individual

dose, population

dosimeter
High-energy particulate and electromagnetic radiation that originates outside the earth's atmosphere. Cosmic radiation is part of natural background radiation.

A release into an area not controlled by SNL/California.

A term denoting the quantity of radiation energy absorbed.

The energy imparted to matter by ionizing radiation per unit mass of irradiated material. (The unit of absorbed dose is the rad.)

The hypothetical whole-body dose that would give the same risk of cancer mortality and/or serious genetic disorder as a given exposure and that may be limited to just a few organs. The effective dose equivalent is equal to the sum of individual organ doses, each weighted by degree of risk that the organ dose carries. For example, a 100-mrem dose to the lung, which has a weighting factor of 0.12 , gives an effective dose that is equivalent to 12 mrem $(100 \times 0.12)$.

dose, equivalent A term used in radiation protection that expresses all types of radiation (alpha, beta, and so on) on a common scale for calculating the effective absorbed dose. It is the product of the absorbed dose in rads and certain modifying factors. (The unit of dose equivalent is the rem.)

The greatest dose commitment, considering all potential routes of exposure from a facility's operation, to a hypothetical individual who is in an uncontrolled area where the highest dose rate occurs. It assumes that the hypothetical individual is present $100 \%$ of the time (full occupancy), and it does not take into account shielding (for example, by buildings).

The greatest dose commitment, considering all potential routes of exposure from a faciliiy's operation, to an individual at or outside the Laboratory boundary where the highest dose rate occurs. It takes into account shielding and occupancy factors that would apply to a real individual.

The sum of the radiation doses to individuals of a population. It is expressed in units of person-rem. For example, if 1000 people each received a radiation dose of $1 \mathrm{rem}$, their population dose would be 1000 person-rem.

A portable detection device for measuring the total accumulated exposure to ionizing radiation. See also thermoluminescent dosimeter. 
downgradient

effective dose equivalent

effluent

emission

environmental remediation

exposure

external radiation

extractable

pollutants

gamma radiation

groundwater

half-life, radioactive

hazardous waste
In the direction of groundwater flow from a designated area of interest; analogous to downstream.

Abbreviated EDE; the summation of the products of the dose equivalent received by specified tissues of the body and a tissuespecific weighting factor. This sum is a risk-equivalent value and can be used to estimate the health risk of the exposed individual. The tissue-specific weighting factor represents the fraction of the total health risk resulting from uniform whole-body irradiation that would be contributed by that particular tissue. The EDE includes the committed EDE from internal deposition of radionuclides and the EDE due to penetrating radiation from sources external to the body; it is expressed in units of rem (or sievert).

A liquid or gaseous waste discharged to the environment.

A gaseous or liquid stream containing one or more contaminants. The verb form, emit, means the act of discharging a contaminant or pollutant into the environment.

The process of restoring a contaminated area to a noncontaminated or safe condition.

A measure of the ionization produced in air by $x$ or gamma radiation. (The unit of exposure is the roentgen.)

Radiation originating from a source outside the body.

Pollutants that can be removed from a contaminated sample by passing water through the sample.

Short-wavelength electromagnetic radiation of nuclear origin that has no mass or charge. Because of its short wavelength (high energy), gamma radiation can cause ionization. Other electromagnetic radiation (such as microwaves, visible light, and radio waves) have longer wavelengths (lower energy) and cannot cause ionization.

A subsurface body of water in the zone of saturation (where soil sediments have become saturated with water).

The time required for the activity of a radioactive substance to decrease to half its value by inherent radioactive decay. After two half-lives, one-fourth of the original activity remains $(1 / 2 \times 1 / 2)$; after three half-lives, one-eighth $(1 / 2 \times 1 / 2 \times 1 / 2)$; and so on.

Waste exhibiting any of the following characteristics: ignitability, corrosivity, reactivity, or EP-toxicity (yielding toxic constituents in a leaching test). Because of its concentration, quantity, physical, or chemical characteristics, it may: 1) cause or significantly contribute 
internal radiation

lysimeter

nonattainment area

nuclide

organic compound

organochloride

Part B permit

$\mathrm{pH}$

piezometer

pollutant

pretreatment

pretreatment regulations to an increase in mortality rates or cases of serious irreversible illness; or 2) pose a substantial present or potential threat to human health or the environment when improperly treated, stored, transported, disposed of, or handled.

Radiation from a source within the body as a result of deposition of radionuclides in body tissues by processes such as ingestion, inhalation, or implantation. Potassium $\left({ }^{40} \mathrm{~K}\right)$, a naturally occurring radionuclide, is a major source of internal radiation in living organisms.

A device for sampling soil moisture in the unsaturated zone. See vadose zone.

An area that does not meet the National Ambient Air Quality Standards.

A species of atom characterized by what constitutes the nucleus, which is specified by the number of protons, number of neutrons, and energy content; or, alternatively, by the atomic number, mass number, and atomic mass. To be regarded as a distinct nuclide, the atom must be able to exist for a measurable length of time.

A chemical whose primary constituents are carbon and hydrogen.

An organic compound in which one or more of the hydrogen atoms have been replaced with a chlorine atom.

The second, narrative section submitted by generators in the RCRA permitting process. It details the procedures followed at a facility to protect human health and the environment.

A measure of hydrogen ion concentration in an aqueous solution. Acidic solutions have a $\mathrm{pH}$ less than 7 , basic solutions have a $\mathrm{pH}$ greater than 7, and neutral solutions have a $\mathrm{pH}$ of 7 .

Generally, a small-diameter, nonpumping well used to measure the elevation of the water table or potentiometric surface (an imaginary surface that represents the static head of groundwater and is defined by the level to which water will rise).

Any hazardous or radioactive material present in an environmental medium, such as water or vegetation.

Any process used to reduce a pollutant load before wastewater enters the sewer system.

National wastewater pretreatment regulations (40 CFR 403) adopted by the EPA in compliance with the 1977 amendmt nts to the Clean Water Act, which required that the EPA establish pretreatment standards for existing and new industrial sources. 


\section{Glossary}

priority pollutants

purgeable pollutants

radiation protection standard

radiation

radioactivity

radiological

radionuclide

recharge zone

remediation

scintillation cocktail

source

terrestrial

terrestrial radiation

thermoluminescent dosimeter (TLD)

tritium

uncontrolled area
A set of organic and inorganic chemicals identified by the EPA as indicators of environmental contamination.

Pollutants that can be removed from a sample by passing nitrogen gas through the sample.

Limits on radiation exposure regarded as necessary for protection of public health. These standards are derived based on acceptable levels of risk to individuals.

Energy emitted from the nucleus of an atom in the form of waves or particles.

The property or characteristic of a nucleus of an atom to spontaneously disintegrate accompanied by the emission of energy in the form of radiation.

Arising from radiation or radioactive materials.

An unstable nuclide. See nuclide and radioactivity.

An area of the ground in which surface water migrates to the groundwater.

See environmental remediation.

A solution of organic compounds that emits light upon inceracting with radiation. For the purposes of this report, it is used primarily for the analysis of tritium.

Any operation or equipment that produces and/or emits pollutants (e.g., pipe, ditch, well, or stack).

Pertaining to or deriving from the earth.

Radiation emitted by naturally occurring radionuclides, such as ${ }^{40} \mathrm{~K}$; the natural decay chains ${ }^{235} \mathrm{U}$, ${ }^{238} \mathrm{U}$, or ${ }^{2.22} \mathrm{Th}$; or cosmic-rayinduced radionuclides in the soil.

A type of dosimeter. After being exposed to radiation, the material in the dosimeter (lithium fluoride) luminesces upon being heated. The amount of light the material emits is proportional to the amount of radiation (dose) to which it was exposed. See also dosimeter.

A radionuclide of hydrogen with a half-life of 12.3 years. The very low energy of its radioactivity decay makes it one of the least hazardous radionuclides.

An area beyond the boundaries of a controlled area. See controlled area. 
upgradient

uranium

uranium, depleted

uranium, total

vadose zone

wind rose

Zone 7

\section{RADIOLOGICAL UNITS}

becquerel (Bq)

curie (Ci)

mrem

person-rem
Opposite of the direction of groundwater flow from a designated area of interest. Analogous to upstream.

A metallic element that is highly toxic and radioactive.

Uranium consisting primarily of $238 \mathrm{U}$ and having less than $0.72 \mathrm{wt} \%{ }^{235} \mathrm{U}$. Except in rare cases occurring in nature, depleted uranium is man-made.

The amount of uranium in a sample, assuming that the uranium has the isotopic content of uranium in nature $(99.27 \mathrm{wt} \% 238 \mathrm{U}$, $0.72 \mathrm{wt} \%$ 235U, and $0.0057 \mathrm{wt} \% 234 \mathrm{U}$ ).

The partially saturated or unsaturated region of the ground above the water table that does not yield water to wells.

A diagram that shows the frequency and intensity of wind from different directions at a particular place.

The common name for the Alameda County Flood Control and Water Conservation District. Zone 7 is the water management agency for the Livermore-Amador Valley with responsibility for water treatment and distribution. Zone 7 is also responsible for management of agricultural and surface water and the groundwater basin.

Unit of radioactive decay equal to one disintegration per second. (SI unit)

Unit of radioactive decay equal to $2.22 \times 10^{12}$ disintegrations per minute. (conventional units)

millirem $\left(10^{-3}\right.$ rem $)$. See rem.

The unit of population dose, which expresses the sum of radiation exposures received by a population. For example, two persons, each with a 0.5 -rem exposure, receive 1 person-rem, and 500 people, each with an exposure of 0.002 rem, also receive 1 personrem.

A unit of absorbed dose from ionizing radiation ( $0.877 \mathrm{rad} / \mathrm{R})$.

Stands for roentgen equivalent man; a unit of ionizing radiation, equal to the amount of radiation needed to produce the same biological effect to humans as $1 \mathrm{rad}$ of high-voltage $x$-rays. It is the product of the absorbed dose ( $\mathrm{rad}$ ), quality factor $(\mathrm{Q})$, distribution factor, and other necessary modifying factors. It describes the effectiveness of various types of radiation in producing biological effects. 


\section{Glossary}

roentgen $(R)$

A unit of radiation exposure that expresses exposure in terms of the amount of ionization produced by $x$ or gamma rays in a volume of air. One roentgen (R) is $2.58 \times 10^{-4}$ coulombs per kilogram of air.

sievert (Sv)

A unit of radiation dose equivalent. The Sv is the SI unit equivalent to the rem. It is the product of the absorbed dose (gray), quality factor $(\mathrm{Q})$, distribution factor, and other necessary modifying factors. It describes the effectiveness of various types of radiation to produce biological effects; $1 \mathrm{~Sv}=\mathrm{Gy} \times \mathrm{Q} \times \mathrm{N}=100 \mathrm{rem}$.

\section{UNITS OF MEASURE}

Throughout this report, an attempt has been made to incorporate the International System of Units-Systeme Internationale (SI) or metric system of measurements, with some exception. Radiological quantities (activity - curies (Ci), exposure-roentgen ( $R$ ), and dose-rad and $\mathrm{rem}$ ] have also been reported in U.S. conventional units because current standards are written in terms of these units. The equivalent SI units are the becquerel $(\mathrm{Bq})$, coulomb per kilogram $(\mathrm{C} / \mathrm{kg})$, gray $(\mathrm{Gy})$, and sievert $(\mathrm{Sv})$, respectively.

Table G-1 presents prefixes used in this report to define fractions or multiples of the base units of measurement. Table G-2 lists abbreviations for commonly used units of measure. Table G-3 presents conversion factors for converting from SI units to U.S. conventional units. 
Table G-1. Prefixes Used with SI (Metric) Units.

\begin{tabular}{llc}
\hline Prefix & \multicolumn{1}{c}{ Factor } & Symbol \\
\hline mega & 1000 o00 or $10^{9}$ & $\mathrm{M}$ \\
kilo & 1000 or $10^{3}$ & $\mathrm{k}$ \\
centi & 0.01 or $10^{-2}$ & $\mathrm{c}$ \\
milli & 0.001 or $10^{-3}$ & $\mathrm{~m}$ \\
micro & 0.000001 or $10^{-6}$ & $\mathrm{\mu}$ \\
nano & 0.000000001 or $10^{-9}$ & $\mathrm{n}$ \\
pico & 0.000000000001 or $10^{-12}$ & $\mathrm{P}$ \\
femto & 0.000000000000001 or $10^{-15}$ & $\mathrm{f}$ \\
atto & 0.000000000000000001 or $10^{-18}$ & $\mathrm{a}$ \\
\hline
\end{tabular}

Table G-2. Abbreviations for Commonly Used Units of Measure.

\begin{tabular}{lll}
\hline & Symbol & \multicolumn{1}{c}{ Name } \\
\hline Radioactivity & $\mathrm{Ci}$ & Curie \\
& $\mu \mathrm{Ci}$ & microcurie $\left(10^{-6} \mathrm{Ci}\right)$ \\
& $\mathrm{Bq}$ & becquerel \\
Volume & $\mathrm{cm}^{3}$ & cubic centimeter \\
& $\mathrm{L}$ & liter \\
& $\mathrm{mL}$ & milliliter $\left(10^{-3} \mathrm{~L}\right)$ \\
& $\mathrm{m}^{3}$ & cubic meter \\
& $\mathrm{ppmv}$ & parts per million volume \\
& $\mathrm{ppb}$ & parts per billion \\
& $\mu \mathrm{L}$ & microliter $\left(10^{-6} \mathrm{~L}\right)$ \\
& $\mathrm{km}$ & \\
& $\mathrm{m}$ & kilometer $\left(10^{3} \mathrm{~m}\right)$ \\
& $\mathrm{cm}$ & meter $(\mathrm{m})$ \\
& $\mathrm{mm}$ & centimeter $\left(10^{-2} \mathrm{~m}\right)$ \\
& $\mu \mathrm{m}$ & millimeter $\left(10^{-3} \mathrm{~m}\right)$ \\
& $\mathrm{kg}$ & micrometer $\left(10^{-6} \mathrm{~m}\right)$ \\
& $\mathrm{g}$ & kilogram $\left(10^{3} \mathrm{~g}\right)$ \\
& $\mathrm{mg}$ & gram \\
& $\mu \mathrm{g}$ & milligram $\left(10^{-3} \mathrm{~g}\right)$ \\
& $\mathrm{yr}$ & microgram $\left(10^{-6} \mathrm{~g}\right)$ \\
& $\mathrm{d}$ & year \\
& $\mathrm{h}$ & day \\
& & hour \\
& & minute \\
\hline
\end{tabular}




\section{Glossary}

\section{Table G-3. Conversion Factors for Selected SI (Metric) Units.}

\begin{tabular}{|c|c|c|}
\hline Multiply SI Unit & By & $\begin{array}{c}\text { To Obtain } \\
\text { IJ.S. Conventional Unit }\end{array}$ \\
\hline $\begin{array}{l}\text { Celsius }\left({ }^{\circ} \mathrm{C}\right) \\
\text { centimeters }(\mathrm{cm})\end{array}$ & $\begin{array}{c}9 / 5, \text { then add } 32 \\
0.39\end{array}$ & $\begin{array}{l}\text { Fahrenheit ( }{ }^{\circ} F \text { ) } \\
\text { inches (in.) }\end{array}$ \\
\hline cubic meters $\left(\mathrm{m}^{3}\right)$ & 35 & cubic feet $\left(\mathrm{ft} .^{3}\right)$ \\
\hline hectares (ha) & 2.5 & acres \\
\hline grams $(g)$ & 0.035 & ounces (oz.) \\
\hline kilograms (kg) & 2.2 & pounds ( $\mathrm{lb}$. ) \\
\hline kilometers (km) & 0.62 & miles (mi.) \\
\hline liters $(L)$ & 0.26 & gallons (gal.) \\
\hline meters $(m)$ & 3.3 & feet (ft.) \\
\hline micrograms per gram $(\mu \mathrm{g} / \mathrm{g})$ & 1 & parts per million (ppm) \\
\hline milligrams per liter (mg/L) & 1 & parts per million (ppm) \\
\hline square kilometers $\left(\mathrm{km}^{2}\right)$ & 0.39 & square miles $\left(\mathrm{mi}^{2}{ }^{2}\right)$ \\
\hline becquerel $(\mathrm{Bq})$ & $2.7 \times 10^{-11}$ & curie (Ci) \\
\hline gray (Gy) & 100 & $\mathrm{rad}$ \\
\hline sievert (Sv) & 100 & rem \\
\hline
\end{tabular}

GLS-12 SNL/CA Site Environmental Report for 1992 
Glossary

\begin{tabular}{|c|c|}
\hline Designator & Description \\
\hline $\begin{array}{l}\text { ALAG } \\
\text { ALTA }\end{array}$ & $\begin{array}{l}\text { Arroyo de la Laguna } \\
\text { Residence on Altamont Pass Road }\end{array}$ \\
\hline AQUE & Intersection of the California Aqueduct and Greenville Road \\
\hline AS3 & Arroyo Seco, downgradient wells \\
\hline AS4 & Arroyo Seco, upgradient well \\
\hline ASS & Arroyo Seco South, outfall from SNL/California \\
\hline BELL & Tapwater, Bell Ave., Livermore \\
\hline BVA & Buena Vista Avenue \\
\hline CAFE & LLNL south cafeteria \\
\hline CAL & Calaveras Reservoir \\
\hline CART & Purchased, cartoned, goat's milk \\
\hline DEL & Lake Del Valle \\
\hline DUCK & Springtown duck pond \\
\hline $\mathrm{ERCH}$ & Escobar ranch \\
\hline FCC & Federal Communications Commission office \\
\hline FIRE & Fire station on East Ave., Livermore \\
\hline FOS & Fuel Oil Spill \\
\hline GAS & Tapwater from gasoline station downtown Livermore \\
\hline HOSP & Veteran's Administration Hospital \\
\hline 1580 & Interstate 580 overpass over Greenville Road \\
\hline LCCY & Livermore City Corporation Yard \\
\hline LUP & Ranch on Lupin Way \\
\hline MET & LLNL Meteorological Tower \\
\hline MOD & Ranch in Modesto \\
\hline$M W-406$ & Monitoring Well \#406, old Trudell property \\
\hline MZF & Muzalski ranch \\
\hline NLF & Navy Landfill \\
\hline $\mathrm{ORCH}$ & Well water from orchard on Mines Road \\
\hline PALM & Tapwater, Palm Ave., Livermore \\
\hline PARK & Camp Parks, Army Reserve Training Center \\
\hline PATT & Residence on Patterson Pass Road \\
\hline POOL & LLNL swimming pool \\
\hline RAIL & Railroad tracks north of LLNL \\
\hline $\mathrm{RRCH}$ & Ralph ranch \\
\hline SALV & LLNL salvage yard \\
\hline SHAD & Shadow Cliffs Regional Park Recreation Area \\
\hline TANK & Water storage tanks on southern portion of SNL/California site \\
\hline TAP & LLNL tapwater \\
\hline TESW & Corner of Tesla Road and Mines Road \\
\hline TUR & Ranch in Turlock \\
\hline VET & Veterinarian's residence/business on Vasco Road \\
\hline VINE & Vineyard on Mines Road \\
\hline VIS & LLNL visitor's center \\
\hline WRD & Wardlaw ranch \\
\hline XRDS & Residence on Cross Road \\
\hline ZON7 & Patterson Pass water treatment facility of Zone 7 Water District \\
\hline
\end{tabular}




\section{Appendix A - Laboratory Procedures}

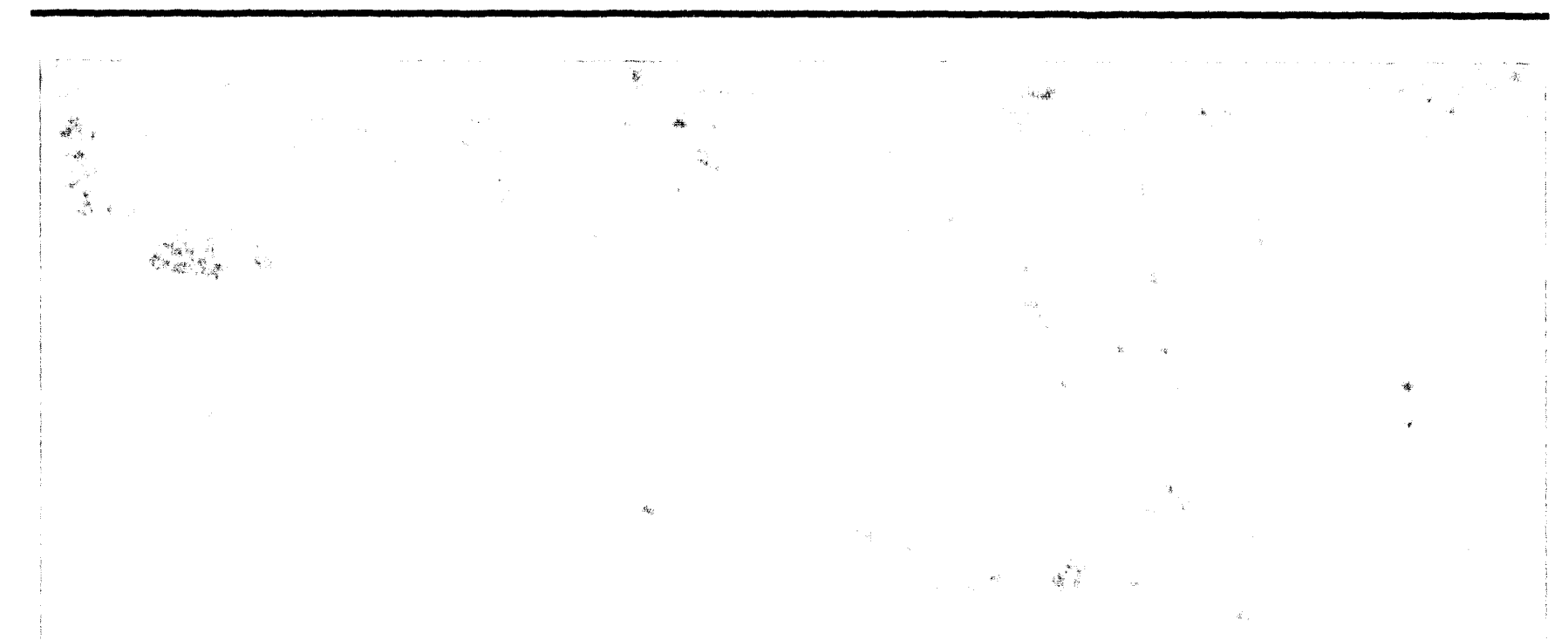

Ambient Air

External Radiation Stormwater Runoff

Soil/Sediment

Surface Water

Liquid Effluent Control Systems (LECS) 


\section{Laboratory Procedures}

SNL/California uses the Environmental Monitoring Laboratory (EML) of LLNL's Nuclear Chemistry Division for the analysis of radionuclides in environmental media (except gross alpha, gross beta, and tritium in groundwater, and gross alpha and gross beta in air particulates, which analyses are done by a commercial laboratory). The EML is obtaining State DHS laboratory accreditation. This process includes extensive documentation and implementation of personnel qualifications, analytical procedures, and quality assurance and quality control programs. The EML issued a quality assurance plan in April 1991. Submittal of the application for DHS accreditation is planned for 1992 pending complete implementation of the quality assurance and quality control programs.

Chemical and physical analyses on LECS samples are done by Environmental Protection Department personnel using equipment owned and maintained by LLNL's Inorganic and Physical Chemistry Department and SNL/California's Environmental Protection Department. These analyses, which are only indicative and not done for compliance purposes, are primarily for the presence of metals. Plans to add total organic carbon (TOC) analysis are in process.

Analyses of groundwater and gross alpha and gross beta in air particulates is performed by outside commercial laboratories. For a commercial laboratory to be considered for use by SNL/Californi, it must be DHS-accredited.

Following is a brief synopsis of the analyses done on samples from each of the environmental media.

\section{AMBIEnt AlR}

\section{Air Particulates}

One-half of the filter is submitted to the commercial laboratory for gross alpha and gross beta analyses. After a four-day waiting period (to allow decay of radon daughter products), a 2 -in. circle is cut from the filter and placed in a gas-proportional counter for determining gross alpha and beta activity. The other half of the filter is retained and included in a monthly composite sent to EML for uranium analyses. The filters are ashed, and then dissolved by treatment with $\mathrm{HF}, \mathrm{HClO}_{4}$, and $\mathrm{HNO}_{3}$. The uranium is then purified by ion exchange, and the activity of each of the uranium isotopes is determined by mass spectrometry.

\section{Tritium}

The silica gel is sent to EML, where it is transferred from the collection flask to a plastic bag. It is thoroughly mixed, and an aliquot is taken for processing. The sample is then freeze-dried. The water removed is counted by liquid scintillation to determine the tritium concentration.

The air tritium monitors maintained by SNL/California collect tritium by adsorption of water vapor onto ethylene glycol. The first three collection vessels collect the tritiated water vapor. The sample is then passed over a precious metal catalyst to convert the gaseous form (HT) into water vapor, which is then collected in the second three collection vessels. An aliquot of this ethylene glycol is then counted by liquid scintillation to determine the tritium concentration. 


\section{Laboratory Procedures}

\section{External Radiation}

The TLDs collected by LLNL are processed by LLNL's Hazards Control Department, using automated equipment. The TLDs are received from the Monitoring Group and stored in a lead shield until they are processed.

The TLDs collected by SNL/California personnel are processed by the Health Instrumentation Department at SNL/New Mexico. These TLDs are also stored in a lead shield before processing.

\section{Stormwater Runoff}

\section{Tritium}

The tritium samples are sent to EML, where they are prepared for counting by distillation under an argon atmosphere. After distillation, an aliquot is taken for liquid scintillation counting.

\section{Other Analyses}

The metals and organics samples are sent to a state-certified, commercial laboratory, where they are processed in accordance with EPA protocols. The analyses performed on stormwater runoff samples are EPA method 624 (volatile organics), EPA method 625 (nonvolatile organics), CCR Title 22 organics, metals (As, Ba, Be, Cd, Cr, $\mathrm{Pb}, \mathrm{Hg}, \mathrm{Se}, \mathrm{Ag}$ ), oil and grease, $\mathrm{COD}$, total organic carbon (TOC), $\mathrm{NO}_{3}, \mathrm{~F}^{-}$, gross alpha, gross beta, and tritium.

\section{SOIL/SEDIMENT}

\section{Tritium in Arroyo sediment}

A portion of the sediment is sent to EML, where it is freeze-dried. The water removed is then analyzed for tritium activity by liquid scintillation counting.

\section{Surface Soils}

The surface soil samples are sent to EML, where they are analyzed for various radioactive constituents. The only parameter of concern to SNL/California is urani$\mathrm{um}$, which is determined by gamma spectrometry.

\section{Other Analyses in Arroyo Sediments}

The metals and organics samples are sent to a certified commercial laboratory, where they are processed in accordance with EPA protocols. The analyses performed on sediment samples are EPA method 8(20), EPA method 8080, and metals (As, Ba, Be, Cd, $\mathrm{Cr}, \mathrm{Pb}, \mathrm{Hg}, \mathrm{Se}, \mathrm{Ag}$ ).

\section{Vegetation and Foodstuff}

All vegetation and foodstuff samples are processed by the EML.

\section{Tritium in Vegetation}

An aliquot of the vegetation is freeze-dried, and the water removed is analyzed for tritium activity by liquid scintillation counting.

\section{Tritium in Milk}

An aliquot of milk is freeze-dried, and the water removed is analyzed for tritium activity by liquid scintillation counting.

\section{Tritium in Wine}

An aliquot of wine is passed through a Peterson furnace to oxidize all the organic matter in the wine to water. This water is then passed through a gas conversion furnace, which converts the water to hydrogen gas. The hydrogen gas is then analyzed for tritium activity by introducing it into an 


\section{Laboratory Procedures}

internal gas proportional counter.

Alternatively, the wine may be purged with an inert gas and allowed to decay for a period of time. Then the ${ }^{3} \mathrm{He}$ (the decay product of tritium) is measured by mass spectrometry and used to calculate the tritium concentration.

\section{Tritium in Honey}

An aliquot of honey is placed into a Parr bomb. The sample is burned, converting the organic matter into water. This water is then passed through a gas conversion furnace, which converts the water to hydrogen gas. The hydrogen gas is then analyzed for tritium activity by introducing it into an internal gas proportional counter.

\section{Surface Water}

These samples are processed by the EML.

\section{Low-tritium Water}

Water that is expected to have very low tritium content (such as certain surface water, and well water) is processed by electrolytically concentrating the tritium content of the water (enriching). The water is then analyzed for tritium activity by liquid scintillation counting.

\section{High-tritium Water}

Because this water contains higher levels of tritium, electrolytic enrichment is not necessary. This water is distilled under an argon atmosphere and then is analyzed for tritium content by liquid scintillation.

\section{Groundwater}

Groundwater samples are collected by the certified commercial laboratory that ana- lyzes them. The samples are processed in accordance with EPA protocols. The analyses performed on ground water samples are EPA method 624 (volatile organics), EPA method 625 (non-volatile organics), CCR Title 22 organics, metals (As, Ba, Be, Cd, Cr, $\mathrm{Pb}, \mathrm{Se}, \mathrm{Ag}$ ), gross alpha, gross beta, and tritium.

\section{Liquid Effluent Control Systems (LECS)}

\section{Metals}

Metals analyses are performed by ICP-AES in accordance with internal Environmental Protection Department procedures, which are compatible with applicable EPA procedures.

\section{pH}

Analyses are performed in accordance with internal Environmental Protection Department procedures, which are compatible with applicable EPA procedures. 


\section{Appendix B - Summary of Wastewater Discharge Regulations}

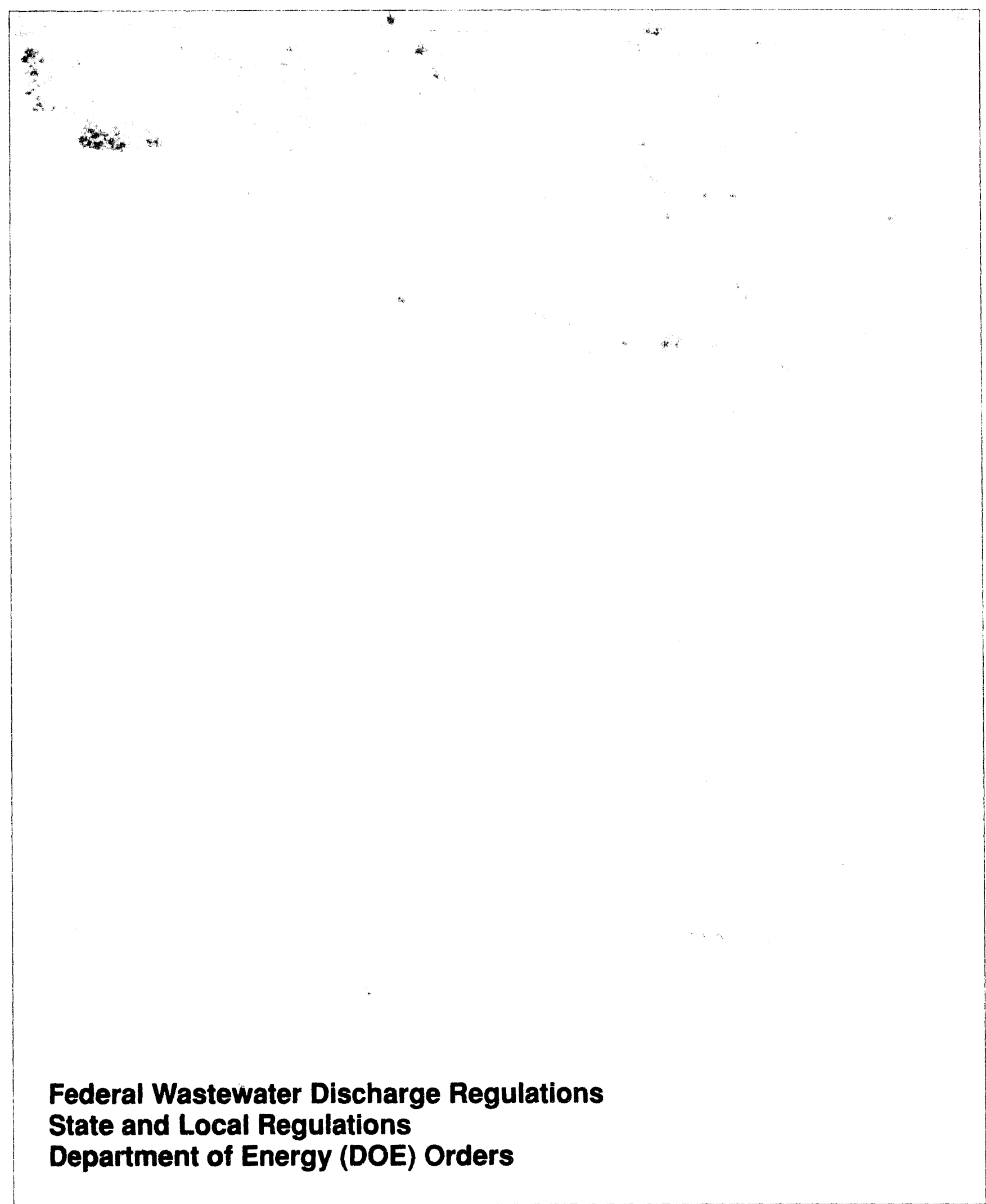




\section{Summary of Wastewater Discharge Regulations}

Because the wastewater discharge regulations that apply to SNL/California are extensive, this appendix provides a synopsis of pertinent laws and associated requirements. Three categories of regulations are discussed: Federal regulations, State and local regulations, and DOE Orders.

\section{Federal Wastewater Discharge REgUL_ATIONS}

The Clean Water Act provides the legislative framework for protecting the nation's waterways. Liquid discharges into surface waters and municipal sewer systems from industrial sources are regulated. In accordance with the objectives of the Clean Water Act, the EPA has established categorical pretreatment standards for specified classes of industrial dischargers. SNL/California is designated as a "Metal Finishing Point Source Category." Therefore, SNL/California is subject to the pretreatment standards in Title 40 CFR, Parts 403 and 433 . These standards are based on available pollution control technology for specific industrial processes.

The Metal Finishing Category covers wastewater discharges from 46 unit operations (Table B-1). SNL/California currently operates two processes subject to the Federal Pretreatment Standards: The Electroplating Laboratory in Bldg. 913 and the Printed Wiring Facility in Bldg. 910. Many of these unit operations are common throughout the site (e.g., welding, soldering, grinding, etc.), but are not subject to pretreatment standards, because they do not generate a continual, uncontained liquid effluent.
The major provisions of the Federal Pretreatment Standards applicable to Sandia are the wastewater discharge prohibitions (Title 40 CFR, Part 433), summarized in Table B-2. The discharge limits apply at the point of discharge from the designated process, before any dilution occurs.

Table B-3 lists the toxic organic compounds that make up the total toxic organic (TTO) standard for Metal Finishing Categories (Title 40 CFR, Part 433.11). This list is consistent with the City of Livermore's definition of TTO, which includes all EPA priority organic pollutants. The TTO standard is defined as the summation of all quantifiable values greater than $10 \mu \mathrm{g} / \mathrm{L}$ of these compounds.

\section{State And Local Regulations State of California}

The EPA has delegated authority to the State of California to enforce the National Pollutant Discharge Elimination System (NPDES) and Federal Categorical Pretreatment Standards (Title 40 CFR, Part 403). The San Francisco Bay Regional Water Quality Control Board (RWQCB) has issued an NPDES permit to the City of Livermore Water Reclamation Plant (LWRP). In addition, the Federal pretreatment program is administered through the LWRP with oversight by the RWQCB. This arrangement ensures a viable pretreatment program and enforcement of all pertinent State and Federal regulations.

Title 22 of the California Code of Regulations (CCR) defines hazardous waste. The criteria for hazardous waste are applicable regardless of waste origin. If wastewater meets the Federal or State 


\section{Summary of Wastewater Discharge Regulations}

criteria of a hazardous waste (and is not otherwise covered under the Clean Water Act), it may not be discharged to the sewer system.

Title 17 CCR, Section 30287, states that the total quantity of radionuclides released from a facility to a public sanitary sewer system shall not exceed $1 \mathrm{Ci}$ per year.

\section{City of Livermore}

Section 13.32 of the City of Livermore Municipal Code contains the discharge limits for Livermore's sanitary sewer system. These limits are stated in Sandia's Wastewater Discharge Permit, issued annually by the LWRP, and summarized below.

In general, no facility may discharge any pollutant or wastewater that will interfere with the operation or performance of the publicly-owned treatment works (POTW). Users of the POTW shall not discharge to the sanitary sewer system the following substances:

(a) Any liquids, solids, or gases that by reason of their nature or quantity are, or may be, sufficient either alone or by interaction with other substances to cause fire or explosion or be injurious in any other way to the POTW or to the operation of the POTW.

(b) Solid or viscous substances that may cause obstruction to the flow in a sewer or other interference with the operation of the wastewater treatment facilities.

(c) Any wastewater having a $\mathrm{pH}$ less than 6 or greater than 9 , unless a city permit is obtained. Wastewater having any other corrosive property capable of causing damage or hazard to structures, equipment, and/or personnel of the POTW is also prohibited.

(d) Any wastewater containing toxic pollutants in sufficient quantity, either singly or by interaction with other pollutants, to injure or interfere with any wastewater treatment process, constitute a hazard to humans or animals, or create a toxic effect in the receiving waters of the POTW.

(e) Any noxious or malodorous liquids, gases, or solids, which either singly or by interaction with other wastes, are sufficient to create a public nuisance or hazard to life or are sufficient to prevent entry into the sewers for maintenance and repair.

(f) Any substances that may cause the POTW effluent or any other product of the POTW, such as residues, sludges, scums, or gases, to be unsuitable for reclamation and reuse or to interfere with the reclamation process.

(g) Any waters or waste that contain more than $100 \mathrm{mg} / \mathrm{L}$ of freon, extractable fat, oil, or grease.

(h) Any substance that will cause the POTW to violate its NPDES Permit or the receiving water quality standards.

(i) Any wastewater with objectionable color not removed in the treatment process. 


\section{Summary of WastewaterDischarge Regulations}

(j) Any wastewater having a temperature that will inhibit biological activity in the POTW treatment plant.

(k) Any pollutants, including oxygendemanding pollutants (BOD) released at a flow rate and/or pollutant concentration that a user knows or has reason to know will cause interference to the POTW.

(l) Any wastewater containing any radioactive wastes or isotopes of such half-life or concentration as may exceed the limits established by the State or Federal regulatory agency applicable to the POTW user.

(m) Any wastewater that causes a hazard to human life or creates a public nuisance.

(n) Any waters or wastes containing total dissolved solids increment greater than $325 \mathrm{mg} / \mathrm{L}$, or chloride increment greater than $75 \mathrm{mg} / \mathrm{L}$.

(o) Any water or waste having BOD greater than 300 (the average $B O D$ for residential users), unless a city permit is obtained.

(p) Any waters or wastes containing more than $300 \mathrm{mg} / \mathrm{L}$ of suspended solids.

Specifically, SNL/California shall not discharge wastewater containing pollutant concentrations (measured at the site outfall) greater than those listed in Table B-4.

\section{DePARTMENT OF ENERGy (DOE) ORDERS}

The principal DOE Order governing discharges to public sewer systems is DOE Order 5400.5, Radiation Protection of the Public and the Environment. The purpose of this order is to establish standards and requirements for DOE operations to protect members of the public and the environment against undue risk from radiation. The DOE Orders only address radiation protection, e.g., radionuclide discharges to public sewer systems.

If liquid effluents discharged from DOE operations into sanitary sewer systems contain radionuclides at average monthly concentrations greater than five times the Derived Concentration Guide (DCG) values for liquids (Chapter III of Order 5400.5) at the point of discharge, then Best Available Control Technology (BAT) shall be implemented.

Tritium is the only radionuclide routinely discharged to the sanitary sewer from operations on the Sandia/California site. Applying the discharge limit for tritium, the monthly average tritium concentration in the sanitary sewer effluent from the site may not exceed $0.01 \mu \mathrm{Ci} / \mathrm{mL}$.

Additional DOE Order 5400.5 requirements for controlling radionuclide discharges are listed below.

1. Discharges to public sewers should be coordinated with the operators of the wastewater treatment works.

2. Concentrations shall be controlled so that long-term buildup of radionuclides 


\section{Summary of Wastewater Discharge Regulations}

in solids will not present a handling and disposal problem at sewage disposal plants.

3. If liquid effluents contain concentrations greater than five times the DCG value, ALARA process considerations are required.

4. Operators should ensure that the total annual discharge of radioactive material to the sanitary sewer system will not cause exposures to members of the general public that will result in doses exceeding a small fraction of the basic annual dose limit. 


\section{Summary of Wastewater Discharge Regulations}

\section{Table B-1. The 46 EPA-designated Metal-finishing Unit Operations.}

\begin{tabular}{|c|c|c|c|c|c|}
\hline 1. & Electroplating & 17. & Thermal cutting & 32. & Hot dip coating \\
\hline 2. & Electroless plating & 18. & Welding & 33. & Sputtering \\
\hline 3. & Anodizing & 19. & Brazing & 34. & Vapor plating \\
\hline 4. & Conversion coating & 20. & Soldering & 35. & Thermal infusion \\
\hline 5. & Etching (chemical milling) & 21. & Flame spraying & 36. & Salt bath descaling \\
\hline 6. & Printed circuit board mfg. & 22. & Sand blasting & 37. & Solvent degreasing \\
\hline 7. & Cleaning & 23. & Other abrasive jet machining & 38. & Paint stripping \\
\hline 8. & Machining & 24. & Electronic discharge machining & 39. & Painting \\
\hline 9. & Grinding & 25. & Electrochemical machining & 40 & Electrostatic painting \\
\hline 10. & Polishing & 26. & Electron beam machining & 41. & Electropainting \\
\hline 11. & Barrel finishing (tumbling) & 27. & Laser beam machining & 42. & Vacuum metallizing \\
\hline 12. & Burnishing & 28. & Plasma arc machining & 43. & Assembly \\
\hline 13. & Impact deformation & 29. & Ultrasonic machining & 44. & Calibration \\
\hline 14. & Pressure deformation & 30. & Sintering & 45. & Testing \\
\hline 15. & Shearing & 31. & Laminating & 46. & Mechanical plating \\
\hline 16. & Heat treating & & & & \\
\hline
\end{tabular}

Table B-2. Pretreatment Standards for Metal Finishing Category.a

\begin{tabular}{|c|c|c|}
\hline Pollutant & Daily Maximum (mg/L) & $\begin{array}{l}\text { Maximum Monthly Average } \\
(\mathrm{mg} / \mathrm{L})^{\mathrm{c}}\end{array}$ \\
\hline Cadmium $(T)^{d}$ & 0.69 & 0.26 \\
\hline Chromium $(T)$ & 2.77 & 1.71 \\
\hline Copper (T) & 3.38 & 2.07 \\
\hline Lead $(T)$ & 0.69 & 0.43 \\
\hline $\operatorname{Nickel}(\mathrm{T})$ & 3.98 & 3.28 \\
\hline Silver $(T)$ & 0.43 & 0.24 \\
\hline $\operatorname{Zinc}(T)$ & 2.61 & 1.48 \\
\hline Cyanide $(T)$ & 1.20 & 0.65 \\
\hline Total Toxic Organics & 2.13 & - \\
\hline Cyanide, amenable to chlorination & 0.86 & 0.32 \\
\hline
\end{tabular}

aThis refers to pretreatment standards for existing sources. Pretreatment standards for new sources (PSNS) apply to metal finishing operations that began operation after August 31, 1982. Some of the new source standards are more stringent.

bThe daily maximum limit should be applied to batch discharges.

cThe maximum monthly average is statistically based on ten samples per month.

d" $T$ " indicates total. 


\section{Summary of Wastewater Discharge Regulations}

Table B-3. Regulated Toxic Organics.

\begin{tabular}{|c|c|c|}
\hline Acenaphthene & 2,4-dimethylphenol & 11,12-benzofluoranthene \\
\hline Acrolein & 2,4-dinitrotoluene & Chrysene \\
\hline Acrylonitrile & 2,6-dinitrotoluene & Acenaphthylene \\
\hline $\begin{array}{l}\text { Benzene } \\
\text { Benzidine }\end{array}$ & $\begin{array}{l}\text { 1,2-diphenylhydrazine } \\
\text { (tetrachloromethane) }\end{array}$ & $\begin{array}{l}\text { Anthracene } \\
\text { 1,12-benzoperylene }\end{array}$ \\
\hline Carbon tetrachloride & Ethylbenzene & Fluorene \\
\hline Chlorobenzene & Fluoranthene & Phenanthrene \\
\hline 1,2,4-trichlorobenzene & 4-chlorophenyl phenyl ether & 1,2,5,6-dibenzanthracene \\
\hline Hexachlorobenzene & 4-bromophenyl phenyl ether & Indeno $(1,2,3-\mathrm{cd})$ pyrene \\
\hline 1,2-dichloroethane & Bis (2-chloroisopropyl) ether & Pyrene \\
\hline 1,1,1-trichloroethane & Bis (2-chloroethoxy) methane & Tetrachloroethylene \\
\hline Hexachloroethane & Methylene chloride (dichloromethane) & Toluene \\
\hline 1,1-dichloroethane & Methylchloride (chloromethane) & Trichloroethylene \\
\hline 1,1,2-trichloroethane & Methyl bromide (bromomethane) & Vinyl chloride (chlorethylene) \\
\hline 1,1,2,2-tetrachloroethane & Bromoform (tribromomethane) & 3,3-dichlorobenzidine \\
\hline Chloroethane & Dichlorobromomethane & 1,1-dichloroethylene \\
\hline Bis (2-chloroethyl) ether & Chlorobibromomethane & 1,2-trans-dichloroethylene \\
\hline 2-chloroethyl vinyl ether (mixed) & Hexachlorobutadiene & (TCDD) \\
\hline 2-chloronaphthalene & Hexachlorocyclopentadiene & Endosulfan sulfate \\
\hline $2,4,6$-trichlorophenol & Isophorone & Endrin (benzo(b)fluorantherne) \\
\hline Parachlorometa cresol & Naphthalene & Endrin aldehyde (benzo(k)fluorantheme) \\
\hline Chloroform (trichloromethane) & Nitrobenzene & Heptachlor \\
\hline $\begin{array}{l}\text { 2-chlorophenol } \\
\text { 1,2-dichlorobenzene }\end{array}$ & $\begin{array}{l}\text { 2-nitrophenol } \\
\text { 4-nitrophenol }\end{array}$ & $\begin{array}{l}\text { Heptachlor epoxide (BHB- } \\
\text { hexachlorocyclohexane) }\end{array}$ \\
\hline 1,3-dichlorobenzene & 2,4-dinitrophenol & Alpha-BHC \\
\hline 1,4-dichlorobenzene & 4,6-dinitro-o-cresol & Beta-BHC (benzo(ghi)perylene) \\
\hline $\mathrm{N}$-nitrosodi-n-propylamine & $\mathrm{N}$-nitrosodinethylamine & Gamma-BHC \\
\hline Pentachlorophenol & $\mathrm{N}$-nitrosodiphenylamine & Delta-BHC \\
\hline $\begin{array}{l}\text { Phenol } \\
\text { Bis (2-ethylhexyl) phthalate }\end{array}$ & $\begin{array}{l}\text { Aldrin } \\
\text { Dieldrin }\end{array}$ & $\begin{array}{l}\text { PCB-polychlorinated biphenyls } \\
\text { (dibenzo(a,h)antracene) }\end{array}$ \\
\hline $\begin{array}{l}\text { Butyl benzyl phthalate } \\
\text { Di-n-butyl phthalate }\end{array}$ & Chlordane & $\begin{array}{l}\text { PCB-1242 (Arochlor 1242) (2,3-0- } \\
\text { phenlene pyrene) }\end{array}$ \\
\hline Di-n-octyl phthalate & 4,4-DDT & PCB-1254 (Arochlor 1254) \\
\hline Diethyl phthalate & 4,4-DDE (p,p-DDX) & PCB-1221 (Arochlor 1221) \\
\hline Dimethyl phthalate & 4,4-DDD (p,p-TDE) & PCB-1232 (Arochlor 1232) \\
\hline $\begin{array}{l}\text { 1,2-benzanthracene } \\
\text { (benzo(a)anthracene) }\end{array}$ & $\begin{array}{l}\text { Alpha-endosulfan } \\
\text { Beta-endosulfan }\end{array}$ & $\begin{array}{l}\text { PCB-1248 (Arochlor 1248) } \\
\text { PCB-1260 (Arochlor 1260) }\end{array}$ \\
\hline 2,4-dichlorophenol & Benso(a)pyrene (3,4-benzopyrene) & PCB-1016 (Arochlor 1016) \\
\hline $\begin{array}{l}\text { 1,2-dichloropropane (1,3 } \\
\text { dichloropropene) }\end{array}$ & 3,4-benzofluoranthene & $\begin{array}{l}\text { Toxaphene } \\
2,3,7,8 \text {-tetrachlorodibenzo-p-dioxin }\end{array}$ \\
\hline
\end{tabular}

B-6 SNL/CA Site Environmental Report for 1992 


\section{Summary of Wastewater Discharge Regulations}

Table B-4. Specific Pollutant Limitations for Wastewater Discharged to the Livermore Water Reclamation Plant.

\begin{tabular}{lc}
\hline \multicolumn{1}{c}{ Pollutant } & $\begin{array}{c}\text { Discharge Concentration } \\
(\mathrm{mg} / \mathrm{L})\end{array}$ \\
\hline Arsenic & 0.06 \\
Cadmium & 0.14 \\
Copper & 1.0 \\
Cyanide & 0.04 \\
Lead & 0.2 \\
Mercury & 0.01 \\
Nickel & 0.61 \\
Silver & 0.2 \\
Total Chromium & 0.62 \\
Zinc & 3.0 \\
Total Toxic Organics (TTO) & 1.0 \\
\hline
\end{tabular}




\section{Appendix C - Radiological Dose Assessment}

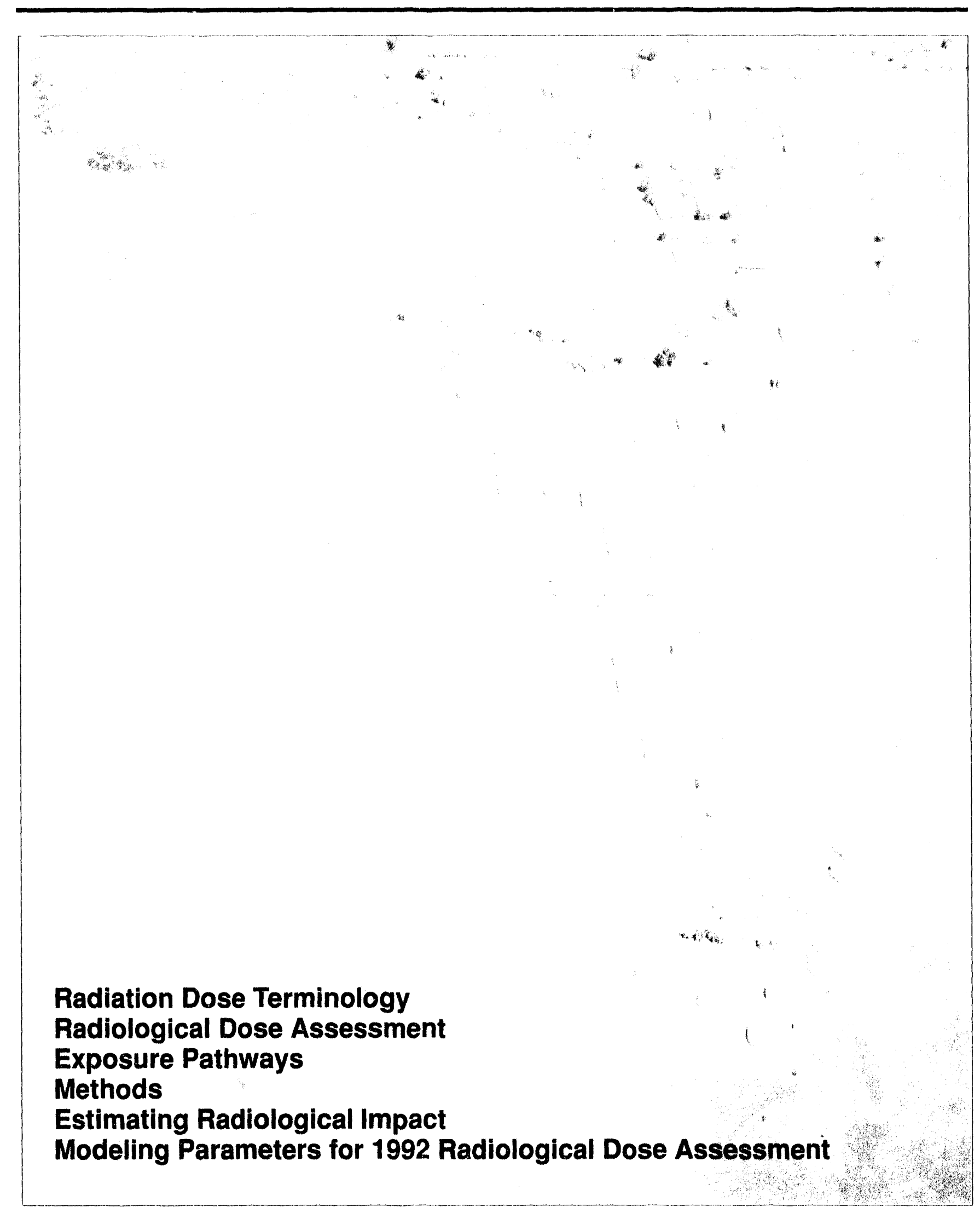




\section{Radiological Dose Assessment}

This appendix explains radiation dose terminology, describes the methods used to calculate radiation doses to the public, and provides the specific models used in the 1992 dose assessment.

\section{Radiation Dose Terminology}

\section{Internal and External Radiation Doses}

A person's radiation dose from an external (penetrating) radiation source is received only while the individual is exposed to the source. However, if radioactive material is taken into the body, the dose will continue even after the intake has ceased. The body can intake radioactive materials primarily three ways:

- ingestion of the radioactive material in food or drinking water,

- inhalation of airborne radioactive particulates or vapors, and

- absorption of the radionuclide through the skin.

Following an intake, radioactive material is distributed throughout the body according to how it is metabolized. Consequently, organs will continue to absorb energy emitted by the radionuclides remaining in the body.

The dose rate to organs will diminish over time because of radioactive decay and biological elimination. Because the body rapidly eliminates some materials, like tritium, exposure to radioactivity following intake is brief. Also, some radionuclides decay rapidly (have short half-lives), thereby minimizing exposure.

\section{Absorbed Dose and Dose Equivalent}

The absorbed radiation dose is defined as the quantity of radiation energy absorbed by an organ, divided by the organ's mass. The SI unit for absorbed dose is the gray (Gy). An organ receives an absorbed dose of $1 \mathrm{~Gy}$ when it absorbs 1 joule $(\mathrm{J})$ of radiation energy per kilogram $(\mathrm{kg})$ of its mass $(1 \mathrm{~Gy}=1 \mathrm{~J} / \mathrm{kg})$. The conventional unit of absorbed dose is the $\mathrm{rad}$ ( $100 \mathrm{rad}=1 \mathrm{~Gy}$ ).

The measure of absorbed dose is independent of the type of radiation (alpha particles, beta particles, gamma rays, or neutrons). Different types of radiation cause different levels of damage to human tissue, based on the rate of energy deposition.

The dose equivalent takes into account the type of radiation involved in the exposure. The dose equivalent is calculated by multiplying the absorbed dose by a quality factor specific to the type of radiation.

The International Commission on Radiological Protection (ICRP) has recommended specific quality factors for the radiation types most relevant to this report. DOE has adopted these quality factors, which are listed below, in DOE Order 5400.5:

- Gamma rays: 1

- Beta particles, other electrons: 1

- Alpha particles: 20

The committed dose equivalent is the predicted total dose equivalent to a tissue or organ over a 50-year period after a known intake of a radionuclide into the body. Fifty years is the approximate residual life expectancy of a young adult. 


\section{Radiological Dose Assessment}

The SI unit of dose equivalent and committed dose equivalent is the sievert (Sv). The conventional unit, used in this report, is the rem $(100 \mathrm{rem}=1 \mathrm{~Sv})$.

\section{Effective Dose Equivalent}

The effective dose equivalent (EDE) combines the dose equivalents received by all organs or tissues into a single weighted sum. The EDE is defined as the sum of all organ dose equivalents after each one has been multiplied by an appropriate weighting factor. The weighting factors were developed by the ICRP. They express the fractional risk of a stochastic health effect associated with the dose equivalent to that organ. DOE adopted the ICRP weighting factors (Wt) in DOE Order 5400.5. The EPA has accepted these factors for calculating radiation dose for determining compliance with the Clean Air Act (Title 40 CFR, Part 61, Subpart H).

The EDE combines the individual organ or tissue dose equivalents into a single riskweighted sum. EDEs can be added to determine the total risk from exposure to several radionuclides. When external radiation sources, such as an airborne plume, expose the whole body uniformly, the external EDE is added to the EDE from internal exposures.

The committed effective dose equivalent refers to the total EDE that is accumulated over a 50-year period following a single intake.

\section{Collective Effective Dose Equivalent}

Collective dose is the sum of individual doses received by all members of a population. In this report, the average individual EDE is used to calculate the collective dose for the population within a 50-mile radius. The unit of collective EDE is the personrem or person-sievert (person-Sv).

\section{Radiological Dose Assessment}

This section presents the methods, assumptions, and calculations used to assess routine radiological exposures from each significant environmental pathway. It covers routine operations involving uniform releases to the environment and is not intended for assessing consequences from accidents.

$\mathrm{SNL} /$ California annually assesses radiologic impacts of site operations on the public. This assessment is done in accordance with DOE- and EPA-approved methods. The results are published and made available to the general public each year in the SNL/California Site Environmental Report.

The radiological impacts from SNL/California operations are assessed by determining the radiologic dose to members of the public who would receive maximum credible exposures. This assessment involves the following:

- measuring radioactive emissions from SNL/California,

- identifying all relevant exposure pathways,

- evaluating environmental transport and fate of contaminants, and

- estimating human intake and resulting dose.

In most cases, the amount of radioactive material emitted by SNL/California is too small for radiologic doses to be determined from direct measurements of radionuclide 


\section{Radiological Dose Assessment}

concentrations in environmental media. That is, it is not always possible to discriminate between Sandia's contribution to radiation in the environment and natural background sources of radiation. Also, because Sandia is located adjacent to LLNL, the monitoring system cannot always differentiate the emissions from the two sites. Therefore, off-site doses are calculated based on radioactive effluent measurements at the point of discharge from the facility. Environmental transport and exposure pathway computer models are used to estimate radionuclide concentrations in various environmental media at locations accessible to the public. Dosimetric models then are applied to determine human intake and to convert intake to dose.

Radiological doses are expressed in terms of effective dose equivalent (EDE). "Dose equivalent" is a term used in radiation protection that expresses all types of radiation (alpha, beta, and so on) on a common scale for calculating the effective absorbed dose. It is the product of the absorbed dose in rads and certain modifying factors. (The unit of dose equivalent is the rem.) The "effective dose" is the hypothetical whole-body dose that would give the same risk of cancer mortality and/or serious genetic disorder as a given exposure and that may be limited to just a few organs. The EDE is equal to the sum of individual organ doses, each weighted by degree of risk that the organ dose carries. The EDE includes the committed EDE from internal deposition of radionuclides and the EDE due to penetrating radiation from sources external to the body. It is expressed in units of rem (or sievert).
The method used to calculate EDEs applies the dosimetric parameters recommended by the ICRP in Publications 26 (1977) and 30 (1980).

Doses from the air pathway also are calculated and reported to demonstrate compliance with the Federal Clean Air Act NESHAPs Rule for Radionuclides (Title 40 CFR, Part 61). These doses are calculated using the Clean Air Act Code, which contains models (AIRDOS-EPA and RADRISK) approved by the EPA for calculating atmospheric transport and exposure. Under the Clean Air Act, the EPA assumes jurisdiction over radionuclides emitted to the atmosphere, i.e., the air puthway. The air pathway dose includes radiological dose from immersion, inhalation, and ingestion, resulting from radionuclides emitted to the atmosphere. Population exposure is converted to radiation dose using dose conversion factors and weighting factors specified by the EPA.

\section{Exposure Pathways}

Figure C-1 simplistically represents the important pathways of radioactivity released to the environment. Based on the environmental pathway analysis for SNL/California and the land use characteristics on and around the site, the following doses are calculated:

- external (direct) dose at the site boundary;

- inhalation from the air pathway and submersion from plume passage; and 


\section{Radiological Dose Assessment}

Figure C-1. Major radiation exposure pathways.

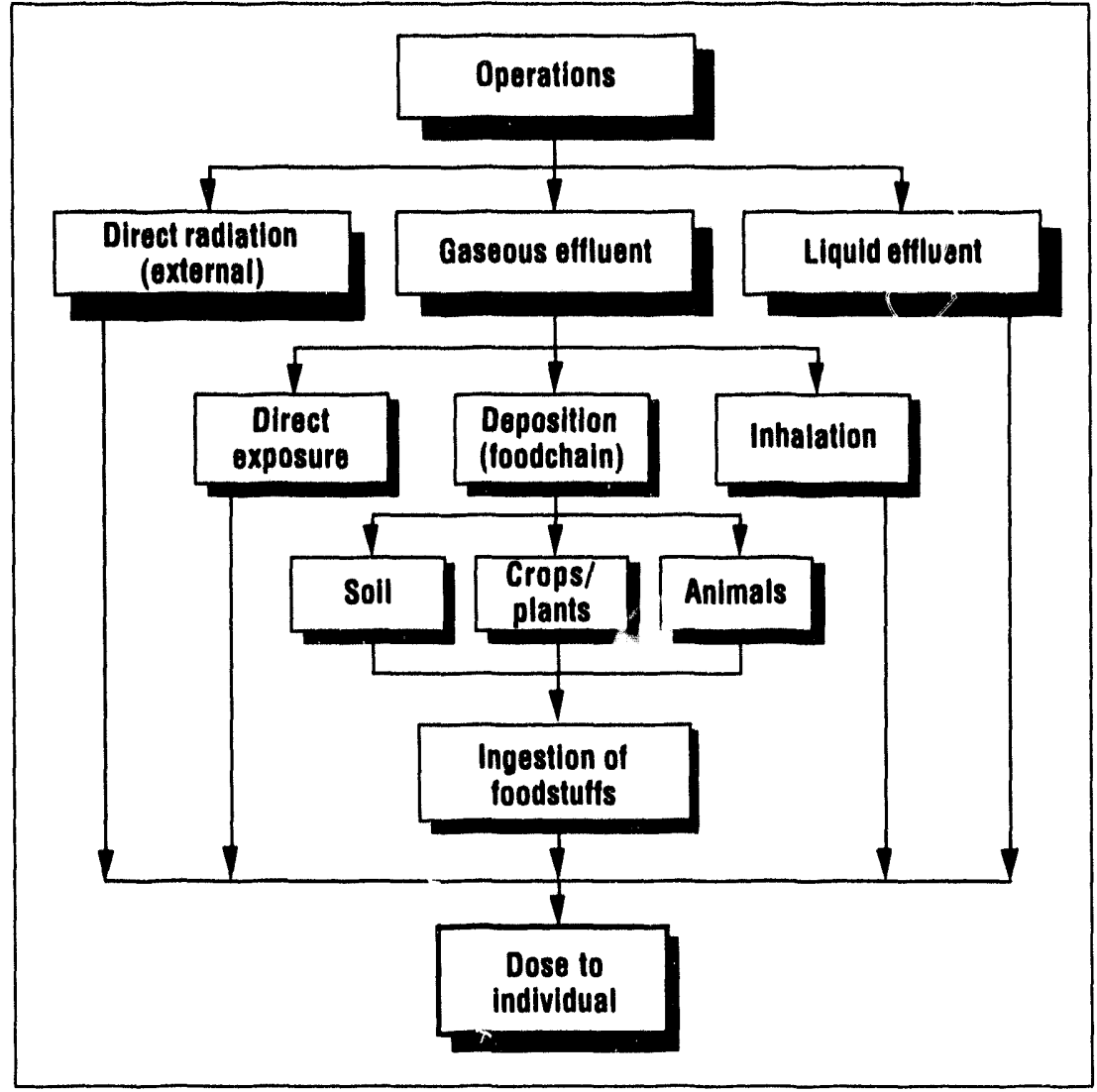

- ingestion from cosumption of locally produced foodstuffs and drinking water.

$\mathrm{SNL} /$ California has no operations that discharge liquid effluents to surface water or to the ground. These doses are determined at the point of maximum exposure in uncontrolled areas, i.e., publicly accessible locations. The doses are compared to DOE and EPA radiation protection standards. Each of the doses used to evaluate the radiological impact from $\mathrm{SNL} /$ California operations is described briefly below.

C-4 SNL/CA Site Environmental Report for 1992

\section{External "Fence-Line" Dose}

The fence-line dose rate is a measure of the maximum external radiation dose at locations of nearest uncontrolled public access.

The TLDs measure dose rates from all external radiation sources, including cosmic radiation, radioactivity that occurs naturally in the environment, fallout from nuclear weapons testing, and any contribution from SNL operations. In most cases, the dose rates are a measure of regional background, as shown by comparing the perimeter measurements to those made at off-site locations (in the Livermore Valley). Moreover, these measurements are made at points of maximum exposure and assume 


\section{Radiological Dose Assessment}

an occupancy of 24 hours a day, 365 days a year. No member of the public actually resides at these locations for extended periods of time; therefore, these estimates are conservative.

\section{Inhalation/Submersion Dose}

Air pathway doses are calculated for each airborne radioactive discharge to the atmosphere. Inhalatior. /submersion doses are calculated at the site perimeter, at the location of the nearest resident, and at the point of maximum off-site exposure. The amount of radioactivity released by $\mathrm{SNL} /$ California is usually too low for radionuclide concentrations in ambient air to be measured accurately and for dose to be determined. Therefore, environmental transport and exposure pathway models are used to calculate potential dose resulting from effluent emissions (measured at the TRL stack). The two methods used comply with both DOE standards and NESHAPs.

The atmospheric transport of radioactive materials from SNL/California is calculated based on source term and meteorological conditions. Meteorological factors (wind speed, direction, and atmospheric stability) are measured continuously at a monitoring station on the SNL/California site. Atmospheric observations are collected at two tower levels $(10 \mathrm{~m}$ and $40 \mathrm{~m})$. Because the 30-m TRL stack is being modeled, the corresponding $40-\mathrm{m}$ tower data are used.

\section{Ingestion Dose}

Potential doses from ingestion of locally produced foodstuff and surface water are based on actual measurements of radionuclide concentrations in the various media (determined by sample analysis).

Conservative exposure data and current ICRP dosimetric factors are used to estimate doses to the individual. Field measurements are used to assess tritium in water, milk, and vegetation (which includes the forage-cow-milk pathway).

\section{METHODS}

\section{External Methods}

Dose rates from external penetrating radiations (primarily gamma rays) are measured using TLDs. These dosimeters provide a direct measure of external radiation exposure rates (expressed in milliroentgens per unit time). The exposure rates are then converted to dose equivalent units (mrem) to compare to appropriate standards.

\section{Annual Inhalation and Submersion Dose Methods}

Radioactive materials released to the atmosphere are subject to complex processes, which govern their movement in the environment. Figure C-2 simplistically represents the method used to assess the inhalation/submersion pathway.

\section{Sandia Method}

The method used to calculate doses complies with the DOE primary radiation protection standards for the public. Expressed as EDEs, they also comply with the ICRP risk-based system.

Doses are calculated using a computer code based on the Gaussian plume model. This code provides ratios of concentration to release rate $(\chi / Q)$ through sixteen, $22.5^{\circ}$ compass sectors and at various distances from potential release points. The average annual $\chi / Q$ values are calculated using 


\section{Radiological Dose Assessment}

local meteorological data (obtained from sensors on the SNL/California meteorological tower from a height of $40 \mathrm{~m}$ ). Measurements of wind speed, wind direction, and atmospheric stability are tabulated at 1/4-hour intervals over the calendar year.
Variance in the horizontal wind direction is used to estimate Pasquill-Gifford stability categories, based on the method described by D. H. Slade (1968). Lateral and vertical standard deviations $\sigma_{y}$ and $\sigma_{z}$ are entered in the computer code as functions of these stability categories and the respec-

Figure C-2. Dose assessment of air pathway.

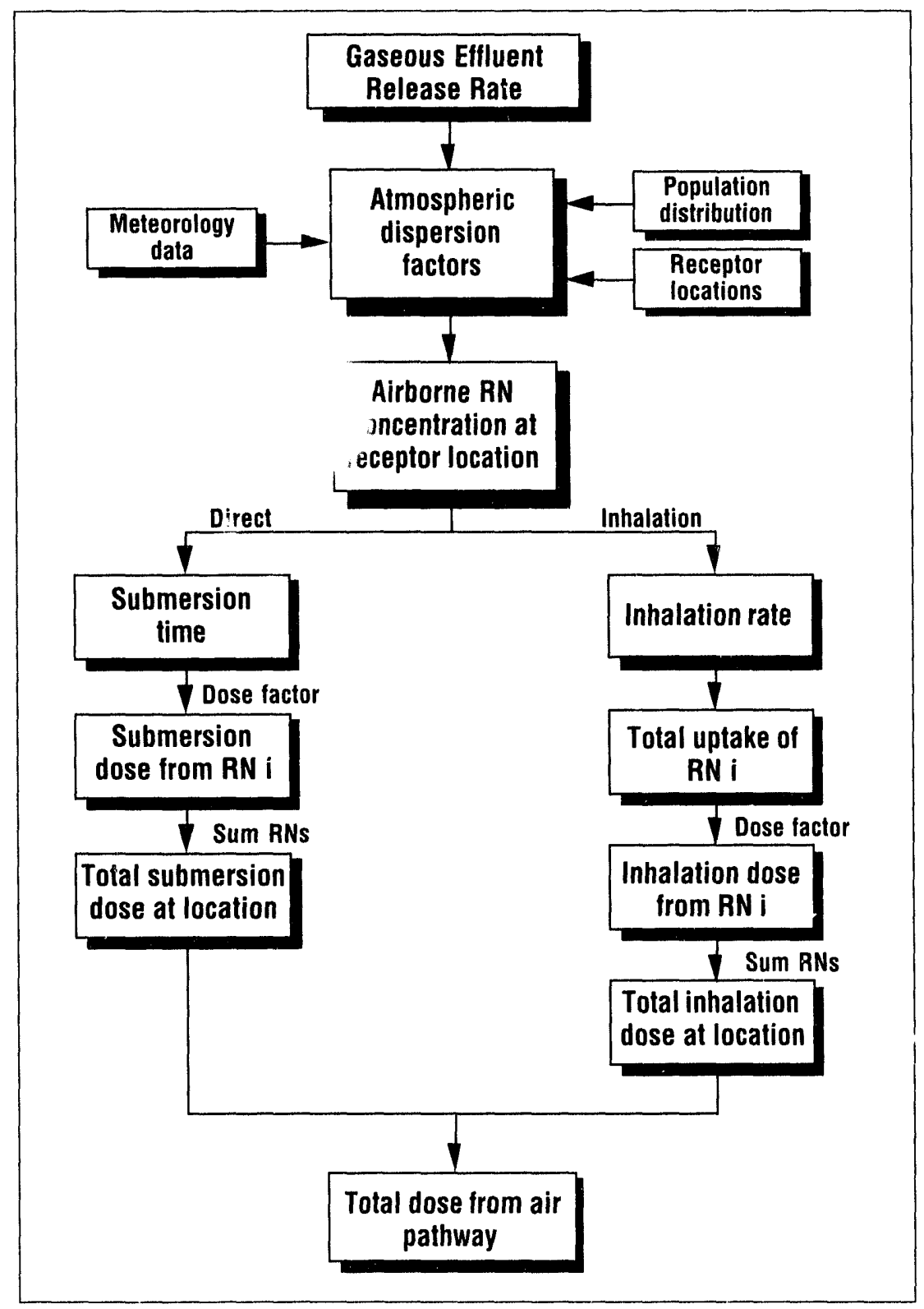




\section{Radiological Dose Assessment}

tive distances. Based on the annual effluent data and the appropriate $\chi / Q$ values, the radionuclide concentrations at the site perimeter and at the location of the nearest resident are calculated.

The atmospheric dispersion parameter $(\chi / Q)$ is calculated based on the distance from the facility to the receptor location (i.e., site perimeter, nearest resident, and point of maximum ground-level concentration). This process is repeated for each facility that discharges radioactive matter to the atmosphere. Once the code has calculated the dispersion parameter, it multiplies the parameter by the release rate and the standard human inhalation rate, to obtain intake. Dose conversion factors provided by DOE are used to relate the intake of radioactive material to dose commitment. These dose factors provide estimates of 50year doses from a chronic one-year intake of radioactivity.

Following are the calculations of air pathway dose at the perimeter, the location of the nearest resident, and the point of maximum exposure.

Inhalation and Submersion Dose (D) Calculations $\left({ }^{3} \mathrm{H}\right)$ :

$$
\mathrm{D}_{\max }=\mathrm{C} \times \mathrm{U} \times \mathrm{D},
$$

where

$$
\begin{aligned}
& \mathrm{C}=\text { radionuclide concentration at the } \\
& \text { receptor, } \\
& U=\text { intake rate (the inhalation rate for } \\
& \mathrm{D}=\text { tritium dose conversion factor } \\
& \left(9.45 \times 10^{-8} \mathrm{mrem} / \mathrm{pCi}\right) \text {. }
\end{aligned}
$$

(The tritium dose conversion factor was obtained by multiplying the inhalation dose factor, $6.3 \times 10^{-8} \mathrm{mrem} / \mathrm{pCi}$, by 1.5 , to include absorption through the skin).

The radionuclide concentration at the receptor, $\mathrm{C}$, is calculated as follows:

$$
\mathrm{C}=3.17 \times 10^{4} \mathrm{Ci} / \mathrm{m}^{3}(\chi / \mathrm{Q})(\mathrm{Q}) \text { ， }
$$

where

$$
\begin{aligned}
& \chi / \mathrm{Q}=\text { diffusion parameter }\left(\mathrm{s} / \mathrm{m}^{3}\right), \\
& \mathrm{Q}=\text { release rate, } \mathrm{Ci} / \mathrm{yr}, \\
& 3.17 \times 10^{4}=\frac{1 \times 10^{12} \mathrm{pCi} / \mathrm{Ci}}{3.15 \times 10^{7} \mathrm{~s} / \mathrm{yr}}
\end{aligned}
$$

Assessment Assumptions:

Tritium emissions account for all the off-site dose from SNL/California operations. Tritium exits the site in two major forms: tritium oxide or vapor $\left(\mathrm{HTO}\right.$ or $\left.\mathrm{T}_{2} \mathrm{O}\right)$ and elemental tritium ( $\mathrm{HT}$ or $\mathrm{T}_{2}$ ). Any $\mathrm{HTO}$ that enters the body is distributed throughout and is eliminated at the same rate as body water. Only a small fraction of HT is retained. The EDE from exposure to elemental tritium in air is 25,000 times lower than an equal exposure to tritium oxide. For this reason, elemental tritium is excluded from the dose calculations.

\section{Clean Air Act NESHAPs Method}

SNL/California is required to calculate and report radiological doses pursuant to NESHAPs (Title 40 CFR, Part 61, subpart $\mathrm{H})$. The EPA dose limits apply only to exposure to members of the public from airborne emissions of radionuclides. This assessment includes exposures from inhalation, air submersion, ingestion, and ground 


\section{Radiological Dose Assessment}

surface irradiation resulting from airborne emissions.

The EPA regulations require that the dose assessment be done using an approved version of the Clean Air Act Code (CAAC), such as CAP88.

SNL/California uses a personal computer version of CAP88, called CAP88-PC, to demonstrate compliance with the NESHAPs Rule for Radionuclides. Human intake is converted to dose using dose conversion and weighting factors specified by the EPA. For this method, the models and parameters used to predict the transport of radionuclides in the environment and to estimate dose meet EPA requirements.

The assessment methodology was developed for the U.S. EPA Office of Radiation Programs by Oak Ridge National Laboratory. Human exposure data are derived from the atmospheric and environmental transport code (Moore, 1979). The dosimetric and health effects database used was developed by the RADRISK computer code (Dunning, 1980). The DARTAB computer code (Begouich, 1981) is used to predict dose (and radiation-induced health effects, if desired) from the human exposure and health effects data.

The CAP88 computer model is used to estimate radiological doses associated with routine emission of radionuclides. This computer model estimates: radionuclide concentrations in air; deposition rates on ground surfaces; ground surface concentrations; intake rates via inhalation of air and ingestion of meat, milk, and fresh vegetables; and radiation doses to humans from airborne releases of radionuclides. An internal library of dose conversion factors com- bines radionuclide environmental exposure data with dosimetric and health effects data to generate tabulations of the predicted impact (in terms of EDE) of radioactive airborne effluents.

The CAP88-PC model calculates atmospheric dispersion for radionuclides released from stacks or area sources. Radionuclide concentrations in meat, milk, and fresh produce are estimated by coupling the deposition rate output of the atmospheric dispersion models with the NRC Regulatory Guide 1.109 terrestrial food chain models. Radionuclide concentrations for specified distances and directions are calculated for the following exposure pathways:

- immersion in air containing radionuclides;

- exposure to ground surfaces contaminated by deposited radionuclides;

- inhalation of radionuclides in air; and

- ingestion of food in the area.

CAP88-PC uses a modified Gaussian plume dispersion model to calculate annual average radionuclide concentrations for each grid sector. Building wake effects and downwash are not included in the model. The same type of plume rise calculation (buoyant, momentum, or fixed) is used for all sources.

Input into CAP88-PC includes a source term that describes facility-specific parameters and options that control the dispersion model and exposure calculations.

Meteorological data are also required as input. The source term includes annual radionuclide release rates and stack height, 
diameter, heat release rate, and stack gas exit velocity.

Input values for the food chain model are found in Radionuclides Background Information Document for Final Rules. All agriculture production parameters are assigned default values.

\section{Environmental Measurements Method}

The amount of radioactivity released from SNL/California is very small-often too small to discriminate between it and background radiation sources. Inhalation doses can be calculated based on field measurements of airborne tritium. The EDE for tritium is calculated using the following equation:

$$
\mathrm{D}\left({ }^{3} \mathrm{H}\right)=\mathrm{C} \times \mathrm{U} \times \mathrm{DF},
$$

where

$$
\begin{aligned}
& \mathrm{D}\left({ }^{3} \mathrm{H}\right)=\quad \begin{array}{l}
\text { effective dose equivalent } \\
\text { from inhalation of }{ }^{3} \mathrm{H}, \\
\text { mrem } / \mathrm{yr}
\end{array} \\
& \mathrm{C}=\quad \begin{array}{l}
3 \mathrm{H} \text { concentration in air at } \\
\text { receptor location, } \mathrm{pCi} / \mathrm{m}^{3}
\end{array} \\
& \mathrm{U}=\quad \begin{array}{l}
\text { intake rate (inhalation rate } \\
\text { of standard man), } 8400
\end{array} \\
& \mathrm{~m}^{3} / \mathrm{yr} \text {, and } \\
& \mathrm{DF}=\quad \begin{array}{l}
\text { dose conversion factor for } \\
3 \mathrm{H}, 9.45 \times 10^{-8} \mathrm{mrem} / \mathrm{pCi} .
\end{array}
\end{aligned}
$$

By multiplying $U$ and DF, the final, simplified equation becomes:
$\mathrm{D}\left({ }^{3} \mathrm{H}\right)=$
$\mathrm{C} \times 7.94 \times 10^{-4}$

\section{Ingestion Dose Methods}

Potential dose from ingestion of locally produced foodstuff and surface water are estimated by environmental sampling and computer modeling techniques. The dose assessment influences each of the significant agricultural products of the Livermore Valley. These include general vegetation and milk. Figure C-3 illustrates the terrestrial food chain pathway analysis. Doses are also calculated for drinking water at each of the eight Livermore Valley water sampling locations. None of these locations are primary sources of drinking water. However, to provide an upper-bound estimate of dose at each location, a hypothetical person is assumed to obtain all his/her drinking water (2 L/day) from that source.

\section{CAP88-PC Computer Method}

The CAP88-PC code is used to calculate ingestion doses based on airborne emission data. The doses are calculated from deposition of radionuclides on crop land and pasture. CAP88-PC uses the models from the NRC Regulatory Guide 1.109 to estimate annual doses to man from vegetables, meat, and milk consumption. Dose conversion factors are specified by the EPA.

\section{Environmental Measurements Method}

Data from the sampling and analysis of water and foodstuffs are also used to estimate dose.

\section{Annual Dose from Potable Water}

Assuming that all water sampled is available as drinking water, the annual wholebody dose for tritium is calculated using the following equation: 


\section{Radiological Dose Assessment}

Figure C-3. Dose assessment of terrestrial food chain pathway.

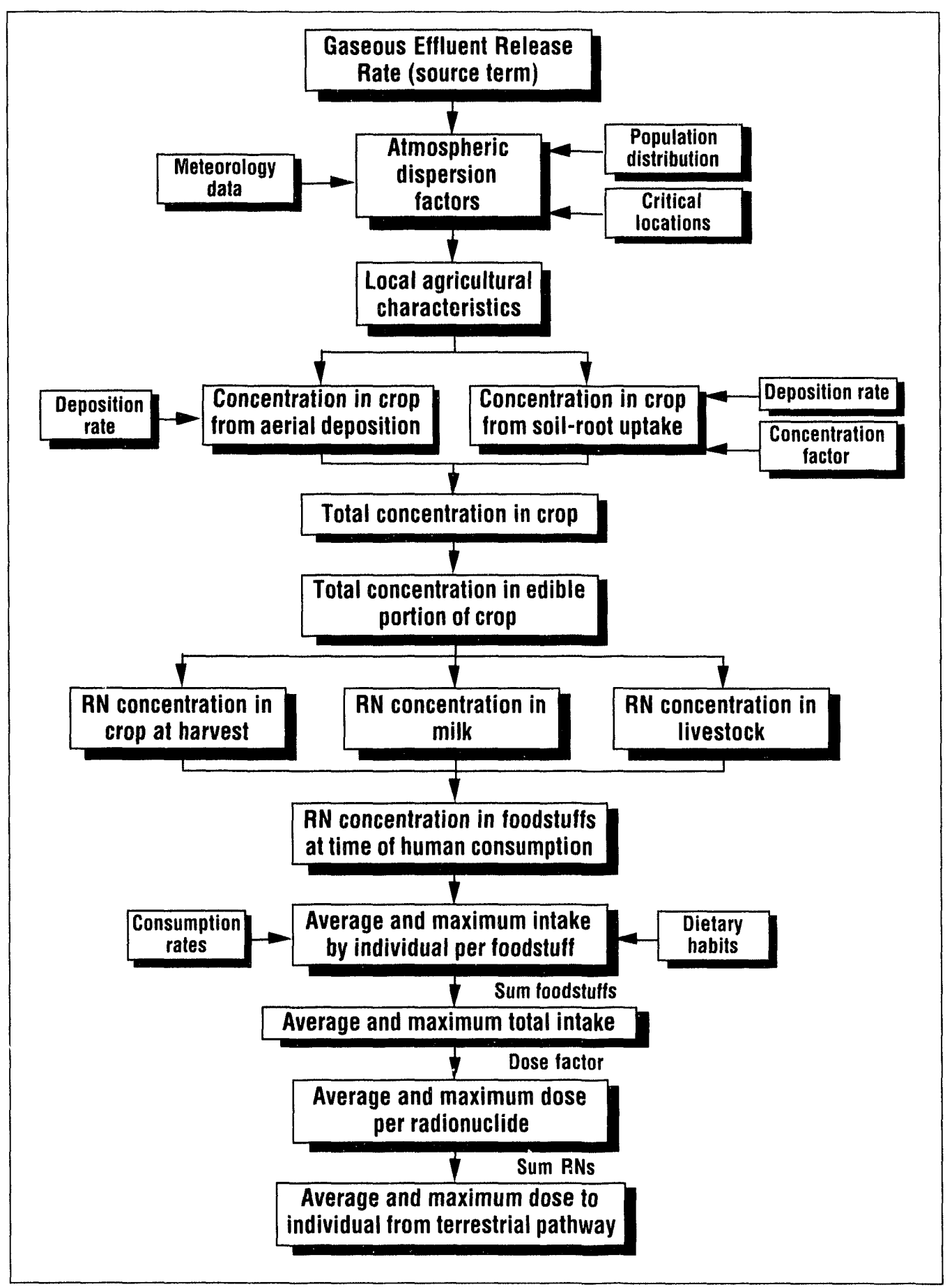




\section{Radiological Dose Assessment}

$$
\mathrm{R}_{\text {whole body }}=\mathrm{C}_{\mathrm{w}} \mathrm{U}_{\mathrm{w}} \mathrm{D}_{\mathrm{w}}
$$

where

$$
\begin{aligned}
\mathrm{C}_{\mathrm{w}}= & \text { concentration }(\mathrm{pCi} / \mathrm{L}), \\
\mathrm{U}_{\mathrm{w}}= & \begin{array}{l}
\text { intake rate }(\mathrm{L} / \mathrm{yr})=730 \mathrm{~L} / \mathrm{yr} \\
\text { for maximum exposed indi- } \\
\text { vidual, and }
\end{array} \\
\mathrm{D}_{\mathrm{w}}= & \begin{array}{l}
\text { dose factor }(\mathrm{mrem} / \mathrm{pCi})= \\
6.3 \times 10^{-8} \mathrm{mrem} / \mathrm{pCi} \text { for the } \\
\text { whole-body ingestion path- } \\
\text { way for an adult. }
\end{array}
\end{aligned}
$$

$R_{\text {whole body }}$ is the EDE in mrem from ingestion of $730 \mathrm{~L}$ of potable water with concentration $\mathrm{C}_{\mathrm{w}}$.

\section{Annual Dose from Forage-Cow Milk Pathway for Tritium in Vegetation}

Assuming that all feed for the cattle was pasture grass, the effective dose equivalent per $\mathrm{mCi} / \mathrm{mL}$ of $\mathrm{HTO}$ for the maximum exposed individual has been calculated using the following equation:

$D_{\text {whole body }}=D_{\text {veg }}+D_{\text {meat }}+D_{\text {milk }}$

Broken down, each of these elements can be expressed as follows.

$$
\mathrm{D}_{\text {veg* }}=\mathrm{U}_{\mathrm{veg}} \times \mathrm{C}_{\mathrm{veg}} \times \mathrm{D}_{\mathrm{HTO}} ，
$$

*leafy vegetables

where

$$
\begin{aligned}
& \mathrm{U}_{\mathrm{veg}}= \begin{array}{l}
\text { intake rate }(\mathrm{kg} / \mathrm{yr})=64 \mathrm{~kg} / \mathrm{yr} \\
\text { for maximally exposed } \\
\text { individual, }
\end{array} \\
& \mathrm{C}_{\mathrm{veg}}= \text { concentration }(\mathrm{pCi} / \mathrm{kg}) \\
&= 10^{9} \frac{\mathrm{pCi} / \mathrm{kg}}{\mu \mathrm{Ci} / \mathrm{mL}} \times \mathrm{C}_{\mathrm{veg}} \mu \mathrm{Ci} / \mathrm{mL} \\
& \text { (measured), }
\end{aligned}
$$

$$
\begin{aligned}
\mathrm{D}_{\mathrm{HTO}}= & \text { dose factor }(\mathrm{mrem} / \mathrm{pCi}) \\
= & \begin{array}{l}
6.3 \times 10^{-8} \mathrm{mrem} / \mathrm{pCi} \text { for }{ }^{3} \mathrm{H} \text { for } \\
\text { the adult whole-body ingestion } \\
\text { pathway. }
\end{array}
\end{aligned}
$$

Thus,

$$
\begin{aligned}
& \mathrm{D}_{\text {veg }}= \\
& (\mathrm{mrem} / \mathrm{yr})
\end{aligned}
$$

$$
\mathrm{D}_{\text {meat }}=\mathrm{U}_{\text {meat }} \times \mathrm{D}_{\text {HTO }} \times \mathrm{C}_{\text {meat }},
$$

whe: $\mathrm{e}$

$$
\begin{aligned}
& \mathrm{U}_{\text {meat }}=110 \mathrm{~kg} / \mathrm{yr}, \\
& \mathrm{D}_{\mathrm{HTO}}=6.3 \times 10^{-8} \mathrm{mrem} / \mathrm{pCi}, \text { and } \\
& \mathrm{C}_{\text {meat }}=\left(\mathrm{F}_{f}\right)\left(\mathrm{Q}_{f}\right)\left(\mathrm{C}_{\mathrm{veg}}\right) \exp \left(-\gamma_{\mathrm{i}} \tau_{\mathrm{s}}\right),
\end{aligned}
$$

where

$$
\begin{aligned}
& \mathrm{F}_{f}=\quad \begin{array}{l}
\text { fraction of daily intake of } \\
\text { nuclide per } \mathrm{kg} \text { of animal } / \text { fish } \\
(\mathrm{pCi} / \mathrm{kg} \text { in meat per } \mathrm{pCi} / \text { day }
\end{array} \\
& \begin{array}{l}
\text { ingested by the animal), } \\
\text { days } / \mathrm{kg},
\end{array} \\
& \mathrm{Q}_{f}=\begin{array}{l}
\text { amount of feed consumed } \\
(\mathrm{kg} / \text { day), }
\end{array} \\
& \mathrm{C}_{\mathrm{veg}}=\begin{array}{l}
\text { concentration }(\mathrm{pCi} / \mathrm{kg}), \\
\gamma_{\mathrm{i}}= \\
\text { radiological decay constant, } \\
\text { day-1, and }
\end{array} \\
& \tau_{\mathrm{s}}=\begin{array}{l}
\text { time between slaughter to con- } \\
\text { sumption (days) }
\end{array}
\end{aligned}
$$

Simplified,

$$
\begin{aligned}
\mathrm{C}_{\text {meat }}= & \left(1.2 \times 10^{-2} \mathrm{day} / \mathrm{kg}\right)(50 \mathrm{~kg} / \text { day }) \\
& \left(\mathrm{C}_{\text {veg }} \mu \mathrm{Ci} / \mathrm{ml}\right)\left(10^{9} \frac{\mathrm{pCi} / \mathrm{kg}}{\mu \mathrm{Ci} / \mathrm{mL}}\right) \\
& \times \exp \left[-1.5 \times 10^{-4}(20)\right]
\end{aligned}
$$




\section{Radiological Dose Assessment}

$$
\begin{aligned}
& =0.6 \times 10^{9} \frac{\mathrm{pCi} / \mathrm{kg}}{\mu \mathrm{Ci} / \mathrm{mL}} \times \mathrm{C}_{\text {veg }} \mu \mathrm{Ci} / \mathrm{mL} \quad=\quad 0.5 \times 10^{9} \frac{\mathrm{pCi} / \mathrm{kg}}{\mu \mathrm{Ci} / \mathrm{mL}} \times \mathrm{C}_{\mathrm{veg}} \mu \mathrm{Ci} / \mathrm{mL} \\
& \text { (measured). }
\end{aligned}
$$

Thus,

$D_{\text {meat }}=0.41 \times 10^{4} \mathrm{C}_{\text {veg }} \mu \mathrm{Ci} / \mathrm{mL}$ (measured). (mrem/yr)

(3)

$$
D_{\text {milk }}=U_{\text {milk }} \times D_{\text {HTO }} \times C_{\text {milk }},
$$

where

$$
\begin{aligned}
& \mathrm{U}_{\text {milk }}=310 \mathrm{~L} / \mathrm{yr}, \\
& \mathrm{D}_{\text {HTO }}=6.3 \times 10^{-8} \mathrm{mrem} / \mathrm{pCi}, \text { and } \\
& \mathrm{C}_{\text {milk }}=\mathrm{F}_{\mathrm{m}} \mathrm{Q}_{\mathrm{f}} \mathrm{C}_{\mathrm{veg}} \exp \left(-\gamma_{\mathrm{i}} \tau_{\mathrm{f}}\right),
\end{aligned}
$$

Thus,

$$
\begin{aligned}
& \mathrm{D}_{\text {milk }}= \\
& \text { (mrem/yr) }
\end{aligned}
$$

Combining all three elements, the final equation becomes:

$$
\begin{aligned}
\begin{array}{c}
\mathrm{D}_{\text {whole body }}= \\
\text { (mrem/yr) }
\end{array} & 0.40 \times 10^{4} \mathrm{C}_{\text {veg }} \mu \mathrm{Ci} / \mathrm{mL} \text { (measured) } \\
& +0.41 \times 10^{4} \mathrm{C}_{\text {veg }} \mu \mathrm{Ci} / \mathrm{mL} \text { (measured) } \\
& +0.97 \times 10^{4} \mathrm{C}_{\text {veg }} \mu \mathrm{Ci} / \mathrm{mL} \text { (measured) } \\
= & 1.78 \times 10^{4} \mathrm{C}_{\text {veg }} \mu \mathrm{Ci} / \mathrm{mL} \text { (measured) }
\end{aligned}
$$

where

$$
\begin{aligned}
& \mathrm{F}_{\mathrm{m}}=\text { fraction of daily intake of } \\
& \mathrm{C}_{\mathrm{veg}}=\text { concentration }(\mathrm{pCi} / \mathrm{kg}) \text {, } \\
& \gamma_{\mathrm{i}}=\text { radiological decay constant, } \\
& \text { day }^{-1} \text {, } \\
& \tau_{\mathrm{f}}=\text { transport time from the feed to } \\
& \text { milk receptor. }
\end{aligned}
$$

Simplified,

$$
\begin{aligned}
\mathrm{C}_{\text {milk }}= & \left(1.2 \times 10^{-2} \mathrm{~L} / \text { day }\right)(50 \mathrm{~kg} / \text { day }) \\
& \left(\mathrm{C}_{\mathrm{veg}} \mu \mathrm{Ci} / \mathrm{mL}\right) 10^{9} \frac{\mathrm{pCi} / \mathrm{kg}}{\mu \mathrm{Ci} / \mathrm{mL}} \\
& \times \exp \left[1.5 \times 10^{-4}(2)\right]
\end{aligned}
$$

\section{Annual Dose from Milk}

The radiation dose (mrem) from tritium in milk is calculated using the annual average HTO concentration in Livermore Valley milk samples collected during the year. The following equation is used:

$$
\mathrm{D}_{\text {milk }}=\mathrm{U}_{\text {milk }} \times \mathrm{D}_{\mathrm{HTO}} \times \mathrm{C}_{\text {milk }} \text {, }
$$

where

$$
\begin{aligned}
U_{\text {milk }}= & 310 \mathrm{~L} / \mathrm{yr}, \\
\mathrm{D}_{\text {HTO }}= & 6.3 \times 10^{-8} \mathrm{mrem} / \mathrm{pCi}, \text { and } \\
\mathrm{C}_{\text {milk }}= & \begin{array}{l}
\text { annual average } \mathrm{HTO} \text { con- } \\
\text { centration in milk, in } \\
\mathrm{pCi} / \mathrm{L} .
\end{array}
\end{aligned}
$$

By multiplying $U$ and $D$, this equation simplifies to:

$$
D_{\text {milk }}=C_{\text {milk }} \times 2 \times 10^{-5}
$$

\section{Estimating Radiological Impact Maximally Exposed Individual Dose} The maximally exposed individual dose represents the maximum credible dose to a 
hypothetical member of the general public. It includes contributions from all potential exposure pathways and is derived using conservative but realistic exposure data and assumptions. The hypothetical person is assumed to reside at the point of highest ground-level, radionuclide air concentration continuously for 24 hours a day, 365 days a year. During this occupancy period, a portion of the person's diet consists of locally produced foodstuffs and drinking water containing the highest measured radionuclide concentration. Rainwater is specifically excluded as a source of drinking water in these calculations. Thus, this dose is not actually received by any individual-it is a conservative estimate (i.e., over-estimate) of the highest possible dose that could be received by a member of the public.

The maximum dose is calculated by summing the doses from all credible exposure pathways. This can be expressed as:

$$
D_{\max }=D_{\text {external }}+D_{\text {inhalation }}+D_{\text {ingestion }} \text {. }
$$

\section{Collective Population Dose}

The collective population dose is the dose for all people living within a 50-mile $(80-\mathrm{km})$ radius of the site. There are no regulatory limits for population doses. However, DOE Order 5400.5 requires an evaluation of the collective population dose. The population dose is calculated by summing the product of the individual dose and the number of people residing in each sector, for all potential exposure pathways. The collective population dose is referred to as the "collective effective dose equivalent." It is expressed in terms of person-rem (person-Sv).

The EDEs in this report have been calculated according to models and methods consistent with the NRC Regulatory Guide 1.109, Calculation of Annual Doses to Man from Routine Releases of Reactor Effluent. The dose and dose-rate conversion factor used in these calculations were obtained from the committed dose equivalent tables for DOE dose calculations. These dose conversion factors are consistent with those specified in ICRP 30.

For population dose, the diffusion parameters and population figures for a sector, $i$, within $80 \mathrm{~km}$ of SNL/California are summed over all directions, $n$.

$$
\begin{aligned}
& \mathrm{D}=32.17 \times 10^{4}\left[\sum_{i}^{\mathrm{n}}(\chi / \mathrm{Q})_{i} \mathrm{P}_{i}\right] \mathrm{QUD}, \\
& \text { (person-mrem) } \\
& \text { where } \\
& {\left[\sum_{i}^{\mathrm{n}}(\chi / \mathrm{Q})_{i} \mathrm{P}_{i}\right]=\begin{array}{l}
\text { Sum of the }(\chi / \mathrm{Q}) \text { for sector, } i, \\
\text { times the population in sector, }
\end{array}} \\
& i \text {, for all regions, } \mathrm{n} \text {, persons- } \\
& \mathrm{s} / \mathrm{m}^{3} \text {. } \\
& \mathrm{Q}=\text { release rate, in } \mathrm{Ci} / \mathrm{yr} \text {, } \\
& \mathrm{U}=\text { inhalation rate, average } \\
& \text { individual (adult), } \\
& \mathrm{D}=\text { dose factor, in } \mathrm{mrem} / \mathrm{pCi} \text {, } \\
& \mathrm{P}_{i}=\text { the population of the } i \text { th }
\end{aligned}
$$

\section{Modeling Parameters for 1992 Radiological Dose Assessment}

Tables C-1-C-7 present the specific modeling input and parameters used in the 1992 dose assessment. 


\section{Radiological Dose Assessment}

\section{Table C-1. General Description of Radiological Dose Assessment Modeling Parameters.}

\begin{tabular}{ll}
\hline \multicolumn{1}{c}{ Parameter } & \multicolumn{1}{c}{ Description } \\
\hline Site & Sandia National Laboratories, Livermore, CA \\
Facility & Tritium Research Laboratory (TRL) \\
Assessment Period & Calendar Year 1992 \\
Model & Clean Air Act Compliance Package-1988 (CAP88-PC) \\
\hline
\end{tabular}

Table C-2. Source Characteristics.

\begin{tabular}{lc}
\hline \multicolumn{1}{c}{ Parameter (TRL) } & Description \\
\hline Stack Height & $30 \mathrm{~m}$ \\
Stack Diameter & $1.4 \mathrm{~m}$ \\
Exit Gas Temperature & Ambient \\
$\begin{array}{l}\text { Exit Gas Velocity (momentum } \\
\text { plume rise) }\end{array}$ & $1.5 \mathrm{~m} / \mathrm{s}$ \\
\hline
\end{tabular}

\section{Table C-3. Radionuclide Characteristics.}

\begin{tabular}{lc}
\hline \multicolumn{1}{c}{ Parameter (TRL) } & Description \\
\hline Radionuclide & Tritium \\
Total Quantity Discharged (1992) & $264 \mathrm{Ci}^{\star}$ \\
Half-life & 12.3 years \\
\hline
\end{tabular}

*The source term consisted of $134 \mathrm{Ci} \mathrm{HTO}$ and $130 \mathrm{Ci} \mathrm{HT}$. For modeling purposes, all tritium was assumed to be in the oxide form (HTO).

Table C-4. Site Information.

\begin{tabular}{lc}
\hline \multicolumn{1}{c}{ Parameter } & Description \\
\hline Average Temperature & $15^{\circ} \mathrm{C}$ \\
Annual Precipitation & $31 \mathrm{~cm}$ \\
Mixing Height & $700 \mathrm{~m}$ \\
Average Wind Speed & $2.1 \mathrm{~m} / \mathrm{s}$ \\
\hline
\end{tabular}




\section{Radiological Dose Assessment}

\section{Table C-5. Modeling Parameters.}

\begin{tabular}{|c|c|}
\hline Description & Value \\
\hline Human Inhalation Rate $\left(\mathrm{cm}^{3} / \mathrm{hr}\right.$.) & $9.17 \times 10^{5}$ \\
\hline $\begin{array}{l}\text { Soil Parameters [effective surface density }\left(\mathrm{kg} / \mathrm{m}^{2} \text {, dry weight, }\right. \\
\text { assumes } 15 \mathrm{~cm} \text { plow layer)] }\end{array}$ & $2.15 \times 10^{2}$ \\
\hline $\begin{array}{l}\text { Buildup Times (year) } \\
\quad \text { For activity in soil } \\
\text { For radionuclides deposited on ground or water }\end{array}$ & $\begin{array}{l}100 \\
100\end{array}$ \\
\hline $\begin{array}{l}\text { Delay Times (day) } \\
\text { Ingestion of pasture grass by animals } \\
\text { Ingestion of stored feed by animals } \\
\text { Ingestion of leafy vegetables by man } \\
\text { Ingestion of produce by man } \\
\text { Transport time from aninal feed-milk-man } \\
\text { Time from slaughter to consumption }\end{array}$ & $\begin{array}{r}0 \\
90 \\
14 \\
14 \\
2 \\
20\end{array}$ \\
\hline $\begin{array}{l}\text { Weathering (hour) } \\
\text { Removal rate constant for physical loss }\end{array}$ & .0029 \\
\hline $\begin{array}{l}\text { Crop Exposure Duration (day) } \\
\text { Pasture grass } \\
\text { Crops/leafy vegetables }\end{array}$ & $\begin{array}{l}30 \\
60\end{array}$ \\
\hline $\begin{array}{l}\text { Agricultural Productivity }\left(\mathbf{k g} / \mathbf{m}^{2}\right) \\
\text { Grass-cow-milk-man pathway } \\
\text { Produce or leafy vegetables for human consumption }\end{array}$ & $\begin{array}{l}0.28 \\
0.716\end{array}$ \\
\hline $\begin{array}{l}\text { Fallout Interception Fractions } \\
\text { Vegetables } \\
\text { Pasture }\end{array}$ & $\begin{array}{l}0.20 \\
0.57\end{array}$ \\
\hline $\begin{array}{l}\text { Grazing Parameters } \\
\text { Fraction of year animals graze on pasture } \\
\text { Fraction of daily feed that is pasture grass when animal grazes on } \\
\text { pasture }\end{array}$ & $\begin{array}{l}0.40 \\
0.43\end{array}$ \\
\hline
\end{tabular}




\section{Radiological Dose Assessment}

\section{Table C-6. Values For Radionuclide-Independent Parameters.}

\begin{tabular}{|c|c|}
\hline Description & Value \\
\hline $\begin{array}{l}\text { Animal Feed Consumption Factors (kg/day, dry weight) } \\
\text { Contaminated feed/forage }\end{array}$ & 15.6 \\
\hline $\begin{array}{l}\text { Daily Productivity (L/day) } \\
\text { Milk production of cow }\end{array}$ & 11.0 \\
\hline $\begin{array}{l}\text { Meat Animal Slaughter Parameters } \\
\text { Muscle mass of animal at slaughter (kg) } \\
\text { Fraction of herd slaughtered (day) }\end{array}$ & $\begin{array}{r}200 \\
.00381\end{array}$ \\
\hline $\begin{array}{l}\text { Decontamination } \\
\text { Fraction of radioactivity retained after washing leafy vegetables } \\
\text { and produce }\end{array}$ & .50 \\
\hline $\begin{array}{l}\text { Fractions Grown in Garden of Interisst } \\
\text { Produce ingested } \\
\text { Leafy vegetables ingested }\end{array}$ & $\begin{array}{l}1.0 \\
1.0\end{array}$ \\
\hline $\begin{array}{l}\text { Ingestion Ratios } \\
\text { Total within immediate surrounding area- } \\
\text { Vegetables } \\
\text { Meat } \\
\text { Milk }\end{array}$ & $\begin{array}{l}0 \\
0 \\
0\end{array}$ \\
\hline $\begin{array}{l}\text { Minimum ingestion fractions (minimum fractions of food types } \mathrm{fr} \\
\text { outside area are actual fixed values)- } \\
\text { Vegetables } \\
\text { Meat } \\
\text { Milk }\end{array}$ & $\begin{array}{l}1.0 \\
1.0 \\
1.0\end{array}$ \\
\hline $\begin{array}{l}\text { Human Food Use Factors } \\
\text { Produce ingestion }\left(\mathrm{kg} / \mathrm{y}^{\prime \prime \prime}\right) \\
\text { Milk ingestion }(\mathrm{L} / \mathrm{yr}) \\
\text { Meat ingestion }(\mathrm{kg} / \mathrm{yr}) \\
\text { Leafy vegetable ingestion }(\mathrm{kg} / \mathrm{yr})\end{array}$ & $\begin{array}{r}176 \\
112 \\
85 \\
18\end{array}$ \\
\hline
\end{tabular}


Radiological Dose Assessment

Table C-7A. Harmonic Average Wind Speeds (Wind Towards).

\begin{tabular}{lccccccccc}
\hline & \multicolumn{7}{c}{ Pasquill Stability Class } & W \\
\cline { 2 - 7 } Direction & A & B & C & D & E & F & G & $\begin{array}{c}\text { Wind } \\
\text { Frequency }\end{array}$ \\
\hline N & 0.840 & 1.087 & 1.824 & 2.104 & 1.455 & 0.811 & 0.000 & 0.041 \\
NNW & 0.726 & 2.252 & 2.956 & 2.095 & 1.247 & 0.831 & 0.000 & 0.039 \\
NW & 0.843 & 2.166 & 1.398 & 1.461 & 1.335 & 0.889 & 0.000 & 0.064 \\
WNW & 0.822 & 1.086 & 2.427 & 1.174 & 1.261 & 0.917 & 0.000 & 0.075 \\
W & 0.826 & 1.018 & 1.167 & 1.104 & 1.031 & 0.890 & 0.000 & 0.049 \\
WSW & 1.277 & 1.426 & 1.549 & 1.423 & 1.004 & 0.738 & 0.000 & 0.034 \\
SW & 1.004 & 1.663 & 2.948 & 2.564 & 1.284 & 0.787 & 0.000 & 0.054 \\
SSW & 1.431 & 2.195 & 3.022 & 3.550 & 1.015 & 0.787 & 0.000 & 0.034 \\
S & 1.183 & 1.524 & 2.417 & 4.393 & 0.825 & 0.746 & 0.000 & 0.029 \\
SSE & 1.032 & 1.521 & 2.114 & 2.365 & 0.889 & 0.766 & 0.000 & 0.018 \\
SE & 1.114 & 1.372 & 1.286 & 1.882 & 0.790 & 0.672 & 0.000 & 0.016 \\
ESE & 1.414 & 1.768 & 2.477 & 2.905 & 0.884 & 0.782 & 0.000 & 0.035 \\
E & 1.399 & 1.979 & 2.805 & 3.399 & 2.111 & 0.807 & 0.000 & 0.115 \\
ENE & 1.487 & 2.021 & 3.032 & 2.906 & 2.057 & 0.791 & 0.000 & 0.178 \\
NE & 0.952 & 1.863 & 3.103 & 3.359 & 2.181 & 0.914 & 0.000 & 0.159 \\
NNE & 0.898 & 0.997 & 1.398 & 2.784 & 2.022 & 0.838 & 0.000 & 0.061 \\
\hline
\end{tabular}


Radiological Dose Assessment

\section{Table C-7B. Arithmetic Average Wind Speeds (Wind Towards).}

\begin{tabular}{lccccccc}
\hline & \multicolumn{7}{c}{ Pasquill Stability Class } \\
\cline { 2 - 8 } Direction & A & B & C & D & E & F & G \\
\hline N & 0.965 & 1.325 & 2.785 & 2.806 & 2.094 & 1.035 & 0.000 \\
NNW & 0.954 & 2.700 & 3.560 & 2.644 & 1.796 & 1.028 & 0.000 \\
NW & 1.014 & 2.420 & 2.444 & 1.875 & 1.774 & 1.137 & 0.000 \\
WNW & 0.971 & 1.438 & 2.660 & 1.556 & 1.697 & 1.158 & 0.000 \\
W & 1.072 & 1.300 & 1.750 & 1.489 & 1.385 & 1.098 & 0.000 \\
WSW & 1.496 & 1.827 & 2.196 & 2.136 & 1.296 & 0.901 & 0.000 \\
SW & 1.424 & 2.293 & 3.293 & 3.367 & 1.687 & 1.046 & 0.000 \\
SSW & 1.790 & 2.474 & 3.314 & 3.975 & 1.460 & 1.100 & 0.000 \\
S & 1.568 & 2.142 & 3.472 & 5.075 & 1.100 & 0.986 & 0.000 \\
SSE & 1.302 & 1.972 & 2.804 & 3.545 & 1.500 & 1.015 & 0.000 \\
SE & 1.341 & 1.620 & 1.700 & 2.460 & 1.300 & 0.838 & 0.000 \\
ESE & 1.651 & 2.283 & 3.500 & 4.780 & 1.533 & 0.895 & 0.000 \\
E & 1.744 & 2.426 & 3.691 & 4.562 & 2.930 & 1.006 & 0.000 \\
ENE & 1.754 & 2.483 & 3.550 & 8.643 & 2.647 & 0.970 & 0.000 \\
NE & 1.172 & 2.169 & 3.598 & 4.617 & 2.789 & 1.164 & 0.000 \\
NNE & 1.080 & 1.487 & 1.829 & 3.808 & 2.623 & 1.035 & 0.000 \\
\hline
\end{tabular}


Radiological Dose Assessment

Table C-7C. Frequencies Of Stability Classes (Wind Towards).

\begin{tabular}{lccccccc}
\hline & \multicolumn{7}{c}{ Pasquill Stability Class } \\
\cline { 2 - 8 } Direction & A & B & C & D & E & F & G \\
\hline N & 0.0501 & 0.0118 & 0.0383 & 0.3569 & 0.2301 & 0.3127 & 0.0000 \\
NNW & 0.0402 & 0.0062 & 0.0464 & 0.3127 & 0.2105 & 0.3839 & 0.0000 \\
NW & 0.0263 & 0.0094 & 0.0301 & 0.3233 & 0.2594 & 0.3515 & 0.0000 \\
WNW & 0.0336 & 0.0128 & 0.0080 & 0.3040 & 0.3568 & 0.2848 & 0.0000 \\
W & 0.0611 & 0.0293 & 0.0342 & 0.2787 & 0.2225 & 0.3741 & 0.0000 \\
WSW & 0.0799 & 0.0521 & 0.0799 & 0.2951 & 0.1840 & 0.3090 & 0.0000 \\
SW & 0.0822 & 0.0644 & 0.2244 & 0.4422 & 0.0667 & 0.1200 & 0.0000 \\
SSW & 0.1818 & 0.1329 & 0.2238 & 0.2657 & 0.0524 & 0.1434 & 0.0000 \\
S & 0.3193 & 0.1303 & 0.1933 & 0.2521 & 0.0126 & 0.0924 & 0.0000 \\
SSE & 0.3377 & 0.1656 & 0.1788 & 0.1325 & 0.0530 & 0.1325 & 0.0000 \\
SE & 0.5290 & 0.1812 & 0.0797 & 0.0362 & 0.0217 & 0.1522 & 0.0000 \\
ESE & 0.3564 & 0.1626 & 0.1003 & 0.2872 & 0.0208 & 0.0727 & 0.0000 \\
E & 0.1472 & 0.1316 & 0.1772 & 0.3658 & 0.1264 & 0.0518 & 0.0000 \\
ENE & 0.0382 & 0.0402 & 0.1696 & 0.4765 & 0.2259 & 0.0496 & 0.0000 \\
NE & 0.0242 & 0.0121 & 0.0332 & 0.5343 & 0.3250 & 0.0732 & 0.0000 \\
NNE & 0.0295 & 0.0157 & 0.0275 & 0.4086 & 0.3281 & 0.1906 & 0.0000 \\
\hline TOTAL & $\mathbf{0 . 0 8 9 9}$ & $\mathbf{0 . 0 5 4 1}$ & $\mathbf{0 . 1 0 1 2}$ & $\mathbf{0 . 3 8 3 5}$ & $\mathbf{0 . 2 1 1 7}$ & $\mathbf{0 . 1 5 9 6}$ & $\mathbf{0 . 0 0 0 0}$ \\
\hline
\end{tabular}




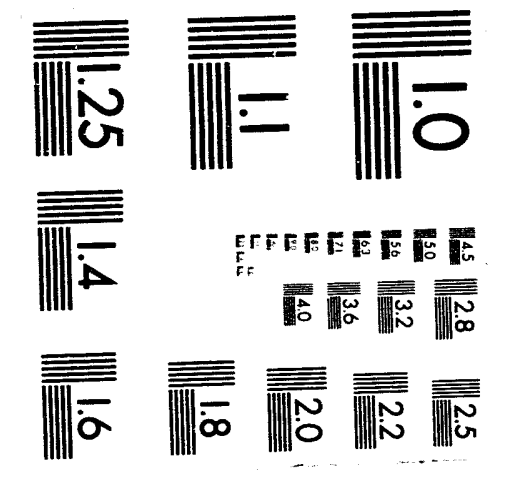



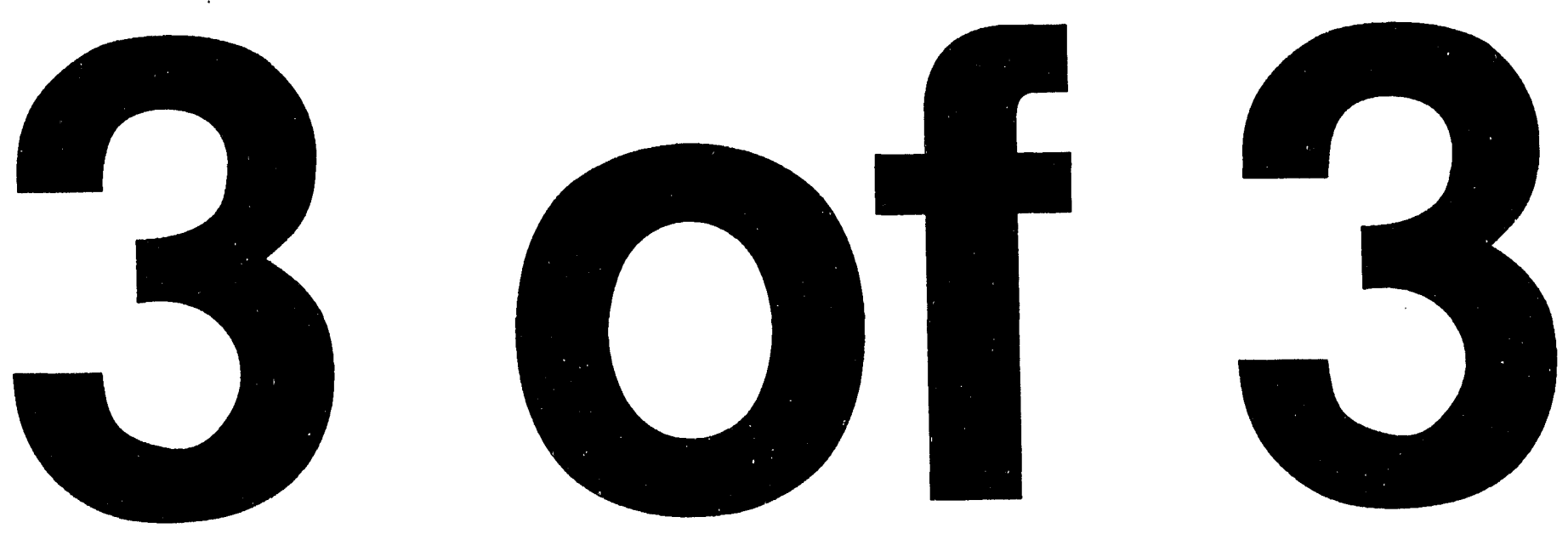
Appendix D Radiation Protection Standards

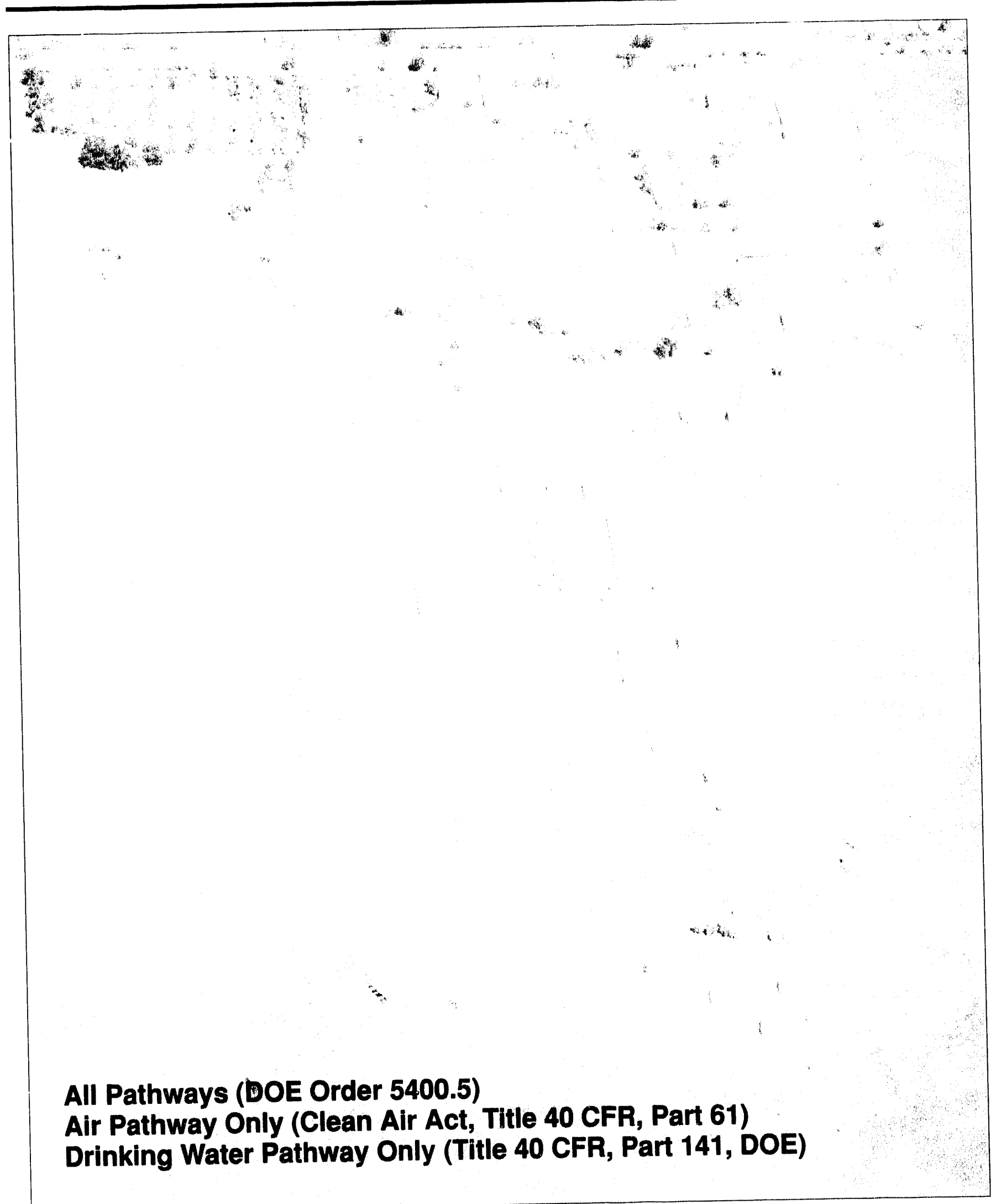




\section{Radiation Protection Standards}

SNL/California conducts its operations in accordance with applicable Federal, State, and local environmental laws and regulations. In addition, DOE has established radiation protection standards for the public and the environment, which are contained in DOE Orders pursuant to the Atomic Energy Act.

Radiation protection standards for the public have been established by DOE to protect public health. Protection of the public is accomplished by limiting radiation doses received by individuals residing in uncontrolled areas (i.e., areas accessible to the public) resulting from DOE operations. In other words, these standards are based on acceptable risk to members of the public.

\section{All Pathways (DOE Order 5400.5)}

Environmental protection program requirements for DOE operations are established in DOE Order 5400.1, General Environmental Protection Program. Radiation protection standards are provided in DOE Order 5400.5, Radiation Protection of the Public and the Environment. Order 5400.5 limits the annual EDE to any member of the public to $100 \mathrm{mrem} /$ year ( $1 \mathrm{mSv} / \mathrm{yr}$.). This limit is based on the dose to the maximally exposed individual in an uncontrolled area from all emission sources and all exposure pathways. It is consistent with the recommendations of the International Commission on Radiological Protection and the National Council on Radiation Protection and Measurements. The DOE derived concentration guide (DCG) lists concentrations of radionuclides in water and air that could be continuously consumed or inhaled (365 days/yr.) and not exceed the DOE primary radiation protec- tion standard to the public ( $100 \mathrm{mrem} / \mathrm{yr}$. effective dose equivalent). Table D-1 contains the DCG pertinent to this report.

In addition to these quantitative standards, the overriding DOE policy is that exposures to the public and emissions to the environment shall be maintained as low as reasonably achievable (ALARA).

\section{Air Pathway Only (Clean Air Act, Title 40 CFR, PART 61)}

DOE facilities are also required to comply with EPA standards for radiation protection. On December 15, 1989, the EPA issued its final Rule on National Emission Standards for Hazardous Air Pollutants (NESHAPs) for Radionuclides. This Rule mandates that air emissions from DOE facilities shall not cause any individual in the public to receive in any year an EDE of greater than 10 mrem $(0.1 \mathrm{mSv})$. Table D-2 summarizes the public radiation protection standards that are applicable to DOE facilities.

\section{Drinking Water Pathway Only (Title 40 CFR, PART 141, DOE ORDER 5400.5)}

Radionuclide concentrations in DOE-operated public drinking water supplies shall not cause persons consuming the water to receive an effective dose equivalent greater than $4 \mathrm{mrem}(0.04 \mathrm{mSv})$ in a year. DOE activities shall not cause private or public drinking water systems downstream of the facility discharge to exceed the radiological drinking water limits in Title 40 CFR, Part 141.

Table D-3 lists the State of California (1977) limits for maximum contaminant levels (MCLs) for public drinking water supplies.

SNL/CA Site Environmental Report for 1992 


\section{Radiation Protection Standards}

Table D-1. DOE Derived Concentration Guide for Protection of the Public.

\begin{tabular}{ccccc}
\hline & \multicolumn{2}{c}{ Concentration in Air } & \multicolumn{2}{c}{ Concentration in Water } \\
\hline Nuclide & $(\mu \mathrm{Cl} / \mathrm{mL})$ & $(\mathrm{Bq} / \mathrm{mL})$ & $(\mu \mathrm{Cl} / \mathrm{mL})$ & $(\mathrm{Bq} / \mathrm{mL})$ \\
\hline${ }^{3} \mathrm{H}$ & $1 \times 10^{-7}$ & $4 \times 10^{-3}$ & $2 \times 10^{-3}$ & 74 \\
${ }^{235} \mathrm{U}$ & $1 \times 10^{-13}$ & $3.7 \times 10^{-9}$ & $6 \times 10^{-7}$ & $2.2 \times 10^{-2}$ \\
${ }^{238} \mathrm{U}$ & $1 \times 10^{-13}$ & $3.7 \times 10^{-9}$ & $6 \times 10^{-7}$ & $2.2 \times 10^{-2}$ \\
\hline
\end{tabular}

Table D-2. Public Radiation Protection Standards for DOE Facilities.

\begin{tabular}{lccc}
\hline \multicolumn{1}{c}{ Exposure $^{\text {a }}$} & \multicolumn{2}{c}{$\begin{array}{c}\text { Effective Dose Equivalent } \\
\text { (mrem/year) }\end{array}$} & $\begin{array}{c}\text { (mSv/year) } \\
\text { (megulation }\end{array}$ \\
\hline All pathways $^{c}$ & 100 & 1 & DOE Order 5400.5 \\
Air pathway only $^{d}$ & 10 & 0.1 & Federal Clean Air Act \\
\hline
\end{tabular}

aln keeping with DOE policy, exposures shall be kept to as low as reasonably achievable (ALARA) levels.

${ }^{b}$ As defined by DOE, effective dose equivalent includes both the effective dose equivalent from external radiation and the committed effective dose equivalent from ingestion and inhalation during the calendar year.

CThese limits are from DOE Order 5400.5, and are consistent with the recommendations of the International Commission on Radiological Protection.

dThese limits are from the EPA's regulations established under the Clean Air Act, National Emissions Standards for Hazardous Air Pollutants (NESHAPs) Rule for Radionu,slides (Title 40 CFR, Part 61, Subpart H).

Table D-3. California Maximum Contaminant Levels (MCLs) for Public Water Supplies. ${ }^{a}$

\begin{tabular}{lcc}
\hline \multicolumn{1}{c}{ Radioactivity } & \multicolumn{2}{c}{ Concentration in Drinking Water } \\
\hline $\begin{array}{l}\text { Gross alpha particle activity } \\
\text { (including }{ }^{226} \mathrm{Ra} \text { but excluding Rn and U) }\end{array}$ & $15 \mathrm{pCi} / \mathrm{L}$ or $1.5 \times 10^{-8} \mathrm{mCi} / \mathrm{mL}$ & $0.56 \mathrm{~Bq} / \mathrm{L}$ \\
Gross beta particle activity & $50 \mathrm{pCi} / \mathrm{L}$ or $5.0 \times 10^{-8} \mathrm{mCi} / \mathrm{mL}$ & $1.85 \mathrm{~Bq} / \mathrm{L}$ \\
Tritium & $\begin{array}{c}20,000 \mathrm{pCi} / \mathrm{L} \text { or } 2.0 \times 10^{-5} \\
\mathrm{mCi} / \mathrm{mL}\end{array}$ & $740 \mathrm{~Bq} / \mathrm{L}$ \\
\hline
\end{tabular}

aThese limits have been established by the State of California (1977) as safe levels of radionuclides in drinking water consumed by the general public. 
Appendix E

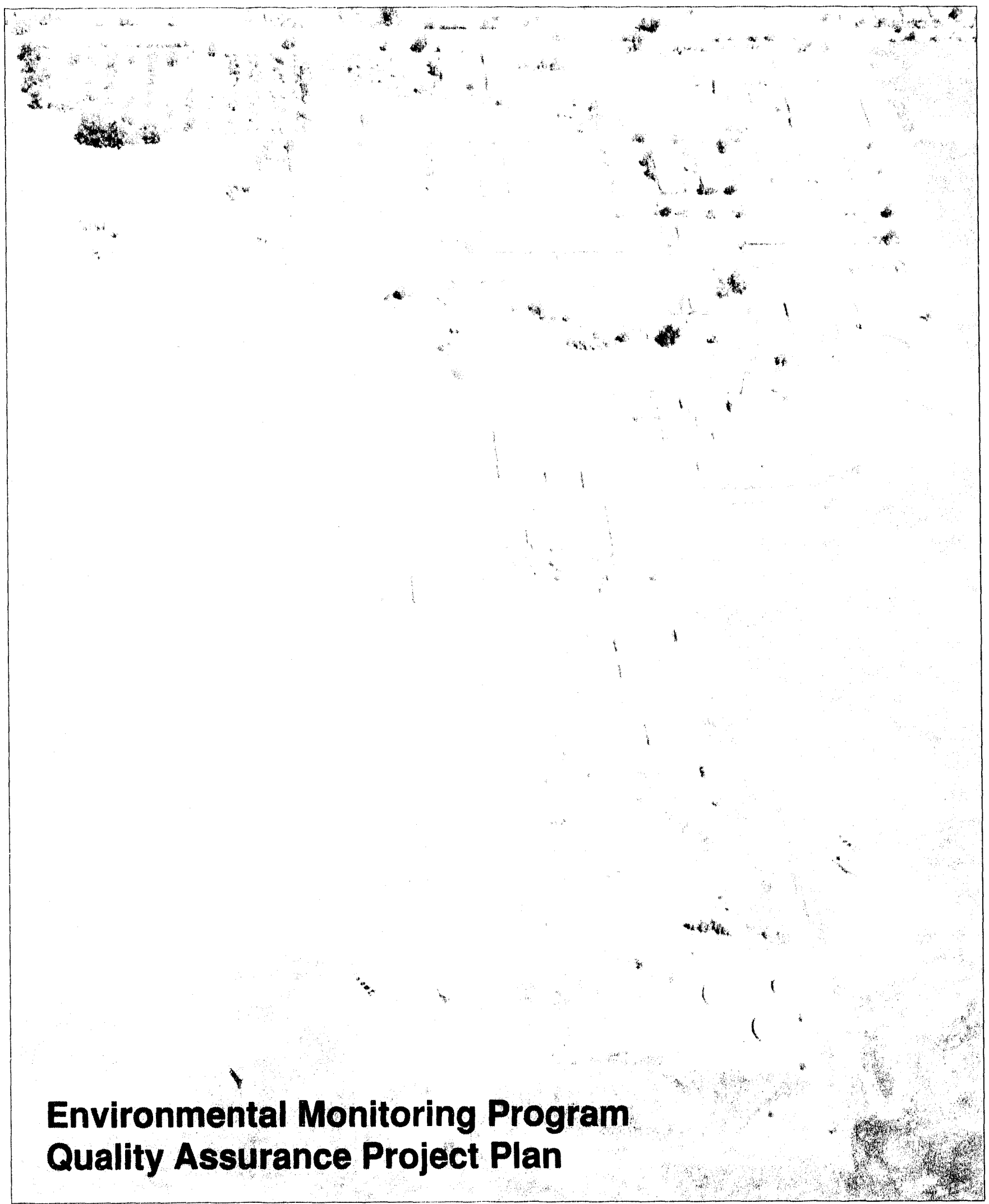




\section{SANDIA REPORT}

SAND93-8010 • UC-402

Unlimited Release

Printed June 1993

\section{Environmental Monitoring Program Quality Assurance Project Plan}

R. C. Holland

Prepared by

Sandia National Laboratories

Albuquerque, New Mexico 87185 and Livermore, California 94551

for the United States Department of Energy

under Contract DE-AC04-76DP00789 


\section{Appendix E}

E-2 SNL/CA Site Environmental Report for 1992 
SAND93-8010

UC-402

Unlimited Release

Printed June 1993

\title{
ENVIRONMENTAL MONITORING PROGRAM QUALITY ASSURANCE PROJECT PLAN
}

\author{
Robert C. Holland \\ Environmental Protection Department \\ Sandia National Laboratories/California
}

\begin{abstract}
The Quality Assurance Project Plan (QAPP) is intended to document the quality assurance of the Environmental Monitoring Program. The Quality Assurance Project Plan has two parts and is written to become a chapter in the Environmental Monitoring Plan. Part A describes the management responsibilities and activities performed to assure the quality of the Environmental Monitoring Program. Part B covers the documentation requirements for changes in the Monitoring Program, and provides details on control of the design and implementation of quality assurance activities.
\end{abstract}




\section{Appendix E}

Approved by:

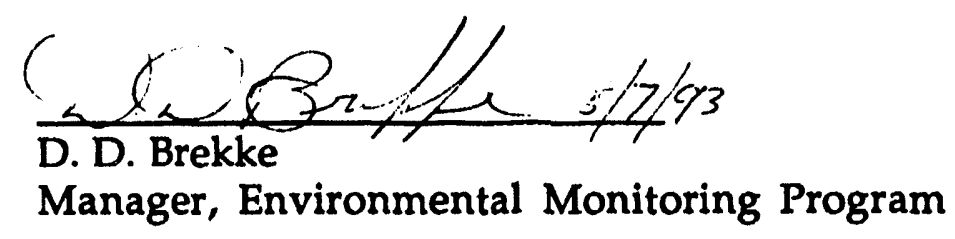

Approved by:

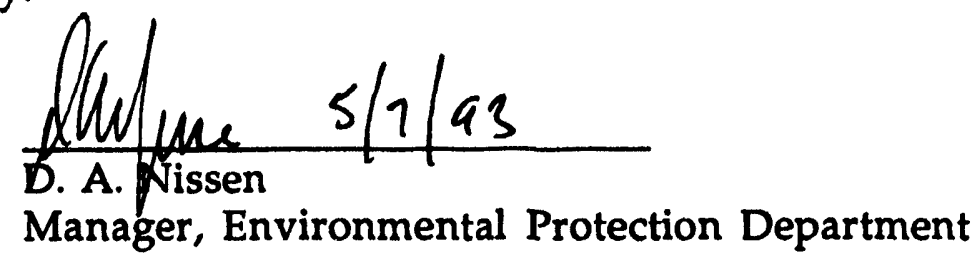

Approved by:

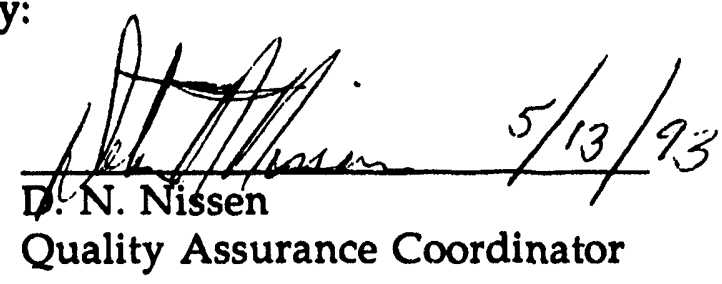




\section{CONTENTS}

Environmental Monitoring Program Quality Assurance Project Plan................................7

Part A - Management Systems.....................................................................................................7

Management Commitment and Organization ........................................................

Quality Assurance Program Description..................................................................9

Personnel Training and Qualification ..................................................................10

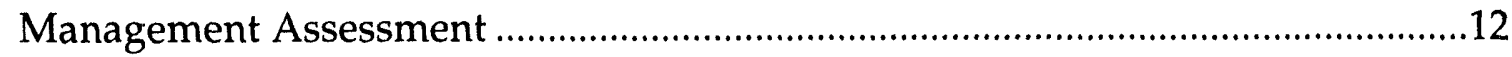

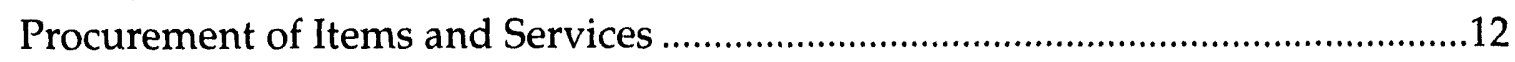

Document Control and Records .........................................................................12

Use of Computer Hardware and Software...........................................................13

Work Processes and Operations.........................................................................13

Quality Improvement ....................................................................................14

Part B - Technical Description and Reporting Requirements..........................................15

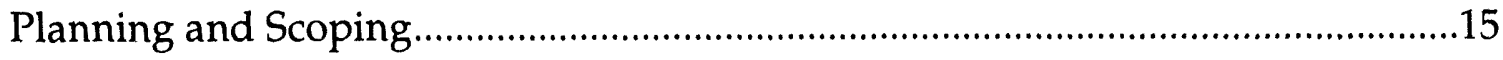

Design of Data Collection Activities .................................................................16

Implementation of Planned Operations ................................................................16

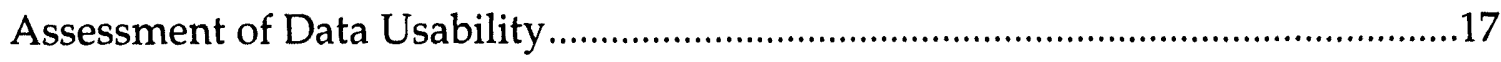

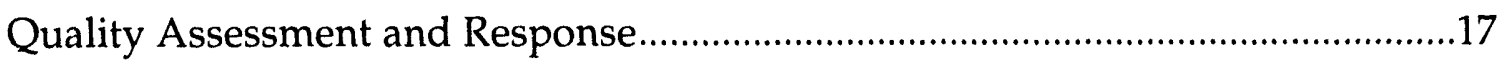

References...................................................................................................................................18

Glossary and List of Acronyms ...............................................................................................19 


\section{Appendix E}

E-6 SNL/CA Site Environmental Report for 1992 


\section{ENVIRONMENTAL MONITORING PROGRAM QUALITY ASSURANCE PROJECT PLAN}

The Environmental Monitoring Program ensures that SNL/California complies with Federal, State, and local regulations, and DOE Orders governing emissions to the environment. The Program monitors airborne emissions sources, wastewater discharges, and the environment of the Laboratory and nearby vicinity to verify compliance. The program also provides training to line organizations on issues concerning discharges to the air and sanitary sewer.

The Environmental Monitoring Program is part of the Environmental Protection Department within the Center for Environment, Safety \& Health (ES\&H) and Facilities. The Environmental Monitoring Plan, a document required by DOE Order 5400.1 that must be reviewed annually, describes the Environmental Monitoring Program in detail.1,2

The Quality Assurance Project Plan (QAPP) is intended to document the quality assurance of the Environmental Monitoring Program, following guidance presented in DOE Order 5700.6C and ANSI/ASQC-E4-19xx.3,4 The Quality Assurance Project Plan has two parts and is written to become a chapter within the Environmental Monitoring Plan. Part A describes the management responsibilities and activities performed to assure the quality of the Environmental Monitoring Program. Part B covers the documentation requirements for changes in the Monitoring Program, and provides details on control of the design and implementation of quality assurance activities.

\section{PART A - MANAGEMENT SYSTEMS Management Commitment and Organization}

The manager of the Environmental Protection Department is fully committed to implemienting the Center for ES\&H and Facilities Quality Assurance Management Plan (QAMP). ${ }^{5}$ Pursuant to this commitment, he directed development of this QAPP to implement the QAMP within the Environmental Monitoring Program.

The Department Manager retains ultimate responsibility for implementing this Quality Assurance Project Plan (QAPP).The Environmental Monitoring Program Manager is responsible for ensuring the application of QAPP provisions to daily Program activities.

The primary responsibility, however, for the quality of the work within the Environmental Monitoring Program rests with the individual performing the work. No individual will work on a project for which he or she is not qualified. Each individual is responsible for understanding and complying with the quality assurance requirements for any task performed.

Figure 1 shows the organizational structure of the Environmental Monitoring Program and its relationship to the Environmental Protection Department.

The Environmental Monitoring Program also interfaces with other organizations within and outside of Sandia: 


\section{Appendix E}

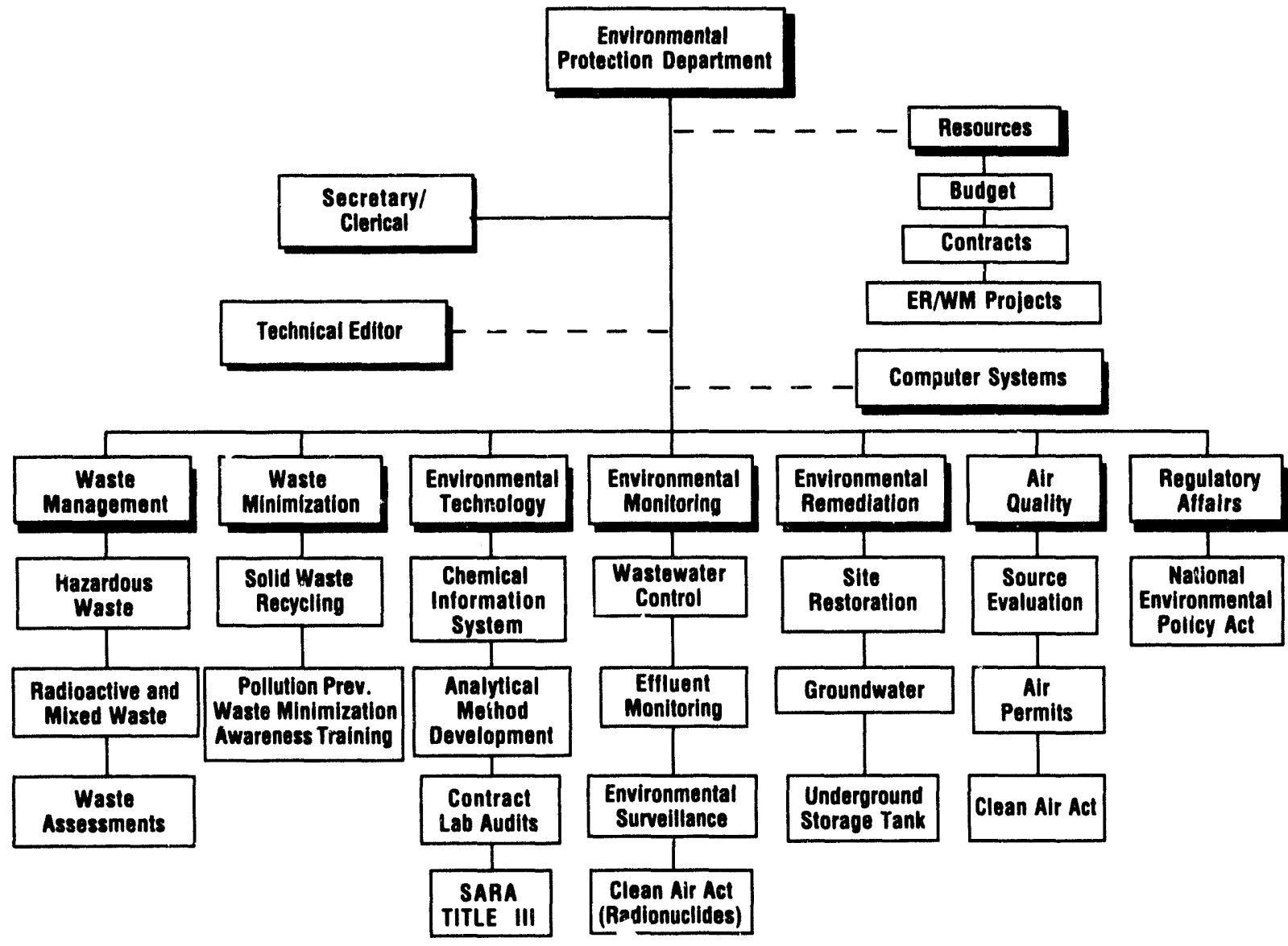

Figure 1. Organizational structure of the Environmental Protection Department.

- Lawrence Livermore National Laboratory (LLNL) conducts most of the off-site environmental monitoring. Monitoring Program personnel receive LLNL off-site monitoring data to review ongoing environmental quality and to prepare the annual Site Environmental Report.

- The on-site Atmospheric Release Advisory Capability (ARAC) system provides meteorological data as inputs to computer dose modeling programs.

- The Environmental Technology Program of the Environmental Protection Department performs metals analyses of the wastewater samples collected from the Liquid Effluent Control Systems (LECS).

- The ES\&H and Facilities Management Center Quality Assurance Organization 


\section{Appendix E}

provides independent oversight for and assessment of the implementation of this QAPP.

- Off-site analytical laboratories analyze environmental samples and support sample collection activities.

\section{Quality Assurance Program Description}

The Quality Assurance Program for the Environmental Monitoring Program includes:

- The ES\&H and Facilities Center QAMP and its Implementing Procedures (IPs), and

- This QAPP and the Operating Procedures written to support its implementation.

The QAMP covers quality assurance traits common to all functions of the Center for ES\&H and Facilities. These standardized functions include management assessment, personnel qualifications and training, procurement policies, and document control.

This QAPP applies to all program specific activities necessary to produce the desired type and quality of environmental monitoring data. These activities include: sample collection, data validation, data manipulations, equipment calibration, dose calculations, and reports.

The Operating Procedures will be established in accordance with IP 4.02, Development of Operating Procedures. ${ }^{6}$ The procedures will cover the following areas:

- Data analysis

- Meteorological monitoring

- Direct radiation monitoring

- Sewer monitoring

- Liquid Effluent Control System monitoring (LECS)

- Stormwater runoff monitoring

- Annual off-site radiological dose assessment

- Sampling process wastewater for federal categorical pretreatment regulation compliance.

Planning documents and operating procedures, as described in the QAMP and this QAPP, will be developed before any new activity affecting quality is undertaken. These documents and procedures serve to ensure the data produced are of the required type and accuracy commensurate with the importance of the activity.

\section{Personnel Training and Qualification}

The qualifications and training of Environmental Monitoring Program personnel conform to the requirements of QAMP Section 2, and IP 2.01, Qualifications and Training. ${ }^{7}$ This IP requires that training documentation or training exemption documentation be maintained for all personnel and procedures. Table 1 lists job descriptions and qualifications within the Environmental Monitoring Program. 


\section{Appendix E}

Table 1. Job Descriptions and Qualifications

\begin{tabular}{|c|c|}
\hline Position & Qualifications \\
\hline $\begin{array}{l}\text { Environmental Monitoring Program } \\
\text { Manager } \\
\text { Responsible for the overall management of the } \\
\text { Environmental Monitoring Program, including } \\
\text { sampling strategies and methods, preparing } \\
\text { required reports, interacting with regulatory } \\
\text { agencies, and informing management of } \\
\text { Environmental Monitoring activities. }\end{array}$ & $\begin{array}{l}\text { Master's degree in Environmental Science, } \\
\text { Biology, Health Physics, or related biological or } \\
\text { physical science. } \\
\text { Minimum of five years' experience in environmental } \\
\text { monitoring, meteorological monitoring, radiological } \\
\text { dose assessment, or related environmental field. }\end{array}$ \\
\hline $\begin{array}{l}\text { Task Leader } \\
\text { Responsible for a given task or a particular project } \\
\text { Responsibilities include performing all technical } \\
\text { aspects of the given task in compliance with DOE } \\
\text { Orders, Federal, State, or local regulations, and } \\
\text { Sandia procedures, as appropriate. }\end{array}$ & $\begin{array}{l}\text { Bachelor's degree in Environmental Science, } \\
\text { Biology, Health Physics, or related biological or } \\
\text { physical science, or equivalent experience. } \\
\text { Minimum of two years' experience in environment } \\
\text { monitoring, meteorological monitoring, radiologica } \\
\text { dose assessment, or related environmental field. }\end{array}$ \\
\hline $\begin{array}{l}\text { Task Support } \\
\text { Responsible for assisting Task Leaders and the } \\
\text { Program Manager as assigned. }\end{array}$ & $\begin{array}{l}\text { Bachelor's degree in Environmental Science, } \\
\text { Biology, Health Physics, or related biological or } \\
\text { physical science, or equivalent experience. } \\
\text { Minimum of two years' experience in environment } \\
\text { monitoring, meteorological monitoring, radiological } \\
\text { dose assessment, or related environmental field. } \\
\end{array}$ \\
\hline $\begin{array}{l}\text { Technical Support } \\
\text { Responsible for field monitoring, sample collecting } \\
\text { handling, storage, shipping to appropriate analytic } \\
\text { facilities, analyzing report verification, and } \\
\text { maintaining sampling equipment. }\end{array}$ & $\begin{array}{l}\text { Two-year technical degree, or the equivalent. } \\
\text { Minimum of two years' experience in either } \\
\text { lenvironmental sampling or installing and } \\
\text { maintaining mechanical or electrical systems. }\end{array}$ \\
\hline
\end{tabular}

Table 2. Mandatory Training Requirements for Environmental Monitoring Personnel

\begin{tabular}{|l|l|}
\hline \multicolumn{1}{|c|}{ Training } & \multicolumn{1}{c|}{ Frequency } \\
\hline Radiation Safety Orientation & Biannual \\
\hline Fire Extinguisher Awareness & Annual \\
\hline Occurrence Reporting Procedures & Biannual \\
\hline Lockout/Tagout Awareness & Annual \\
\hline Emergency Preparedness Awareness & Annual \\
\hline ES\&H Rights Self-Study & Annual \\
\hline Quality Assurance Project Plan Orientation & Upon hire, or changes to the QAPP \\
\hline
\end{tabular}




\section{Appendix E}

Table 3. Individual Training Requirements for Environmental Monitoring Personnel (assigned as appropriate)

\begin{tabular}{|l|l|}
\hline \multicolumn{1}{|c|}{ Training } & \multicolumn{1}{|c|}{ Frequency } \\
\hline Data Validation and Verification & Upon assignment of responsibility or update of the procedure. \\
\hline Control of the LECS & Upon assignment of responsibility or update of the procedure. \\
\hline Operation of the B. 913 LECS & Upon assignment of responsibility or update of the procedure. \\
\hline Operation of the B. 906 LECS & Upon assignment of responsibility or update of the procedure. \\
\hline Operation of the B. 910 LECS & Upon assignment of responsibility or update of the procedure. \\
\hline Operation of the B. 968 LECS & Upon assignment of responsibility or update of the procedure. \\
\hline TLD Collection & Upon assignment of responsibility or update of the procedure. \\
\hline $\begin{array}{l}\text { Meteorological Program } \\
\text { Performance Checks }\end{array}$ & Upon assignment of responsibility or update of the procedure. \\
\hline Data Analysis & Upon assignment of responsibility or update of the procedure. \\
\hline Sanitary Sewer Outfall Monitoring & Upon assignment of responsibility or update of the procedure. \\
\hline Dose Assessment & Upon assignment of responsibility or update of the procedure. \\
\hline Stormwater Runoff Monitoring & Upon assignment of responsibility or update of the procedure. \\
\hline $\begin{array}{l}\text { Federal Categorical Process } \\
\text { Monitoring }\end{array}$ & Upon assignment of responsibility or update of the procedure. \\
\hline
\end{tabular}

In accordance with IP 2.01, the Environmental Monitoring Program Manager is responsible for assuring and documenting that Program personnel receive appropriate training for their duties. The Program Manager maintains training records for all personnel and keeps copies for quality assurance records, as specified in IP 4.04, Records Management. ${ }^{8}$ Table 2 shows the training required of all Program personnel. Table 3 shows additional training that may be required of individual Monitoring Program personnel, depending on their assigned duties.

\section{Management Assessment}

The Director of the Center for ES\&H and Facilities is responsible for management assessment of the operations of the Environmental Monitoring Program. These duties and responsibilities are detailed in IP 9.01, Management Assessment. ${ }^{9}$

Environmental Monitoring Program personnel are responsible for cooperating with the management assessment teams. This cooperation includes allowing access to files and equipment, and permitting physical inspection of work activities in progress.

\section{Procurement of Items and Services}

IP 7.01, Procurement, describes the steps necessary to assure the quality of purchased items and services. ${ }^{10}$ 


\section{Appendix E}

Typical items and services procured by the Monitoring Program include:

- Laboratory analyses of environmental samples;

- Calibration services for meteorological sensors;

- Flow measuring, $\mathrm{pH}$ measuring, and proportional sample collecting equipment for sewer monitoring; and

- Consulting services for specialized tasks.

IP 7.01 requires that quality assurance requirements for procurements be documented to ensure that these items and services meet the quality requirements of the Monitoring Program.

\section{Document Control and Records}

The ES\&H and Facilities Management Center Document Control System controls Documerits and Records generated by the Monitoring Program, as detailed in IP 4.03, Document Control , and IP 4.04, Records Management. ${ }^{11,8}$

The following items, produced by the Environmental Monitoring Program, are considered quality assurance records. Therefore, they are subject to the conditions specifying retrievability, safeguards, and retention time.

- All data generated by environmental sampling.

- All chain-of-custody forms, field notebooks, and other documents associated with environmental sampling.

- All documents specifying the design or rationale of environmental monitoring systems.

- All Operating Procedures, both current and superseded.

- All reports, plans, and other forms of data transmittal, intended for either internal or external purposes.

\section{Use of Computer Hardware and Software}

The Environmental Monitoring Program uses only standard hardware and software. No software is developed specifically for the Monitoring Program.

\section{Work Processes and Operations}

Work processes and operations include all Monitoring Program activities that affect the quality of the data produced. These activities include: sampling, dose modeling, data analysis, and equipment calibrations. All Operating Procedures are developed in accordance with IP 4.02, Development of Operating Procedures. ${ }^{12}$ The following areas are addressed:

- Sampling. Environmental sampling activities are described in Operating Procedures (as specified in Section 2). The Operating Procedures specify necessary quality control checks and acceptance criteria.

- Dose Modeling. Dose modeling activities are described in an Operating Procedure. This procedure includes necessary quality control checks and acceptance criteria. 


\section{Appendix E}

- Data Analysis. Data manipulation is described in an Operating Procedure. This procedure includes: data validation and verification, data quality objectives (developed in accordance with IP 5.04, Data Quality Objectives Process), ${ }^{13}$ data tracking and trending, quality control data analysis, developing summary statistics, and comparing data to specified regulatory limits.

- Equipment Calibrations. Calibration of measuring and test equipment is described in Operating Procedures. These procedures follow the guidance provided in IP 5.03, Control of Measuring and Test Equipment. ${ }^{14}$ These procedures incorporate guidance from the equipment manufacturers as appropriate. The procedures include acceptance criteria. Calibrations are traceable to a national standard (such as National Iristitute for Standards and Technology-NIST).

The Center for ES\&H and Facilities Quality Assurance organization independently assesses the implementation of Quality Assurance for work processes, in accordance with IP 10.01, Independent Assessment. ${ }^{9}$

The ES\&H Assessments Department (Organization 7001) performs independent technical assessments. These technical assessments use procedures developed by the ES\&H Assessments Department.

\section{Quality Improvement}

The Environmental Monitoring staff constantly strive to improve the quality of Program operations. Improvement is accomplished through the following actions:

- Management and Independent Assessments: Recommendations from both outside organizations and internal management assessments (see Part B, Section 5) are implemented as soon as is reasonably achievable. Recommendations are tracked in order to identify any trends adverse to quality.

- Design Reviews: All revisions or additions to the design of environmental monitoring operations receive peer review by a qualified individual and a management review up to the level of the Director, ES\&H and Facilities Management Center.

- Corrective Action: Necessary corrective actions (identified during Program assessments) are carried out in a timely fashion. These corrective actions are documented by memorandum to file. If the corrective action requires a change in the Monitoring Program, these changes will be documented as specified in Part B of this QAPP.

All personnel are encouraged to identify and correct problems. Staff are encouraged to offer ideas for improvement to the Monitoring Program.

Nonconforming data and equipment may be detected in two ways: 1) through routine inspections, calibrations, or usage; and 2) through management assessments. For the purposes of 


\section{Appendix E}

this QAPP, nonconformances are defined as deficiencies in procedure, characteristic, or documentation, which render the quality of an item unacceptable or indeterminate.

Disposition of nonconforming equipment is covered in the Operating Procedure for calibration of the equipment. This procedure also includes guidelines for use of data collected during the period when the equipment was not performing within specifications.

The disposition of nonconforming data (i.e., data that fails to meet established Data Quality Objectives) is covered in IP 5.01, Identification and Control of Technical Data, and OP-EM-9, Data Validation and Verification (see Part A, Sections 2 and 8).15,16

\section{PART B - TECHNICAL DESCRIPTION AND REPORTING REQUIREMENTS}

\section{Planning and Scoping}

The Environmental Monitoring Plan describes the Environmental Monitoring Program in detail, and includes the rationale for sampling, sampling procedures, analytical procedures, and previous data analysis. ${ }^{2}$ This document is required by DOE Order 5400.1 , must be reviewed annually and revised at least once every three years. The latest version of the Environmental Monitoring Plan reflects the current status of the Environmental Monitoring Program, and includes the final documentation on all changes.

Between revisions to the Environmental Monitoring Plan, Planning and Scoping Packages provide documentation for changes or additions to the Monitoring Program. The following revision of the Environmental Monitoring Plan includes all the changes described in the interim Planning and Scoping Packages.

Planning and Scoping Packages receive the same level of review as the Environmental Monitoring Plan, up to and including the Manager of the Environmental Protection Department.

Planning and Scoping Packages contain the following information:

- Rationale for the change(s)

- Requirements for the change

- References

- Regulations

- Best practices

- Data quality objectives (defined in IP 5.04)

- Description of the change

- Manpower required

- Equipment required

- Controlled conditions required (if any)

- Level of assessment tools required (audits, quality control checks, peer reviews, etc.) 


\section{Appendix E}

- Detailed identification of methods required

- New records required (if any) as quality assurance records

- Independent verification of the change-The Environmental Monitoring Program Manager selects a knowledgeable reviewer not directly involved in producing the change or addition. The review includes documented resolution of the reviewer's comments. A letter to the project file (included in the Planning and Scoping Package) documents the reviewer's qualifications.

All Planning and Scoping Packages are retained permanently as quality assurance records.

Planning and Scoping Packages also include procedures to document and control the conduct of new activities generated by these new changes.

\section{Design of Data Collection Activities}

The Environmental Monitoring Plan describes the design of environmental monitoring operations. Like Planning and Scoping packages, Design Packages provide for changes or additions to the design of the Monitoring Program between revisions to the Environmental Monitoring Plan. These design changes are also included in the next revision of the Environmental Monitoring Plan.

Design Packages receive the same level of review as the Environmental Monitoring Plan, up to and including the Manager of the Environmental Protection Department.

A Design Package is generated with Planning and Scoping documents and contains the following information:

- Sample type

- Sampling locations

- Sample handling and custody requirements

- Personnel qualifications and requirements

- Health and safety requirements

- Analytical methods-selection and requirements

- Analytical facility requirements

- Quality control sample requirements

- Analytical instrumentation and/or sampling equipment requirements

- New data reduction or validation requirements

- Review plans for system readiness prior to collecting samples

- Independent verification by a knowledgeable reviewer not directly involved in producing the new design.

All Design Packages are retained permanently as quality assurance records.

Design Packages include procedures to document and control the conduct of new activities created by these new changes. 


\section{Appendix E}

\section{Implementation of Planned Operations}

The Center for ES\&H and Facilities uses Implementing and Operating Procedures developed to support this QAPP. The Operating Procedures written to date include:

OP-EM-1 Sanitary Sewer Outfall

OP-EM-3 Control of the LECS

OP-EM-4 Operation of the B. 913 LECS

OP-EM-5 Operation of the B. 906 LECS

OP-EM-6 Operation of the B. 910 LECS

OP-EM-9 Data Validation and Verification

OP-EM-10 Quarterly Replacement of Perimeter Thermoluminescent Dosimeters

OP-EM-11 Response to Sewer Anomalies

OP-EM-12 Data Manipulation

\section{Assessment of Data Usability}

Data Quality Objectives (DQOs) are used to validate all environmental monitoring data per IP 5.04, Data Quality Objective Process.13 OP-EM-9, Data Validation and Verification, specifies verification and validation techniques. ${ }^{16}$ OP-EM-12, Data Manipulation, further specifies how to apply statistical methods correctly to monitoring data. The Operating Procedures include provisions for marking, segregating, and limiting the use of data that do not meet the DQOs, or fail the verification and validation tests.

All reports containing data generated by the Environmental Monitoring Program are independently reviewed to ensure the accuracy of the data. The Environmental Monitoring Program Manager must also approve these reports prior to release or distribution.

\section{Quality Assessment and Response}

The Quality Assurance Group in the ES\&H and Facilities Management Center is responsible for assessing the compliance of the Environmental Monitoring Program with this QAPP and with the ES\&H QAMP. These assessments are done in accordance with IP 10.01, Independent Assessment. ${ }^{9}$

Environmental Monitoring Program personnel cooperate fully with the Quality Assurance Group by providing access to records, personnel, and equipment. Program personnel are also required to provide timely responses to the deficiencies identified in the assessments.

The Environmental Protection Department Manager (or designee) performs Internal Management Assessments annually. Management assessments gauge how well the integrated quality assurance program works, and identify management problems that hinder the organization from achieving the required quality, safety, and environmental objectives. The results of these assessments and any follow-up action taken are documented and retained as quality assurance records. 


\section{REFERENCES}

1. U. S. Department of Energy (DOE) Order 5400.1, General Environmental Protection Program (November 1988).

2. R. C. Holland, Environmental Monitoring Plan, Sandia National Lab ratories, SAND918013 (1992).

3. DOE Order 5700.6C, Quality Assurance (1991).

4. American Society for Quality Control, Quality Assurance Program Requirements for Environmental Programs, ANSI/ASQC-E4-19x:x (review draft, 1991).

5. R. C. Holland, Quality Assurance Project Plan, Sandia National Laboratories (1992).

6. Implementing Procedure (IP) 4.02, Development of Operating Procedure, Sandia National Laboratories (1992).

7. IP 2.01, Qualifications and Training, Sandia National Laboratories (1992).

8. IP 4.04, Records Management, Sandia National Laboratories (1992).

9. IP 9.01, Management Assessment, Sandia National Laboratories (1992).

10. IP 7.01, Procurement, Sandia National Laboratories (1992).

11. IP 4.03, Document Control, Sandia National Laboratories (1992).

12. IP 4.02, Development of Operating Procedures, Sandia National Laboratories (1992).

13. IP 5.04, Data Quality Objectives Process, Sandia National Laboratories (1992).

14. IP 5.03, Control of Measuring and Test Equipment, Sandia National Laboratories (1992).

15. IP 5.01, Identification and Control of Technical Data, Sandia National Laboratories (1992).

16. Operating Procedure OP-EM-9, Data Validation and Verification, Sandia National Laboratories (1992). 


\section{Appendix E}

\section{GLOSSARY AND LIST OF ACRONYMS}

ARAC

\section{Calibration}

Data Validation and Verification

Data Manipulation

ES\&H

Implementing Procedures (IPs)

LECS

NIST

Nonconformance

Operating Procedures

QAMP

QAPP

Quality assurance records
Atmospheric Release and Advisory Capability. A DOE-operated emergency response system designed to provide meteorological modeling and dose calculation capabilities in the event of an accidental release of radionuclides at a DOE facility.

Testing or resetting a measuring instrument against a national standard (such as NIST) to ensure it is functioning correctly and accurately.

Actions taken to assure the quality of environmental monitoring data, such as .nalyses of: duplicate samples, spiked samples, blanks, and inter-laboratory comparison samples.

The development of summary statistics to describe environmental monitoring data sets. Statistical tests performed to compare environmental monitoring data sets to determine significant differences and trends.

Environment, Safety, and Health.

Procedures written to implement the provisions of the QAMP. The Environment, Safety \& Health and Facilities Management Center are required to apply these Implementing Procedures to all their operations. (See also Operating Procedures.)

Liquid Effluent Control System. Retention tanks designed to contain potentially contaminated, process wastewater until this wastewater can be analyzed and disposed of properly.

National Institute for Standards and Technology (formerly the National Bureau of Standards).

A deficiency in characteristic, documentation, or procedure that renders the quality of an item unacceptable or indeterminate. Examples of nonconformance include: physical defects, test failures, incorrect or inadequate documentation, and/or deviations from prescribed processing, inspection, or test procedures.

Procedures covering actual daily activities. Operating procedures also implement the provisions of the QAMP and this QAPP. (See Implementing Procedures.)

Quality Assurance Management Plan. The quality assurance document covering the operations of the Environmental Protection Department.

Quality Assurance Project Plan. A quality assurance document describing the specific quality assurance activities performed by the Environmental Protection Department to implement the provisions of the QAMP.

Documentation generated by Environmental Monitoring Program operations required by Federal, State, local regulation, or by DOE Order, and retained for a specific time. Storage conditions and methods may also be specified 

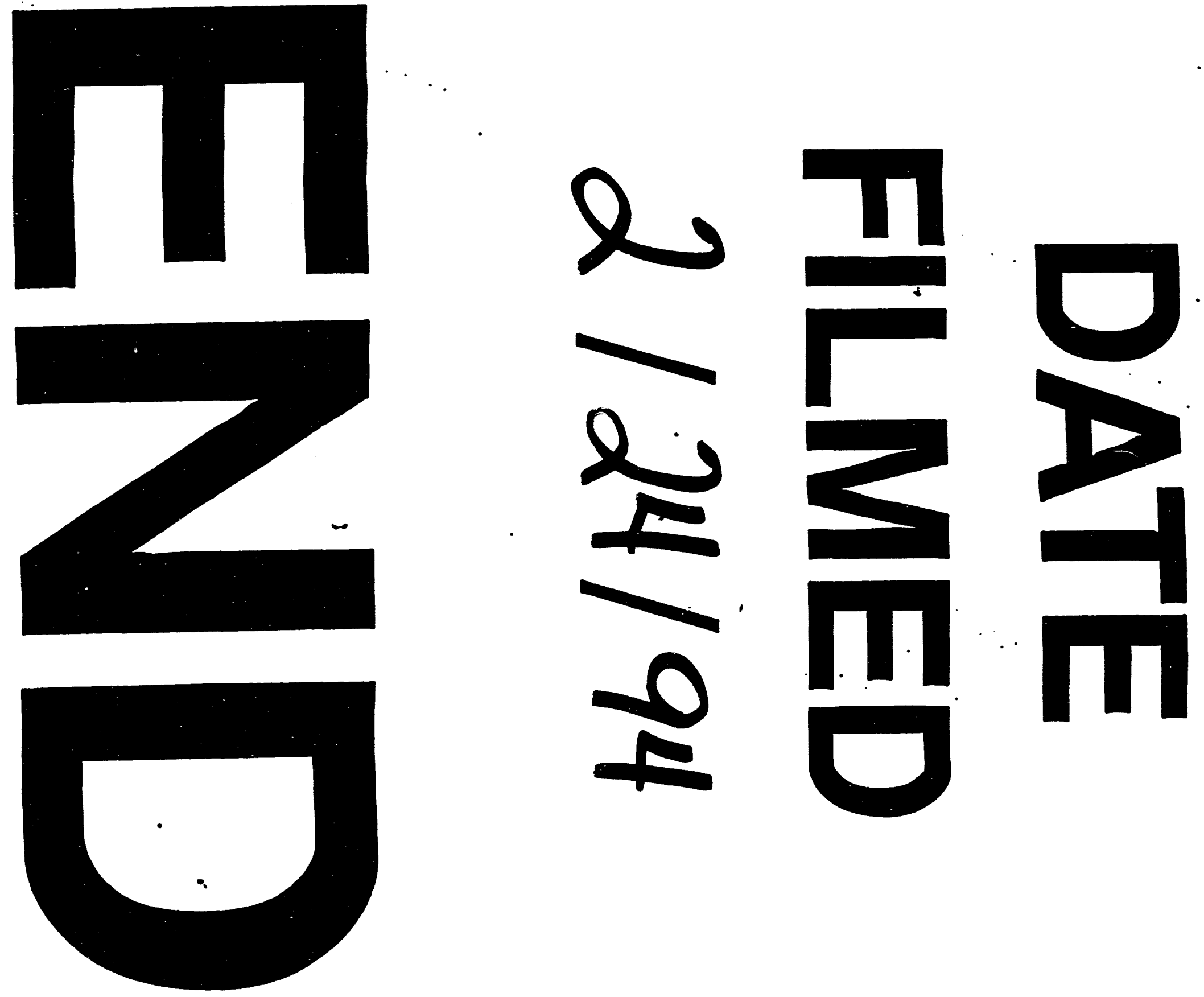


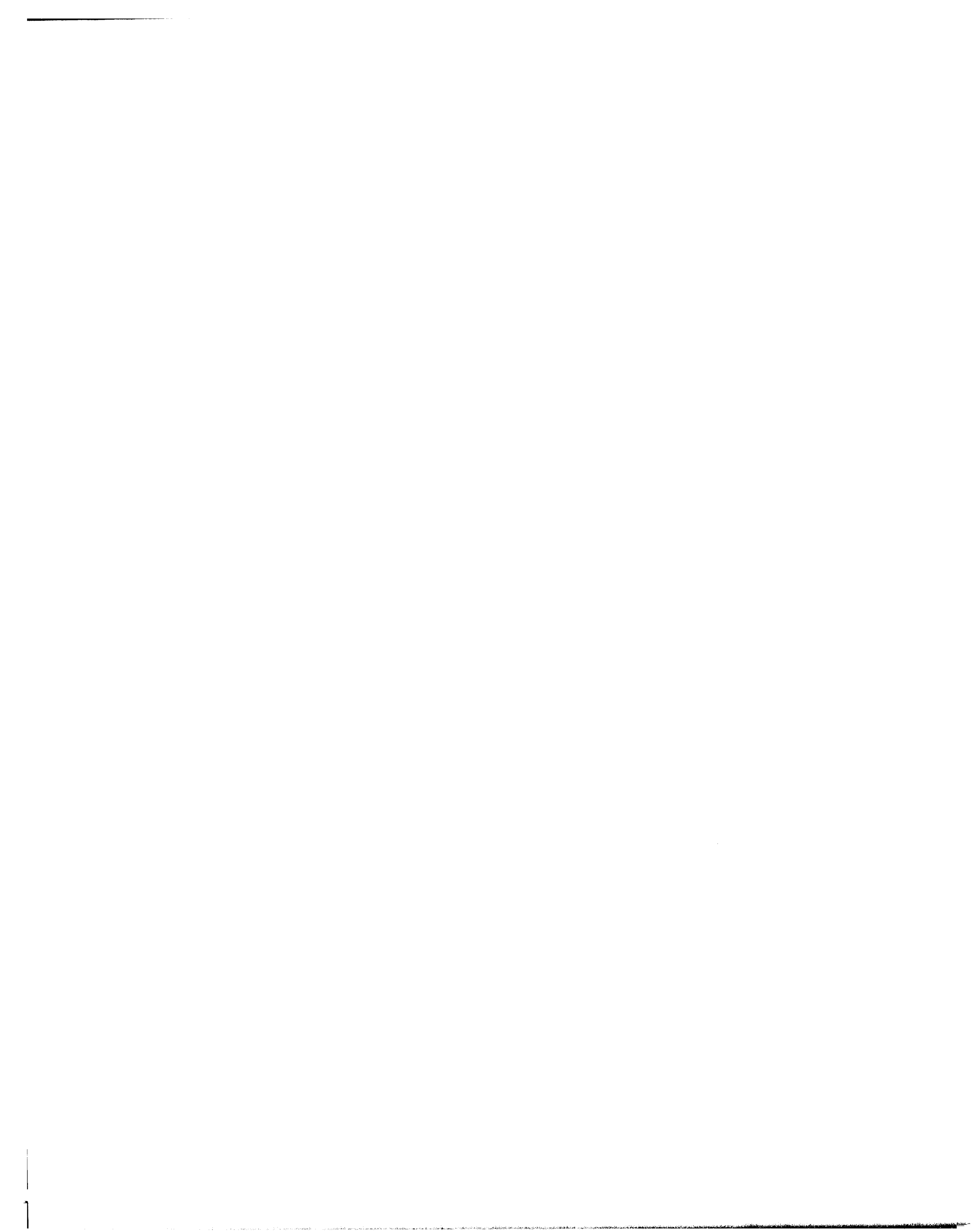

